FINNISH METEOROLOGICAL INSTITUTE

CONTRIBUTIONS

NO. 162

\title{
CHEMICAL CHARACTERISATION OF BOREAL FOREST AIR WITH CHROMATOGRAPHIC TECHNIQUES
}

\author{
Marja Hemmilä \\ Institute for Atmospheric and Earth System Research / Physics \\ Faculty of Science \\ University of Helsinki \\ Helsinki, Finland
}

Academic dissertation

To be presented, with the permission of the Faculty of Science of the University of Helsinki, for public criticism in auditorium A129,

A.I. Virtasen aukio 1, on March 27th, 2020, at 12 o'clock noon.

Finnish Meteorological Institute, Helsinki 2020 
Supervisors Docent Heidi Hellén, Ph.D.

Atmospheric Composition Research

Finnish Meteorological Institute

Professor Hannele Hakola, Ph.D.

Atmospheric Composition Research

Finnish Meteorological Institute

Professor Tuukka Petäjä, Ph.D.

Institute for Atmospheric and Earth System Research (INAR) / Physics

Faculty of Science

University of Helsinki

Reviewers Associate Professor Taina Yli-Juuti, Ph.D.

Department of Applied Physics

University of Eastern Finland, Finland

Professor Riikka Rinnan, Ph.D.

Department of Biology

University of Copenhagen, Denmark

Custos Professor Tuukka Petäjä, Ph.D.

Institute for Atmospheric and Earth System Research

University of Helsinki, Finland

Opponent Senior scientist Steffen Noe, Dr.rer.nat.

Institute of Agricultural and Environmental Sciences

Estonian University of Life Sciences, Estonia

ISBN 978-952-336-099-0 (paperback)

ISBN 978-952-336-100-3 (pdf)

ISSN 0782-6117

Edita Prima Oy

Helsinki 2020 


\section{Finnish Meteorological Institute}

(Erik Palménin aukio 1), P.O. Box 503

FIN-00101 Helsinki, Finland
Series title, number and report code of publication

Finnish Meteorological Institute

Contributions 162, FMI-CONT-162

Date March 2020

\begin{tabular}{ll}
\hline Author & Marja Sanni Hemmilä \\
ORCID iD & https://orcid.org/0000-0001-5714-2630
\end{tabular}

Title

Chemical Characterisation of Boreal Forest Air with Chromatographic Techniques

\section{Abstract}

Atmospheric aerosol particles are small, liquid or solid pieces that are floating in the air. They have a significant effect on air quality, human health and cloud formation. Sources of aerosols can be either primary or secondary, meaning that they can directly be emitted from the source to the air (e.g. sea salt, sand or pollen) or they can be formed from the precursor gases in the air. For example, sulphuric acid, ammonia, amines and oxidised organic vapours are gases that affect the nucleation process.

Biogenic Volatile Organic Compounds (VOCs) are gases that are emitted by e.g. boreal forest, and they affect secondary organic aerosol (SOA) population by contributing to the production of oxidised organic vapours that participate in the formation and growth of secondary aerosol particles. In this thesis, thermal desorption inlet gas chromatograph coupled with mass spectrometer (TD-GC-MS) was used to determine how monoterpenes, which are one sub-group of the BVOCs, are emitted from Scots pine and Norway spruce trees. It was discovered that individual trees emit different amounts of various monoterpenes, even when the trees belong to the same species. We concluded that the emissions depend on the chemotype of the trees, which is an inherited property of the individual tree.

Nitrogen containing gases, such as ammonia, amines and nitric acid can also take part in the aerosol formation and growth processes. Ammonia and amines stabilise sulphuric acid clusters, therefore helping the new aerosol particles to form. Another nitrogen contain gas, HONO, strongly affects atmospheric chemistry because it reacts with solar radiation and forms a $\mathrm{OH} \cdot$ radical, which is one of the main radicals in the atmosphere. We measured the seasonal and diurnal variation of ammonia, nitric acid and HONO in the boreal forest with an instrument of Measuring AeRosols and Gases in Ambient air (MARGA), which is an online ion chromatograph with a sampling system.

In this thesis, I developed a method for measuring aliphatic amines from the boreal forest air. I also coupled MARGA with a mass spectrometer (MARGA-MS) and used it to measure amine concentrations from the boreal forest air, observing the seasonal and diurnal variation of atmospheric amines. While I was measuring the atmospheric concentrations, the idea that amines could be emitted from the boreal forest floor and also melting snow and thawing ground, was born. To test this hypothesis, I measured with the MARGAMS connected to a dynamic flow through chamber emissions from the boreal forest floor. I found that the boreal forest floor is indeed a source of amines.

Publishing unit

Finnish Meteorological Institute, Atmospheric composition research

Classification (UDC) Keywords

502.3:613.15

Boreal forest, chromatography, VOCs, nitrogen compounds,

543.26 amines

ISSN and series title
0782-6117 Finnish Meteorological Institute

ISBN

Contributions

978-952-336-099-0 (paperback)

978-952-336-100-3 (pdf)

\begin{tabular}{lll}
\hline DOI & Language & Pages \\
10.35614/isbn.9789523361003 & English & 60
\end{tabular}


Julkaisija

\section{IImatieteen laitos}

(Erik Palménin aukio 1)

PL 503, 00101 Helsinki
Julkaisun sarja, numero ja raporttikoodi

Finnish Meteorological Institute Contributions 162,

FMI-CONT-162

Päiväys Maaliskuu 2020

\begin{tabular}{ll}
\hline Tekijä & Marja Sanni Hemmilä \\
ORCID iD & https://orcid.org/0000-0001-5714-2630
\end{tabular}

Nimeke

Pohjoisen metsäilman kemiallinen karakterisointi kromatografisilla tekniikoilla

Tiivistelmä

IImakehän aerosolihiukkaset ovat pieniä, nestemäisiä tai kiinteitä hippusia, jotka leijuvat ilmassa. Niillä on merkittävä vaikutus ilmanlaatuun, terveyteen ja pilvien muodostumiseen. Aerosolien lähteitä on sekä primäärisiä että sekundäärisiä, mikä tarkoittaa sitä että ne voivat joko suoraan emittoitua lähteestä ilmaan (kuten merisuola, hiekka tai siitepöly), tai ne voivat muodostua suoraan ilmakehän kaasuista. Esimerkiksi rikkihappo, ammoniakki, amiinit ja hapettuneet orgaaniset höyryt ovat kaasuja, jotka voivat vaikuttaa nukleaatioprosessiin.

Biogeeniset haihtuvat orgaaniset yhdisteet (BVOC) ovat kaasuja, jotka emittoituvat mm. pohjoisesta metsästä. Ne tuottavat hapettuneita orgaanisia höyryjä, jotka vaikuttavat sekundäärisien orgaanisien aerosolien muodostumiseen ja kasvuun. Tässä väitöskirjassa termodesorptio-kaasukromatografi-massaspektrometri laitteistoa (TD-GC-MS) käytettiin määrittämään BVOCien alaluokkaan kuuluvien monoterpeenien haihtumista männyistä ja kuusista. Havaittiin, että yksittäiset puut emittoivat erimääriä erilaisia monoterpeeneitä, vaikka ne kuuluisivat samaan lajiin. Johtopäätöksenä oli, että emissiot riippuvat puun kemotyypistä, joka on yksittäisen puun peritty ominaisuus.

Typpeä sisältävät kaasut kuten ammoniakki, amiinit ja typpihappo voivat myös ottaa osaa aerosolien muodostukseen ja kasvuun.Ammoniakki ja amiinit tasapainoittavat rikkihapporyppäitä auttaen aerosolihiukkasta syntymään. Eräs typpeä sisältävä kaasu, HONO, vaikuttaa vahvasti ilmakemiaan koska se reagoi auringon säteilyn kanssa tuottaen $\mathrm{OH}$ • radikaalin, joka on yksi tärkeimmistä radikaaleista ilmakehässä. Ammoniakin, typpihapon ja HONOn vuosi- ja vuorokausivaihtelua mitattiin pohjoisessa metsässä jatkuvatoimisella ionikromatografilla, joka myös ottaa näytteen itsenäisesti ilmasta (MARGA).

Tässä väitöskirjassa kehitettiin menetelmä mittaamaan alifaattisia amiineita pohjoisesta metsäilmasta. MARGA yhdistettiin massaspektrometriin (MARGA-MS), ja sitä käytettiin määrittämään pohjoisen metsäilman amiinipitoisuuksia, havainnoiden amiinipitoisuuksien vuosi- ja vuorokausivaihtelu. Pitoisuuksia mitatessa syntyi ajatus metsämaan sekä sulavan lumen ja maan mahdollisuudesta olla amiinien lähde metsäilmassa. Hypoteesi testattiin liittämällä MARGA-MS dynaamiseen kammioon ja mittaamalla amiini- ja guanidiiniemissioita metsämaasta. Tulokseksi saatiin, että metsämaa tosiaan on amiinien lähde.

Julkaisijayksikkö

IImatieteen laitos, IImakehän koostumuksen tutkimus

\begin{tabular}{ll}
\hline Luokitus (UDK) & Asiasanat \\
$502.3: 613.15$ & Pohjoinen metsä, kromatogafia, haihtuvat orgaaniset \\
543.26 & yhdisteet, typpiyhdisteet, amiinit \\
\hline
\end{tabular}

ISSN ja avainnimeke ISBN

0782-6117 Finnish Meteorological Institute

978-952-336-099-0 (paperback)

Contributions 978-952-336-100-3 (pdf)

DOI Kieli Sivumäärä

10.35614/isbn.9789523361003 Englanti 60




\section{Acknowledgements}

The research for this thesis was carried out in Atmospheric Composition Research Unit (IKO) of the Finnish Meteorological Institute (FMI) and in SMEAR II, Hyytiälä. I want to thank Research Professor Yrjö Viisanen, Director of Climate Research Programme Hannele Korhonen, Dr Heikki Lihavainen and Prof. Hannele Hakola, for providing excellent working facilities. I thank Prof. Riikka Rinnan and Assoc. Prof. Taina Yli-Juuti for reviewing my thesis. All the co-authors of the papers are also acknowledged.

I was 19 when I first came to FMI to work as a summer student, and I was lucky to meet great role models already then. I want to thank my supervisors from FMI, Docent Heidi Hellén and Prof. Hannele Hakola for all the things they have taught to me and all the support and discussions. It was your example that made me want to do PhD. I also want to thank my supervisor from the University of Helsinki, Prof. Tuukka Petäjä, for all the support he has gave me when I was needing it.

I want to thank Ulla and Anne, and earlier Anne-Mari for sharing the room in FMI. Ulla, Anne and Janne, thank you for sharing the knowledge and feelings towards MARGA. You know that we have the superpower to make it work again. Katriina, Mika, Arno and Simon, thank you for all our discussions, work related or not so much work related. I want to thank the colleagues and technical staff from Helsinki and Hyytiälä for all the help and support. For this thesis it was crucial, that someone took care of MARGA when I was in Helsinki and it was measuring in Hyytiälä. Thank you Matti, Reijo and Janne L. for looking after the instrument and all other technical support.

I met Jutta in Hyytiälä, when she was a summer worker and I needed someone to watch that I don't fell from the roof. I was so happy, when you started in FMI as a PhD student! Thank you for your friendship and all the peer support. I also want to thank rest of the HUPIpeople, Ana and Annemari, for organising all the fun for IKO with us. Also FMI Salsa is thanked for all the fun!

In the first laboratory course of chemistry studies I met Nina, and we have been friends ever since. Thank you for that, and also thank you for all the peer support you have given me, especially in the final months of this PhD-journey. Tuija, thank you for your support and for answering to my questions, science related or not so much science related. Also Jenni, thank you for being always so positive and encouraging. Thank you both for your friendship!

My other friends are also thanked for company and support, especially Emilia, who was also in the same first lab course, and Nelli, who has been my friend since we were $\sim 9$ years old. I also want to thank my parents, brothers and other relatives, who has always supported me and my choices. As a child, I did calculations with my father and tested new recipes with my mother, and I think that chemistry quite well combines these skills. I want to thank my children Lumi and Saarni for your patience, but also for forcing me to think something else than the thesis. The joy that bubbles from you makes me always happy. The greatest thank goes to the light of my life, my husband and the father of my children Verner, who always hated MARGA but loved me. 


\section{Table of contents}

\section{List of Publications}

List of Acronyms

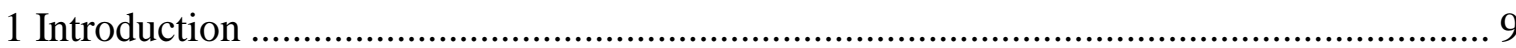

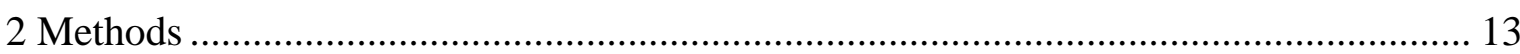

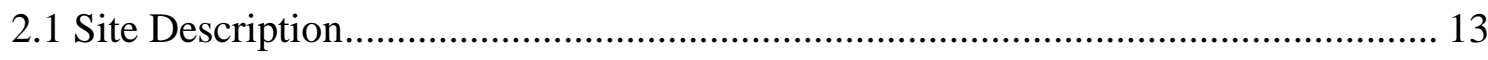

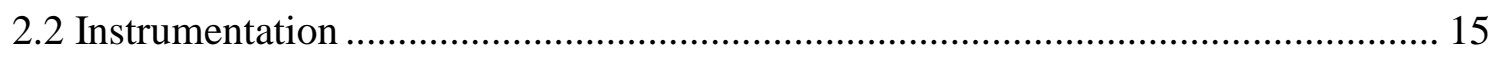

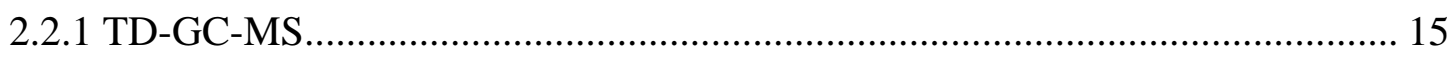

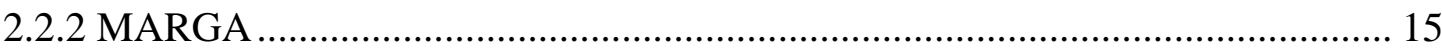

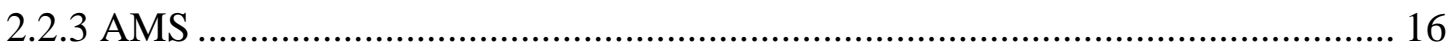

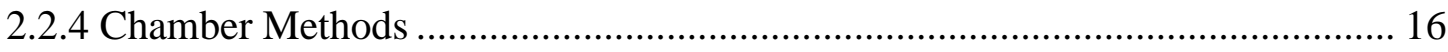

3 Chemotypes of Scots Pines and Norway Spruces ........................................................ 19

4 A New Method to Study Amine Concentrations from Ambient Air: MARGA-MS....... 21

5 Inorganic Nitrogen Containing Compounds in the Boreal Forest Atmosphere .............. 28

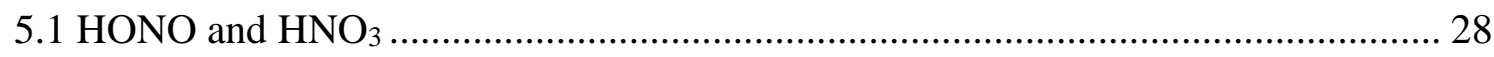

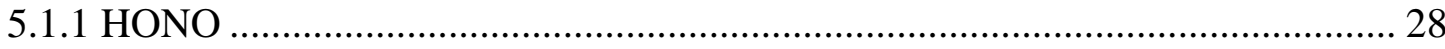

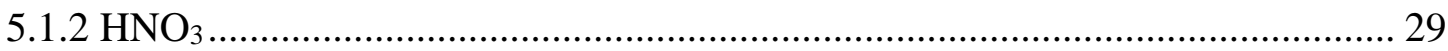

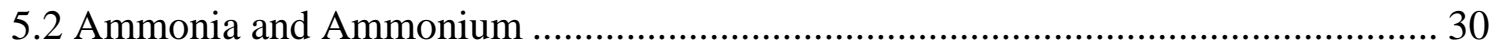

6 Amines in the Boreal Forest Ambient Air and Their Possible Sources .......................... 32

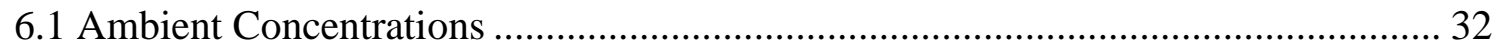

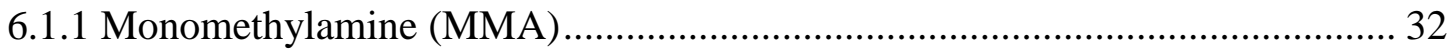

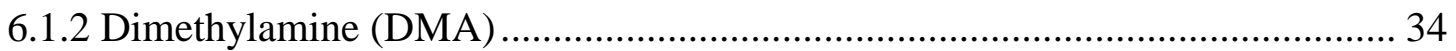

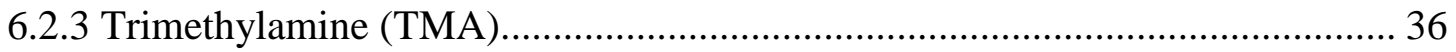

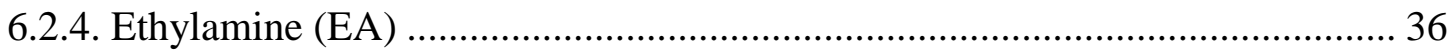

6.2 Amine Emissions from the Boreal Forest Floor .................................................... 38

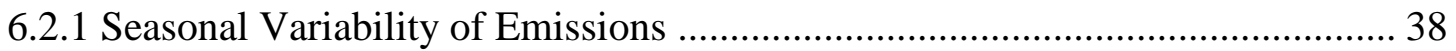

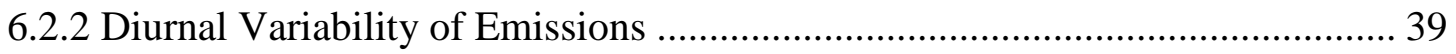

6.2.3 Effect of Environmental Parameters on the Emission Rates............................. 41

7 Review of Papers and Author's Contribution ................................................................ 43

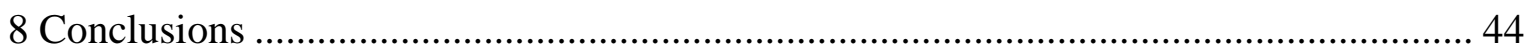

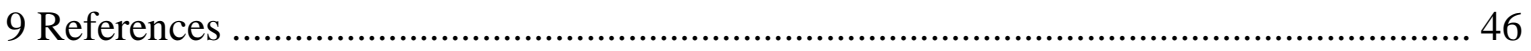




\section{List of Publications}

This thesis consists of an introductory section, followed by five research articles. Papers I, II, IV and $\mathbf{V}$ are reproduced here under Creative Commons Attribution 3.0. License. Paper III is reproduced with a permission from the Boreal Environment Research Board.

I Bäck, J., Aalto, J., Henriksson, M., Hakola, H., He., Q. and Boy, M.: Chemodiversity of a Scots pine stand and implications for terpene air concentrations, Biogeosci., 9, 689-702, doi: 10.519/bg-9-689-2012, 2012.

II Hakola, H., Tarvainen, V., Praplan, A. P., Jaars, K., Hemmilä, M., Kulmala, M., Bäck, J. and Hellén, H.: Terpenoid and carbonyl emissions from Norway spruce in Finland during the growing season, Atmos. Chem. Phys., 17, 3357-3370, https://doi.org/10.5194/acp-17-3357-2017, 2017

III Makkonen, U., Virkkula, A., Hellén, H., Hemmilä, M., Sund, J., Äijälä, M., Ehn, M., Junninen, H., Keronen, P., Petäjä, T., Worsnop, D. R., Kulmala, M., and Hakola, H.: Semi-continuous gas and inorganic aerosol measurements at a boreal forest site: seasonal and diurnal cycles of NH3, HONO and HNO3, Boreal Environ. Res., 19 (suppl. B), 311-328, 2014.

IV Hemmilä, M., Hellén, H., Virkkula, A., Makkonen, U., Praplan, A. P., Kontkanen J., Ahonen, L., Kulmala, M. and Hakola, H.: Amines in boreal forest air at SMEAR II station in Finland, Atmos. Chem. Phys., 18, 6367-6380, https://doi.org/10.5194/acp-18-6367-2018, 2018.

V Hemmilä, M., Makkonen, U., Virkkula, A., Panagiotopoulou, G., Aalto, J., Kulmala, M., Petäjä, T., Hakola, H., and Hellén, H.: Amine and guanidine emissions from a boreal forest floor, Atmos. Chem. Phys. Discuss., https://doi.org/10.5194/acp-20191157, in review, 2020. 


\section{List of Acronyms}

AMS Aerosol Mass Spectrometer

BA Butylamine

BVOC Biogenic Volatile Organic Compounds

DEA Diethylamine

DMA Dimethylamine

EA Ethylamine

MARGA an instrument for Measuring AeRosols and Gases from Ambient air

MMA Monomethylamine

MS Mass Spectrometer

MT Monoterpene

PA Propylamine

PTR-MS Proton Transfer Reaction Mass Spectrometer

SJAC Steam Jet Aerosol Collector

SMEAR Station for Measuring Forest Ecosystem-Atmosphere Relations

SOA Secondary Organic Aerosol

TMA Trimethylamine

VOC Volatile Organic Compounds

WRD Wet Rotating Denuder 


\section{Introduction}

Atmospheric aerosol particles are small, liquid or solid particles floating in the air. Aerosol number concentrations vary from a few hundred particles per cubic centimetre in very clean air like in Antarctica (Kyrö et al., 2013) to up to several hundred thousand particles in very polluted cities (Zhou et al., 2019). Aerosol particles affect air quality and cause changes in the visibility and also health problems, when inhaled. In 2016, small particulate matter of $2.5 \mu \mathrm{m}$ or less in diameter (PM2.5) was estimated to be involved in 4.2 million deaths globally (WHO, 2018). Climate change and global warming are one of the greatest challenges that humankind has faced (Karl and Trenberth, 2003). The massive increase in greenhouse gas emissions, such as $\mathrm{CO}_{2}$ and methane, is the largest reason driving climate change. The balance of climate depends on the incoming and outgoing energy described by radiative forcing. Greenhouse gases affect the Earth's energy balance by creating a positive forcing, when they absorb outgoing long wave radiation and trap the heat in the atmosphere. Most of the atmospheric aerosols have the opposite, cooling effects, because they can scatter solar radiation back to space, but also indirectly as they act as cloud condensation nuclei and affect the properties of clouds. The current estimate is that the aerosol particles have a net cooling effect i.e. negative forcing to the climate (IPCC 2013).

Aerosol particles can be formed via primary or secondary pathways. In other words, they can be emitted or released directly from the source into the air, or they can be formed in the atmosphere, descriptive for primary and secondary processes, respectively. Typical primary aerosols are salt from the ocean, sand, dust, pollen and products of burning processes. The secondary aerosols form from gas-phase precursors (Kulmala et al., 2014), such as sulphuric acid (Sihto et al., 2006), ammonia (Merikanto et al., 2007; Kirkby et al., 2011), amines (Silva et al., 2008; Loukonen et al., 2010; Zhao et al. 2010; Almeida et al., 2013,) and oxidized organic vapors (Ehn et al., 2012; Kulmala et al., 2013; Riccobono et al., 2013; Schobesberger et al., 2013). In specific cases, also atmospheric ions can play a role in secondary aerosol formation (Enghoff and Svensmark, 2008; Jokinen et al., 2018). It has been estimated that up to $50 \%$ of the particles can be formed via new particle formation (NPF) (Merikanto et al. 2009). NPF, which is also referred to as nucleation, is a frequent phenomenon and it is observed on approximately $30 \%$ of the days in the boreal forest measurement station in Hyytiälä, Finland (Dal Maso et al., 2005; Nieminen et al., 2014).

This thesis concentrates on two key groups of compounds that are pertinent to the secondary aerosol formation, namely Volatile Organic Compounds (VOCs) and amines. Both of these groups of compounds have both biogenic and anthropogenic sources (Kansal, 2009; Ge et al., 2011).

Biogenic volatile organic compounds (BVOCs) are a heterogeneous group, including the terpenoids (isoprene, mono- and sesquiterpenes), alkanes, alkenes, carbonyls, alcohols, esters, ethers, and acids, where the terpenoids, that are composed of characteristic $\mathrm{C}_{5}$-units, are the most remarkable compounds (Kesselmeier and Staudt, 1999). When BVOCs are released in the air, they have important functions in the nature, for example participating 
plant defence and communication. (Holopainen and Gershenzon, 2010; Holopainen and Blande, 2013). The concentrations of BVOCs are significant in rural areas, and the emissions of them from vegetation are estimated to exceed the respective anthropogenic ones by one order of magnitude (Guenther et al., 1995). BVOCs are important in atmospheric processes, because they e.g. influence aerosol formation and growth (Claeys et al., 2004; Kulmala et al., 2004; Tunved et al., 2006; Dal Maso et al., 2016). They also have an impact on the oxidative capacity of the troposphere (e.g. Atkinson and Arey, 2003; Lelieveld et al., 2008). Hence, BVOCs also affect the atmospheric reactivity significantly. The boreal forest forms an almost continuous belt around the Northern Hemisphere covering vast areas there (FAO, 2010). Different BVOCs are produced and emitted by boreal forests (Bourtsoukidis et al., 2014a, b; Paper I; Cojocariu et al., 2004; Grabmer et al., 2006; Hakola et al., 2001, 2006; Tarvainen et al., 2005; Yassaa et al., 2012), where the most common tree species are Scots pine, Norway spruce and silver and downy birch. Thus, the emissions of BVOCs from these areas play an important role in the atmospheric composition regionally and globally. The main monoterpenes in the ambient boreal forest air in Hyytiälä are $\alpha$ pinene, $\Delta^{3}$-carene, $\beta$-pinene and camphene in wintertime, and in summer also 1,8-cineol and sabinene are found (Hakola et al., 2009). Monoterpenes react with ozone and consequently produce stabilized Criegee intermediates, which further react with sulphur dioxide and produce sulphuric acid (Mauldin et al., 2012, Taipale et al., 2014, Bernt et al., 2012, Sarnela et al., 2018), which is an important precursor gas in the nucleation process (Kulmala et al. 2013).

Sulphuric acid is one of the key gas phase compounds for the secondary aerosol formation (e.g. Sipilä et al., 2010). Base compounds are needed to stabilize the acidic clusters in the initial steps of aerosol formation (e.g. Lehtipalo et al., 2016). Nitrogen containing gases are important to atmospheric processes and to the formation and growth of new aerosol particles. Particularly $\mathrm{NH}_{3}$ and $\mathrm{HNO}_{3}$ are gases that strongly affect the number and mass concentration of aerosol species, e.g. ammonium nitrate, ammonium sulphate, ammonium bisulphate and ammonium chloride (Finlayson-Pitts and Pitts, 2000, Kirkby et al. 2011). Ammonia $\left(\mathrm{NH}_{3}\right)$ is the most abundant gaseous base in the atmosphere and has a major role in neutralizing acids and in the formation of new particles (Merikanto et al., 2007, Kirkby et al. 2011, Kulmala et al. 2000). It can also react with the hydroxyl radical $(\mathrm{OH} \bullet)$ in the atmosphere, forming an amidogen radical $\left(\mathrm{NH}_{2}\right)$, which reacts further with nitrogen dioxide $\left(\mathrm{NO}_{2}\right)$ and forms nitrous oxide $\left(\mathrm{N}_{2} \mathrm{O}\right)$ (Park and Lin, 1997). Nitrous oxide is one of the main warming components in the atmosphere (Butterbach-Bahl 2011).

Amines have been suggested to be key compounds in the secondary aerosol formation by both models (Kurten et al., 2008; Paasonen et al., 2012) and laboratory tests (Angelino et al., 2001; Petäjä et al. 2011, Yu et al., 2012; Almeida et al., 2013; Glasoe et al., 2015). Amines are gaseous bases, whose general formula is $\mathrm{NR}_{3}$, where $\mathrm{R}$ denotes hydrogen or an alkyl or aryl group. Gas-phase amines cluster efficiently with atmospheric acid clusters (such as sulfuric acid, Kurtén et al., 2011) and therefore participate in neutralisation reactions in the atmosphere, making it hard to detect their free gas-phase atmospheric concentrations. 
Globally, the main known anthropogenic amine sources are animal husbandry, industry and composting processes, whereas natural sources are assumed to be the oceans, biomass burning, the vegetation and soil (Ge et al., 2011; Sintermann et al., 2014). The source of the low weight amines in the soils may be the degradation of organic $\mathrm{N}$ compounds, especially carboxylation of amino acids (Yan et al., 1996). In aerobic conditions, proteins, carnitine and choline in the soil can be degraded to trimethylamine and further to dimethyl- and methylamines (Rappert and Müller, 2005). From the soil, amines can enter the atmosphere via volatilization (Ge et al., 2011).

However, direct flux measurements of alkylamines are difficult to perform and they are very rare (Sintermann and Neftel, 2015), due to the high reactivity of the amines and the lack of suitable and quantified measurement techniques for the gas-phase amines. One complication is, for example, that amines are "sticky", so they are easily lost in the inlets of instruments. Kieloaho et al. (2017) estimated the magnitudes of soil-atmosphere fluxes of dimethylamine (DMA) and diethylamine (DEA) using a gradient-diffusion approximation based on measured concentrations in the soil solution and in the canopy air space. They found that the boreal forest soil is a possible source of DMA $\left(170 \pm 51 \mathrm{nmol} \mathrm{m}^{-2} \mathrm{day}^{-1}\right)$ and a sink of DEA $\left(-1.2 \pm 1.2 \mathrm{nmol} \mathrm{m}^{-2}\right.$ day $\left.^{-1}\right)$.

Other strong bases in addition to ammonia or amines can also be relevant to aerosol formation. A good candidate can be a strong organobase, guanidine, which is a catabolite of arginine and has been found in urine (Marescau et al., 1992; Van Pilsum et al., 1956). Arginine has been detected in a boreal forest in Alaska, USA (Werdin-Pfisterer et al., 2009). In a recent model study, the role of guanidine was examined in a sulphuric acid-driven newparticle formation (Myllys et al., 2018). They concluded that more than a 2000-fold concentration of dimethylamine is needed to yield as efficient particle formation as in the case of guanidine, and thus guanidine was included in the study.

In this thesis, I developed and used a combination of chromatographic and mass spectrometric methods to characterise the chemical composition of the boreal forest atmosphere. Special interest was on biogenic volatile organic compounds, ammonia, amines and guanidine in the gas phase. Fig. 1 summarises the different compounds studied in this thesis, and from where the field studies were conducted.

In summary, the aims of this thesis are:

1) to fill the knowledge gap related to quantification of BVOC-emissions from Scots Pine (Paper I) and Norway Spruce (Paper II) and specifically to discover how the emissions vary between individual trees of the same species,

2) to develop and to quantify a method for in situ, on-line gas-phase amine measurements (Paper IV),

3) to understand the processes governing the concentration variations of gas-phase amine (Paper IV) and inorganic nitrogen compounds $\left(\mathrm{NH}_{3}\right.$ and $\mathrm{NH}_{4}{ }^{+}, \mathrm{HONO}$, $\left.\mathrm{HNO}_{3}\right)($ Paper III) and their concentrations in the boreal forest air,

4) to determine amine and guanidine sources from the boreal forest soil (Paper V). 


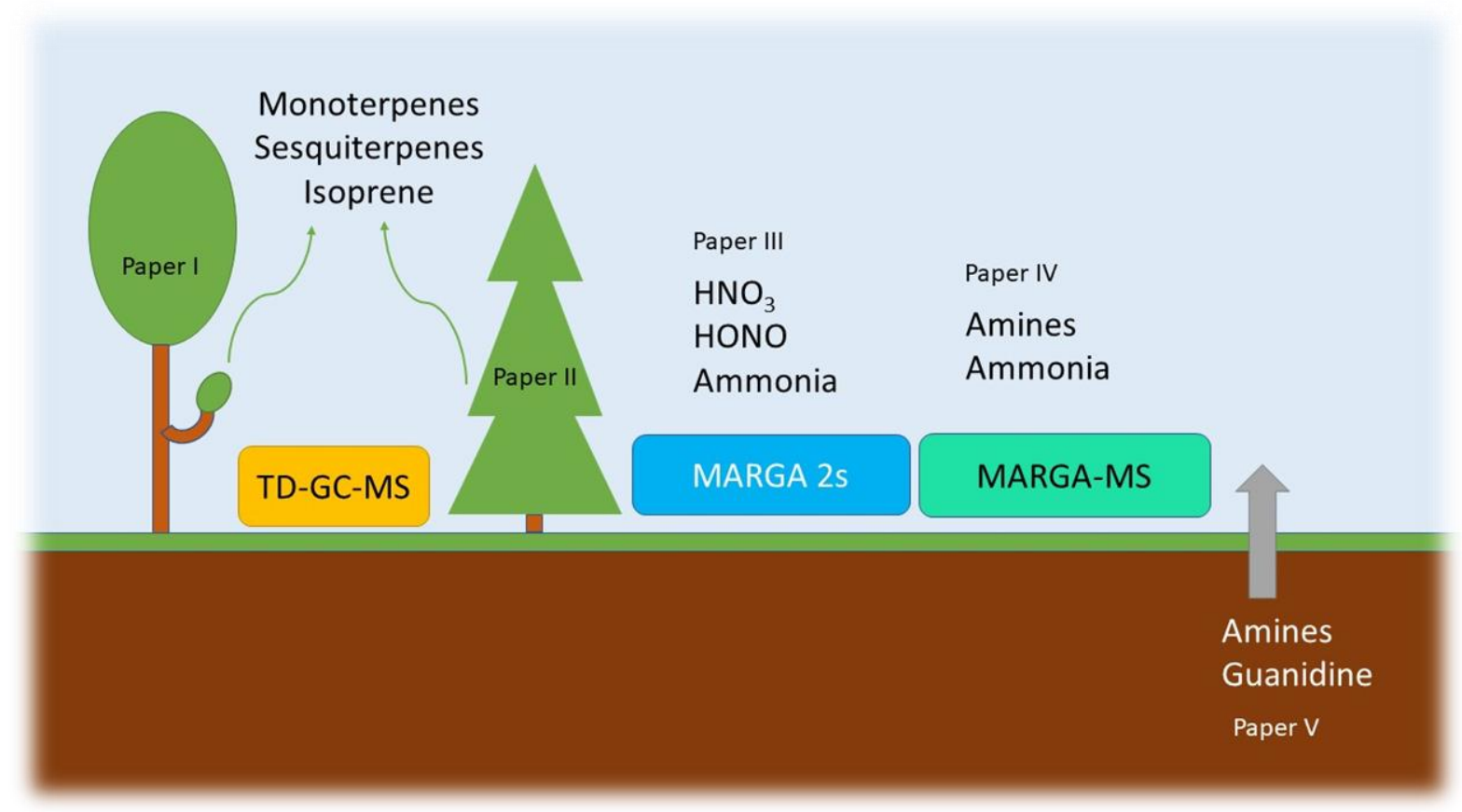

Figure 1. A schematic picture of the instruments, measurement types and environments, and measured the compounds explored in Papers $\mathbf{I}-\mathbf{V}$. 


\section{Methods}

\subsection{Site Description}

All the measurements presented in Papers II - V were conducted at SMEAR II (Station for Measuring forest Ecosystem - Atmospheric Relations, Hari and Kulmala, 2005) site in Hyytiälä, Southern Finland $\left(61^{\circ} \mathrm{N}, 24^{\circ} \mathrm{E}, 180 \mathrm{~m}\right.$ a.s.l.), about $60 \mathrm{~km}$ North East of the city of Tampere. The SMEAR II station has been operational since 1995. The forest stand at the SMEAR II station is approximately 60 years old surrounded by trees with an average height of $19 \mathrm{~m}$. The governing species is Scots pine (Pinus sylvestris) (>60\% of the trees). Some Norway spruce (Picea abies (L) H. Karst), aspen (Populus tremula L.) and birch (Betula L. spp.) grow in the forest around the site. The most common vascular plant species at ground level are lingonberry (Vaccinium vitis-idaea L.), bilberry (Vaccinium myrtillus L.), wavy hair-grass (Deschampsia flexuosa (L.)) and heather (Calluna vulgaris (L.) Hull.), and most common mosses are Schreber's big stem moss (Pleurozium schreberi (Brid.) Mitt.) and dicranum moss (Dicranum Hedw. sp.) (Ilvesniemi et al, 2009). The soil in the stand is mainly podzolic and characterized by a thin humus layer and a low nitrogen level.

For the in situ studies, the instruments (Papers II - V) were placed in a container owned by Finnish Meteorological Institute (FMI, Fig. 2), and it was kept at a constant temperature of $20{ }^{\circ} \mathrm{C}$. The container was located in a small clearing about $5 \mathrm{~m}$ from the nearest trees. In Paper I, the branch samples were cut from different trees (Fig. 3), and analysed later in the laboratory. They were stored in cold $\left(<+4{ }^{\circ} \mathrm{C}\right)$ in plastic bags, and the emissions from the branches were measured immediately after they were transported into the laboratory, not more than 10 days from sampling. 


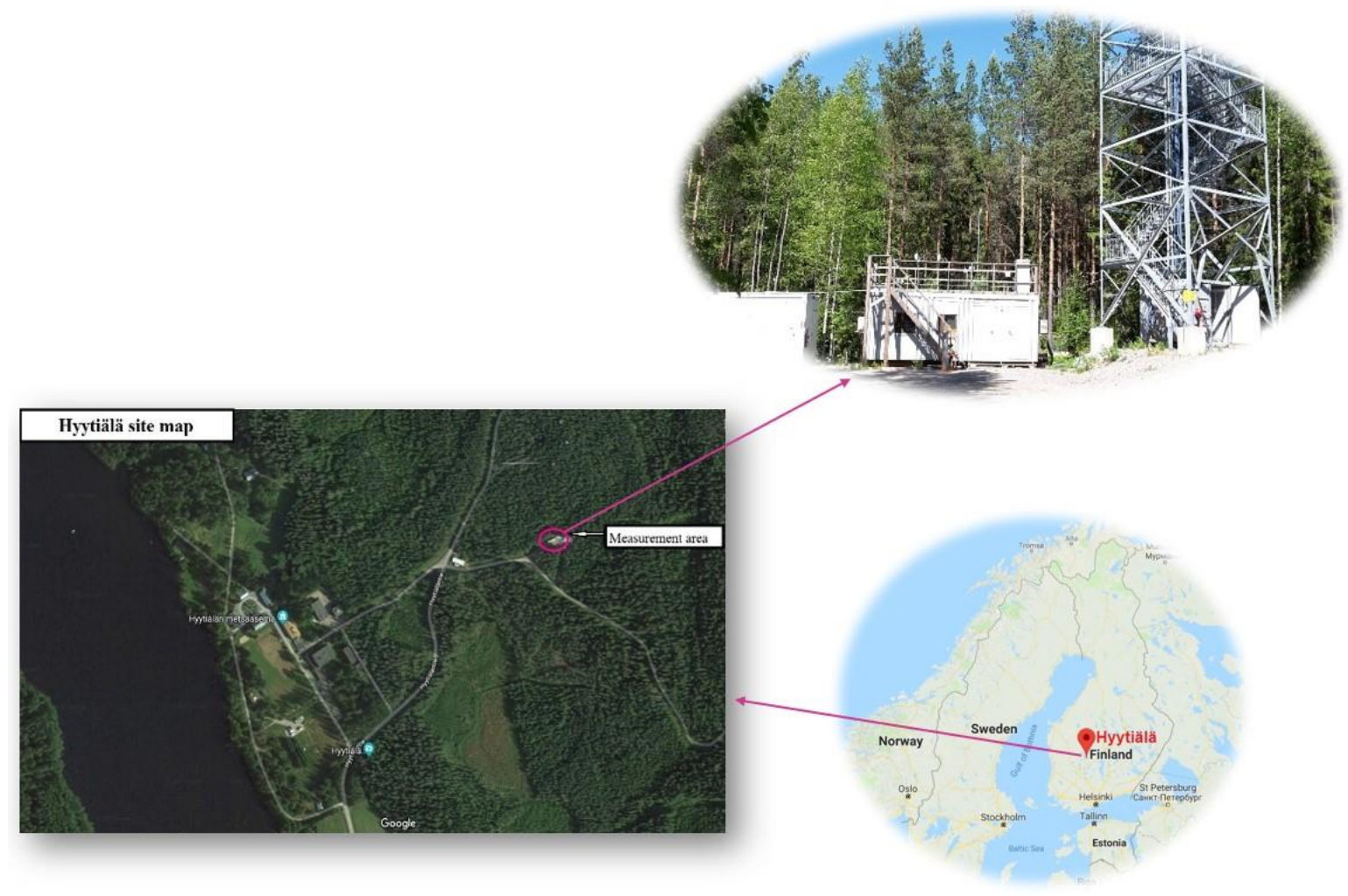

Figure 2. Hyytiälä site map and the location of the FMI container.
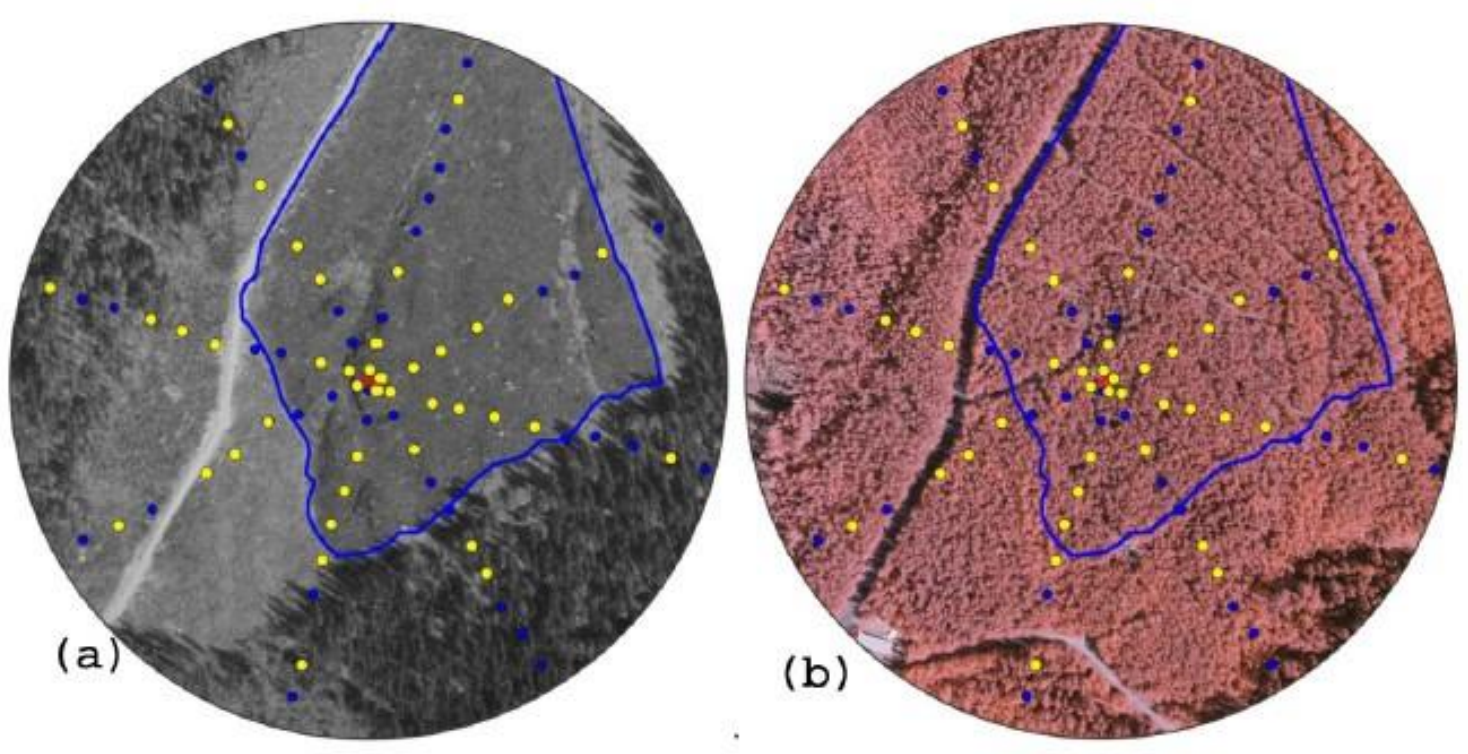

Figure 3. Aerial photographs of the Paper I branch sample area. The diameter of the circle is $400 \mathrm{~m}$ and it is centred at the SMEAR II mast (red dot). The sampling grid is marked with blue (no sample) and yellow (sampled) circles. (a) SMEAR II stand (marked with a blue line) and neighbouring stands in 1962; (b) The same stands in 1997. Figure adopted from Paper I. 


\subsection{Instrumentation}

\subsubsection{TD-GC-MS}

Thermal desorption - gas chromatography - mass spectrometry (TD-GC-MS) is a widely used method to determine VOCs from the air. In this work, TD-GC-MS was chosen since it allows differentiation between mono- and sesquiterpenes with gas chromatography. When using only the mass spectrometric methods such as a proton transfer reaction mass spectrometer (PTR-MS, Hansel et al., 1999), all the compounds with the same molecular mass are seen as one peak as the typical mass resolution does not allow peak separation based on differences in the molecular structures only.

In this work, atmospheric samples were collected onto adsorbent tubes actively with a pump. In the TD unit, the collection tubes are heated and the collected VOCs are evaporated into a carrier gas. The sample is subsequently concentrated in a cold trap. After that the cold trap is rapidly heated and the analytes continue their way to the GC separation followed by MS detection.

In Paper II, we used in situ online-TD-GC-MS (Perkin Elmer ATD-400 connected to HP 5890 coupled with HP 5972), in combination with a sampling system directly sampling from the coldtrap. In 2011 the atmospheric samples were collected onto Tenax TA sampling tubes whereas Tenax TA/Carbopack-B were in use in 2014 and 2015. In Paper I, the analysis was done in the laboratory with a different online-TD-GC-MS (Perkin Elmer TurboMatrix 650 ATD connected to Perkin Elmer Clarus 600), and the samples were collected with a pump to Tenax TA/ Carbopack-B absorbent tubes.

\subsubsection{MARGA}

The instrument for Measuring AeRosols and Gases from Ambient air (ten Brink et al., 2007) was developed to measure the concentration and chemical composition of water-soluble compounds from the atmospheric aerosol particles and trace gases. The MARGA instrument consist of one or two sample boxes, a detector box and a pump box. In the sample box (Fig. 4), there is a wet rotating denuder (WRD, Wyers et al. 1993) and a Steam Jet Aerosol Collector (SJAC, Slanina et al. 2001). The wet rotating denuder includes two glass tubes between which there is water. When the WRD rotates, the water forms a thin layer to the surfaces of glass tubes. When the air flow $\left(1 \mathrm{~m}^{3} \mathrm{~h}^{-1}\right)$ goes through, the aerosol particles remain within the flow but the gases diffuse into the water surface and are trapped.

The aerosol particles are collected with the Steam Jet Aerosol Collector (SJAC). In SJAC, ambient temperature air flow with aerosol particles is brought into contact with hot steam. This results in a supersaturation with respect to water vapour and therefore water starts to condense to the surface of the particles. The growing droplets drop to the bottom of the SJAC, from where they are sampled to the IC analysis with a conductivity detector. MARGA collects one sample per hour and analyses it during the next hour. The IC connection is performed utilizing sample syringes. From the denuder and from the SJAC, the sample is collected to sample syringes, which are one pair per sample box. From the 
syringes, the sample is mixed with an internal standard solution (ISTD, LiBr), and the formed solution continues to the IC-analysis.

In this thesis, MARGA 2s with two sample boxes was used in Paper III to measure inorganic nitrogen compounds at the SMEAR II station. MARGA 1s with one sample box was used in Papers IV and V, coupled with a mass spectrometer to measure organic nitrogen compounds.

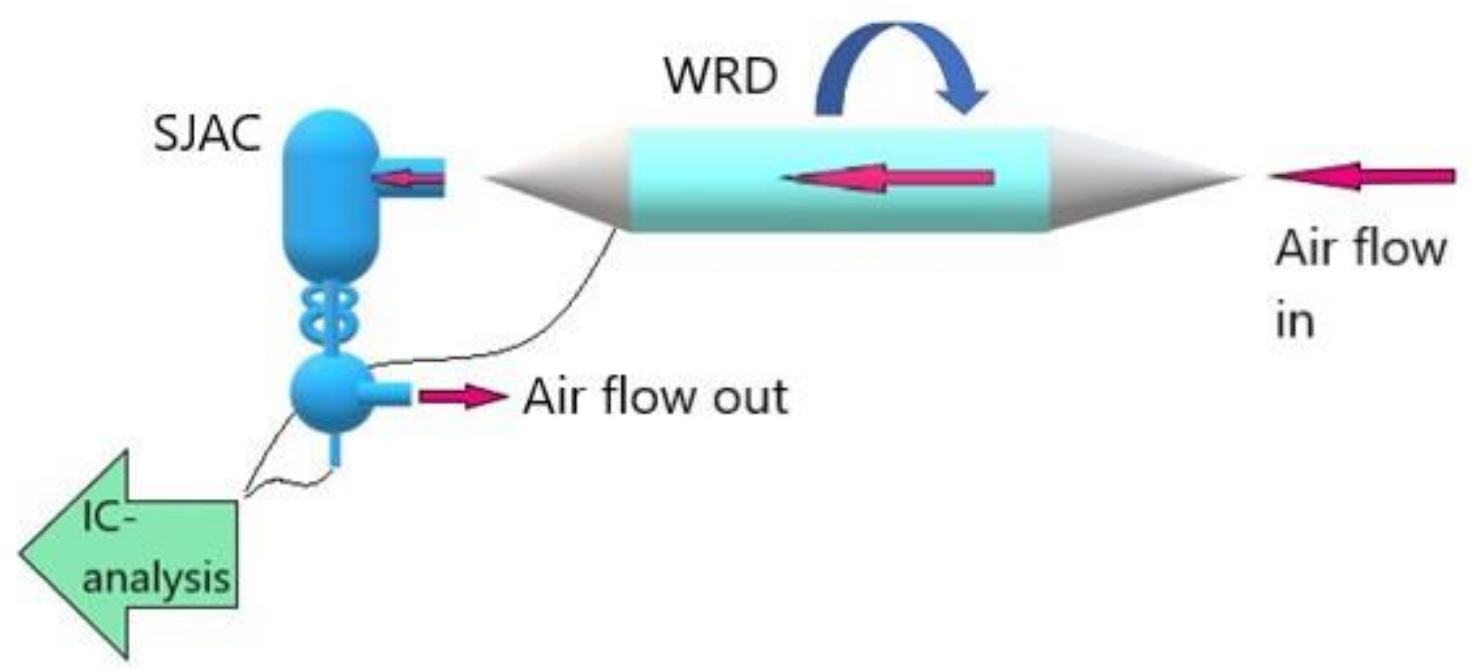

Figure 4. A schematic picture of the MARGAs sample box.

\subsubsection{AMS}

The Aerosol Mass Spectrometer (AMS, Aerodyne Inc. Billerica, MA, USA, REF) measures the chemical composition of aerosol particles directly and quantitatively by using time-offlight mass spectrometry (TOF-MS) (Jayne et al., 2000, Jimenez et al., 2003). In the AMS, aerosol particles between $40-600 \mathrm{~nm}$ size are sampled from the atmosphere and then brought into the instrument. Inside the aerosol particles are focused with an aerodynamic lens (Liu et al., 2007) into a beam, and thermal vaporisation element at the temperature $600^{\circ} \mathrm{C}$ is used to flash-vaporise all non-refractory compounds in the sample. After that, an electron impact ionisation (EI) source with a fixed energy of $70 \mathrm{eV}$ ionises the vaporised sample. Finally, TOF-MS produces a mass spectrum of the compounds in the sampled aerosols and the remaining carrier gas. In Paper III, we used AMS with a compact time-of-flight (C-TOF) mass analyser, described by Drewnick et al. (2005). The inlet cut-off size was $1 \mu \mathrm{m}$. This provided a comparison data set about the chemical composition of the aerosols that was compared to the MARGA 2s PM2.5 results (Paper III).

\subsubsection{Chamber Methods}

Chamber methods are widely used for both branch (e.g. Kempf et al., 1996; Hakola et al., 2012; Paper II) and soil (e.g. Hellén et al., 2006; Aaltonen et al., 2011; Peñuelas et al., 2014; Mäki et al., 2017) VOC emission measurements. Also ammonia emissions have been 
measured with the chamber method (e.g. David et al., 2009). Two methods are commonly used to measure soil VOC fluxes: static and dynamic enclosures (Peñuelas et al., 2014). The chamber technique is popular probably, because it is suitable for all types of terrain, and because of its specificity for the soils (Peñuelas et al., 2014).

In Papers II and V, a dynamic flow-through chamber method was used. In the dynamic chamber method, a clean air flow is directed into the chamber and then a sample flow from the chamber is directed to a measurement instrument. The flow through the chamber is higher than the sample flow, to prevent the air outside of the chamber from distorting the results.

With the chamber method, the emission of a compound from an object inside the chamber, can be determined by the difference between the concentrations of the compound in the outgoing and in-going air. In Paper II and V, we determined the emission rates (E) and they were calculated by using Eq. 1:

$E=\frac{\left(C_{2}-C_{1}\right) * F_{i n}}{X}$

where $\mathrm{C}_{2}$ is the concentration in the out-going air $\left(\mathrm{ng} \mathrm{m}^{-3}\right), \mathrm{C}_{1}$ is the concentration in the incoming air $\left(\mathrm{ng} \mathrm{m}^{-3}\right), \mathrm{F}_{\text {in }}$ is the flow into the chamber $\left(\mathrm{m}^{3} \mathrm{~h}^{-1}\right)$ and $\mathrm{X}$ is a descriptive value of the process that allows up-scaling of the results. In Paper II, factor X was the dry weight of the biomass $(\mathrm{g})$, which was determined by drying the needles and shoot from the enclosure at $75^{\circ} \mathrm{C}$ for $24 \mathrm{~h}$ after the sampling date. In Paper V, X was the enclosed forest floor surface area $\left(\mathrm{m}^{2}\right)$.

\subsubsection{Chamber Method for Amine Measurements from the Forest Floor}

The chamber material plays a role in the dynamic flow-through chambers as the sample air interacts with the chamber walls. For an optimized chamber, the losses to the chamber walls needs to be minimized. This can be done with specific material choices. In this work, different chamber materials for amine measurements with MARGA 2s were tested in the laboratory (Hemmilä, 2013). The materials were stainless steel, fluorinated ethylene propylene (FEP) and polymethylmethacrylate (PMMA). When we tested the chambers, we first measured their blank-values without feeding amines in the chamber, and noticed that the blank value for the stainless-steel chamber was too high. It was higher than the expected amine concentration in the boreal forest. In further tests, we noticed that the FEP-chamber was also not suitable, because amines were lost to the surfaces. The best chamber material was PMMA even though the recovery rate for dimethyl amine (DMA) was only around 25\%. During the chamber material tests, we had a 12-meter long, heated FEP-inlet tubing from the chamber to the instrument. The inlet was heated to prevent amines from sticking on the surfaces. During the time of real measurements, the same 12-meter inlet was used.

In Paper V, we determined emission rates of amines and guanidine from the boreal forest floor with the optimised chamber setup. Initially the chamber was placed on the snow, but after the snow melted in April, the chamber was placed on a stainless steel collar (Fig. 5). The amine and guanidine emission measurements were conducted every month from March to September 2018 with the MARGA-MS, for about one week at a time. 

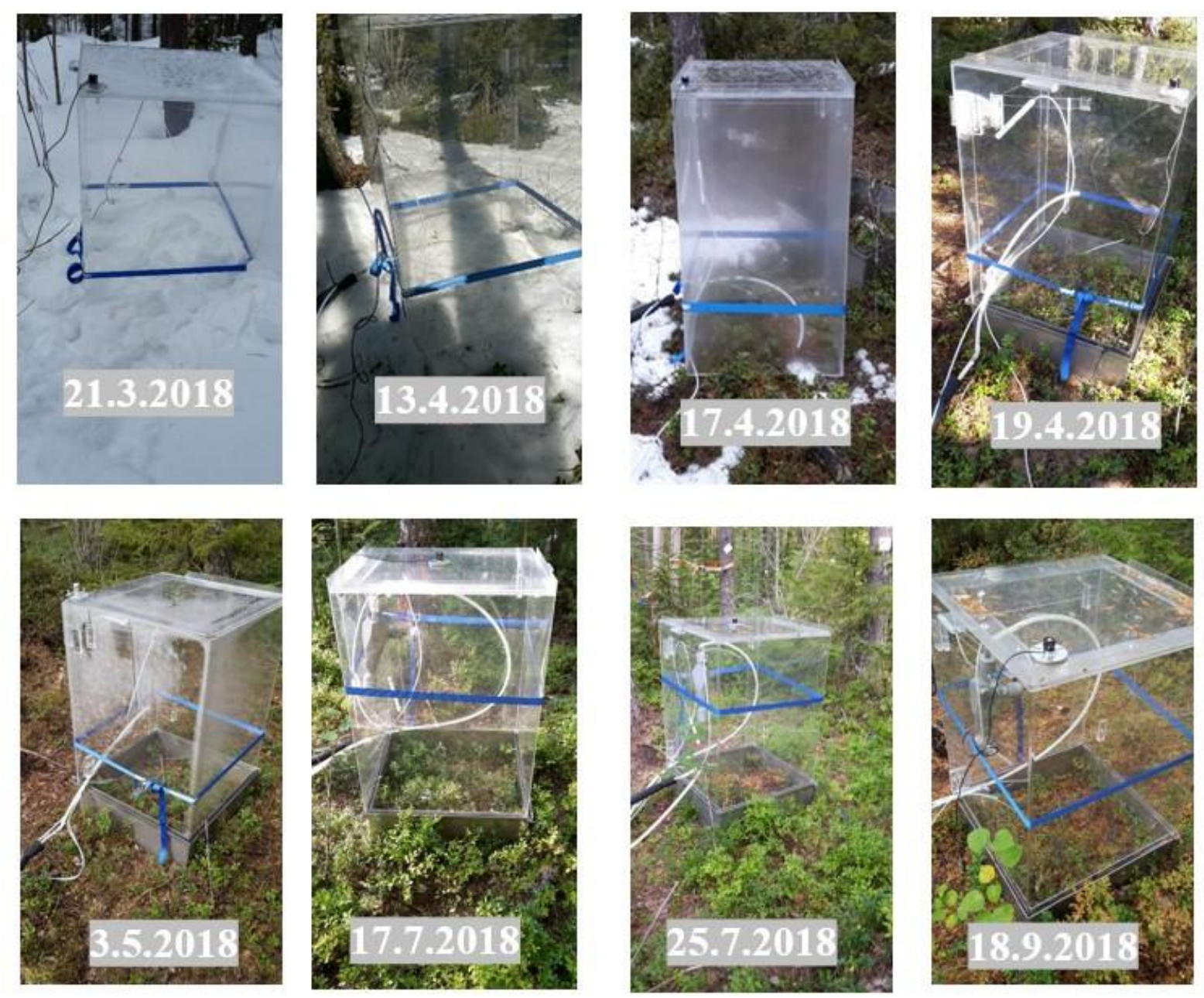

Figure 5. The PMMA-chamber in different measurement periods in March, April, May, July and September (Paper V). The snow melted between April $13^{\text {th }}$ and April $17^{\text {th }}, 2018$, and chamber was placed on a stainless steel collar. 


\section{Chemotypes of Scots Pines and Norway Spruces}

Mono- and sesquiterpenes are among the most important volatile organic compounds emitted from the boreal forest, and they form a major proportion of the conifer oleoresin (Fäldt et al., 2001). Individual VOCs differ in their atmospheric lifetime and reactivity. Hence, it is important to know the composition of the emission blend for understanding the atmospheric chemistry and its consequences. In Papers I and II, the chemotypes of Scots pines $(n=40)$ and Norway spruces $(n=6)$ were measured from the Hyytiälä stand.

A significant proportion (20\%) of the pine population was characterized as high $\Delta^{3}$-carene emitters (Fig. 6) whereas $37.5 \%$ emitted mostly $\alpha$ - and $\beta$-pinene, and the rest of the trees $(42.5 \%)$ emitted $\Delta^{3}$-carene and $\alpha$-pinene at almost equal proportions. Interspecies diversity has earlier been characterized from essential oils in plant tissues and cortical oleoresin, where it may be related to resistance towards herbivory, pathogens or some other stresses (Sjöldin et al., 2000; Maciag et al., 2007). In Paper I it was shown that similar diversity can also be seen in terpene emissions from the trees. In individual Scots pines, $\Delta^{3}$-carene was clearly the compound that made the difference between the emission blends. This finding is in accordance with previous studies on the oleoresin composition by e.g. Hiltunen (1975), Yadzani et al. (1985) and Orav et al. (1996). As seen in Fig. 6, some trees did not emit $\Delta^{3}$ carene at all. The grouping into high and low $\Delta^{3}$-carene chemotype trees suggested a strong monogenic control of the production of $\Delta^{3}$-carene in pine needles, which was already inferred by Hiltunen et al. (1975).

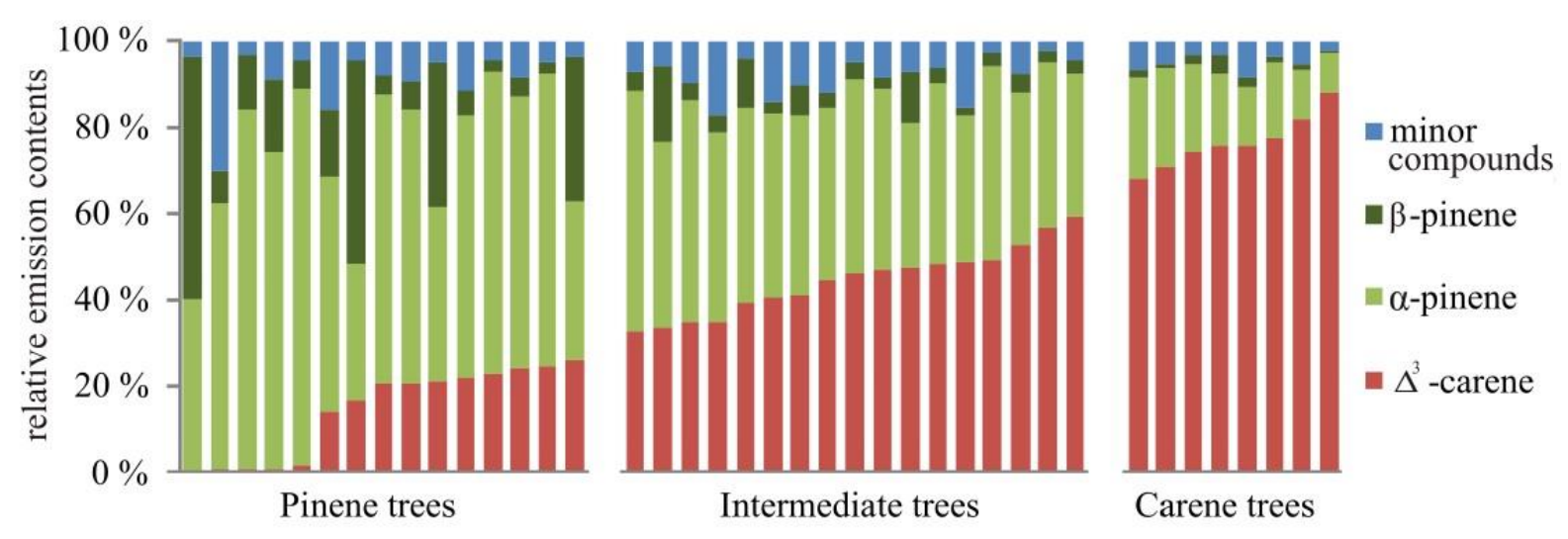

Figure 6. The chemodiversity of 40 individual Scots pines in summer 2009. Figure adapted from Paper I.

In June 2014 a qualitative analysis of six different Norway spruces which were growing in the same area, was conducted. The aim of this work was to find out how much variability there was between the spruce trees in their monoterpene emission patterns (Paper II). Unlike the pines, the spruces did not emit significant amounts of $\Delta^{3}$-carene. Instead, terpinolene was one of the main monoterpenes emitted by four of the trees (Fig. 7). However, in the emission spectrum of one of the trees terpinolene constituted only $3 \%$ of the emitted VOCs. Also limonene and camphene emissions varied between the spruce trees, 
from a few percent to about a third of the total monoterpene emissions. $\alpha$ - and $\beta$-pinenes were emitted in a rather similar proportion in every tree, although $\beta$-pinene emissions were generally low.

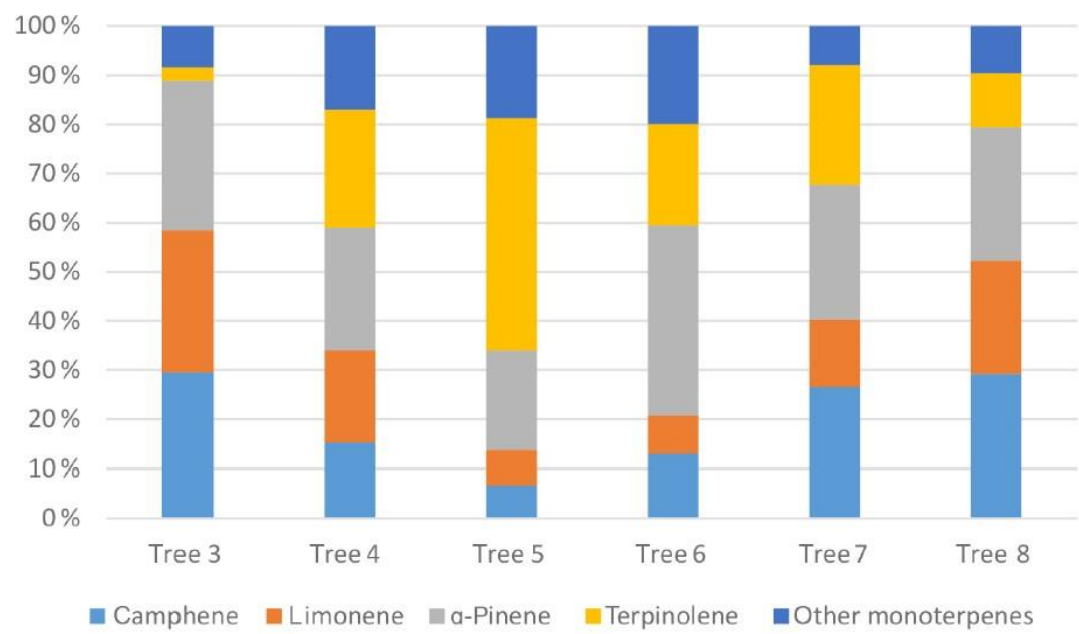

Figure 7. The chemodiversity of six different Norway spruce individuals on 24 June 2014. Adapted from Paper II.

Speciated monoterpene emission measurements in field conditions are often made with branch enclosures (e.g. Staudt et al., 1997; Tarvainen et al., 2005; Holzke et al., 2006), and the number of replicate trees are often very limited. This is due to the laborious processes related to the sampling and analysis procedures. The plant emissions are almost always composed of several compounds (e.g. Hakola et al., 1998; Cojocariu et al., 2004; Haapanala et al., 2009; Rinne et al., 2009; Paper I; Bourtsoukidis et al., 2014a; Paper II; Cappellin et al., 2017), and Papers I and II showed that both the pines and the spruces have different chemotypes with specific and individual chemical emission fingerprints. These results indicate that both species-specific measurements but also intra-species variability needs to be taken into account, particularly when considering the variable compound specific physico-chemical properties (Copolovici and Niinemets, 2005). Currently, air chemistry models very often use results from measurements of only a few branches (Guenther et al., 2012; Messina et al., 2016) or consider only one compound, typically $\alpha$-pinene, to represent all the monoterpenes from the vegetation (Friedman and Farmer, 2018). This can lead to biased results e.g. when predicting the emission rates from the vegetation and the resulting atmospheric concentrations. This hinders the use of the model results in e.g. understanding the atmospheric reactivity or connecting the VOCs to the secondary aerosol production (Kanakidou et al., 2005). Overall for a more comprehensive picture, Papers I and II showed, that ecosystem scale flux measurements are more representative than the branchscale measurements, and for the regional air chemistry models averaging over larger spatial scales could be more descriptive. However, branch scale measurements are needed, since they provide data on the emission factors of more reactive compounds whose fluxes cannot be measured. 


\section{A New Method to Study Amine Concentrations from Ambient Air: MARGA-MS}

Gas-phase amine concentrations can be measured in many ways, both with offline (e.g. filter sampling with High Performance Liquid Chromatography coupled with Mass Spectrometry HPLC-MS or GC-MS) techniques and with online (e.g. Chemical Ionization Mass Spectrometer CIMS, Chemical Ionization Atmospheric Pressure interface Time-Of-Flight CI-APi-TOF) instruments. The different techniques are summarized in Table 1 and Table 2 for the offline and online methods, respectively. The main obstacle in the amine measurements arises from very low ambient concentrations. In Paper IV we developed a method to sample and analyse atmospheric amines with MARGA-MS (Fig. 8). MARGA 1s with one sample box was coupled with an electrospray ionization quadrupole mass spectrometer (Shimadzu LCMS-2020; Shimadzu Corporation, Kyoto, Japan). Earlier, we had measured amines only with MARGA with a conductivity detector, but the detection limits were too high for ambient measurements. The retention times of MARGA-MS for monomethylamine (MMA), dimethylamine (DMA), trimethylamine (TMA), ethylamine (EA), diethylamine (DEA), propylamine (PA) and butylamine (BA) and the for the whole mixture are presented in Fig. 9.

Paper III was the first time MARGA was used in the boreal forest environment. During the time of the measurements, it was still a new instrument in Finland, and had only been used for one study in Finnish urban environment (Makkonen et al., 2012). In Paper III the results from MARGA was compared with the chemical composition of aerosol particles determined with the AMS and traditional filter measurements. Overall, the agreement was good, and $\mathrm{R}^{2}$ was in most of the cases higher than 0.8. Only $\mathrm{NO}_{3}{ }^{-}$comparison between MARGA and AMS was not acceptable, with $\mathrm{R}^{2}$ of only 0.07 . In the same measurement period, the nitrate concentrations measured with MARGA were in a good agreement with the EMEP filter data $\left(\mathrm{R}^{2}=0.87\right.$ and 0.93 for $\mathrm{PM}_{2.5}$ and $\mathrm{PM}_{10}$, respectively). One of the conclusions of Paper III was that MARGA could replace the traditional filter methods in background sites, if a concentration column would be used for cations. Without one, the concentrations in the ambient forest air are too low to be detected with MARGA. However, in Paper IV, we noticed that keeping the MARGA up and running actually needs a lot of maintenance work. On the other hand, significantly shorter sampling time acquired with the MARGA improved the temporal resolution of the observations but this comes together with the higher maintenance costs. 
Table 1. Offline methods for measuring atmospheric amine concentrations.

\begin{tabular}{|c|c|c|c|c|c|}
\hline \multicolumn{6}{|c|}{ Offline methods } \\
\hline $\begin{array}{l}\text { Analysis } \\
\text { method }\end{array}$ & $\begin{array}{l}\text { Sample } \\
\text { collection }\end{array}$ & $\begin{array}{l}\text { Sampling } \\
\text { time }\end{array}$ & $\begin{array}{l}\text { Amine } \\
\text { phase }\end{array}$ & Amines & Reference \\
\hline HPLC-MS & $\begin{array}{l}\text { Phosphoric-acid- } \\
\text { impregnated } \\
\text { fiberglass filters }\end{array}$ & $24-72 \mathrm{~h}$ & Gas & $\begin{array}{l}\text { DMA+EA } \\
\text { TMA+PA } \\
\text { DEA }\end{array}$ & Kieloaho et al., 2013 \\
\hline \multirow[t]{3}{*}{ GC-MS } & $\begin{array}{l}\text { Percolated } \\
\text { through an acidic } \\
\text { solution }\end{array}$ & $6 \mathrm{~h}$ & Gas & $\begin{array}{l}\text { E.g. MMA, } \\
\text { DMA, EA, } \\
\text { DEA, PA, } \\
\text { BA }\end{array}$ & Akyüz, 2007 \\
\hline & $\begin{array}{l}\text { Solid-phase } \\
\text { micro-extraction } \\
\text { fiber }\end{array}$ & $30 \mathrm{~min}$ & Gas & $\begin{array}{l}\text { MMA, } \\
\text { DMA+TMA, } \\
\text { EA }\end{array}$ & $\begin{array}{l}\text { Parshintsev et al., } \\
2015\end{array}$ \\
\hline & $\begin{array}{l}\text { Pre-fired quartz } \\
\text { filters }\end{array}$ & $24 \mathrm{~h}$ & Aerosol & $\begin{array}{l}\text { MMA, } \\
\text { DMA, TMA, } \\
\text { EA, DEA, } \\
\text { PA, BA }\end{array}$ & Huang et al., 2014 \\
\hline \multirow[t]{4}{*}{$\mathrm{IC}$} & $\begin{array}{l}\text { Ion exchange } \\
\text { resin }\end{array}$ & $<1 \mathrm{~h}$ & Gas & $\begin{array}{l}\text { MMA, } \\
\text { DMA, TMA }\end{array}$ & Dawson et al., 2014 \\
\hline & $\begin{array}{l}\text { PTFE-filters with } \\
\text { a size selective } \\
\text { collection with a } \\
\text { MOUDI impactor }\end{array}$ & $\begin{array}{l}20-46 \mathrm{~h} \\
(2011), \\
23 \mathrm{~h} \\
(2012)\end{array}$ & Aerosol & $\begin{array}{l}\text { MMA, } \\
\text { DMA, } \\
\text { TMA+DEA, } \\
\text { EA*, TEA }\end{array}$ & $\begin{array}{l}\text { VandenBoer et al., } \\
2011,2012\end{array}$ \\
\hline & $\begin{array}{l}\text { Pre-fired quartz } \\
\text { filters }\end{array}$ & $24 \mathrm{~h}$ & Aerosol & $\begin{array}{l}\text { MMA, } \\
\text { DMA, TMA, } \\
\text { EA, DEA, } \\
\text { TEA, BA }\end{array}$ & Huang et al., 2014 \\
\hline & $\begin{array}{l}\text { Pre-fired quartz } \\
\text { filters }\end{array}$ & $24 \mathrm{~h}$ & Aerosol & $\begin{array}{l}\text { MMA, } \\
\text { DMA, DEA }\end{array}$ & $\begin{array}{l}\text { van Pinxteren et al., } \\
2015\end{array}$ \\
\hline IC-MS & Midget impingers & $2 \mathrm{~h}$ & $\begin{array}{l}\text { Aerosol } \\
+ \text { Gas }\end{array}$ & $\begin{array}{l}\text { E.g. MMA, } \\
\text { DMA, TMA, } \\
\text { EA, PA, BA }\end{array}$ & Verriele et al., 2012 \\
\hline LC-MS & Filter & $118-331 \mathrm{~h}$ & $\begin{array}{l}\text { Aerosol } \\
+ \text { Gas }\end{array}$ & $\begin{array}{l}\text { E.g. DMA, } \\
\text { DEA, BA }\end{array}$ & $\begin{array}{l}\text { Ruiz-Jiménez et al., } \\
2012\end{array}$ \\
\hline
\end{tabular}

$\overline{\text { HPLC }}=$ High Performance Liquid Chromatography, MOUDI = Micro Orifice Uniform Deposit Impactor 
Table 2. Online methods for measuring atmospheric amine concentrations.

\begin{tabular}{|c|c|c|c|c|}
\hline \multicolumn{5}{|c|}{ Online methods } \\
\hline $\begin{array}{l}\text { Analyse } \\
\text { instrument }\end{array}$ & $\begin{array}{l}\text { Time } \\
\text { resolution }\end{array}$ & $\begin{array}{l}\text { Amine } \\
\text { phase }\end{array}$ & Amines & Reference \\
\hline \multirow[t]{2}{*}{ CIMS } & $10 \min$ & Gas & DMA, TMA & Sellegri et al., 2005 \\
\hline & $1 \mathrm{~min}$ & Gas & C1-C6 amines & You et al., 2014 \\
\hline \multirow[t]{2}{*}{ AmPMS } & $5 \min$ & Gas & C1-C6 amines & Hanson et al., 2011 \\
\hline & $5 \mathrm{~min}$ & Gas & C1-C7 amines & Freshour et al., 2014 \\
\hline \multirow[t]{3}{*}{ CI-APi-TOF } & $30 \mathrm{~min}$ & Gas & DMA & Kulmala et al., 2013 \\
\hline & $\begin{array}{l}15 \min \\
(5 s)\end{array}$ & Gas & $\begin{array}{l}\text { DMA+EA, TMA+PA, } \\
\text { C4-amines }\end{array}$ & Sipilä et al., 2015 \\
\hline & $30 \mathrm{~min}$ & Gas & C1-C6 amines & Kürten et al., 2016 \\
\hline TOF-CIMS & $1 \mathrm{~min}$ & Gas & C1-C3 amines & Zheng et al., 2015 \\
\hline HEDS-IC & $60 \mathrm{~min}$ & Gas & $\begin{array}{l}\text { MMA, DMA, TMA, } \\
\text { EA }\end{array}$ & Chang et al., 2003 \\
\hline AIM-IC & $60 \mathrm{~min}$ & Gas+Aerosol & $\begin{array}{l}\text { MMA, DMA, } \\
\text { TMA+DEA, EA, } \\
\text { TEA }\end{array}$ & $\begin{array}{l}\text { VandenBoer et al., 2011, } \\
2012\end{array}$ \\
\hline $\begin{array}{l}\text { MARGA- } \\
\text { MS }\end{array}$ & $60 \mathrm{~min}$ & Gas+Aerosol & $\begin{array}{l}\text { MMA, DMA, TMA, } \\
\text { EA, DEA, PA, BA, } \\
\text { Guanidine }\end{array}$ & $\begin{array}{l}\text { Paper IV } \\
\text { and Paper V }\end{array}$ \\
\hline
\end{tabular}

CIMS $=$ Chemical Ionization Mass Spectrometer, AmPMS $=$ ambient pressure proton transfer mass spectrometry, CI-APi-TOF $=$ chemical ionization atmospheric pressure interface time-of-flight mass spectrometry, HEDS = High-Efficiency planar Diffusion Scrubber, AIM = Ambient Ion Monitor

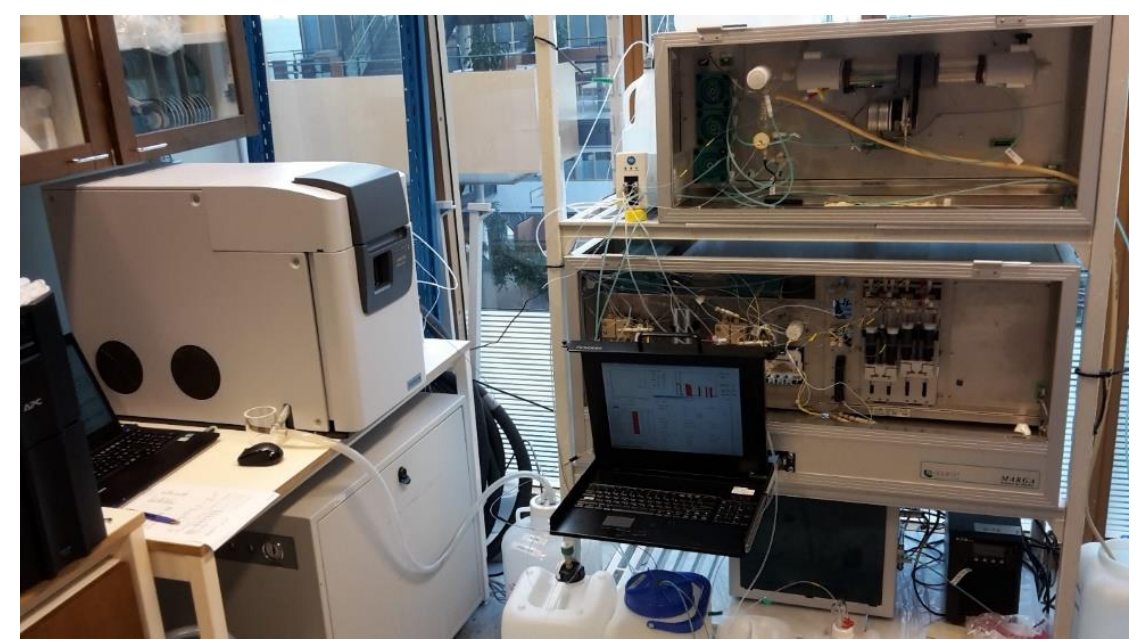


Figure 8. The MARGA-MS in laboratory environment.

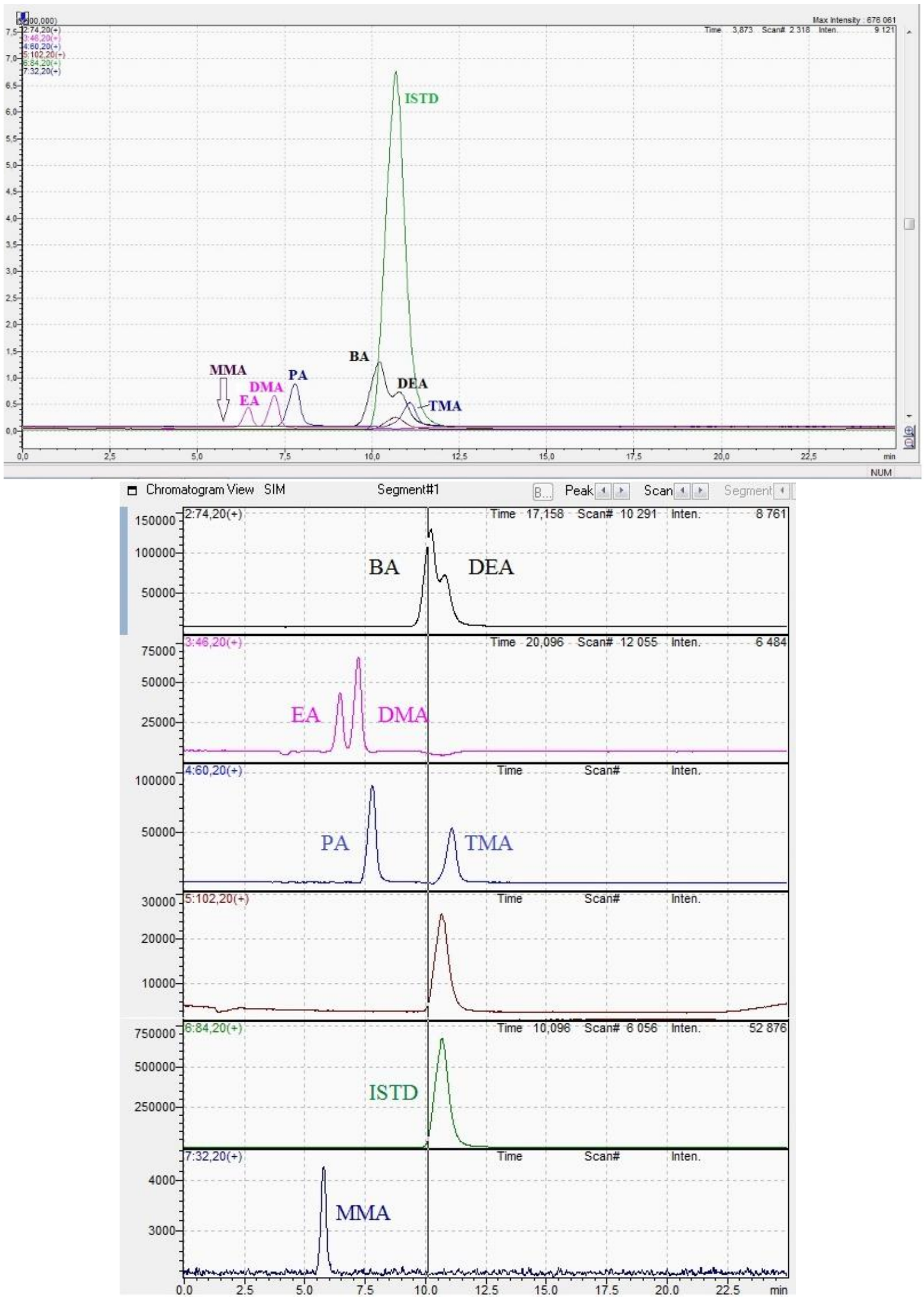

Figure 9. Example of a chromatogram of the standard solution, total chromatogram (top panel) and compounds separated by their mass-to-charge ratio (bottom panel). 
The MARGA-system has several operational modes: Measurement, Manual Measurement, Standby, Blank, Standard and Stop. The measurement mode is used, when MARGA operates normally. In the Manual Measurement mode, it is possible to feed samples to the IC-analysis directly. In the manual Measurement mode, the concentration column cannot be used, because of the counterpressure it makes. The standby mode is used, when MARGA needs some maintenance or washing, but it does not have to be in Stop mode. With the Blank and Standard modes, the air flow through the instrument is off and either the absorbance (Blank) or the standard (Standard) solution is fed into the MARGA, and the solution goes through the WRD and SJAC.

In Paper IV, different calibration methods were tested in order to quantify the detected amine concentrations. MARGA offers several opportunities for the calibration. First, in the Standard mode MARGA acquires a sample from a well-known reference concentration from an external bottle, and this sample is then introduced into MARGA through the WRD and SJAC. Unfortunately, in this way the calibration takes 6 hours per concentration level, so we did not perform the calibrations in this manner. The second way, is to perform the calibration via manual injections. In this method, MARGA operates in the Manual Measurement mode and the analytes are brought directly into the IC-separation and mass spectrometric detection. The problem with this method was that the concentration column could not be used. Because amine concentrations are low in boreal forest air, the calibration with the concentration column is a prerequisite for successful atmospheric amine measurements. Third and the adopted way in Paper IV is to feed the calibration solution first into the sampling tubes after the WRD and SJAC while MARGA was in the Measurement mode. Instead of taking a sample from the SJAC and a denuder, in this method, the sample syringes were filled from the standard solution bottle. This method leads to a considerable quicker calibration procedure ( 1 hour per concentration level) while acquiring two reference samples at the same time. By utilizing the third method, the example calibration curves shown in Fig. 10 were obtained. However, the system still needed to be monitored during the calibration process, because the air flow and heating the SJAC caused some problems almost every time.

As an internal standard (ISTD), MARGA normally uses a LiBr-solution. To have ISTD also for amines, $50.0 \mu \mathrm{L}$ deuterated diethyl- $\mathrm{d}_{10}$-amine (DEA 10 , Sigma-Aldrich: Isotec ${ }^{\mathrm{TM}}$; SigmaAldrich, St. Louis, MO, USA) was added to the 5-liter LiBr-solution bottle. DEA 10 was used because it behaves in the same way as normal DEA in the IC separation but since the hydrogen was replaced with heavier deuterium, it had a different mass than the studied amines. In the MARGA-system, the ISTD is mixed with the sample before the IC-analysis. DEA $_{10}$ was used to correct for possible losses to the instrumentation and to correct the changes in the MS response. A three-point external calibration was used for all measured alkyl amines corresponding to the concentration levels of 10, 50, and $300 \mathrm{ng} \mathrm{m}^{-3}$. 


\section{MMA}

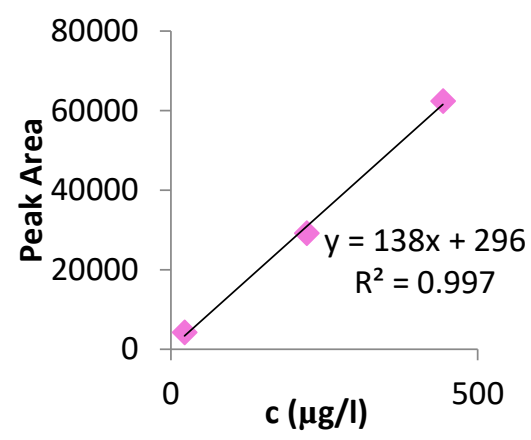

TMA
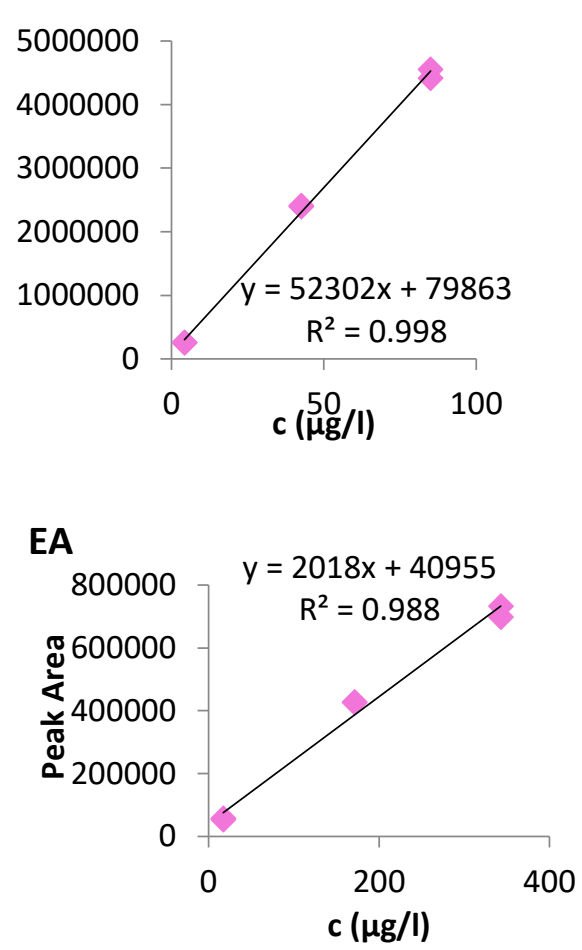

\section{DMA}

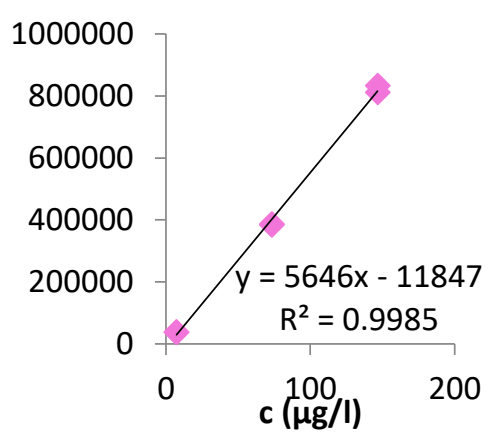

Figure 10. The calibration curves of monomethylamine (MMA), dimethylamine (DMA), trimethylamine (TMA), ethylamine (EA) and diethylamine (DEA).

With the MARGA-MS we measured ambient amine concentrations in 2015 (Paper IV), and determined forest floor amine emissions in 2018 (Paper V). During the measurement periods the instrument was calibrated once every two weeks.

The limits of detection (LODs) for the MARGA-MS were calculated from signal-to-noise ratios (3:1) for most of the compounds and they were similar both in the gas and in the aerosol phases. Due to the background concentrations detected in the blank mode measurements, the LODs specifically for DMA and TMA were calculated from the blank values ( 3 times the standard deviations of the blank values) and the LODs were different for the gas- and aerosol-phase measurements. As can be seen from Table 3, the limits of detection were low with a moderately good precision (10-15\%) and accuracy (11-37\%) for the analytical method of MARGA-MS to determine atmospheric amine concentrations. 
In addition to improved LODs compared to the LODs measured only with MARGA, MS detection after MARGA solved the problem with co-elution of amines with different molecular masses (see Fig. 9) and inorganic cations (e.g., $\mathrm{K}^{+}, \mathrm{Mg}^{2+}$ ). Also, Verriele et al. (2012) noticed that adding MS detection after a conductivity detector overcomes the coeluting problem of the IC separation, when they developed an IC-MS method for amines with offline sampling with midget impingers. In their method there was a four-step gradient elution and suppression before the conductivity detector. We wanted to keep our method as simple as possible to make it easy to use in the field, and isocratic elution without suppression was a good choice to reach that goal.

Table 3. The Limits of Detection (LOD) of different amines, ammonia and ammonium. Conversions from $\left(\mathrm{ng} \mathrm{m}^{-3}\right)$ to $\mathrm{ppt}_{\mathrm{v}}$ was performed using a conversion factor $\mathrm{ppt}_{\mathrm{v}}=\mathrm{c}\left(\mathrm{ng} \mathrm{m}^{-}\right.$ $\left.{ }^{3}\right)$ : $(0.0409 \times(\mathrm{MW}))$ by Finlayson-Pitts (2000), where MW is the molar mass of the amine, ammonia or ammonium. The precision for the IC-MS analysis was defined by calculating standard deviations of liquid $200 \mathrm{ng} \mathrm{m}^{-3}$ standard measured six times in a row. The data included both the gas and the particle side measurements. The accuracy for the IC-MS analysis was calculated by analysing several times the same known standard solution, and subtracting the averages of the results from the expected values, dividing those with the expected values and multiplying them by 100\%. Modified from Paper IV.

\begin{tabular}{|c|c|c|c|c|}
\hline Amine & $\begin{array}{l}\text { LOD } \\
\left(\mathrm{ng} \mathrm{m}^{-3}\right)\end{array}$ & $\begin{array}{l}\mathbf{L O D} \\
\left(\mathbf{p p t}_{\mathbf{v}}\right)\end{array}$ & $\begin{array}{l}\text { Precision } \\
(\%)\end{array}$ & $\begin{array}{l}\text { Accuracy } \\
(\%)\end{array}$ \\
\hline both gas and aerosol & 2.4 & 1.9 & 10 & 24 \\
\hline DMA. (March to August) & 3.1 & 1.7 & 11 & 31 \\
\hline aerosols & 1.1 & & & \\
\hline (November to December) & 0.37 & 0.20 & & \\
\hline aerosols & 0.76 & & & \\
\hline TMA, & 0.2 & 0.1 & 14 & 11 \\
\hline aerosols & 0.5 & & & \\
\hline both gas and aerosol & 0.36 & 0.19 & 11 & 16 \\
\hline both gas and aerosol & 0.24 & 0.08 & 15 & 37 \\
\hline both gas and aerosol & 0.31 & 0.13 & 11 & 21 \\
\hline both gas and aerosol & 0.26 & 0.09 & 12 & 14 \\
\hline
\end{tabular}




\section{Inorganic Nitrogen Containing Compounds in the Boreal Forest Atmosphere}

\subsection{HONO and $\mathrm{HNO}_{3}$}

Nitrous acid (HONO) and nitric acid $\left(\mathrm{HNO}_{3}\right)$ concentrations were measured in the boreal forest environment in 2010-2011 (Paper III). The maximum concentrations for both of them were detected in summer time.

\subsubsection{HONO}

For nitrous acid, the high summer concentrations support the observation that soil nitrite is a strong source of atmospheric $\mathrm{HONO}$ (Su et al., 2011). About half of the $\mathrm{NO}_{\mathrm{x}}$ emitted from the Earth's surface annually arises from fossil fuel combustion and the remainder from biomass burning and emissions from the soil (Mosier, 2001), and the amount of HONO in air depends on the $\mathrm{NO}_{\mathrm{x}}$ concentration. There are indications that HONO may be formed heterogeneously from $\mathrm{NO}_{2}$ on ground or on airborne surfaces, for instance on aerosol particles, especially soot, or cloud droplets (e.g., Gutzwiller et al., 2002). Positive correlations between $\mathrm{NO}_{\mathrm{x}}$ and $\mathrm{HONO}$ have been found. The emission and heterogeneous formation of HONO in a road traffic tunnel was studied by Kurtenbach et al. (2001), and they discovered that the mean $\mathrm{HONO}$-to- $\mathrm{NO}_{\mathrm{x}}$ ratio was $0.008 \pm 0.001$, which is indicative of domination of HONO from the traffic sources. In earlier studies, when HONO was measured in an urban background site SMEAR III (Järvi et al., 2009) in Helsinki in 20092010 (Makkonen et al., 2012), the results indicated that most of the time the concentration of HONO was larger or equal to the HONO-to- $\mathrm{NO}_{\mathrm{x}}$ ratio prediction of Kurtenbach et al. (2001). The same approach was used in Paper III. In the summer, it was noticed that the ratio deviated by up to two orders of magnitude from the expected ratio determined by Kurtenbach et al (2001), which describe the relative contributions between the traffic and other sources of HONO. This result indicates that in the summertime there might be HONO emissions from the soil that influence the observed concentrations at Hyytiälä. This is in line with observations by Su et al. (2011). The results in Paper III indicated that in other seasons, the HONO-to- $\mathrm{NH}_{\mathrm{x}}$ ratio was closer to ratio of Kurtenbach et al. (2001) suggesting a lower relative contribution from the soil.

In Paper III, diurnal variation of nitrous acid was studied in different seasons. Nitrous acid is formed in the reaction of nitrogen monoxide and hydroxyl radical (Eq. 2) and dissociated by solar radiation (Eq. 3) (Finlayson-Pitts and Pitts 2000).

$$
\begin{aligned}
& \mathrm{NO}+\mathrm{OH} \bullet+\mathrm{M} \rightarrow \mathrm{HONO}+\mathrm{M} \\
& \mathrm{HONO}+\mathrm{h} v \rightarrow \mathrm{OH} \bullet+\mathrm{NO}
\end{aligned}
$$


Hence, concentrations of HONO are typically higher at night and lower during the day. In Hyytiälä, the diurnal variation of the HONO concentrations was clear in the summer, but imperceptible during the winter and only very modest during the spring (Fig. 11). In the autumn the HONO concentrations still had some diurnal variation. As discussed above, the observed HONO-to-NOx ratios suggest that a significant fraction of the measured HONO is emitted from the soil. However, this data does not distinguish whether or not there is a diurnal cycle in the emission rate or whether the cycle is driven by photochemistry.

\subsubsection{HNO3}

Since formation of nitric acid $\left(\mathrm{HNO}_{3}\right)$ requires nitrogen dioxide and solar radiation, the highest seasonal average of $\mathrm{HNO}_{3}$ concentration $(0.10 \mathrm{ppb})$ was measured in summer. The average concentration of nitric acid at Hyytiälä was $0.07 \mathrm{ppb}$. It is at the same level as what has been measured in south-eastern Scotland (0.05 ppb, Cape 2009), both results were determined with MARGA. The average concentration level was lower than measured in the urban environment in Helsinki ( $0.13 \mathrm{ppb}$ in winter and $0.22 \mathrm{ppb}$ in spring, Makkonen et al. 2012).

Diurnal variation of nitric acid was explored in Paper III. Nitric acid is formed between the reaction of nitrogen dioxide and hydroxyl radical $\mathrm{OH} \bullet$ (Eq. 4), which is formed in photochemical reactions in sunlight (Finlayson-Pitts and Pitts 2000).

$\mathrm{NO}_{2}+\mathrm{OH} \bullet+\mathrm{M} \rightarrow \mathrm{HNO}_{3}+\mathrm{M}$

The results in Paper III are in agreement with the reaction path, and also with the earlier study conducted at Hyytiälä (Janson et al., 2001). A clear diurnal cycle was observed in the summer, with the maximum in the afternoon at 14:00-18:00 (Fig. 11). However, the peak concentration was observed several hours later than expected, since $\mathrm{OH}$-radicals producing $\mathrm{HNO}_{3}$ from $\mathrm{NO}_{2}$ typically have their highest concentrations at noon (Petäjä et al., 2009). 

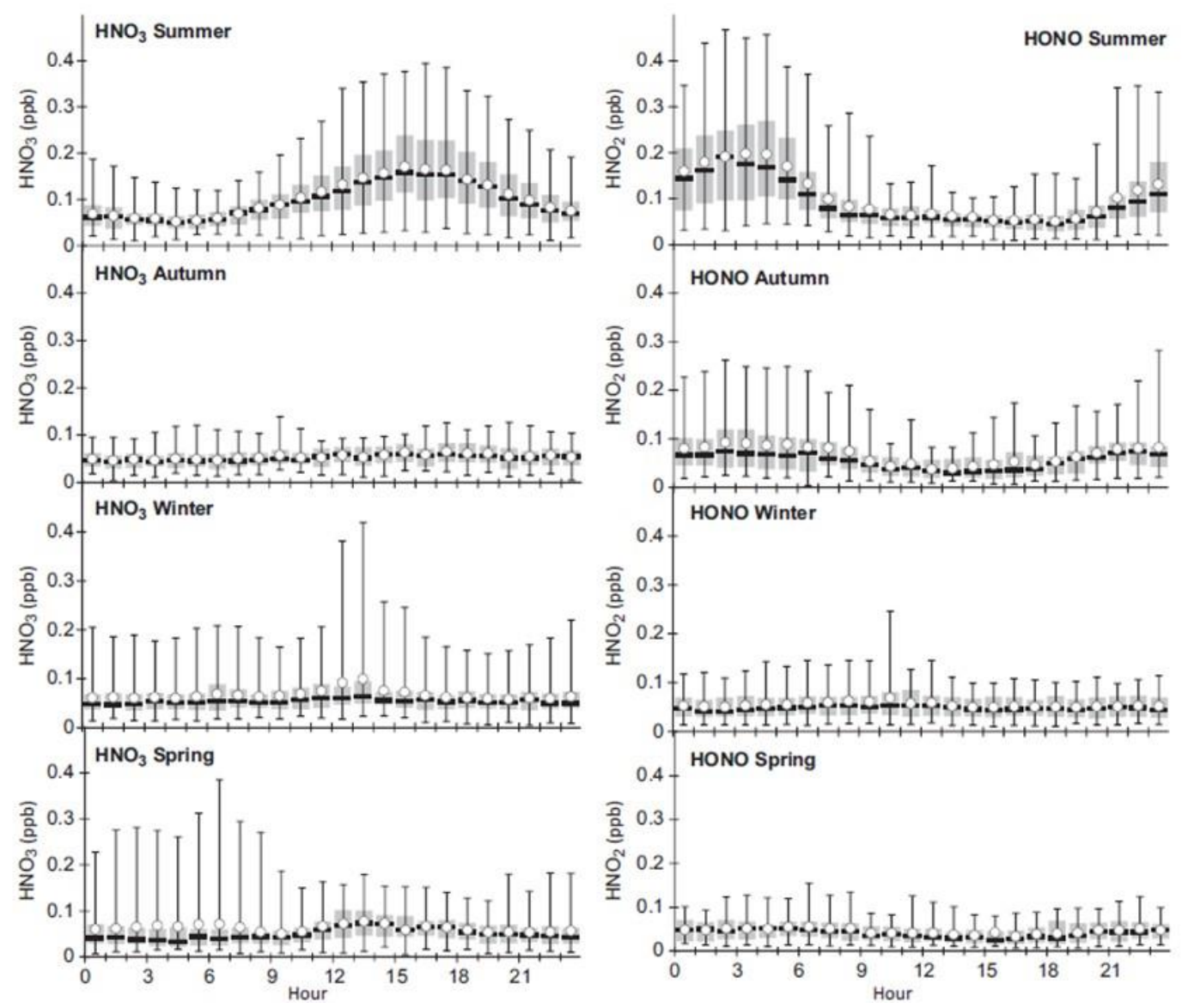

Figure 11. The diurnal variation of nitric and nitrous acids during the four seasons. The box represents the 25th to 75th percentile range, the bars illustrate the 5th and 95th percentiles, the horizontal line depicts the median and the circle shows the averages of the hourlyaveraged data for each hour. Adapted from Paper III.

\subsection{Ammonia and Ammonium}

In Papers III-V the nitrogen containing compounds in the boreal forest atmosphere were studied with MARGA 2s (Paper III) and MARGA-MS (Paper IV and V). In Paper III ammonia and ammonium were studied separately in the boreal forest air, and in Paper IV the sum of them: $\mathrm{NH}_{\mathrm{x}}$. Here the results of these papers are compared the sum of the gas phase and particulate matter nitrogen compounds. The results from Paper III showed that the $\mathrm{NH}_{\mathrm{x}}$ concentrations were the highest (mean $\sim 0.88 \mu \mathrm{g} \mathrm{m}^{-3}$ ) in summer followed by winter (mean $\sim 0.42 \mu \mathrm{g} \mathrm{m}^{-3}$ ) and spring and autumn (mean $\sim 0.36 \mu \mathrm{g} \mathrm{m}^{-3}$ ). A similar seasonal variation for ammonia as was shown in Paper III, have also been noticed in Canada (Zbieranowski and Aherne, 2012). The main reason for seasonal variation of ammonia is that agricultural sources are lower during the cold period. Agricultural outdoor activities start normally in May in Finland, leading to increased ammonia concentrations (RuohoAirola et al., 2010). 
There are some differences between the sum of ammonia and ammonium presented in Paper III and in Paper IV. In Paper IV, the highest concentrations of $\mathrm{NH}_{\mathrm{x}}$ were measured in March (mean $0.48 \mu \mathrm{g} \mathrm{m}^{-3}$ ), and in July the concentrations were much lower (mean 0.18 $\mu \mathrm{g} \mathrm{m}^{-3}$ ) compared to the results in Paper III. Overall, the $\mathrm{NH}_{\mathrm{x}}$ concentrations reported in Paper III were higher than the corresponding concentrations in Paper IV. One of the reasons for this could be that the measurement periods were shorter in Paper IV. Therefore, the mean values were calculated from shorter time periods, that lasted only a couple of days. The meteorological conditions during the different campaigns differed as well. The temperature in the year 2010 (Paper III) summer period was mostly higher than during the July 2015 measurements (Paper V), but when comparing August measurement periods to each other, Paper IV temperatures were significantly higher.

Diurnal variations of ammonia and ammonium from summer 2010 to spring 2011 were presented in Paper III. In summer, the diurnal cycle of the ammonia concentration was significant, with a maximum in the afternoon (Fig. 12). However, at the same time, there was no diurnal variation observed for particulate ammonium. Hence, the summertime diurnal variation of ammonia cannot be explained by the dissociation of $\mathrm{NH}_{4} \mathrm{NO}_{3}$ to gas phase $\mathrm{NH}_{3}$ and $\mathrm{HNO}_{3}$. In winter, no clear diurnal variation was observed and the ammonia concentrations remained very low, mainly below $0.1 \mathrm{ppb}$, for most of the time. In March, there was no diurnal cycle, but the dynamic variation in the concentrations as a whole was stronger, with a maximum concentration of about $1 \mathrm{ppb}$. From the end of April the diurnal cycle of ammonia was apparent once again when the agricultural activities started after winter.
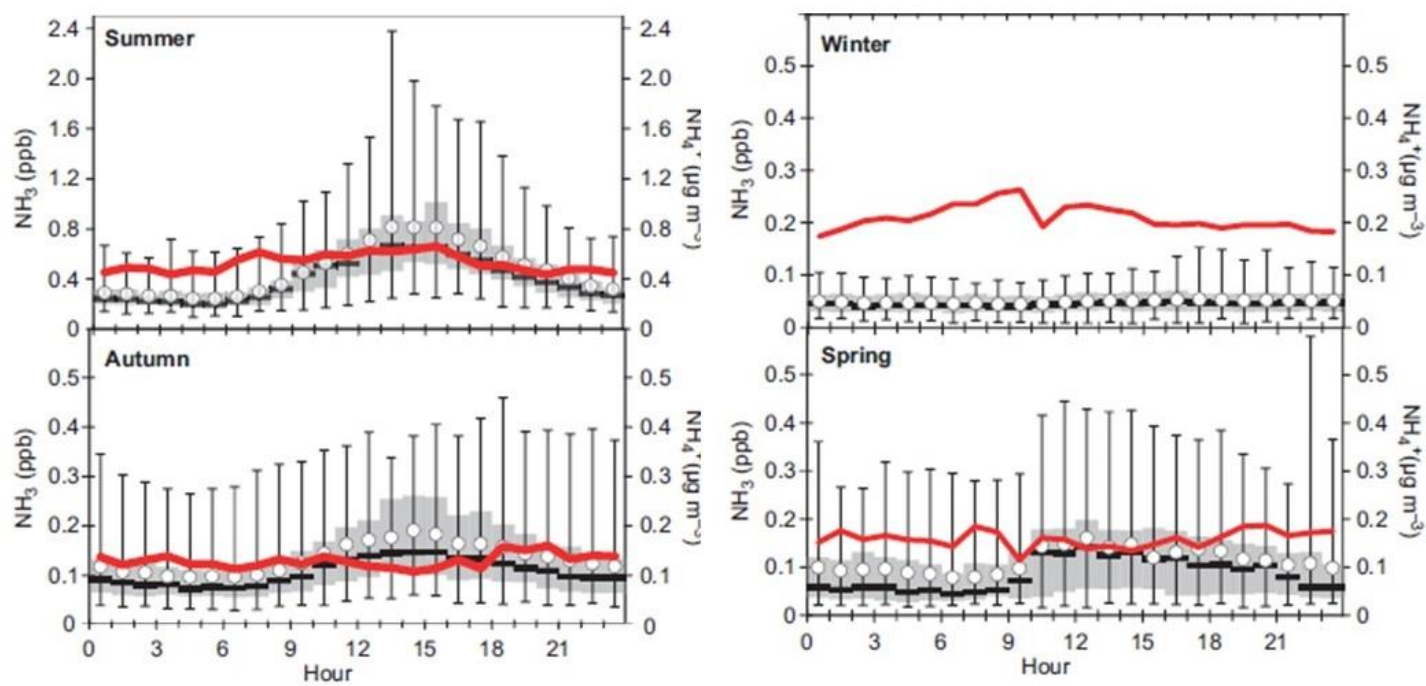

Figure 12. Diurnal cycle of ammonia during the four seasons. The box represents the 25th to $75^{\text {th }}$ percentile range, the bars the $90 \%$ range ( 5 th and 95 th percentiles), the horizontal line indicate the median and the circle present the averages of the hourly-averaged data for each hour. The red lines depict the medium ammonium concentrations $\left(\mu \mathrm{g} \mathrm{m}^{-3}\right)$ in PM10 fraction. Adapted from Paper III. 


\section{Amines in the Boreal Forest Ambient Air and Their Possible Sources}

\subsection{Ambient Concentrations}

Amines were measured in Hyytiälä in 2015 and 2018. In 2015, we measured the concentrations of monomethylamine (MMA), dimethylamine (DMA), trimethylamine (TMA), ethylamine (EA), diethylamine (DEA), propylamine (PA) and butylamine (BA) (Fig. 13) from ambient air (Paper IV). The measurements started in March and ended in December 2015, providing about 8 weeks of quantified data. The gaps in the data were caused by instrument failures. In the following summary of the results, the gas phase amines are marked as amine(g), aerosol phase as amine(a) and their sum as amine(tot) for each of the amine groups. For example, for monomethyl amine as follows: MMA(g), MMA(a), MMA(tot), to make it easier to understand the discussion.<smiles>CN</smiles>

Monomethylamine

(MMA)<smiles>CCN</smiles>

Ethylamine (EA)<smiles>CNC</smiles>

Dimethylamine

(DMA)<smiles>CCNCC</smiles>

Diethylamine

(DEA)

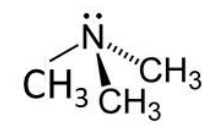

Trimethylamine

(TMA)<smiles>CCCN</smiles>

Propylamine

(PA)<smiles>CCCCN</smiles>

Butylamine

(BA)<smiles>N=C(N)N</smiles>

Guanidine

Figure 13. The structures of different amines and guanidine.

\subsubsection{Monomethylamine (MMA)}

The highest concentrations of MMA(tot) were detected in spring (max. $50 \mathrm{ng} \mathrm{m}^{-3}$ ), and the concentrations correlated with the sum of $\mathrm{NH}_{3}$ and $\mathrm{NH}_{4}{ }^{+}\left(\mathrm{R}^{2}=0.52\right)$ (Paper IV). There were also two occasions in spring (Fig. 14), when the concentrations of MMA(tot) and $\mathrm{NH}_{3}+\mathrm{NH}_{4}{ }^{+}$increased considerably at the same time. In March this increase coincided with rain, and in April the high concentrations were associated with night time with lower wind speed and higher temperature. Based on these observations we speculate that this increase in MMA(tot) could be connected to the melting snow and to the thawing of the soil. This observation was one of the inspirations to start emission measurements that were reported in Paper V. To explain the higher concentrations, Bigg et al. (2001) suggested that water from the melting snow penetrates the soil and leaf litter under the snow, hence displacing the nitrogen containing gases produced in decomposition of the organic material. These gases are then released into the air, where they can participate in the nucleation process 
(Almeida et al., 2013). The hypothesis is that this bubbling of gases is more efficient in humid conditions, but the evaporation and release to the air are more efficient on warm, sunny days. Furthermore, the lack of oxygen in the wet soil can enhance the formation of the nitrogen containing compounds inside the soil while the snow cover would slow down the evaporation of gases and hinder their release into the atmosphere. Later on, when the snow melts, the vapours would be released in an intensive emission peak.
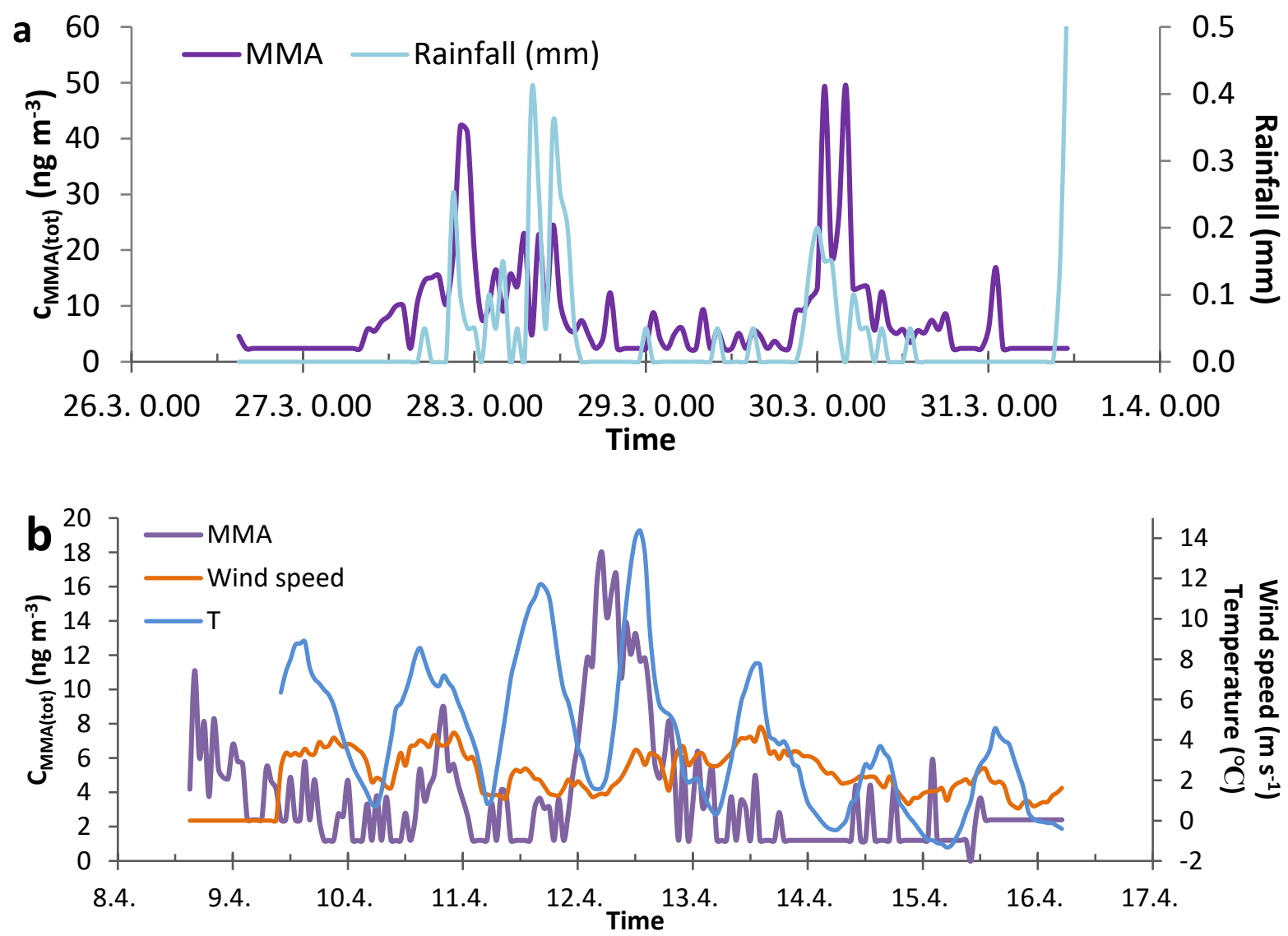

Figure 14. MMA(tot) concentrations and rainfall measured in Hyytiälä during spring 2015 in March (a) and MMA(tot) concentrations, wind speed and ambient temperature in April (b).

To contrast the results of Paper IV, we compared the concentrations with earlier MMA $(\mathrm{g})$ measurements. The summary is presented in Table 4. Generally, our observations are in line with the results from the literature. For example, You et al. (2014) measured MMA(g) in a rural forest environment in summer time in Alabama, USA, with CIMS. Their maximum concentration for the MMA(g) was $\sim 2$ ppt $_{v}$, whereas Freshour et al. (2014) determined a variable concentration between 4-5 $\mathrm{ppt}_{\mathrm{v}}$ in rural, semi-rural and urban areas in the USA with AmPMS. Because many MMA sources are expected in urban areas (e.g. industry and vehicular traffic) as summarized in Ge et al. (2011), it was surprising that the MMA(g) concentrations in the urban areas are approximately at the same level as our results from the boreal forest. On the other hand, Ge et al. (2011) also lists natural sources of MMA, like vegetation and soil (Ge et al., 2011). Our finding is consistent with Akyüz (2007), who 
measured MMA $(\mathrm{g})$ in urban area in Turkey during summer $\left(0.005 \mathrm{ppt}_{\mathrm{v}}\right)$ and winter time $\left(0.085 \mathrm{ppt}_{\mathrm{v}}\right)$.

\subsubsection{Dimethylamine (DMA)}

DMA(tot) had the highest ambient concentrations in the boreal forest atmosphere in July (Paper IV). The partitioning between the gas and aerosol phases favored the latter i.e. typically there was higher concentration of DMA in the particle phase (max. $55.5 \mathrm{ng} \mathrm{m}^{-3}$ ) (Table 4) than in the gas phase ( $\max 4.1 \mathrm{ppt}_{\mathrm{v}}$ ). It is expected that amines can effectively partition in the aqueous aerosols (Ge et al., 2010), and therefore it is not surprising to find them mostly in the aerosol phase taking into account a fairly high average relative humidity (>68\%). The aerosol in the boreal environment is typically at least slightly water soluble (Hämeri et al., 2001; Petäjä et al., 2005; Ehn et al. 2007). Considering that the accumulation mode aerosol particles have underwent several cloud processing cycles during their residence time in the atmosphere, it is plausible that there is liquid water in the aerosol phase, when the ambient RH is higher than $50 \%$ (Swietlicki et al., 2008). The concentrations of DMA(tot) decreased in August, but we still observed a diurnal cycle with a maximum at noon. The maximum at noon could indicate a light-dependent source for DMA, because also the concentration of isoprene, which has a light-dependent source and is thus not emitted in the night, peaks during daytime while BVOCs (e.g. mono- and sesquiterpenes) with temperature-dependent emissions peak during the night (Hakola et al. 2012, Hellén et al. 2018). Temperature dependent emissions are also highest during the daytime, but high night-time concentrations are explained by the very low mixing layer heights during summer nights at the site. The daytime ambient maximum could also be caused by re-emission of DMA from the surfaces. Kieloaho et al. (2013) measured high gas-phase concentrations of the sum of DMA and EA in July, reaching a maximum of $\sim 75 \mathrm{ppt}_{\mathrm{v}}$ (approximately $138 \mathrm{ng}$ $\mathrm{m}^{-3}$ ) at Hyytiälä. Their data showed that the concentration levels decreased in August, which

agrees with our results. Schobesberger et al. (2015) and Sipilä et al. (2015) carried out measurements at Hyytiälä in spring 2011 and 2013, respectively, and according to their results, DMA(g) concentrations were mostly below 1-1.5 ppt . In Paper IV, we also observed low concentrations in the spring time, and our maximum gas phase concentration of DMA was 4.1 ppt $_{\mathrm{v}}$ (Table 4), in agreement with Schobesberger et al. (2015) and Sipilä et al. (2015).

The concentration of $\operatorname{DMA}(\mathrm{g})$ had a positive correlation both with air and with soil temperature (Fig. 15). However, the correlation with the soil temperature seemed to depend on the measurement period and the positive correlation was most evident in the summer (Fig. 16). Relative humidity correlated negatively with DMA(g) concentrations (Fig. 15), which is in accordance with the hypothesis that amines partition effectively the aqueous phase aerosol particles (Ge et al., 2010) predominantly in high RH conditions. The most consistent relationships of $\mathrm{DMA}(\mathrm{g})$ are with air and soil temperature; the slopes of the linear regressions are positive for all of the data and for summer alone (Fig. 16). In Paper V, we 
noticed, that also DMA emissions from the forest floor have dependency on air and soil temperature, confirming our observations from Paper IV.
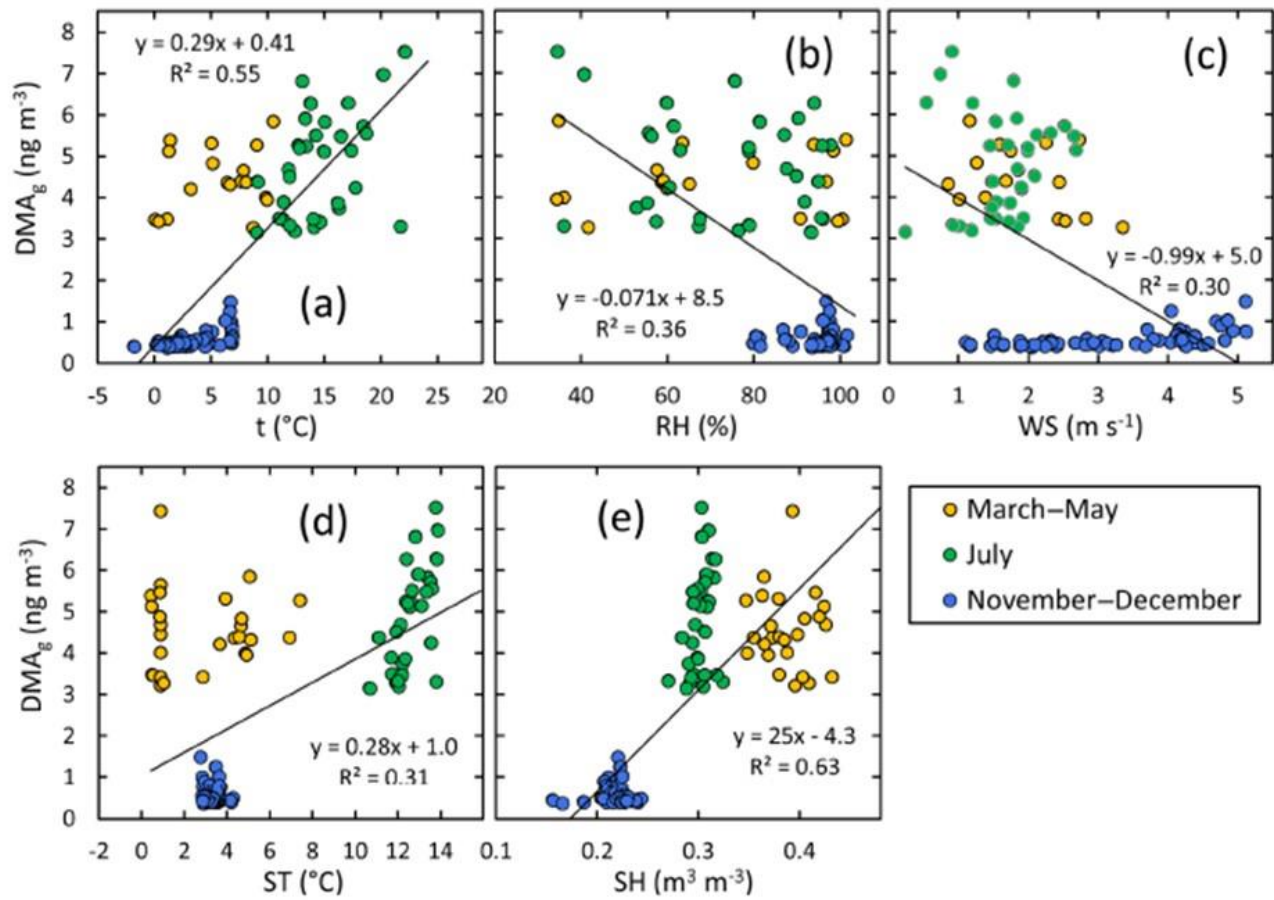

o March-May

- July

- November-December

Figure 15. DMA concentration at Hyytiällä in the gas phase as a function of selected ambient conditions: (a) air temperature, (b) relative humidity, (c) wind speed, (d) soil temperature, and (e) soil humidity classified according to the season (March-May represents spring, July is summer, and November and December are classified as early winter). The linear regressions shown in the plots were calculated using the data points of all the seasons. Adapted from Paper IV.

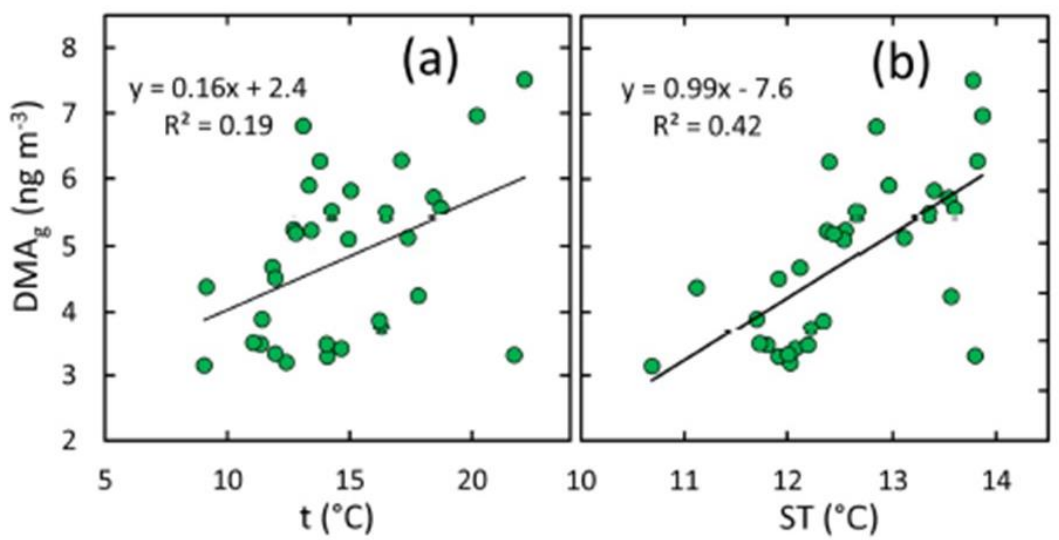

Figure 16. DMA concentration in the gas phase as a function of (a) air temperature and (b) soil temperature in summer. Adapted from Paper IV. 


\subsubsection{Trimethylamine (TMA)}

Ambient TMA(tot) concentrations peaked in March, at the time as MMA(tot) and $\mathrm{NH}_{3}+\mathrm{NH}_{4}{ }^{+}$. A secondary maximum was in July, being indicative of a biogenic source. Ambient TMA $(\mathrm{g})$ concentrations tended to decrease, when air and soil temperatures increased. Therefore, the behaviour was opposite to DMA(g). As already mentioned, TMA concentrations were high in spring and we speculated in Paper IV, that they could originate partly from the melting snow and ground. DMA might have biogenic sources in summer, which could explain the different correlation behaviour. Compared to other studies conducted in Hyytiälä (Sellegri et al., 2005; Kieloaho et al. 2013, Table 2), the TMA(g) concentrations that we measured were much smaller. Sellegri et al. (2005) measured TMA(g) with CIMS, so their results probably contained all amines with the same mass as TMA i.e. C3 amines, and this is a possible explanation for the difference. Also guanidine has the same mass than TMA and PA. Kieloaho et al. (2013) measured the sum of gaseous TMA and propylamine, which could also explain the differences. It would also be interesting to compare these measurement methods in a campaign, so the differences caused by ambient conditions would be minimized.

\subsubsection{Ethylamine (EA)}

Ethylamine concentration was the only amine, which had a similar diurnal cycle as the monoterpene concentrations measured at the same time. Both illustrated a maximum concentration in the night (Paper IV). This type of diurnal variation is typical for many reactive compounds that have local sources in the boreal forest (Hakola et al., 2012). The low daytime concentrations were due to strong atmospheric mixing combined with effective oxidation by $\mathrm{OH}$ radicals. Kürten et al. (2016) measured $\mathrm{C} 2$ amines (i.e., DMA and EA) with a CI-APi-TOF in Germany near three dairy farms and a forest from May to June 2014 They did not observe a clear diurnal cycle for the $\mathrm{C} 2$ amines. In our measurements, EA and DMA had opposite diurnal variations and it could be that these opposite cycles cancel each other out and thus the total C2 amine concentration determined by Kürten et al. (2016) show not such variation. 
Table 4. Comparison of ambient air concentrations of MMA, DMA, TMA and EA in different sites and seasons, gas and aerosol phase. Adapted from Paper IV.

\begin{tabular}{|c|c|c|c|c|c|c|c|}
\hline Amine & $\begin{array}{l}\text { Gas } \\
\left(\mathbf{p p t}_{\mathbf{v}}\right)\end{array}$ & $\begin{array}{l}\text { Aerosol } \\
\left(\text { ng m }^{-3}\right)\end{array}$ & $\begin{array}{l}\text { Site } \\
\text { description }\end{array}$ & Location & Season & Year & Reference \\
\hline \multirow[t]{7}{*}{ MMA } & $<\mathrm{DL}-8.8$ & $<\mathrm{DL}-61.2$ & Rural forest & Finland & Spring-early winter & 2015 & Paper IV \\
\hline & $\max . \sim 2$ & & Rural forest & AL, USA & Summer & 2013 & You et al. (2014) \\
\hline & 5 & & Semi-rural & DE, USA & Summer & 2012 & Freshour et al. (2014) \\
\hline & 4 & & Rural & OK, USA & Spring & 2013 & Freshour et al. (2014) \\
\hline & 4 & & Urban & MN,USA & Autumn & 2012 & Freshour et al. (2014) \\
\hline & 0.005 & & Urban & Turkey & Summer & 2004-2005 & Akyüz (2007) \\
\hline & 0.085 & & Urban & Turkey & Winter & $2005-2006$ & Akyüz (2007) \\
\hline \multirow[t]{12}{*}{ DMA } & $<\mathrm{DL}-4.1$ & $<\mathrm{DL}-55.5$ & Rural forest & Finland & Spring-early winter & 2015 & Paper IV \\
\hline & $\max \sim 7^{\mathrm{a}}$ & & Rural forest & AL, USA & Summer & 2013 & You et al. (2014) \\
\hline & $28^{\mathrm{a}}$ & & Semi-rural & DE, USA & Summer & 2012 & Freshour et al. (2014) \\
\hline & $20^{\mathrm{a}}$ & & Rural & OK, USA & Spring & 2013 & Freshour et al. (2014) \\
\hline & $42^{\mathrm{a}}$ & & Urban & MN,USA & Autumn & 2012 & Freshour et al. (2014) \\
\hline & 1.18 & & Urban & Turkey & Summer & 2004-2005 & Akyüz (2007) \\
\hline & 1.61 & & Urban & Turkey & Winter & $2005-2006$ & Akyüz (2007) \\
\hline & $<2.7$ & $<2.7$ & Urban & Canada & Summer & 2009 & VandenBoer et al. (2011) \\
\hline & $6.5 \pm 2.1$ & $0.1 \pm 0.2$ & Rural & Canada & Autumn & 2010 & VandenBoer et al. (2012) \\
\hline & $42 \pm 30^{\mathrm{a}}$ & & Rural forest & Finland & May-October & 2011 & Kieloaho et al. (2013) \\
\hline & $\max 10$ & & Urban & GA, USA & Summer & 2009 & Hanson et al. (2011) \\
\hline & & $9.3-20.5$ & Semi-arid & AZ, USA & Whole year & $2012-2013$ & Youn et al. (2015) \\
\hline \multirow[t]{12}{*}{ TMA } & $<\mathrm{DL}-6.1$ & & Rural forest & Finland & Spring-early winter & 2015 & Paper IV \\
\hline & $34-80$ & & Rural forest & Finland & Spring & 2002 & Sellegri et al. (2005) \\
\hline & $\max . \sim 20^{\mathrm{b}}$ & & Rural forest & USA & Summer & 2013 & You et al. (2014) \\
\hline & $6^{\mathrm{b}}$ & & Semi-rural & DE, USA & Summer & 2012 & Freshour et al. (2014) \\
\hline & $35^{\mathrm{b}}$ & & Rural & OK, USA & Spring & 2013 & Freshour et al. (2014) \\
\hline & $19^{b}$ & & Urban & MN,USA & Autumn & 2012 & Freshour et al. (2014) \\
\hline & $15^{b}$ & & Rural forest & AL, USA & Summer & 2013 & You et al. (2014) \\
\hline & $<2.7^{\mathrm{c}}$ & $<2.7^{\mathrm{c}}$ & Urban & Canada & Summer & 2009 & VandenBoer et al. (2011) \\
\hline & $\sim 1^{\mathrm{c}}$ & $1 \pm 0.6^{\mathrm{c}}$ & Rural & Canada & Autumn & 2010 & VandenBoer et al. (2012) \\
\hline & $21 \pm 23$ & & Rural forest & Finland & May-October & 2011 & Kieloaho et al. (2013) \\
\hline & $\leq 6.8 \times 10^{3}$ & & Agricultural & CA, USA & Autumn & 2013 & Dawson et al. (2014) \\
\hline & & $\max 9 \pm 7$ & Wildfire ${ }^{\#}$ & Canada & Summer & 2015 & Place et al. (2017) \\
\hline \multirow[t]{2}{*}{ EA } & $<\mathrm{DL}-8.2$ & & Rural forest & Finland & Spring-early winter & 2015 & Paper IV \\
\hline & 0.19 & & Urban & Turkey & Winter & 2005-2006 & Akyüz (2007) \\
\hline
\end{tabular}

a: Mass 46 i.e. DMA+EA, b: Mass 60 i.e. TMA+PA, c: TMA+DEA, *: Units in $\mathrm{ng} \mathrm{m}^{-3}$, \#: Samples are collected in British Columbia during wildfires 


\subsection{Amine Emissions from the Boreal Forest Floor}

\subsubsection{Seasonal Variability of Emissions}

In Paper V, we measured amine (MMA, DMA, TMA, EA, DEA and PA) and guanidine emissions from the boreal forest soil with a dynamic flow through chamber in Hyytiälä year 2018. The chamber measurements lasted for about one week at a time and the measurement months were April, May, July and September. In Paper IV, we measured ambient concentrations of amines in Hyytiälä year 2015. The monthly means of ambient concentrations and forest floor emission rates are shown in Fig. 17.
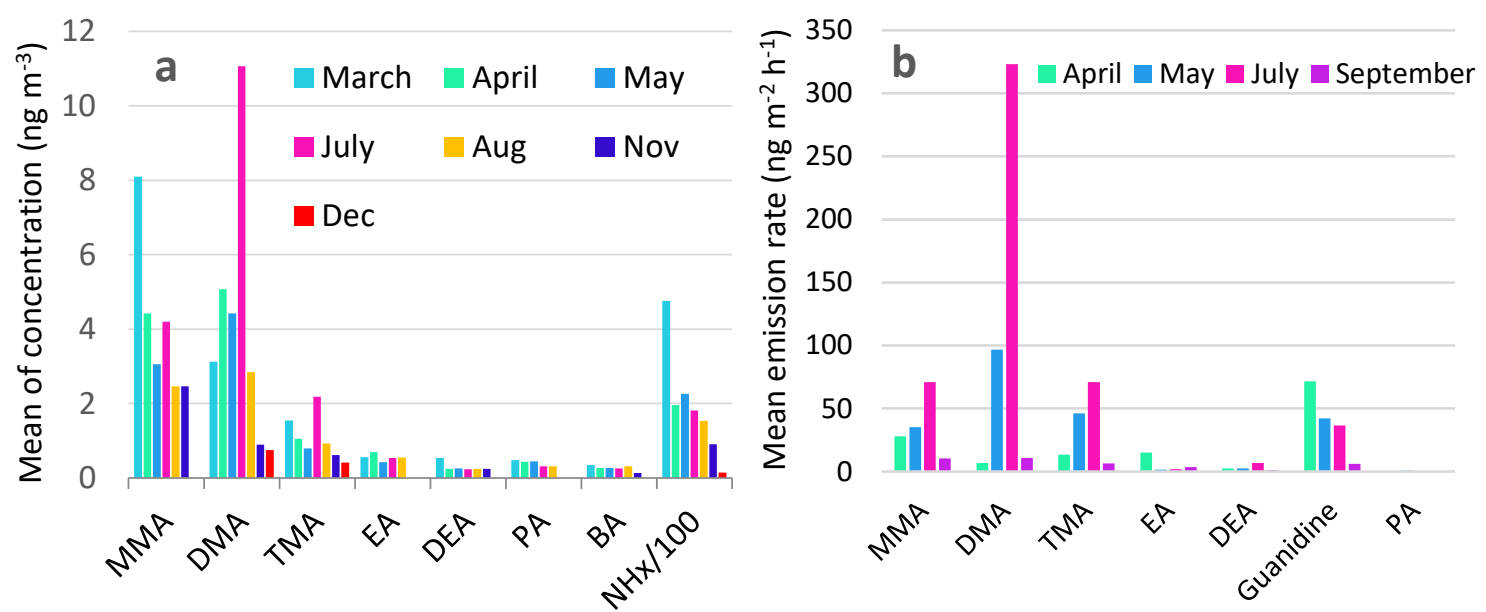

Figure 17. The mean of total amine and ammonia+ammonium concentrations (ng m$\left.{ }^{-3}\right)(a)$, and the emission rates of amine and guanidine forest floor emissions $\left(\mathrm{ng} \mathrm{m}^{-2} \mathrm{~h}^{-1}\right)$ (b). The $\mathrm{NH}_{3}+\mathrm{NH}_{4}{ }^{+}$concentrations are divided by a factor of 100 to fit the same scale. The means represent the measurement periods in each month, so the concentrations and emissions rates are not averaging whole months. Fig. 17 a is adapted from supplementary material of Paper IV whereas Fig. $17 \mathrm{~b}$ is adapted from Paper V.

When comparing emission rates from 2018 and ambient air concentrations from 2015 (Fig. 17), some similarities can be found. For example, for DMA and TMA, the highest ambient concentrations and the highest emission rates were measured in July. However, MMA had the highest concentrations in the spring (March and April), but the highest emission rates in July. We speculated in Paper IV, that the high MMA concentrations could be caused by the melting snow and thawing of the soil. During the emission measurement period, the snow melted from the chamber in April 2018. This coincided with the higher emissions in the time series during that time. However, the emission rates were lower especially for MMA than we were expecting based on the ambient measurements in Paper IV, where the highest MMA concentrations were measured in March and April. One reason could be the differences between the years and measured periods. 
We included guanidine measurements to our method in 2018, because it was shown to be a very efficient compound for new particle formation by Myllys et al. (2018). They concluded that guanidine could be an even more efficient stabilizer for sulphuric acid clusters than amines. Guanidine is a catabolite of arginine and has been found in urine (Marescau et al. 1992, Van Pilsum et al., 1956). Arginine concentrations have been detected in a boreal forest in Alaska, USA (Werdin-Pfisterer et al., 2009). In Paper V we observed guanidine emissions from the boreal forest floor, with maximum emission rates in the spring and decreasing rates towards the autumn. Noteworthy is that ammonia concentrations in Paper IV had a similar pattern. This could indicate a common source for both compounds. Unfortunately, the conductivity detector of MARGA was not working properly in 2018 and we were not able to determine ammonia emissions for the whole period. Therefore, we could not verify the hypothesis of the common source for ammonia and guanidine.

\subsubsection{Diurnal Variability of Emissions}

We observed a diurnal cycle in different amine (MMA, DMA and TMA) and guanidine emissions in May and especially in July, with maxima in the afternoon (Fig. 18). Also DEA, which did not show a clear diurnal cycle in other measurement periods, had a coinciding peak in July. In Paper IV, we detected a diurnal cycle with a maximum in the afternoon for the DMA ambient concentrations in August, although the absolutely highest concentrations were measured in earlier months. Compared to the emissions of the other amines and guanidine, trimethylamine emissions peaked earlier in the afternoon (Fig. 18), possibly because it has a lower boiling point than the other amines, and therefore it evaporates more easily. 

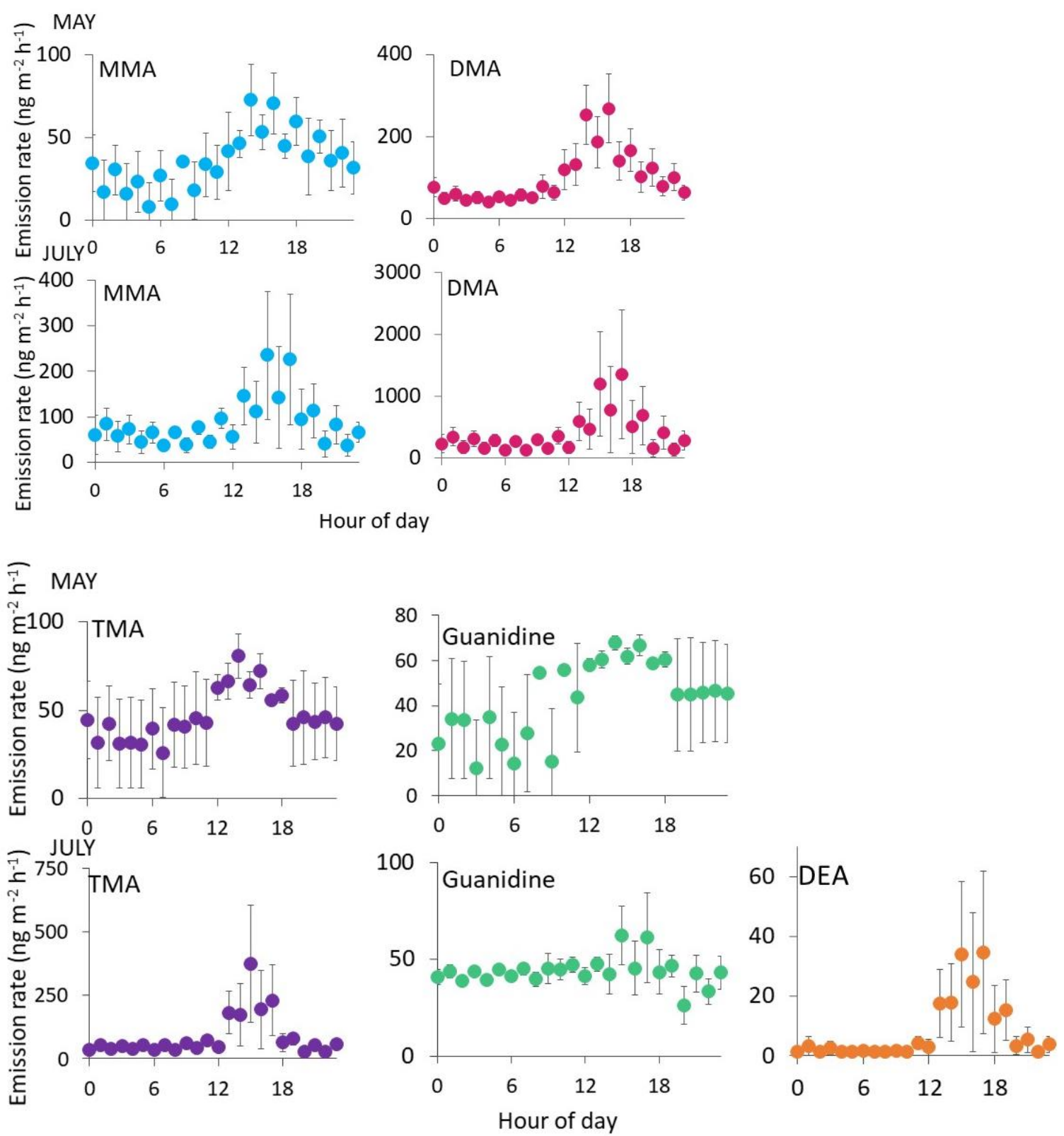

Figure 18. Typical diurnal variation of emissions of different amines and guanidine in May and July. 


\subsubsection{Effect of Environmental Parameters on the Emission Rates}

As in Paper IV with ambient concentrations, we noticed in Paper $\mathbf{V}$ that the amine emissions from the forest floor were temperature dependent. Both the DMA emissions (Fig. $\left.19, R^{2}=0.46\right)$ and the DMA (g) ambient concentrations (Fig. $13, \mathrm{R}^{2}=0.55$, Paper IV) had a reasonable correlation coefficient with the air temperature. Also the TMA emissions had a weak dependency on the air temperature $\left(\mathrm{R}^{2}=0.47\right)$, but MMA had only a moderate dependency $\left(\mathrm{R}^{2}=0.26\right)$ when the air temperature was higher than $15^{\circ} \mathrm{C}$.
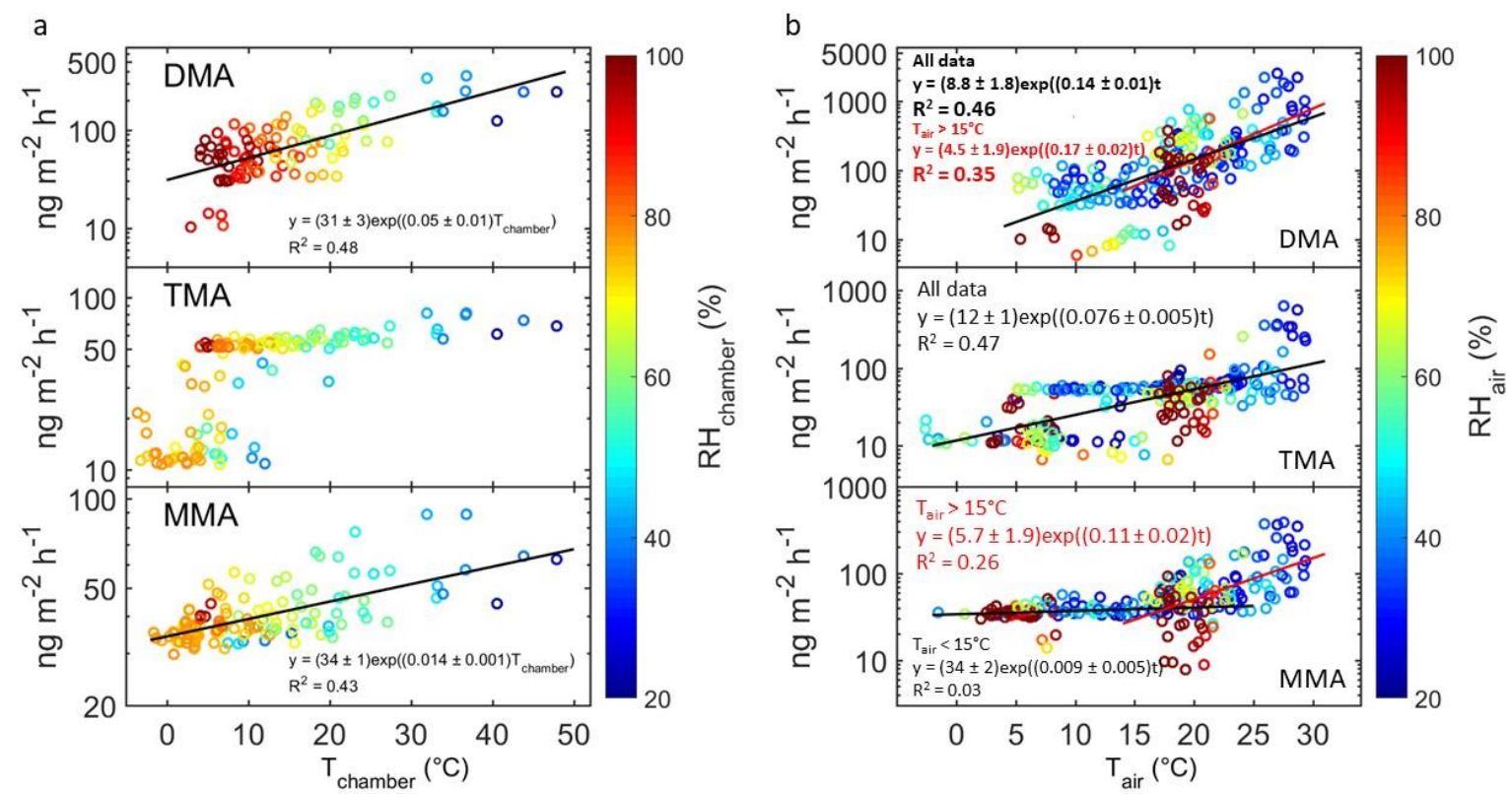

Figure 19. Emissions of three amines as a function of the chamber temperature and relative humidity (a) and outdoor air temperature and relative humidity (b). Note that in (a) there are data only until $28^{\text {th }}$ of May due to the malfunctioning of the RH sensor in the chamber and the highest emissions were observed in July. Note also the different scales in both $\mathrm{x}$ and $\mathrm{y}$ axes in (a) and (b).

In Paper IV, we noticed a positive correlation with the soil temperature and the ambient concentration of DMA(g) (Fig. 20). Also the correlation between the soil humidity and DMA(g) was positive. In Paper V, we observed a positive correlation with the soil temperature and the DMA emissions, but a negative correlation with the soil humidity. As amines are water soluble it is plausible that in the high soil humidity conditions amines would stay in the soil water. 


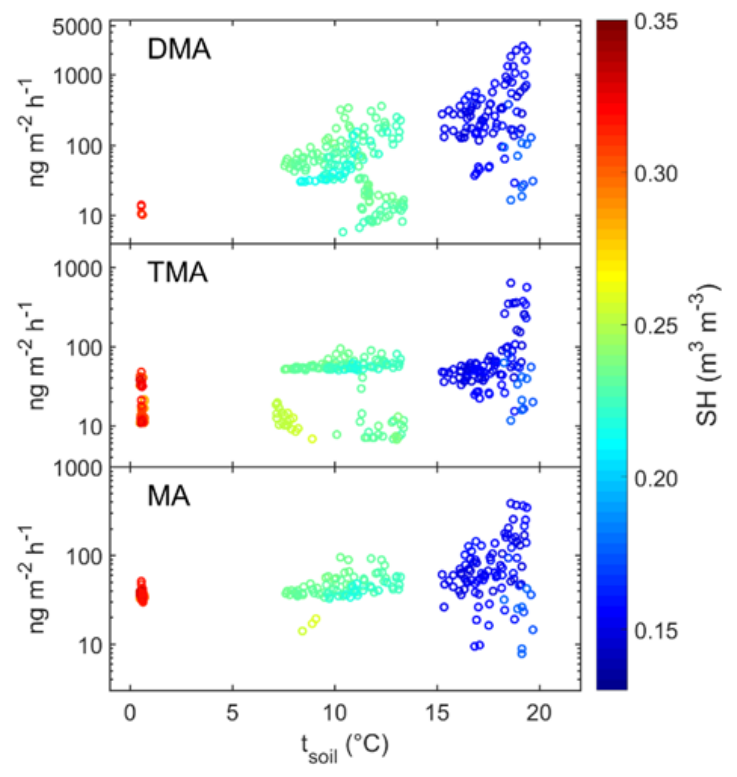

Figure 20. Emission rates of three amines in the chamber as a function of soil surface temperature $\left(\mathrm{t},{ }^{\circ} \mathrm{C}\right)$ and soil surface humidity $\left(\mathrm{SH}, \mathrm{m}^{3} \mathrm{~m}^{-3}\right)$ (color-coded). 


\section{Review of Papers and Author's Contribution}

Paper I presents the chemodiversity of a Scots pine stand in SMEAR II Hyytiälä and discusses its implications for terpene air concentrations and atmospheric models. The chemodiversity and associated emission measurements were conducted from 40 cut branches in the laboratory. The main conclusion of the paper is that the different individual pines indeed have different chemotypes and different chemical emission fingerprints. These results need to be taken into account in atmospheric chemistry modelling. I made the VOC analysis of the cut branches and participated in the writing of the manuscript.

Paper II reports the terpenoid and carbonyl emissions from Norway spruce during a growing season. The presence of chemotypes from six different spruces were tested and observed. I participated in the measurement campaign and contributed in the writing of the manuscript.

Paper III summarizes the first data set with the MARGA instrument in the boreal forest environment detecting inorganic gases and ions from the air, and it compares the results with other observation methods. The variability of the $\mathrm{NH}_{3}, \mathrm{HONO}$ and $\mathrm{HNO}_{3}$ concentrations in the ambient air was determined in four seasons. I participated in the measurements and contributed to the writing of the paper together with Dr. Ulla Makkonen, who had the overall responsibility.

Paper IV introduces a new method, MARGA-MS, targeted for atmospheric amine measurements. The MARGA-MS was used in the boreal forest in in situ measurements of ambient concentrations of amines and ammonia/ammonium, and seasonal and diurnal cycles of these compounds are presented. I developed the method for analysing the amines from air with the MARGA-MS and conducted the measurement campaign in Hyytiälä. I was responsible for writing the manuscript.

Paper V presents the results from amine and guanidine forest floor emission measurements in Hyytiälä. In this paper, the MARGA-MS was connected to a dynamic flow through chamber, and the emission measurements were made in April, May, July and September, about one week per month. I had the main responsibility to conducting the measurements, analysing the data and writing the manuscript. 


\section{Conclusions}

In the introduction of this thesis we specified four main objectives for it. The first one was to characterise BVOC-emissions of Scots Pine and Norway Spruce, and it was fulfilled in Papers I and II, where we measured monoterpene emissions from 40 different Scots Pine and 6 different Norway Spruces. The second objective was to develop a method for in situ, online amine measurements, and it was fulfilled in Paper IV, where we developed MARGA-MS, which we used to measure ambient amine concentrations in boreal forest, fulfilling also partly the $3^{\text {rd }}$ objective. The $3^{\text {rd }}$ objective was to understand the variability of amine and inorganic nitrogen compounds, and these were fulfilled in Paper III-IV, where we observed seasonal and diurnal variation of concentrations for $\mathrm{HONO}$ and $\mathrm{HNO}_{3}$ (Paper III), ammonia and ammonium (Papers III\&IV) and amines (Paper IV). In Paper V, we measured the boreal forest floor and observed emissions of different amines and guanidine, finding out that the boreal forest floor indeed is a source of these compounds, which also fulfilled the $4^{\text {th }}$ objective of this thesis.

SOA studies and atmospheric models often use only one monoterpene, typically $\alpha$-pinene, to represent all monoterpenes and as a descriptive concentration a sum of monoterpene concentrations is commonly used (Friedman and Farmer, 2018). Another simplification is to up-scale from data from a few branches to represent emissions from all the trees (Guenther et al., 2012; Messina et al., 2016). This is problematic, because different monoterpenes have diverse reaction rates and reaction pathways in the atmosphere and one branch with a one specific chemotype does not represent the variability in the monoterpene emission fingerprints of the individual trees (Papers I and II). Although branch-scale emission measurements are necessary for detecting also the most reactive compounds, regional scale measurements are more representative.

In Paper III, MARGA was for the first time used in the boreal forest air measurements. Ammonia, ammonium, $\mathrm{HONO}$ and $\mathrm{HNO}_{3}$ were measured during different seasons, and their seasonal and diurnal behaviour were described. All the gases and ammonium had a maximum ambient concentration in summer. $\mathrm{HNO}_{3}$ and $\mathrm{NH}_{3}$ peaked in the daytime, but HONO peaked in the night, because in the day it reacts with solar radiation to form $\mathrm{OH} \cdot$ radical. Based on the data presented in Paper III, the boreal forest floor was thought to be one source of HONO in the summer time, which agreed with the observations of Su et al. (2011). In other seasons, the HONO-to- $\mathrm{NH}_{\mathrm{x}}$ ratio was closer to the ratio of Kurtenbach et al. (2001), meaning that the results indicated dominance of traffic as the source of HONO during autumn, winter and spring.

Because MARGA had too high detection limits for amine measurements, it was connected to a mass spectrometer and used for ambient amine measurements in Paper IV. The MARGA-MS was also used for amine emission measurements from the forest floor (Paper V). Myllys et al. (2018) noticed in their computational study, that another base, guanidine, could have even better qualities to stabilize sulphuric acid clusters than amines. Therefore, 
in Paper $\mathbf{V}$, we included guanidine in our method and detected emissions of it from the boreal forest floor.

Recently, atmospheric amine concentrations and their sources in boreal forest have been a burning research question (Sellegri et al., 2005; Kieloaho et al., 2013, 2017; Sipilä et al., 2015; Schobesberger et al., 2015). Paper IV helps to fill this knowledge gap by presenting the seasonal and diurnal cycles of amines. Furthermore, Paper $\mathbf{V}$ showed that the soil indeed is one of the amine sources in the boreal forest. Ambient air amine measurements have been conducted in boreal forest several times (Kieloaho et al., 2013; Sipilä et al., 2015; Schobesberger et al., 2015, Paper IV), but still the question of if the amines in the boreal forest have an effect on nucleation remained unanswered. Different measurement years have different environmental conditions, and it would be interesting to study amine concentrations in the boreal forest with different measurement instruments at the same time and with a longer time series expanding over years to study interannual variability.

In this thesis I widened the understanding regarding the composition of reactive trace gases in the atmosphere and their behaviour in boreal forest air by taking advantage of chromatographic measurement methods. To summarise the results, we observed chemodiversity in the emissions of Scots pines (Paper I) and Norway spruces (Paper II) using TD-GC-MS. Using the MARGA instrument we were able to measure seasonal and diurnal behaviour of reactive inorganic compounds $\mathrm{HONO}, \mathrm{HNO}_{3}$ and ammonia/ammonium, for the first time in the boreal environment (Paper III). These measurements gave us the idea to develop a method to measure concentration of amines in the atmosphere. As a follow-up, MARGA-MS was adapted to detect amine and ammonia/ammonium in the ambient air both in gas and aerosol phases (Paper IV). In the next step, the instrument was connected to a dynamic flow through chamber in order to quantify amine and guanidine emissions from the forest floor (Paper V).

The results from these studies can be used for improving atmospheric chemistry and aerosol formation models. The results clearly show the high variability of the biogenic emissions and ambient concentrations of reactive trace gases. Based on the findings it is clear that the boreal forest is also a significant source of reactive trace gases in addition to monoterpenes. The methods developed within the thesis, especially for the volatile organic amines, will be valuable in future atmospheric and other environmental studies enabling compound specific amine measurements with low enough detection limits and relatively high time resolution simultaneously from the gas and aerosol phases. 


\section{References}

Aaltonen, H., Pumpanen, J., Pihlatie, M., Hakola, H., Hellén, H., Kulmala, L., Vesala, T., and Bäck, J.: Boreal pine forest floor biogenic volatile organic compound fluxes peak in early summer and autumn, Agr. Forest Meteorol., 151, 682691,doi:10.1016/j.agrformet.2010.12.010, 2011.

Akyüz, M.: Simultaneous determination of aliphatic and aromatic amines in indoor and outdoor air samples by gas chromatography-mass spectrometry, Talanta, 71, 486-492, 2007.

Almeida, J., Schobesberger, S., Kurten, A., Ortega, I. K., Kupiainen-Maatta, O., Praplan, A. P., Adamov, A., Amorim, A., Bianchi, F., Breitenlechner, M., David, A., Dommen, J., Donahue, N. M., Downard, A., Dunne, E., Duplissy, J., Ehrhart, S., Flagan, R. C., Franchin, A., Guida, R., Hakala, J., Hansel, A.,Heinritzi, M., Henschel, H., Jokinen, T., Junninen, H., Kajos, M., Kangasluoma, J., Keskinen, H., Kupc, A., Kurten, T., Kvashin, A. N., Laaksonen, A., Lehtipalo, K., Leiminger, M., Leppa, J., Loukonen, V., Makhmutov, V., Mathot, S., McGrath, M. J., Nieminen, T., Olenius, T., Onnela, A., Petaja, T., Riccobono, F., Riipinen, I., Rissanen, M., Rondo, L., Ruuskanen, T., Santos, F. D., Sarnela, N., Schallhart, S., Schnitzhofer, R., Seinfeld, J. H., Simon, M., Sipila, M., Stozhkov, Y., Stratmann, F., Tome, A., Trostl, J., Tsagkogeorgas, G., Vaattovaara, P., Viisanen, Y., Virtanen, A., Vrtala, A., Wagner, P. E., Weingartner, E., Wex, H., Williamson, C., Wimmer, D., Ye, P., Yli-Juuti, T., Carslaw, K. S., Kulmala, M., Curtius, J., Baltensperger, U., Worsnop, D. R., Vehkamaki, H., and Kirkby, J.: Molecular Understanding of Sulphuric Acid-Amine Particle Nucleation in the Atmosphere, Nature, 502, 359-363, https://doi.org/10.1038/nature12663, 2013.

Angelino, S., Suess, D. T., and Prather, K. A.: Formation of aerosol particles from reactions of secondary and tertiary alkylamine: characterization by aerosol time-of-flight mass spectrometry, Env iron. Sci. Technol., 35, 3130-3138, 2001.

Atkinson, R. and Arey, J.: Atmospheric degradation ofvolatile organic compounds, Chem. Rev., 103, 4605-4638,doi:10.1021/cr0206420, 2003.

Berndt, T., Jokinen, T., Mauldin, R. L., Petäjä, T., Herrmann, H.,Junninen, H., Paasonen, P., Worsnop, D. R., and Sipilä, M.: Gas-phase ozonolysis of selected olefins: The yield of stabilized criegee intermediate and the reactivity toward SO2, J. Phys.Chem. Lett., 3, 2892-2896, https://doi.org/10.1021/jz301158u, 2012.

Bigg, E. K.: The aerosol in a boreal forest in spring, Tellus B, 53, 510-551, https://doi.org/10.3402/tellusb.v53i4.16626, 2001.

Bourtsoukidis, E., Bonn, B., and Noe, S.: On-line field measurements of BVOC emissions from Norway spruce (Picea abies) at the hemiboreal SMEAR-Estonia site under autumn conditions, Boreal Environ. Res., 19, 153-167, 2014a.

Bourtsoukidis, E., Williams, J., Kesselmeier, J., Jacobi, S., and Bonn, B.: From emissions to ambient mixing ratios: online seasonal field measurements of volatile 
organic compounds overa Norway spruce-dominated forest in central Germany, Atmos. Chem. Phys., 14, 6495-6510, doi:10.5194/acp-14-6495-2014,2014b.

Butterbach-Bahl K., Nemitz E., Zaehle S., Billen B., Boeckx P., Erisman J.W., Garnier J., Upstill-Goddard R., Kreu-zer M., Oenema M., Reis S., Schaap M., Simpson D., de Vries W., Winiwarter W. \& Sutton M.A.: Nitrogen as a threat to the European greenhouse balance. In: Sutton M.A., Howard C., Erisman J.W., Billen G., Bleeker A., Grennfelt P., van Grinsven H. \& Grizzetti B. (eds.), The European nitrogen assessment: sources, effects and policy perspectives, Cambridge University Press, Cambridge, pp. 434-462, 2011.

Cape J.N.: Operation of EMEP 'supersites' in the United Kingdom. Annual report for $2007 . \quad$ Avial-able at http://nora.nerc.ac.uk/8660/2/EMEP_supersite_report_2007N008660CR.pdf, 2009.

Cappellin, L., Algarra Alarcon, A., Herdlinger-Blatt, I., Sanchez, J., Biasioli, F., Martin, S. T., Loreto, F., and McKinney, K. A.: Field observations of volatile organic compound (VOC) exchange in red oaks, Atmos. Chem. Phys., 17, 4189-4207, https://doi.org/10.5194/acp-17-4189-2017, 2017.

Chang, I. H., Lee, D. S., and Ock, S. H.: Condenser-type diffusion denuders for the collection of sulfur dioxide in a cleanroom, Anal. Bioanal. Chem., 375, 456-459, https://doi.org/10.1007/s00216-002-1682-3, 2003.

Claeys, M., Graham, B., Vas, G., Wang, W., Vermeylen, R., Pashyn-ska, V., Cafmeyer, J., Guyon, P., Andreae, M. O., Artaxo, P., and Maenhaut, W.: Formation of Secondary Organic AerosolsThrough Photooxidation of Isoprene, Science, 303, 11731176, 2004.

Cojocariu, C., Kreuzwieser, J., and Rennenberg, H.: Correlation ofshort-chained carbonyls emitted from Picea abies with physio-logical and environmental parameters, New Phytol., 162, 717-727, doi:10.1111/j.1469-8137.2004.01061.x, 2004.

Copolovici, L. and Niinemets, 'U.: Temperature dependencies ofHenry's law constants and octanol/water partition coefficientsfor key plant volatile monoterpenoids, Chemosphere, 61, 1390-1400, 2005.

Dal Maso, M., Kulmala, M., Riipinen, I., Wagner, R., Hussein, T., Aalto, P. P. and Lehtinen, K. E. J.: Formation and growth of fresh atmospheric aerosols: eight years of aerosol size distribution data from SMEAR II, Hyytiälä, Finland,Boreal Env. Res.,10: 323-336, 2005.

Dal Maso, M., Liao, L., Wildt, J., Kiendler-Scharr, A., Kleist, E., Tillmann, R., Sipilä, M., Hakala, J., Lehtipalo, K., Ehn, M., Kerminen, V.-M., Kulmala, M., Worsnop, D., and Mentel, T.: A chamber study of the influence of boreal BVOC emissions and sulfuric acid on nanoparticle formation rates at ambient concentrations, Atmos. Chem. Phys., 16, 1955-1970, https://doi.org/10.5194/acp-16-1955-2016, 2016.

David, M., Loubet, B., Cellier, P., Mattsson, M., Schjoerring, J. K., Nemitz, E., Roche, R., Riedo, M., and Sutton, M. A.: Ammonia sources and sinks in an intensively managed 
grassland canopy, Biogeosciences, 6, 1903-1915, https://doi.org/10.5194/bg-6-19032009, 2009.

Dawson, M. L., Perraud, V., Gomez, A., Arquero, K. D., Ezell, M. J., and Finlayson-Pitts, B. J.: Measurement of gas-phase ammonia and amines in air by collection onto an ion exchange resin and analysis by ion chromatography, Atmos. Meas. Tech., 7, 27332744, https://doi.org/10.5194/amt-7-2733-2014, 2014.

Drewnick F., Hings S.S., DeCarlo P.F., Jayne J.T., Gonin M., Fuhrer K., Weimer S., Jimenez J.L., Demerjian K.L., Borrmann S. \& Worsnop D.R.: A new Time-ofFlight Aerosol Mass Spectrometer (ToF-AMS) — instru-ment description and first field deployment. Aerosol Sci. Technol. 39: 637-658, 2005.

Ehn, M., Petäjä, T., Aufmhoff, H., Aalto, P., Hämeri, K., Arnold, F., Laaksonen, A., and Kulmala, M.: Hygroscopic properties of ultrafine aerosol particles in the boreal forest: diurnal variation, solubility and the influence of sulfuric acid, Atmos. Chem. Phys., 7, 211-222, https://doi.org/10.5194/acp-7-211-2007, 2007.

Enghoff, M. B. and Svensmark, H.: The role of atmospheric ions in aerosol nucleation - a review, Atmos. Chem. Phys., 8, 4911-4923, https://doi.org/10.5194/acp-8-4911-2008, 2008 .

FAO: Global forest resources assessment 2010, FAO Forestry paper 163, FAO, ISBN 978 92-5-106654-6, 2010.

Finlayson-Pitts B.J. and Pitts J.N.: Chemistry of the upper and lower atmosphere: theory, experiments and application. Academic Press, San Diego, CA, 2000.

Freshour, N. A., Carlson, K. K., Melka, Y. A., Hinz, S., Panta, B., and Hanson, D. R.: Amine permeation sources characterized with acid neutralization and sensitivities of an amine mass spectrometer, Atmos. Meas. Tech., 7, 3611-3621, https://doi.org/10.5194/amt-73611-2014, 2014.

Friedman, B. and Farmer, D. K.: SOA and gas phase organic acid yields from the sequential photooxidation of seven monoterpenes, Atmos. Environ., 187, 335-345, https://doi.org/10.1016/j.atmosenv.2018.06.003, 2018.

Fäldt, J., Sjöodin, K., Persson, M., Valterova, I., and Borg-Karlson,A.-K.: Correlations between selected monoterpene hydrocarbonsin the xylem of sixPinus(Pinaceae) species, Chemoecology, 11,97-106, 2001.

Ge, X., Wexler, A. S., and Clegg, S. L.: Atmospheric amines - Part II, Thermodynamic properties and gas/particle partitioning, Atmos. Environ., 45, 561-577, https://doi.org/10.1016/j.atmosenv.2010.10.013, 2010.

Ge, X., Wexler, A. S., and Clegg, S. L.: Atmospheric amines - Part I, A review, Atmos. Environ., 45, 524-546, https://doi.org/10.1016/j.atmosenv.2010.10.012, 2011.

Glasoe, W. A., Volz, K., Panta, B., Freshour, N., Bachman, R., Hanson, D.R., McMurry, P.H. and Jen, C.: Sulfuric acid nucleation: An experimental study of the effect of seven bases, J. Geophys. Res. Atmos., 120, 1933-1950, doi:10.1002/2014JD022730, 2015. 
Grabmer, W., Kreuzwieser, J., Wisthaler, A., Cojocariu, C., Graus,M., Rennenberg, H., Steigner, D., Steinbrecher, R., and Hansel, A.: VOC emissions from Norway spruce (Picea abies L. [Karst])twigs in the field - Results of a dynamic enclosure study, Atmos.Environ., 40, S128-S137, 2006.

Guenther, A. B., Jiang, X., Heald, C. L., Sakulyanontvittaya, T., Duhl, T., Emmons, L. K., and Wang, X.: The Model of Emissions of Gases and Aerosols from Nature version 2.1 (MEGAN2.1): an extended and updated framework for modeling biogenic emissions, Geosci. Model Dev., 5, 1471-1492, https://doi.org/10.5194/gmd-5-1471-2012, 2012.

Gutzwiller, L., Arens, F., Baltensperger, U., G“aggeler, H. W., and Ammann, M.: Significance of Semivolatile Diesel Exhaust Organics for Secondary HONO Formation, Environ. Sci. Technol., 36, 677-682, doi:10.1021/es015673b, 2002.

Haapanala, S., Ekberg, A., Hakola, H., Tarvainen, V., Rinne, J., Hellén, H., and Arneth, A.: Mountain birch - potentially large source of sesquiterpenes into high latitude atmosphere, Biogeosciences, 6, 2709-2718, https://doi.org/10.5194/bg-6-2709-2009, 2009.

Hakola, H., Rinne, J., and Laurila, T.: The hydrocarbon emissionrates of Tea-Leaved Willow (Salix phylicifolia), Silver Birch (Betula pendula) and European Aspen (Populus tremula), Atmos. Environ., 32, 1825-1833, 1998.

Hakola, H., Laurila, T., Lindfors, V., Hellén, H., Gaman, A., andRinne, J.: Variation of the VOC emission rates of birch speciesduring the growing season, Boreal Environ. Res., 6, 237-249, 2001.

Hakola, H., Tarvainen, V., Bäck, J., Ranta, H., Bonn, B., Rinne,J., and Kulmala, M.: Seasonal variation of mono- and sesquiter-pene emission rates of Scots pine, Biogeosciences, 3, 93-101,doi:10.5194/bg-3-93-2006, 2006.

Hakola, H., Hellén, H., Tarvainen, V., Bäck, J., Patokoski, J. and Rinne, J.: Annual variations of atmospheric VOC concentrations in a boreal forest, Boreal Env. Res. 14: 722-730, 2009.

Hakola, H., Hellén, H., Hemmilä, M., Rinne, J., and Kulmala, M.: In situ measurements of volatile organic compounds in a boreal forest, Atmos. Chem. Phys., 12, 11665-11678, https://doi.org/10.5194/acp-12-11665-2012, 2012.

Hansel, A., Jordan, A., Warneke, C., Holzinger, R., Wisthaler, A., and Lindinger, W.: Proton-transfer-reaction mass spectrometry (PTR-MS): on-line monitoring of volatile organic compounds atvolume mixing ratios of a few pptv, Plasma Sourc. Sci. Technol., 8, 332-336, 1999.

Hanson, D. R., McMurry, P. H., Jiang, J., Tanner, D., and Huey, L. G.: Ambient pressure proton transfer mass spectrometry: detection of amines and ammonia, Environ. Sci. Technol., 45, 8881-8888, 2011.

Hari, P. and Kulmala, M.: Station for measuring ecosystematmosphere relations (SMEAR II), Boreal Environ. Res., 10, 315-322, 2005. 
Hellén, H., Hakola, H., Pystynen, K.-H., Rinne, J., and Haapanala,S.: C2-C10 hydrocarbon emissions from a boreal wetland andforest floor, Biogeosciences, 3, 167-174, doi:10.5194/bg-3-167-2006, 2006.

Hellén, H., Praplan, A. P., Tykkä, T., Ylivinkka, I., Vakkari, V., Bäck, J., Petäjä, T., Kulmala, M., and Hakola, H.: Long-term measurements of volatile organic compounds highlight the importance of sesquiterpenes for the atmospheric chemistry of a boreal forest, Atmos. Chem. Phys., 18, 13839-13863, https://doi.org/10.5194/acp-18-138392018, 2018.

Hemmilä, M.: Vesiliukoisten yhdisteiden määrittäminen ilmakehän pienhiukkasista ja kaasuista, Master thesis (in Finnish), University of Helsinki, Department of Analytical Chemistry, 2013.

Hiltunen, R.: Variation and inheritance of some monoterpenes in Scots pine (Pinus sylvestrisL.), Planta. Med., 28, 315-323, 1975.

Holopainen, J. K., and Gershenzon, J.: Multiple stress factors and the emission of plant VOCs, Trends Plant Sci, 15, 176-184, 10.1016/j.tplants.2010.01.006, 2010.

Holopainen, J. K., and Blande, J. D.: Where do herbivore-induced plant volatiles go?, Front Plant Sci, 4, 10.3389/Fpls.2013.00185, 2013.

Holzke, C., Hoffmann, T., Jaeger, L., Koppmann, R., and Zim-mer, W.: Diurnal and seasonal variation of monoterpene andsesquiterpene emissions from Scots pine (Pinus sylvestrisL.),Atmos. Environ., 40, 3174-3185, 2006.

Huang, R.-J., Li, W.-B., Wang, Y.-R., Wang, Q. Y., Jia, W. T., Ho, K.-F., Cao, J. J., Wang, G. H., Chen, X., EI Haddad, I., Zhuang, Z. X., Wang, X. R., Prévôt, A. S. H., O'Dowd, C. D., and Hoffmann, T.: Determination of alkylamines in atmospheric aerosol particles: a comparison of gas chromatography-mass spectrometry and ion chromatography approaches, Atmos. Meas. Tech., 7, 2027-2035, https://doi.org/10.5194/amt-7-2027-2014, 2014.

Hämeri, K., Väkevä, M., Aalto, P. P., Kulmala, M., Swietlicki, E., Zhou, J., Seidl, W., Becker, E., and O'Dowd, C.: Hygroscopic and CCN properties of aerosol particles in boreal forests, Tellus, 53B, 359-379, 2001.

Ilvesniemi, H., Levula, J., Ojansuu, R., Kolari, P., Kulmala, L., Pumpanen, J., Launiainen, S., Vesala, T., and Nikinmaa, E.: Long-term measurements of the carbon balance of a boreal Scots pine dominated forest ecosystem, Boreal Environ. Res., 14, 731-753, 2009.

IPCC: Climate Change 2013: The Physical Science Basis. Contribution of Working Group I to the Fifth Assessment Report of the Intergovernmental Panel on Climate Change, edited by: Stocker, T. F., Qin, D., Plattner, G.-K., Tignor, M., Allen, S. K., Boschung, J., Nauels, A., Xia, Y., Bex, V., and Midgley, P. M., Cambridge University Press, Cambridge, United Kingdom and New York, NY, USA, 1535 pp., 2013. 
Janson, R., Rosman, K., Karlsson, A., Hansson, H.-C.: Biogenic emissions and gaseous precursors to forest aerosols, Tellus 53B, 423-440, 2001.

Jayne, J.T., Leard, D.C., Zhang, X., Davidovits, P., Smith, K.A., Kolb, C.E. and Worsnop, D.R.:: Development of an aerosol mass spectrometer for size and composition analysis of submicron particles. Aerosol Sci. Technol. 33: 49-70, 2000.

Jimenez, J.L., Jayne, J.T., Shi, Q., Kolb, C.E., Worsnop, D.R., Yourshaw, I., Seinfeld, J.H., Flagan, R.C., Zhang, X., Smith, K.A., Morris, J.W. and Davidovits, P.: Ambi-ent aerosol sampling using the Aerodyne Aerosol Mass Spectrometer. J. Geophys Res. 108(D7), 8425, doi:10.1029/2001JD001213, 2003.

Jokinen, T., Sipilä, M., Kontkanen, J., Vakkari, V., Tisler, P., Du-plissy, E. M., Junninen, H., Kangasluoma, J., Manninen, H. E.,Petäjä, T., and Kulmala, M.: Ion-induced sulfuric acid-ammonia nucleation drives particle formation in coastal Antarctica, Sci.Adv., 4, 9744, https://doi.org/10.1126/sciadv.aat9744, 2018.

Järvi, L., Hannuniemi, H., Hussein, T., Junninen, H., Aalto, P. P., Hillamo, R., M“akel“a, T., Keronen, P., Siivola, E., Vesala, T., and Kulmala, M.: The urban measurement station SMEAR III: Continuous monitoring of air pollution and surface-atmosphere interactions in Helsinki, Finland, Boreal Environ. Res., 14, 86-109, 2009.

Kanakidou, M., Seinfeld, J. H., Pandis, S. N., Barnes, I., Dentener, F. J., Facchini, M. C., Van Dingenen, R., Ervens, B., Nenes, A., Nielsen, C. J., Swietlicki, E., Putaud, J. P., Balkanski, Y., Fuzzi, S., Horth, J., Moortgat, G. K., Winterhalter, R., Myhre, C. E. L., Tsigaridis, K., Vignati, E., Stephanou, E. G., and Wilson, J.: Organic aerosol and global climate modelling: a review, Atmos. Chem. Phys., 5, 1053-1123, https://doi.org/10.5194/acp-5-1053-2005, 2005.

Kansal, A.: Sources and reactivity of NMHCs and VOCs in the atmosphere: A review, J. of Haz. Mat., 166, 1, 17-26 , https://doi.org/10.1016/j.jhazmat.2008.11.048, 2009

Karl, T. R. and Trenberth, K. E.: Modern Global Climate Change, Science, 302, 1719-1723, doi:10.1126/science.1090228, 2003.

Kempf, K., Allwine, E., Westberg, H., Claiborn, C. and Lamb., B.: Hydrocarbon emissions from spruce species using environmental chamber and branch enclosure methods, Atmospheric Environment, 30, 9, 1381-1389, https://doi.org/10.1016/13522310(95)00462-9, 1996.

Kesselmeier, J., and Staudt, M.: Biogenic volatile organic compounds (VOC): An overview on emission, physiology and ecology, J. of Atmos. Chem, 33, 23-88, Doi 10.1023/A:1006127516791, 1999.

Kieloaho, A.-J., Hellén, H., Hakola, H., Manninen, H. E., Nieminen, T., Kulmala, M., and Pihlatie, M.: Gas-phase alkylamines in a boreal Scots pine forest air, Atmos. Environ., 80, 369-377, https://doi.org/10.1016/j.atmosenv.2013.08.019, 2013.

Kieloaho, A.-J., Pihlatie, M., Launiainen, S., Kulmala, M., Riekkola, M.-L., Parshintsev, J., Mammarella, I., Vesala, T., and Heinonsalo, J.: Soil concentrations and soil- 
atmosphere exchange of alkylamines in a boreal Scots pine forest, Biogeosciences, 14 , 1075-1091, https://doi.org/10.5194/bg-14-1075-2017, 2017.

Kirkby J., Curtius J., Almeida J., Dunne E., Duplissy J., Ehrhart S., Franchin A., Gagné S., Ickes L., Kürten A., Kupc A., Metzger A., Riccobono F., Rondo L., Schobes-berger S., Tsagkogeorgas G., Wimmer D., Amorim A., Bianchi F., Breitenlechner M., David A., Dommen J., Downard A., Ehn M., Flagan R.C., Haider S., Hansel A., Hauser D., Jud W., Junninen H., Kreissl F., Kvashin A., Laaksonen A., Lehtipalo K., Lima J., Lovejoy E.R., Makhmutov V., Mathot S., Mikkilä J., Minginette P., Mogo S., Nieminen T., Onnela A., Pereira P., Petäjä T., Schnitzhofer R., Seinfeld J.H., Sipilä M., Stozhkov Y., Stratmann F., Tomé A., Vanhanen J., Viisanen Y., Vrtala A., Wagner P.E., Walther H., Weingartner E., Wex H., Winkler P.M., Carslaw K.S., Worsnop D.R., Baltensperger U. and Kulmala M.: Role of sulphuric acid, ammonia and galactic cosmic rays in atmospheric aerosol nucleation. Nature 476: 429-433, 2011.

Kulmala, M., Pirjola, L. and Mäkelä, J.M.:. Stable sulphate clusters as a source of new atmospheric particles. Nature404: 66-69, 2000.

Kulmala, M., Suni, T., Lehtinen, K. E. J., Dal Maso, M., Boy,M., Reissell, A., Rannik, 'U., Aalto, P., Keronen, P., Hakola, H.,B äck, J., Hoffmann, T., Vesala, T., and Hari, P.: A new feedbackmechanism linking forests, aerosols, and climate, Atmos. Chem.Phys., 4, 557-562,doi:10.5194/acp-4-557-2004, 2004.

Kulmala, M., Kontkanen, J., Junninen, H., Lehtipalo, K., Manninen, H. E., Nieminen, T., Petaja, T., Sipilä, M. J., Schobesberger, S., Rantala, P., Franchin, A., Jokinen, T., Järvinen, E. P., Äijälä, M., Kangasluoma, J. P., Hakala, J. P., Aalto, P. P., Paasonen, P., Mikkilä, J., Vanhanen, J., Aalto, J., Hakola, H., Makkonen, U., Ruuskanen, T., Mauldin III, R., Duplissy, J., Vehkamäki, H., Bäck, J., Kortelainen, A., Riipinen, I., Kurten, T. C., Johnston, M., Smith, J., Ehn, M. K., Mentel, T., Lehtinen, K., Laaksonen, A., Kerminen, V.-M., and Worsnop, D.: Direct observations of atmospheric nucleation, Science, 339, 943-946, https://doi.org/10.1126/science.1227385, 2013.

Kulmala, M., Petäjä, T., Ehn, M., Thornton, J., Sipilä, M., Worsnop, D.R. and Kerminen, V.-M.: Chemistry of atmospheric nucleation: On the recent advances on precursor characterization and atmospheric cluster composition in connection with atmospheric new particle formation, Annu. Rev. Phys. Chem. 65, 21-37, 2014.

Kürten, A., Bergen, A., Heinritzi, M., Leiminger, M., Lorenz, V., Piel, F., Simon, M., Sitals, R., Wagner, A. C., and Curtius, J.: Observation of new particle formation and measurement of sulfuric acid, ammonia, amines and highly oxidized organic molecules at a rural site in central Germany, Atmos. Chem. Phys., 16, 12793-12813, https://doi.org/10.5194/acp-16-12793-2016, 2016

Kurtén, T., Loukonen, V., Vehkamäki, H., and Kulmala, M.: Amines are likely to enhance neutral and ion-induced sulfuric acid-water nucleation in the atmosphere more effectively than ammonia, Atmos. Chem. Phys., 8, 4095-4103, https://doi.org/10.5194/acp-8-4095-2008, 2008. 
Kurtén, T., Petäjä, T., Smith, J., Ortega, I. K., Sipilä, M., Junninen, H., Ehn, M., Vehkamäki, H., Mauldin, L., Worsnop, D. R., and Kulmala, M.: The effect of H2SO4 - amine clustering on chemical ionization mass spectrometry (CIMS) measurements of gasphase sulfuric acid, Atmos. Chem. Phys., 11, 3007-3019, https://doi.org/10.5194/acp11-3007-2011, 2011.

Kurtenbach, R., Becker, K. H., Gomes, J. A. G., Kleffmann, J., Lörzer, J. C., Spittler, M., Wiesen, P., Ackermann, R., Geyer, A., and Platt, U.: Investigations of emissions and heterogeneousformation of HONO in a road traffic tunnel, Atmos. Environ., 35, 3385-3394, 2001.

Kyrö, E.-M., Kerminen, V.-M., Virkkula, A., DalMaso, M., Parshintsev, J., RuízJimenez, J., Forsström, L., Manninen, H.E., Riekkola, M.-L., Heinonen, P. and Kulmala, M.: Antarctic new particle formation from continental biogenic precursors, Atmos. Chem. Phys., 13, 3527-3546, doi:10.5194/acp-13-3527-2013, 2013.

Lehtipalo, K., Rondo, L., Kontkanen, J., Schobesberger, S., Jokinen, T., Sarnela, N., Kurten, A., Ehrhart, S., Franchin, A., Nieminen, T., Riccobono, F., Sipila, M., Yli-Juuti, T., Duplissy, J., Adamov, A., Ahlm, L., Almeida, J., Amorim, A., Bianchi, F., Breitenlechner, M., Dommen, J., Downard, A. J., Dunne, E. M., Flagan, R.C., Guida, R., Hakala, J., Hansel, A., Jud, W., Kangasluoma, J., Kerminen, V.-M., Keskinen, H., Kim, J., Kirkby, J., Kupc, A., Kupiainen-Määttä, O., Laaksonen, A., Lawler, M. J., Leiminger, M., Mathot, S., Olenius, T., Ortega, I. K., Onnela, A., Petäjä,T., Praplan, A., Rissanen, M. P., Ruuskanen, T., Santos, F. D., Schallhart, S., Schnitzhofer, R., Simon, M., Smith, J. M., Tröstl, J., Tsagkogeorgas, G., Tome, A., Vaattovaara, P., Vehkamäki, H., Vrtala, A. E., Wagner, P. E., Williamson, C., Wimmer, D.,Winkler, P. M., Virtanen, A., Donahue, N. M. Carslaw, K. S., Baltensperger, U., Riipinen, I., Curtius, J., Worsnop, D. R., and Kulmala, M.: The effect of acid-base clustering and ions on the growth of atmospheric nano-particles, Nat. Commun., 7, 11594,https://doi.org/10.1038/ncomms11594, 2016.

Lelieveld, J., Butler, T. M., Crowley, J. N., Dillon, T. J., Fischer,H., Ganzeveld, L., Harder, H., Lawrence, M. G., Martinez, M.,Taraborrelli, D., and Williams, J.: Atmospheric oxidation capac-ity sustained by a tropical forest, Nature Chem., 452, 737-740,2008.

Liu, P.S.K., Deng, R., Smith, K.A., Williams, L.R., Jayne, J.T., Canagaratna, M.R., Moore, K., Onasch, T.B., Worsnop, D.R. and Deshler T.: Transmission efficiency of an aerodynamic focusing lens system: comparison of model calculations and laboratory measurements for the Aero-dyne Aerosol Mass spectrometer. Aerosol Sci. Technol.41: 721-733, 2007.

Loukonen, V., Kurtén, T., Ortega, I.K., Vehkamäki, H., Pádua, A.A.H., Sellegri, K. and Kulmala, M.: Enhancing effect of dimethylamine in sulfuric acid nucleation in the presence of water - a computational study, Atmos. Chem. Phys., 10, 4961-4974, doi:10.5194/acp-10-4961-2010, 2010.

Maciag, A., Milakovic, D., Christensen, H. H., Antolovic, V., andKalemba, D.: Essential oil composition and plant-insect relationsin Scots pine (Pinus sylvestrisL.), Scientific 
Bulletin of the Tech-nical University of Lodz 1008, Food Chem. Biotechnol., 71, 7195, 2007.

Makkonen, U., Virkkula, A., Mäntykenttä, J., Hakola, H., Keronen, P., Vakkari, V., and Aalto, P. P.: Semi-continuous gas and inorganic aerosol measurements at a Finnish urban site: comparisons with filters, nitrogen in aerosol and gas phases, and aerosol acidity, Atmos. Chem. Phys., 12, 5617-5631, https://doi.org/10.5194/acp-12-5617$2012,2012$.

Marescau, B., Deshmukh, D. R., Kockx, M., Possemiers, I., Qureshi, I. A., Wiechert, P., De Deyn, P. P. Guanidino Compounds in Serum, Urine, Liver, Kidney, and Brain of Man and Some Ureotelic Animals, Metab. Clin. Exp., 41, 526-532, 1992.

Mauldin III, R. L., Berndt, T., Sipilä, M., Paasonen, P.,Petäjä, T., Kim, S., Kurtén, T., Stratmann, F., Kermi-nen, V.-M., and Kulmala, M.: A new atmospherically relevant oxidant of sulphur dioxide, Nature, 488, 193196,https://doi.org/10.1038/nature11278, 2012.

Messina, P., Lathière, J., Sindelarova, K., Vuichard, N., Granier, C., Ghattas, J., Cozic, A., and Hauglustaine, D. A.: Global biogenic volatile organic compound emissions in the ORCHIDEE and MEGAN models and sensitivity to key parameters, Atmos. Chem. Phys., 16, 14169-14202, https://doi.org/10.5194/acp-16-14169-2016, 2016.

Merikanto J., Napari, I., Vehkamäki, H., Anttila, T. and Kulmala, M.: New parameterization of sulfuric acid-ammonia-water ternary nucleation rates at tropospheric conditions, J. Geophys. Res., 112, D15207, doi:10.1029/2006JD007977, 2007.

Merikanto, J., Spracklen, D. V., Mann, G. W., Pickering, S. J., and Carslaw, K. S.: Impact of nucleation on global CCN, Atmos.Chem. Phys., 9, 8601-8616, doi:10.5194/acp9-8601-2009, 2009.

Mosier, A. R.: Exchange of gaseous nitrogen compounds between agricultural systems and the atmosphere, Plant Soil, 228, 17-2,10.1023/A:1004821205442, 2001.

Myllys, N., Ponkkonen, T., Passananti, M., Elm, J., Vehkamäki, H., Olenius, T. Guanidine: A highly efficient stabilizer in atmospheric new-particle formation. J. Phys. Chem. A, 122, 4717-4729, doi:10.1021/acs.jpca.8b02507, 2018.

Mäki, M., Heinonsalo, J., Hellén, H., and Bäck, J.: Contribution of understorey vegetation and soil processes to boreal forest isoprenoid exchange, Biogeosciences, 14, 10551073, https://doi.org/10.5194/bg-14-1055-2017, 2017.

Nieminen, T., Asmi, A., Dal Maso, M., Aalto, P.P., Keronen, P., Petäjä, T., Kulmala, M. and Kerminen, V.-M.: Trends in atmospheric new-particle formation: 16 years of observations in a boreal forest environment. Boreal Env. Res., 19 (suppl. B): 191-214, 2014.

Orav, A., Kailas, T., and Liiv, M.: Analysis of terpenoid composi-tion of Conifer Needle Oils by Steam Distillation/Extraction, Gas Chromatography and Gas ChromatographyMass Spectrometry,Chromatographia, 43, 215-219, 1996. 
Paasonen, P., Olenius, T., Kupiainen, O., Kurtén, T., Petäjä, T., Birmili, W., Hamed, A., Hu, M., Huey, L. G., Plass-Duelmer, C., Smith, J. N., Wiedensohler, A., Loukonen, V., McGrath, M. J., Ortega, I. K., Laaksonen, A., Vehkamäki, H., Kerminen, V.-M., and Kulmala, M.: On the formation of sulphuric acid - amine clusters in varying atmospheric conditions and its influence on atmospheric new particle formation, Atmos. Chem. Phys., 12, 9113-9133, https://doi.org/10.5194/acp-12-9113-2012, 2012.

Park J. and Lin M.C.: A mass spectrometric study of the NH2 + NO2 reaction. J. Phys. Chem. A 101: 2643-2647, 1997.

Parshintsev, J., Rönkkö, T., Helin, A., Hartonen, K., and Riekkola, M.-L.: Determination of atmospheric amines by on-fiber derivatizationsolid-phase microextraction with 2,3,4,5,6-pentafluoroben-zylchloroformate and 9-fluorenylmethoxycarbonyl chloride, J. Chromatogr. A, 1376, 46-52, 2015.

Peñuelas, J., Asensio, D., Tholl, D., Wenke, K., Rosenkranz,M., Piechulla, B., and Schnitzler, J. P.: Biogenic volatileemissions from the soil, Plant Cell Environ., 37, 1866-1891, doi:10.1111/pce.12340, 2014.

Petäjä, T., Kerminen, V.-M., Hämeri, K., Vaattovaara, P., Joutsensaari, J., Junkermann, W., Laaksonen, A., and Kulmala, M.: Effects of SO2 oxidation on ambient aerosol growth in water and ethanol vapours, Atmos. Chem. Phys., 5, 767-779, https://doi.org/10.5194/acp-5-767-2005, 2005.

Petäjä, T., Mauldin, R.L. III, Kosciuch, E., McGrath, J., Nieminen, T., Paasonen, P., Boy, M., Adamov, A., Kotiaho, T. and Kulmala, M.: Sulfuric acid and $\mathrm{OH}$ concentrations in a boreal forest site. Atmos. Chem. Phys. 9: 7435-7448, 2009.

Petäjä, T., Sipilä, M., Paasonen, P., Nieminen, T., Kurtén, T., Stratmann, F., Vehkamäki, H., Berndt, T. and Kulmala, M.: Experimental observation of strongly bound dimers of sulphuric acid: application to nucleation in the atmosphere, Phys. Rev. Lett. 106, 228302, https://doi.org/10.1103/PhysRevLett.106.228302, 2011.

Place, B. K., Quilty, A. T., Di Lorenzo, R. A., Ziegler, S. E., and VandenBoer, T. C.: Quantitation of 11 alkylamines in atmospheric samples: separating structural isomers by ion chromatography, Atmos. Meas. Tech., 10, 1061-1078, https://doi.org/10.5194/amt-10-1061-2017, 2017.

Rappert, S. and Müller, R.: Microbial degradation of selected odorous substances, Waste Manage., 25, 940-954, 2005.

Riccobono, F., Schobesberger, S., Scott, C. E., Dommen, J., Ortega, I. K., Rondo, L., Almeida, J., Amorim, A., Bianchi, F., Breitenlechner, M., David, A., Downard, A., Dunne, E. M., Duplissy, J., Ehrhart, S., Flagan, R. C., Franchin, A., Hansel, A., Junninen, H., Kajos, M., Keskinen, H., Kupc, A., Kürten, A., Kvashin, A. N., Laaksonen, A., Lehtipalo, K., Makhmutov, V., Mathot, S., Nieminen, T., Onnela, A., Petäjä, T., Praplan, A. P., Santos, F. D., Schallhart, S., Seinfeld, J. H., Sipilä, M., Spracklen, D. V., Stozhkov, Y., Stratmann, F., Tomé, A., Tsagkogeorgas, G., Vaattovaara, P., Viisanen, Y., Vrtala, A., Wagner, P. E., Weingartner, E., Wex, H., Wimmer, D., Carslaw, K. S., Curtius, J., Donahue, N. M., Kirkby, J., Kulmala, 
M., Worsnop, D. R., and Baltensperger, U.: Oxidation Products of Biogenic Emissions Contribute to Nucleation of Atmospheric Particles, Science, 344, 717-721, 2014.

Rinne, J., B äck, J., and Hakola, H.: Biogenic volatile organic com-pound emissions from the Eurasian taiga: current knowledge andfuture directions, Boreal Environ. Res., 14, 807-826, 2009.

Ruiz-Jiminez, J., Hautala, S. S., Parshintsev, J., Laitinen, T., Hartonen, K., Petäjä, T., Kulmala, M., and Riekkola, M.-L.: Aliphatic and aromatic amines in atmospheric aerosol particles: comparison of three techniques in liquid chromatography-mass spectrometry and method development, Talanta, 97, 55-62, 2012.

Ruoho-Airola, T., Leppänen, S. and Makkonen, U.: Changes in the concentration of reduced nitrogen in the air in Finland between 1990 and 2007, Boreal Env. Res.15: 427-436, 2010.

Saikawa, E., Naik, V., Horowitz, L. W. Liu, J. F. and Mauzerall, D. L.: Present and potential future contributions of sulfate, black and organic carbon aerosols from China to global air quality, premature mortality and radiative forcing,Atmos. Environ., 43, 28142822, 2009.

Sarnela, N., Jokinen, T., Duplissy, J., Yan, C., Nieminen, T., Ehn, M., Schobesberger, S., Heinritzi, M., Ehrhart, S., Lehtipalo, K., Tröstl, J., Simon, M., Kürten, A., Leiminger, M., Lawler, M. J., Rissanen, M. P., Bianchi, F., Praplan, A. P., Hakala, J., Amorim, A., Gonin, M., Hansel, A., Kirkby, J., Dommen, J., Curtius, J., Smith, J. N., Petäjä, T., Worsnop, D. R., Kulmala, M., Donahue, N. M., and Sipilä, M.: Measurement-model comparison of stabilized Criegee intermediate and highly oxygenated molecule production in the CLOUD chamber, Atmos. Chem. Phys., 18, 2363-2380, https://doi.org/10.5194/acp-18-2363-2018, 2018.

Sellegri, K., Hanke, M., Umann, B., Arnold, F., and Kulmala, M.: Measurements of organic gases during aerosol formation events in the boreal forest atmosphere during QUEST, Atmos. Chem. Phys., 5, 373-384, https://doi.org/10.5194/acp-5-373-2005, 2005.

Schobesberger, S., Junninen, H., Bianchi, F., Lönn, G., Ehn, M., Lehtipalo, K., Dommen, J., Ehrhart, S., Ortega, I. K., Franchin, A., Nieminen, T., Riccobono, F., Hutterli, M., Duplissy, J., Almeida, J., Amorim, A., Breitenlechner, M., Downard, A. J., Dunne, E. M., Flagan, R. C., Kajos, M., Keskinen, H., Kirkby, J., Kupc, A., Kuerten, A., Kurten, T., Laaksonen, A., Mathot, S., Onnela, A., Praplan, A. P., Rondo, L., Santos, F. D., Schallhart, S., Schnitzhofer, R., Sipilä, M., Tome, A., Tsagkogeorgas, G., Vehkamäki, H., Wimmer, D., Baltensperger, U., Carslaw, K. S., Curtius, J., Hansel, A., Petäjä, T., Kulmala, M., Donahue, N. M. and Worsnop, D. R.: Molecular understanding of atmospheric particle formation from sulfuric acid and large oxidized organic molecules, Proc. Natl. Acad. Sci. U.S.A., 110(43) 17, 223-17, 228, doi:10.1073/pnas.1306973110, 2013.

Schobesberger, S., Franchin, A., Bianchi, F., Rondo, L., Duplissy, J., Kürten, A., Ortega, I. K., Metzger, A., Schnitzhofer, R., Almeida, J., Amorim, A., Dommen, J., Dunne, E. 
M., Ehn, M., Gagné, S., Ickes, L., Junninen, H., Hansel, A., Kerminen, V.-M., Kirkby, J., Kupc, A., Laaksonen, A., Lehtipalo, K., Mathot, S., Onnela, A., Petäjä, T., Riccobono, F., Santos, F. D., Sipilä, M., Tomé, A., Tsagkogeorgas, G., Viisanen, Y., Wagner, P. E., Wimmer, D., Curtius, J., Donahue, N. M., Baltensperger, U., Kulmala, M., and Worsnop, D. R.: On the composition of ammonia-sulfuric-acid ion clusters during aerosol particle formation, Atmos. Chem. Phys., 15, 55-78, https://doi.org/10.5194/acp-15-55-2015, 2015.

Sihto, S.-L., Kulmala, M., Kerminen, V.-M., Dal Maso, M., Petäjä,T., Riipinen, I., Korhonen, H., Arnold, F., Janson, R., Boy, M.,Laaksonen, A., and Lehtinen, K. E. J.: Atmospheric sulphuricacid and aerosol formation: implications from atmospheric mea-surements for nucleation and early growth mechanisms, Atmos.Chem. Phys., 6, 4079-4091, https://doi.org/10.5194/acp-6-4079-2006, 2006.

Silva, P. J., Erupe, M. E., Derek, P., Elias, J., Malloy, Q. G. J., Qi, L., Warren, B., and Cocker III,20D. R.: Trimethylamine as precursor to secondary organic aerosol formation via nitrate radical reaction in the atmosphere, Environ. Sci. Technol., 42, 4689-4696, 2008.

Sintermann, J., Schallhart, S., Kajos, M., Jocher, M., Bracher, A., Muenger, A., Johnson, D., Neftel, A. and Ruuskanen, T.: Trimethylamine emissions in animal husbandry, Biogeosciences, 11, 5073-5085, 10.5194/bg-11-5073-2014, 2014.

Sintermann, J. and Neftel, A.: Ideas and perspectives: on the emission of amines from terrestrial vegetation in the context of new atmospheric particle formation, Biogeosciences, 12, 3225-3240, doi:10.5194/bg-12-3225-2015, 2015.

Sipilä, M., Berndt, T., Petäjä, T., Brus, D., Vanhanen, J., Strat-mann, F., Patokoski, J., Mauldin, R. L., Hyvärinen, A.-P., Lihavainen, H., and Kulmala, M.: The Role of SulfuricAcid in Atmospheric Nucleation, Science, 327, 1243-1246, https://doi.org/10.1126/science.1180315, 2010.

Sipilä, M., Sarnela, N., Jokinen, T., Junninen, H., Hakala, J., Rissanen, M. P., Praplan, A., Simon, M., Kürten, A., Bianchi, F., Dommen, J., Curtius, J., Petäjä, T., and Worsnop, D. R.: Bisulfate - cluster based atmospheric pressure chemical ionization mass spectrometer for high-sensitivity $(<100 \mathrm{ppqV})$ detection of atmospheric dimethyl amine: proof-of-concept and first ambient data from boreal forest, Atmos. Meas. Tech., 8, 4001-4011, https://doi.org/10.5194/amt-8-4001-2015, 2015.

Sjödin, K., Persson, M., Fäldt, J., Ekberg, I., and Borg-Karlson, A.-M.: Occurence and correlations of monoterpene hydrocarbonenantiomers inPinus sylvestrisandPicea abies, J. Chem. Ecol.,26, 1701-1720, 2000.

Slanina, J., ten Brink, H.M., Otjes, R.P., Even, A., Jongejan, P., Khlystov, S., Waijers-Ijpelaan, A., $\mathrm{Hu}, \mathrm{M}$. and $\mathrm{Lu}, \mathrm{Y} .:$ The continuous analysis of nitrate and ammonium in aerosols by the steam jet aerosol collector (SJAC): extension and validation of the methodology. Atmos. Environ. 35: 2319-2330, 2001. 
Staudt, M., Bertin, N., Hansen, U., Seufert, G., Ciccioli, P., Foster,P., Frenzel, B., and Fugit J.-L.: Seasonal and diurnal patterns ofmonoterpene emissions from Pinus pinea, Atmos. Environ., 31,145-156, 1997.

Su, H., Cheng, Y., Oswald, R., Behrendt, T., Trebs, I., Meixner, F., Andreae, M., Cheng, P., Zhang, Y. and Pöschl, U.: Soil nitrite as a source of atmospheric HONO and $\mathrm{OH}$ radicals. Science 333: 1616-1618, 2011.

Swietlicki, E., Hansson, H. -C., Hämeri, K., Svenningsson, B., Massling, A., Mcfiggans, G., McMurry, P. H., Petäjä, T., Tunved, P., Gysel, M., Topping, D., Weingartner, E., Baltensperger, U., Rissler, J., Wiedensohler, A., and Kulmala, M.: Hygroscopic properties of submicrometer atmospheric aerosol particles measured with H-TDMA instruments in various environments - a review, Tellus B: Chemical and Physical Meteorology, 60:3, 432-469, DOI:10.1111/j.1600-0889.2008.00350.x, 2008.

Taipale, R., Sarnela, N., Rissanen, M., Junninen, H., Rantala, P.,Korhonen, F., Siivola, E., Berndt, T., Kulmala, M., Mauldin, R.L., Petaja, T., and Sipila, M.: New instrument for measuring at-mospheric concentrations of non-OH oxidants of $\mathrm{SO}$, BorealEnviron. Res., 19, 55-70, 2014.

Tarvainen, V., Hakola, H., Hellén, H., Bäck, J., Hari, P., and Kulmala, M.: Temperature and light dependence of the VOC emissions of Scots pine, Atmos. Chem. Phys., 5, 989998, doi:10.5194/acp-5-989-2005, 2005.

ten Brink H.M., Otjes R., Jongejan P. and Slanina S.: An instrument for semi-continuous monitoring of the size distribution of nitrate, ammonium, sulphate and chloride in aerosol. Atmos. Environ. 41, 2768-2779, 2007.

Tunved, P., Hansson, H.-C., Kerminen, V.-M., Ström, J., Dal Maso,M., Lihavainen, H., Viisanen, Y., Aalto, P. P., Komppula, M., and Kulmala, M.: High Natural Aerosol Loading over Boreal Forests, Science, 312, 261-263, 2006.

VandenBoer, T. C., Petroff, A., Markovic, M. Z., and Murphy, J. G.: Size distribution of alkyl amines in continental particulate matter and their online detection in the gas and particle phase, Atmos. Chem. Phys., 11, 4319-4332, https://doi.org/10.5194/acp-114319-2011, 2011.

VandenBoer, T. C., Markovic, M. Z., Petroff, A., Czar, M. F., Borduas, N., and Murphy, J. G.: Ion chromatographic separation and quantitation of alkyl methylamines and ethylamines in atmospheric gas and particulate matter using preconcentration and suppressed conductivity detection, J. Chromatogr. A, 1252, 74-83, https://doi.org/10.1016/j.chroma.2012.06.062, 2012.

Van Pilsum, J. F., Martin, R. P., Kito, E., Hess, J. Determination of Creatine, Creatinine, Arginine, Guanidinoacetic Acid, Guanidine, and Methylguanidine in Biological Fluids, J. Biol. Chem., 222, 225-236, 1956.

van Pinxteren, M., Fiedler, B., van Pinxteren, B., Iinuma, Y., Kortzinger, A., and Herrmann, H.: Chemical characterization of sub-micrometer aerosol particles in the tropical 
Atlantic Ocean: marine and biomass burning influences, J. Atmos. Chem., 72, 105-125, https://doi.org/10.1007/s10874-015-9307-3, 2015.

Verriele, M., Plaisance, H., Depelchin, L., Benchabane, S., Locoge, N., and Meunier, G.: Determination of 14 amines in air samples using midget impingers sampling followed by analysis with ion chromatography in tandem with mass spectrometry, J. Environ. Monitor., 14, 402-408, https://doi.org/10.1039/c2em10636a, 2012.

Werdin-Pfisterer, N.R., Kielland, K, and Boone, R.D.; Soil amino acid composition across a boreal forest successional sequence, Soil Biol. Biochem., 41, 1210-1220, https://doi.org/10.1016/j.soilbio.2009.03.001, 2009.

WHO: https://www.who.int/news-room/fact-sheets/detail/ambient-(outdoor)-air-qualityand-health, last access 2 January 2020, 2018.

Wyers, G.P., Otjes, R.P. and Slanina, J.: A continuous-flow denuder for the measurement of ambient concentrations and surface-exchange fluxes of ammonia, Atmos. Environ.t, 27A,2085-2090, https://doi.org/10.1016/0960-1686(93)90280-C, 1993.

Yadzani, R., Nilsson, J. E., and Ericsson, T.: Geograqphical variation in the relative proportion of monoterpenes in cortical oleoresin of Pinus sylvestrisin Sweden, Silvae Genet., 34, 201-208, 1985.

Yan, F., Schubert, S., and Mengel, K.: Soil pH increase due to biological decarboxylation of organic anions, Soil Biol. Biochem., 28, 617-624, 1996.

Yassaa, N., Song, W., Lelieveld, J., Vanhatalo, A., Bäck, J., and Williams, J.: Diel cycles of isoprenoids in the emissions of Norway spruce, four Scots pine chemotypes, and in Boreal forest am-bient air during HUMPPA-COPEC-2010, Atmos. Chem. Phys., 12, 7215-7229, doi:10.5194/acp-12-7215-2012, 2012.

You, Y., Kanawade, V. P., de Gouw, J. A., Guenther, A. B., Madronich, S., SierraHernández, M. R., Lawler, M., Smith, J. N., Takahama, S., Ruggeri, G., Koss, A., Olson, K., Baumann, K., Weber, R. J., Nenes, A., Guo, H., Edgerton, E. S., Porcelli, L., Brune, W. H., Goldstein, A. H., and Lee, S.-H.: Atmospheric amines and ammonia measured with a chemical ionization mass spectrometer (CIMS), Atmos. Chem. Phys., 14, 12181-12194, https://doi.org/10.5194/acp-14-12181-2014, 2014.Zheng, J., Ma, Y., Chen, M., Zhang, Q., Wang, L., Khalizov, A. F., Yao, L., Wang, Z., Wang, X., and Chen, L.: Measurements of atmospheric amines and ammonia using the high resolution time-of-flight chemical ionization mass spectrometry, Atmos. Environ., 102, 249-259, 2015 .

Youn, J.-S., Crosbie, E., Maudlin, L. C., Wang, Z., Sorooshian, A.: Dimethylamine as a major alkyl amine species in particles and cloud water: Observations in semi-arid and coastal regions, Atmos. Environ., 122, 250-258, 2015.

Yu, H., McGraw, R., and Shan-Hu, L.: Effects of amines on formation of sub-3 nm particles and their subsequent growth, Geophys. Res. Lett. 39, L02807, doi:10.1029/2011GL050099, 2012. 
Zbieranowski, A.L. and Aherne, J.: Spatial and tempo-ral concentration of ambient atmospheric ammonia in southern Ontario, Canada, Atmos. Environ. 62: 441-450, 2012.

Zhao, J., Eisele, F. L., Titcombe, M., Kuang, C., and McMurry, P. H.: Chemical ionization mass spectrometric measurements of atmospheric neutral clusters using the cluster-CIMS, J. Geophys. Res., 115, D08205, doi:10.1029/2009JD012606, 2010.

Zhou, Y., Dada, L., Liu, Y., Fu, Y., Kangasluoma, J., Chan, T., Yan, C., Chu, B., Daellenbach, K. R., Bianchi, F., Kokkonen, T., Liu, Y., Kujansuu, J., Kerminen, V.-M., Petäjä, T., Wang, L., Jiang, J., and Kulmala, M.: Variation of size-segregated particle number concentrations in winter Beijing, Atmos. Chem. Phys. Discuss., https://doi.org/10.5194/acp-2019-60, in review, 2019. 
Paper I 



\title{
Chemodiversity of a Scots pine stand and implications for terpene air concentrations
}

\author{
J. Bäck ${ }^{1,2}$, J. Aalto ${ }^{2,3}$, M. Henriksson ${ }^{4}$, H. Hakola ${ }^{4}$, Q. He ${ }^{1}$, and M. Boy ${ }^{1}$ \\ ${ }^{1}$ Department of Physics, University of Helsinki, P.O. Box 64, 00014 University of Helsinki, Finland \\ ${ }^{2}$ Department of Forest Sciences, University of Helsinki, P.O. Box 27, 00014 University of Helsinki, Finland \\ ${ }^{3}$ Hyytiälä Forestry Field Station, Hyytiäläntie 124, 35500 Korkeakoski, Finland \\ ${ }^{4}$ Air Quality Research Unit, Finnish Meteorological Institute, P.O. Box 503, 00101 Helsinki, Finland
}

Correspondence to: J. Bäck (jaana.back@helsinki.fi)

Received: 1 June 2011 - Published in Biogeosciences Discuss.: 26 October 2011

Revised: 22 January 2012 - Accepted: 23 January 2012 - Published: 6 February 2012

\begin{abstract}
Atmospheric chemistry in background areas is strongly influenced by natural vegetation. Coniferous forests are known to produce large quantities of volatile vapors, especially terpenes. These compounds are reactive in the atmosphere, and contribute to the formation and growth of atmospheric new particles.
\end{abstract}

Our aim was to analyze the variability of mono- and sesquiterpene emissions between Scots pine trees, in order to clarify the potential errors caused by using emission data obtained from only a few trees in atmospheric chemistry models. We also aimed at testing if stand history and seed origin has an influence on the chemotypic diversity. The inherited, chemotypic variability in mono- and sesquiterpene emission was studied in a seemingly homogeneous $48 \mathrm{yr}$-old stand in Southern Finland, where two areas differing in their stand regeneration history could be distinguished. Sampling was conducted in August 2009. Terpene concentrations in the air had been measured at the same site for seven years prior to branch sampling for chemotypes.

Two main compounds, $\alpha$-pinene and $\Delta^{3}$-carene formed together $40-97 \%$ of the monoterpene proportions in both the branch emissions and in the air concentrations. The data showed a bimodal distribution in emission composition, in particular in $\Delta^{3}$-carene emission within the studied population. $10 \%$ of the trees emitted mainly $\alpha$-pinene and no $\Delta^{3}$-carene at all, whereas $20 \%$ of the trees where characterized as high $\Delta^{3}$-carene emitters $\left(\Delta^{3}\right.$-carene forming $>80 \%$ of total emitted monoterpene spectrum). An intermediate group of trees emitted equal amounts of both $\alpha$-pinene and
$\Delta^{3}$-carene. The emission pattern of trees at the area established using seeding as the artificial regeneration method differed from the naturally regenerated or planted trees, being mainly high $\Delta^{3}$-carene emitters. Some differences were also seen in e.g. camphene and limonene emissions between chemotypes, but sesquiterpene emissions did not differ significantly between trees. The atmospheric concentrations at the site were found to reflect the species and/or chemodiversity rather than the emissions measured from any single tree, and were strongly dominated by $\alpha$-pinene. We also tested the effect of chemodiversity on modeled monoterpene concentrations at the site and found out that since it significantly influences the distributions and hence the chemical reactions in the atmosphere, it should be taken into account in atmospheric modeling.

\section{Introduction}

Biogenic emissions of volatile organic compounds (BVOC) are significant contributors to air composition in rural areas, and make up roughly $50 \%$ of all atmospheric VOCs (Guenther et al., 1995). BVOCs e.g. influence aerosol growth and formation processes (Claeys et al., 2004; Kulmala et al., 2004; Tunved et al., 2006), and contribute to production and destruction of tropospheric ozone (Atkinson and Arey, 2003), and are thus important factors in atmospheric reactivity. Isoprenoids, such as mono- and sesquiterpenes and isoprene, form a significant proportion of all atmospheric 
reactive BVOCs, and therefore numerous field studies have been conducted to determine their emission rates from vegetation (e.g. Isidorov et al., 1985; Janson, 1992; Tarvainen et al., 2005) and concentrations in the air (e.g. Hakola et al., 2003, 2009).

Monoterpene emission models traditionally use an emission algorithm, where parameters are empirically defined under specific environmental conditions (e.g. Guenther et al., 2006; Sakulyanontvittaya et al., 2008). One of the greatest problems in the empirical approach seems to be in the generalization of emissions into one number, which would describe the variability in emissions over a range of conditions and species. Large seasonal variations exist both in emitted quantities and in the emission composition (e.g. Tarvainen et al., 2005; Holzke et al., 2006), emphasizing the need for a detailed understanding of processes involved, in order to create accurate predictions on emissions and their variations in space and time (Rinne et al., 2009). The empirical algorithms have been recently criticized by Niinemets et al. (2010a, b), based on the missing physico-chemical controls and lack of spatio-temporal resolution in the empirical approach. Monoterpene production is controlled by temperature and light conditions, but also the $\mathrm{CO}_{2}$ concentration and compound volatility influence either the production or diffusion from tissues, thus some process-based models taking into account these dynamic factors have been developed for isoprene and monoterpenes (Niinemets et al., 2002; Bäck et al., 2005; Possell et al., 2005; Arneth et al., 2007; Schurgers et al., 2009).

Boreal coniferous forests are covering vast areas in the northern hemisphere (FAO, 2010), and thus the emissions of BVOCs from these areas play an important role in the atmospheric composition regionally and globally. Among the most important volatile compounds emitted from boreal coniferous forests are monoterpenes and sesquiterpenes, which form a major proportion of the conifer oleoresin (Fäldt et al., 2001) and contribute to the constitutive emissions from trunks, needles and roots. The oleoresin is formed in e.g. in epithelial cells of resin ducts of needles (Fig. 1), and liberated from there in the occasion of a mechanical damage. However, monoterpenes and isoprene are also synthesized in mesophyll cells of conifer needles, and most probably the emissions from mesophyll through stomata form a significant part of the constitutive emissions from needles (Ghirardo et al., 2010). The intra-specific variation of monoterpene blend in e.g. Scots pine oleoresin seems to be quite large (Maciag et al., 2007; Thoss et al., 2007), and distinct chemotypes, i.e. genetically determined monoterpene composition, can be defined from needle essential oils. Already in early 1970's, a clear inherited monoterpene pattern in Scots pine (Pinus sylvestris L.) needle extracts was reported (Hiltunen, 1976). Tarvainen et al. (2005) found that the branch scale emissions of Scots pine individuals were dominated by either $\Delta^{3}$-carene or pinenes (both $\alpha$-pinene and $\beta$-pinene), depending on the location of measurements.

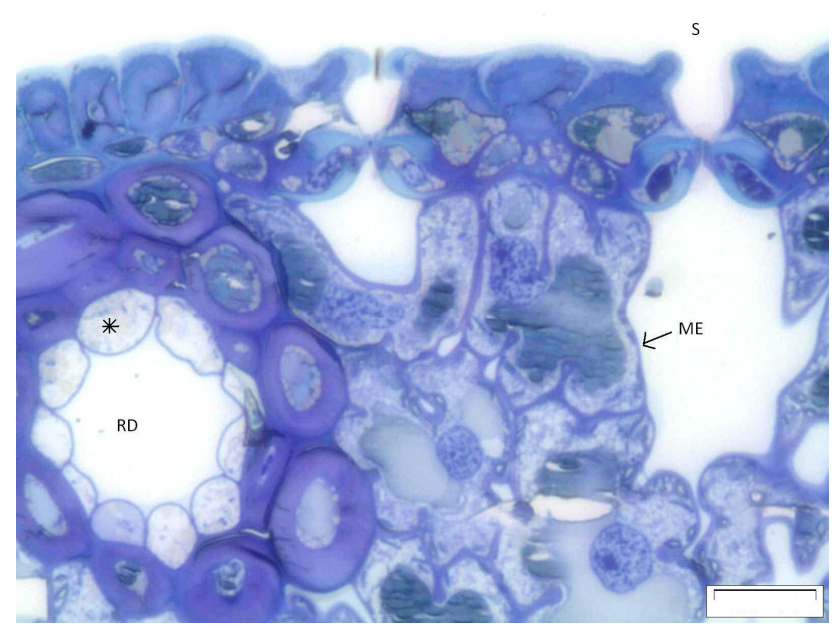

Fig. 1. A light micrograph of a Scots pine needle cross section. The sectioning was done from a resin-embedded needle and the $2 \mu \mathrm{m}$ thick section was stained with Toluidine blue according to Bäck et al. (1994). $\mathrm{RD}=$ resin duct; $\mathrm{ME}=$ mesophyll cell; $\mathrm{S}=$ stoma; $*$ = epithelial cell. $\mathrm{Bar}=50 \mu \mathrm{m}$.

Individual VOCs differ in their atmospheric lifetime and reactivity, and thus it is important to know the composition of the emission blend for modelling the atmospheric chemistry. However, parameterization of atmospheric chemistry models is often done using data from a single tree at a single point of time. Our hypothesis was that this may not be sufficient in describing the impact of the boreal coniferous forest to chemistry above the stand, due to the variation in the inherited emission pattern, chemotype. Therefore we chose to sample branches from trees in a mature Scots pine stand in Southern Finland, where also detailed air chemistry and VOC emission measurements have been conducted over several years. Chemotypic characterization of the stand can reveal the reasons for observed discrepancy between branch scale emissions and above-canopy concentrations and is therefore a key for understanding the implications on air chemistry at the boundary layer.

\section{Methods}

\subsection{Site description and sampling}

The study was carried out at the SMEAR II (Station for Measuring forest Ecosystem - Atmosphere Relations) site in Hyytiälä, Southern Finland ( $61^{\circ} \mathrm{N}, 24^{\circ} \mathrm{E}, 180 \mathrm{~m}$ a.s.1.) in August 2009. The station is situated at a relatively homogenous stand, dominated by 48 yr-old Scots pine with some Norway spruce (Picea abies [L] Karst.) as understorey (Hari and Kulmala, 2005; Ilvesniemi et al., 2009). The proportion of Scots pine is $93 \%$, Norway spruce and deciduous trees (mainly silver and downy birch (Betula pendula [Roth.] and Betula pubescens [Ehrh.]) and European aspen 
(Populus tremula)) are present with proportions of $2 \%$ and $5 \%$, respectively. Within a $200 \mathrm{~m}$ radius from the SMEAR II station, all stands are dominated by Scots pine $(75 \%)$. The Scots pine basal area at the SMEAR II stand is $23 \mathrm{~m}^{2} \mathrm{ha}^{-1}$, and the dominating pines have an average DBH of $19.6 \mathrm{~cm}$. The canopy reaches a height of about $17.5 \mathrm{~m}$. Understorey vegetation is mainly formed from woody shrubs (Vaccinium myrtillus, Vaccinium vitis-idaea and Calluna vulgaris) and mosses (Dicranum polysetum, Pleurozium schreberi). The soil at the stand is mainly podzolic, characterized by thin humus layer and low nitrogen level.

The SMEAR II stand was established mainly by sowing after prescribed burning conducted in 1962. According to old stand management information kept by the Metsähallitus (Administration of states forests) (Hämeenlinnan maakuntaarkisto, 2011), some Scots pine and Norway spruce seedlings have been planted to the SMEAR II stand four years after sowing, in 1966 to fill in gaps. However, sowing was the main regeneration method at the stand. On the contrary, sowing was not used as a regeneration method at all in the adjacent stands, which were regenerated from seeds originating from the close-by mature trees, or by planting with commercially available seedlings. Scots pine is dominating also in most of the surrounding stands, but within the $200 \mathrm{~m}$ radius also some Norway spruce - mixed deciduous stands exist. Within the $200 \mathrm{~m}$ radius the ages of the stands vary from 27 to $85 \mathrm{yr}$ and the proportion of Norway spruce is $15 \%$ and deciduous trees $10 \%$.

We collected branches from 40 pine trees with a systematic sampling scheme (Fig. 2). 25 sample trees were located at the SMEAR II stand and 15 at surrounding pine stands. The middle point of sampling grid was the main mast (length $73 \mathrm{~m}$ ) located in the center of SMEAR II measurement station area. In respect to the main mast the closest sampled trees were at the distance of $5 \mathrm{~m}$ whereas the furthermost ones were $185 \mathrm{~m}$ away. In the selection of sampling plots more emphasis was given to those plots that were located closer to SMEAR II main mast, in order to compare the branch emissions with air concentrations, measured close to the main mast. The probability of the closest plots to be selected was two-fold when compared to the plots that were located farthest off. Between the closest and the farthest plots the probability changed linearly. Branches were collected from upper part of canopy (height 12-14 m), southward facing direction with the help of pole-clippers, and placed immediately in a styrofoam box at $+4^{\circ} \mathrm{C}$. Sampled branches were ca. $20 \mathrm{~cm}$ in length, and included the two most recent age classes of one shoot per tree (about 100-200 needle pairs). The ambient ozone concentrations during sampling ranged from 15 to $35 \mathrm{ppb}$, and those of $\mathrm{NO}_{\mathrm{x}}$ from 0.1 to $1.5 \mathrm{ppb}$.

\subsection{Emission analysis}

The collected branches were stored in cold $\left(<+4^{\circ} \mathrm{C}\right)$ in plastic bags before sampling VOC emissions onto Tenax TA-
Carbopack-B adsorbent in standard laboratory conditions. Emissions were measured immediately after they were transported to the laboratory, not more than 10 days from sampling. By the time of measurement, the cutting-induced resin leakage had ceased and a dry resin plug was formed in the end of the twig. The branches were taken into room temperature 15-40 min before sampling and enclosed in a Teflon bag. We were interested in monoterpene ratios in the emissions of different trees, and thus the analysis was qualitative.

The adsorbent tubes were analysed using a thermodesorption instrument (Perkin-Elmer TurboMatrix 650 ATD) connected to a gas chromatograph-mass spectrometer (PerkinElmer Clarus 600) with HP-1 column $(60 \mathrm{~m}$, i.d. $0.25 \mathrm{~mm})$. The detection limits were $10-200 \mathrm{ng} \mathrm{m}^{-3}$ for most of the compounds. The measured compounds were identified using authentic standards and NIST library.

For analyzing the seasonal variability in monoterpene proportions in Scots pine emission, we also used an old dataset (monthly average emission values from year 2003), reported earlier in Tarvainen et al. (2005).

\subsection{Monoterpene concentrations in the air at the SMEAR II stand}

Air samples were collected between years 2001-2007 for ambient air concentration measurements. The air sampling was done initially above the canopy on the upper level of a scaffolding tower, $10 \mathrm{~m}$ from the main mast. During the measurement period the average Scots pine canopy height in the footprint area increased with $2.1 \mathrm{~m}$, from $15.1 \mathrm{~m}$ to $17.2 \mathrm{~m}$, due to the average annual height growth of $0.3 \mathrm{~m}$ (Ilvesniemi et al., 2009).

The full set of data is reported in Hakola et al. (2009). Here we use only monoterpene data obtained in July-August each year. Samples were collected for $60 \mathrm{~min}$ about three times a week, two samples at a time, and always around noon. Two $\mathrm{MnO}_{2}$-coated copper nets placed in a Teflon holder were employed in front of the sampling tubes for removing ozone from the ambient air. The nets were found to destroy about $80 \%$ of the ozone but leave $\alpha$-pinene, $\beta$-pinene, limonene and $\Delta^{3}$-carene unaffected.

\subsection{Modelling}

The one-dimensional chemistry-transport model SOSA (Model to Simulate the concentrations of Organic vapors and Sulphuric Acid, Boy et al., 2011) was used to investigate the atmospheric relevance of monoterpene chemodiversity for the SMEAR II station in Hyytiälä, Finland.

The meteorology of SOSA is described by a onedimensional version of the SCADIS model (Sogachev et al., 2002; Sogachev and Panferov, 2006). Based on the Reynolds averaged Navier-Stokes (RANS) equations, SCADIS employs a turbulent kinetic energy - specific dissipation closure scheme. The model includes prognostic equations for 

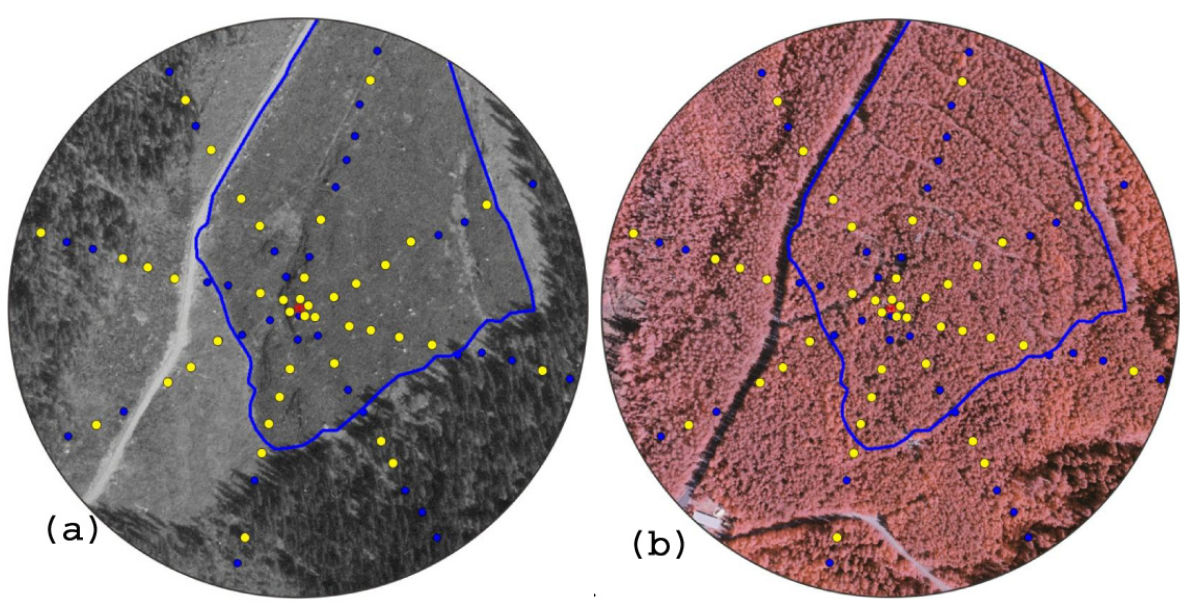

Fig. 2. Aerial photographs of the sample area. Sampling grid is marked with blue (no sample) and yellow (sampled) circles. (a) SMEAR II stand (marked with blue line) and neighbouring stands in 1962; (b) Same stands in 1997. Red dot = mast; diameter of circle $400 \mathrm{~m}$.

these variables and for wind, heat and moisture. Involving a number of parameterizations the model is capable of describing in a realistic manner the physical processes forming the meteorological regime within and above the forest canopy under different environmental conditions (Boy et al., 2011). Measured data from year 2007 at the SMEAR II were used as input and meteorological data (temperature, humidity and wind speed, at 4, 8, 16, 33, 50 and $67 \mathrm{~m}$ heights) were applied for nudging the model variables towards the observations.

The chemistry was calculated using the Kinetic PreProcessor (KPP) (Damian et al., 2002). Most chemical reaction equations were selected from the Master Chemical Mechanism (http://mcm.leeds.ac.uk/MCM/). The photochemistry calculates the photo dissociation constants using data from Atkinson et al. (1992) and spectral irradiance measurements from the SMEAR II station (Boy et al., 2002).

The emissions of organic vapors from the canopy were calculated with a modification of the model MEGAN (Model of Emissions of Gases and Aerosols from Nature), version 2.04 (Guenther et al., 2006). This model, which has been implemented in SOSA, estimates landscape average emission factors for a specific location by combining estimates of plant species composition and representative species-specific emission factors. For each time step, emissions driven by changes in calculated leaf temperature and incident solar radiation on sun and shade leaves at different canopy levels are calculated. We have assumed the landscape to be composed of Scots pine and use standard emission potentials by Hakola et al. (2006). This is a good first order approximation even though it neglects the influence of other plant species in the concentration footprint (e.g. Haapanala et al., 2007). Also 16 different canopy characteristics, such as leaf data together with scattering and reflection coefficients were used to describe the needle forest.

\subsection{Statistics}

The data was tested for chemotypic differences in monoterpene and sesquiterpene emission patterns using nonparametric tests and $k$-means clustering. The tests were conducted for qualitative emission blend data, which was the emission of the emitted compound divided with the sum of emissions of all measured compounds.

$K$-means clustering was conducted using 3 and 4 clusters as input. Two datasets were used for clustering: (1) proportions of the major compounds $\Delta^{3}$-carene and total pinenes $(\alpha$-pinene $+\beta$-pinene) and (2) proportions of all measured compounds. When results of SMEAR II stand and surrounding stands were compared, the number of samples was 25 and 15, respectively. The non-parametric Kruskal-Wallistest was used for testing distributions between groups that were formed using clustering. Correlations between emitted compounds were tested using Pearson correlation coefficient. The non-parametric Mann-Whitney U-test was conducted separately for proportions of $\Delta^{3}$-carene, $\alpha$-pinene and $\beta$-pinene between samples from SMEAR II stand and surrounding stands.

\section{Results}

\subsection{Proportions of mono- and sesquiterpenes in individual Scots pine trees}

The average relative emission content of sampled branches included $\Delta^{3}$-carene and $\alpha$-pinene in almost equal proportions, about $40 \%$ both. The proportion of $\beta$-pinene was little less than $10 \%$. The rest, less than $10 \%$, included all other compounds (in decreasing order): limonene, camphene, isoprene, terpinolene, toluene, benzene, p-cymene, 1,8-cineol, $\beta$-caryophyllene, methylbutenol, alloaromaden- 
Table 1. Averages and standard deviations (sd) for proportions of monoterpenes and sesquiterpenes in total terpenoid emission, differentiated into chemotype groups, and averaged over the whole dataset.

\begin{tabular}{|c|c|c|c|c|c|c|c|c|}
\hline & \multicolumn{2}{|c|}{$\begin{array}{l}\text { Pinene trees } \\
\quad(n=15)\end{array}$} & \multicolumn{2}{|c|}{$\begin{array}{l}\text { Intermediate trees } \\
\qquad(n=17)\end{array}$} & \multicolumn{2}{|c|}{$\begin{array}{c}\text { Carene trees } \\
\quad(n=8)\end{array}$} & \multicolumn{2}{|c|}{$\begin{array}{l}\text { Average of all trees } \\
\qquad(n=40)\end{array}$} \\
\hline & mean & $\mathrm{sd}$ & mean & $\mathrm{sd}$ & mean & sd & mean & sd \\
\hline \multicolumn{9}{|l|}{ MONOTERPENES } \\
\hline$\alpha$-pinene & 0.601 & 0.165 & 0.420 & 0.061 & 0.169 & 0.052 & 0.437 & 0.193 \\
\hline$\Delta^{3}$-carene & 0.144 & 0.104 & 0.445 & 0.080 & 0.764 & 0.062 & 0.396 & 0.246 \\
\hline$\beta$-pinene & 0.171 & 0.173 & 0.053 & 0.043 & 0.018 & 0.013 & 0.090 & 0.125 \\
\hline limonene & 0.037 & 0.066 & 0.019 & 0.021 & 0.003 & 0.001 & 0.023 & 0.043 \\
\hline camphene & 0.018 & 0.009 & 0.022 & 0.015 & 0.008 & 0.005 & 0.018 & 0.013 \\
\hline terpinolene & 0.003 & 0.003 & 0.008 & 0.006 & 0.020 & 0.010 & 0.009 & 0.009 \\
\hline p-cymene & 0.001 & $<0.0005$ & 0.001 & $<0.0005$ & 0.001 & $<0.0005$ & 0.001 & $<0.0005$ \\
\hline 1,8-cineol & $<0.0005$ & $<0.0005$ & 0.001 & 0.001 & 0.001 & 0.001 & 0.001 & 0.001 \\
\hline \multicolumn{9}{|l|}{ SESQUITERPENES $\left(\times 10^{-3}\right)$} \\
\hline$\beta$-caryophyllene & 0.39 & 0.46 & 1.14 & 2.60 & 0.50 & 0.49 & 0.73 & $1 . .74$ \\
\hline alloaromadendr./farnesene & 0.18 & 0.47 & 0.84 & 2.73 & 0.16 & 0.41 & 0.45 & 1.81 \\
\hline$\alpha$-humulene & 0.17 & 0.43 & 0.75 & 2.55 & 0.19 & 0.50 & 0.42 & 1.69 \\
\hline aromadendrene & 0.15 & 0.46 & 0.76 & 2.75 & 0.13 & 0.38 & 0.41 & 1.81 \\
\hline iso-longifolene & 0.13 & 0.36 & 0.62 & 2.14 & 0.16 & 0.43 & 0.35 & 1.42 \\
\hline longicyclene & 0.11 & 0.31 & 0.54 & 1.86 & 0.12 & 0.34 & 0.30 & 1.23 \\
\hline
\end{tabular}

drene/farnesene, bornylacetate, $\alpha$-humulene, aromadendrene, iso-longifolene, longicyclene and nopinone (Table 1). Large differences in relative emission contents between the studied Scots pines were found (Table 1). $\alpha$-pinene and $\Delta^{3}$ carene formed together 40-97\% of the branch monoterpene proportions. Only in one tree the $\beta$-pinene proportion overruled these two major components. Variation was also observed in sesquiterpene composition (Table 1).

The data was analyzed with cluster analysis to reveal potential groupings based on emitted compound spectrum. Three separate clusterings were conducted: (I) three clusters, only proportions of major compounds $\left(\Delta^{3}\right.$-carene and total pinenes $(\alpha$-pinene $+\beta$-pinene) $)$, (II) three clusters, proportions of all measured compounds, (III) four clusters, proportions of all measured compounds. Figure 3 illustrates the average proportions of compounds in 3 clusters based only on the main emitted compounds (type I clustering). This clustering (three clusters, only proportions of major compounds) was used as a basis for further analysis because it is based on the compounds characterizing majority of the variation between trees. These clusters were considered as chemotypes. When all measured compounds were used for dividing trees to 3 clusters (II), the number of high pinene emitters was reduced, and the number of intermediate trees was increased (data not shown). The difference was mainly due to the high $\beta$-pinene emitters shifting from the pinene cluster to the intermediate cluster.

A significant proportion $(20 \%)$ of the pine population could be characterized as high $\Delta^{3}$-carene emitters. The $\Delta^{3}$ - carene emissions of this group were on average $76 \%$ of the total emitted monoterpenes. In minimum their pinene emissions were only one tenth of the $\Delta^{3}$-carene emissions, and the emissions of other monoterpenes were also rather small (on average $<2 \%$ ). Fifteen trees $(37.5 \%)$ emitted mostly $\alpha$-pinene and $\beta$-pinene. From this group, five trees emitted only remnants of $\Delta^{3}$-carene (less than $10 \%$ of total measured emissions), and their pinene emissions were over $90 \%$ of total emission content. In the pinene trees also significant emissions of limonene (ca. $4 \%$ ) and $\beta$-pinene (ca. $17 \%$ ) were measured. However, about half of the trees showed an intermediate emission pattern, with $\Delta^{3}$-carene and $\alpha$-pinene being emitted in almost equal proportions.

$0.01-6.9 \%$ of the total BVOC blend was sesquiterpenes (Table 1). The most abundant sesquiterpene was $\beta$-caryophyllene, which formed over $80 \%$ of the total sesquiterpene emissions in more than half of the trees. The proportion of sesquiterpene emission from trees showing intermediate emission composition was on average threefold when compared to trees showing high proportions of $\Delta^{3}$ carene or pinenes. This difference was caused by a couple of high sesquiterpene emitters among intermediate trees.

The proportion of terpinolene was positively correlated with proportions of $\Delta^{3}$-carene $(r=0.68)$ and $\alpha$-pinene $(r=$ $0.65)$. All sesquiterpenes were strongly intercorrelated $(r>$ $0.9, p<0.01$, Pearson correlation) but this phenomenon was caused by a couple of high sesquiterpene emitters. Correlations between monoterpenes and sesquiterpenes were very weak $(0.39<r>-0.14)$. 


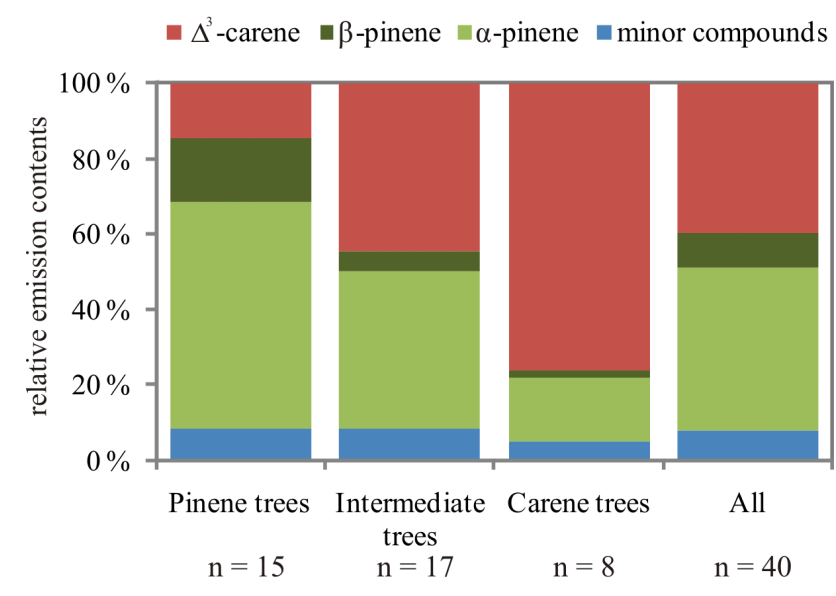

Fig. 3. Average relative emission contents of three clusters. Clustering conducted with the major emitted compounds.

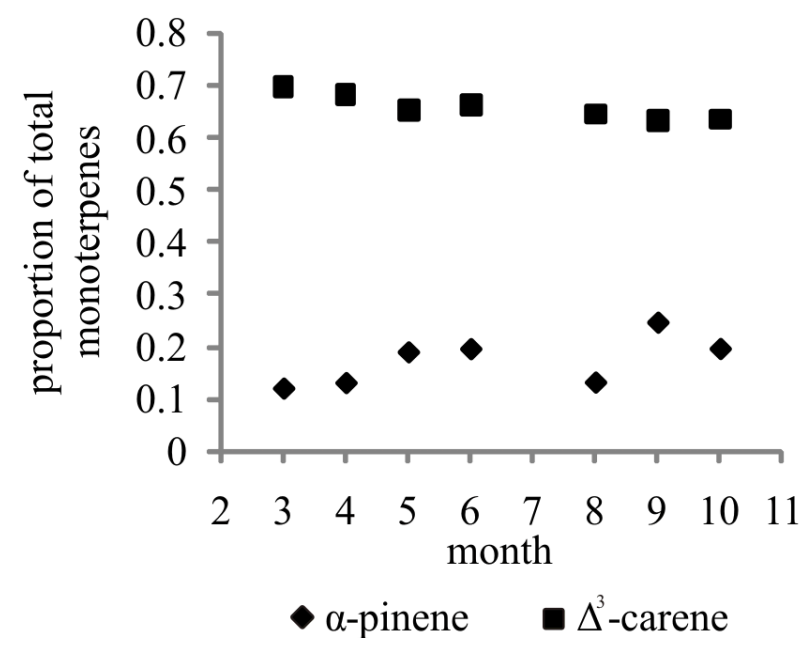

Fig. 4. Variation in proportions (from total monoterpenes) of a-pinene and $\Delta^{3}$-carene in emissions of one tree $\left(\Delta^{3}\right.$-carene chemotype) over one year (2003). Monthly average values $(n=1$ to 10), data from Tarvainen et al. (2005).

We also re-analyzed the emission rates obtained earlier from one " $\Delta^{3}$-carene" chemotype tree (Tarvainen et al., 2005), in order to see if the seasonal emission pattern influences the chemotype (Fig. 4). The results clearly show that even though some changes in relative emission spectrum over the season do occur, the chemotype of an individual tree is not converted from $\Delta^{3}$-carene to pinene-type.

Large variation in relative emission patterns within clusters is evident from Fig. 5. It is clear that especially the group of pinene trees included both trees that emit no $\Delta^{3}$ carene at all and trees that emit some $\Delta^{3}$-carene, whereas all trees, even the highest $\Delta^{3}$-carene emitters, emit some pinenes. Thus it seems that $\alpha$-pinene and $\beta$-pinene always form a part of emissions in Scots pine needles, but that $\Delta^{3}$ carene is a compound that makes the differences between in- dividual trees. When the dataset was divided into four clusters, also the $\beta$-pinene trees were separated from the other clusters (Fig. 6).

Differences in monoterpene distributions between chemotype groups were tested with Kruskal-Wallis test (Table 2). Statistically significant differences in the proportions of $\Delta^{3}$ carene, $\alpha$-pinene and $\beta$-pinene were found, and most of the other monoterpenes also differed between clusters. Only the proportions of 1,8-cineol and sesquiterpenes were not statistically different.

\subsection{Stand-level differences in emissions}

The branch samples were taken from two stands differing in their stand history, namely the SMEAR II and the surrounding stands (see Fig. 2). The average relative monoterpene emissions of trees from the SMEAR II stand and surrounding stands are shown in Fig. 7. Clear differences in proportions of the major compounds $\left(\Delta^{3}\right.$-carene, pinenes) from the SMEAR II and the surrounding stands could be seen. The samples from the SMEAR II stand contained more $\Delta^{3}$-carene and less $\alpha$-pinene than those from the surrounding trees. Differences in the proportions of minor compounds and $\beta$-pinene between the SMEAR II stand and surrounding stands were small (Table 3 ).

The average emission blend in SMEAR II was quite similar to the average emission blend of the trees classified earlier as intermediate, whereas in the surrounding stands the pinene-chemotype seemed to dominate. When distributions of emitted compounds between stands were tested with Mann-Whitney U-test, significant differences in the distributions of $\alpha$-pinene, $\Delta^{3}$-carene, $\beta$-pinene, limonene and $\mathrm{p}$ cymene were found (Table 3 ). Among sample trees from surrounding stands there was only one $\Delta^{3}$-carene tree, whereas SMEAR II stand sample trees included same number of $\Delta^{3}$ carene and pinene trees (Table 3).

\subsection{Air concentrations}

The atmospheric concentrations of monoterpenes at the SMEAR II site were largely dominated by $\alpha$-pinene (Fig. 8) (see also Hakola et al., 2009). The relative proportions of apinene and $\Delta^{3}$-carene remained rather stable over the whole measured period, 2001-2007. Only in 2002 the air concentrations of $\alpha$-pinene and $\Delta^{3}$-carene were close to each other. This is the year when the stand was thinned (see Vesala et al., 2005).

\subsection{Impacts of chemodiversity on atmospheric chemistry modelling}

The emission scheme used in SOSA has been verified recently in two publications by comparing measured and modeled gas phase VOC concentrations (Boy et al., 2011; Mogensen et al., 2011). The results showed good agreement between the model and the measurements, and in this study 


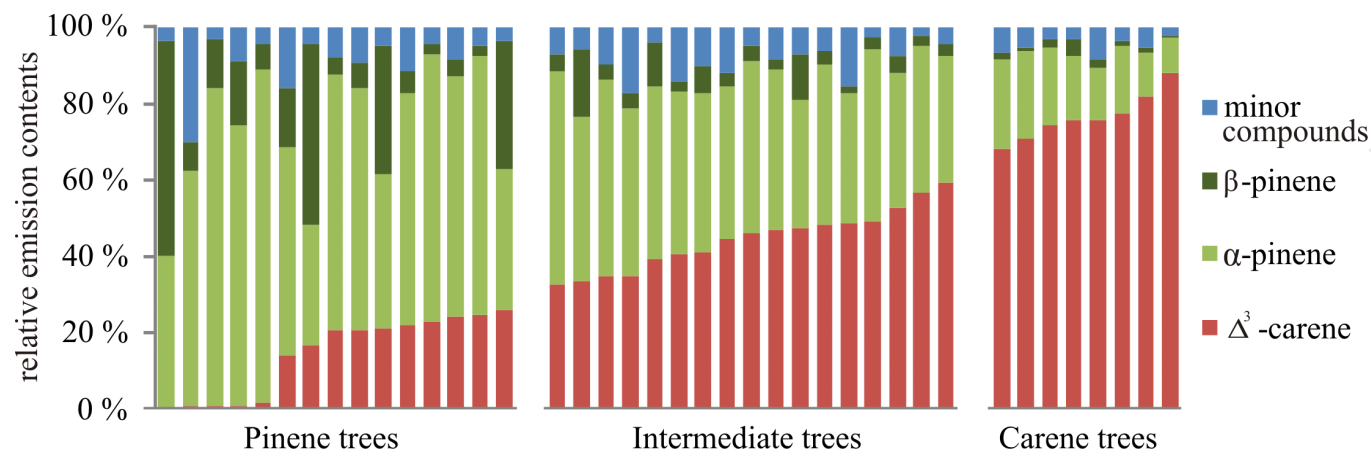

Fig. 5. Relative emission contents of individual trees, clustered as Pinene $(n=15)$, Intermediate $(n=17)$ and Carene trees $(n=8)$. Clustering conducted with the major emitted compounds (type I clustering).

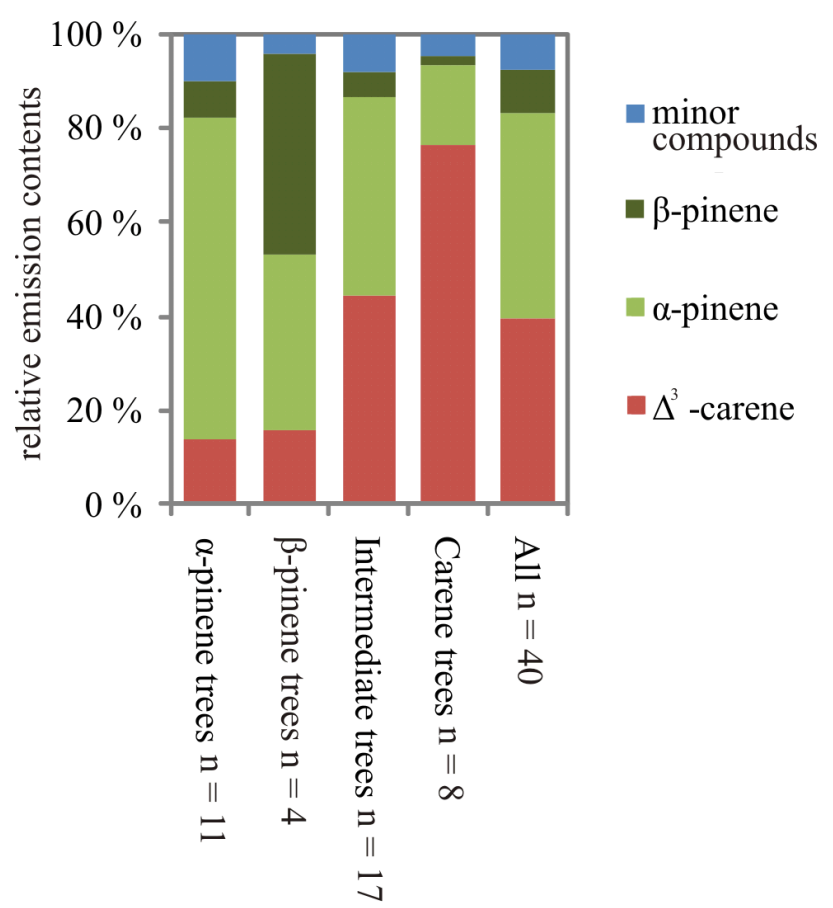

Fig. 6. Average relative emission contents of four clusters (type III clustering). Clusters are named as $\alpha$-pinene trees, $\beta$-pinene trees, intermediate trees and Carene trees.

we will apply SOSA with the same settings and only vary the chemotype-distribution regarding to Table 1. Figure 9 gives the monthly mean concentrations for the sum of monoterpenes at $12 \mathrm{~m}$ height for the year 2007, differentiated between the three chemotypic groups, and also averaged over the whole population. Clear differences, between $30-50 \%$ depending on the month, in the total monoterpene concentrations for the model using $\alpha$-pinene and $\Delta^{3}$-carene chemotypes are visible. The intermediate chemotype is located between the two other groups and the calculated monoterpene concentrations in the intermediate chemotype are very similar to the average for all tree individuals in the population (Fig. 9).

\section{Discussion}

\subsection{Chemodiversity and terpenoid emissions}

In many plants the volatile organic compounds consist of a mixture, where each compound has specific chemical and physical properties and this gives the emissions a complex character. Intraspecies diversity has earlier been characterized from essential oils in plant tissues and cortical oleoresin, where it may be related to resistance towards herbivory, pathogens or some other stresses (e.g. Sjödin et al., 2000; Maciag et al., 2007). We show here that a similar diversity can also be seen in terpene emissions from trees, and that $\Delta^{3}$-carene is clearly the compound that makes the difference between emission blends of individual Scots pine trees. This is in accordance with previous studies on oleoresin composition by e.g. Hiltunen $(1975,1976)$, Yadzani et al. (1985) and Orav et al. (1996). In our study material $\alpha$-pinene and $\beta$ pinene were present in each individual tree, although in some cases in relatively low proportions. However, there were several trees that were emitting practically no $\Delta^{3}$-carene at all. The clear bimodality and grouping of trees into high and low $\Delta^{3}$-carene chemotypes suggests a strong monogenic control for the production of $\Delta^{3}$-carene in pine needles, as was already inferred by Hiltunen et al. (1975). Also in Slash pine (Pinus elliottii Engelm.) the myrcene and $\beta$-pinene composition in the oleoresin of cortical tissues was shown to be bimodal and thus involving only a few genes (Squillace, 1971; Gansel and Squillace, 1976). In our data, the emission blend in pinene chemotype trees contained also other terpene compounds (camphene, limonene) in higher proportions than that of the $\Delta^{3}$-carene -chemotype. Further, the sesquiterpene emission varied also somewhat with chemotype, their proportion of the total emission being highest in the intermediate chemotype.

Previous studies clearly show that the monoterpene composition is influencing the herbivore resistance of plants, and is thus a product of evolutionary development with herbivore pressure. Terpene chemotypes have also been used for species identification in genetic research (e.g. Hiltunen, 
Table 2. Results of the Kruskal-Wallis -test for the proportions of emitted compounds. Statistically significant differences ( $p<0.05)$ between the clusters are marked with ${ }^{* *}$.

\begin{tabular}{lrrrr}
\hline & $\begin{array}{r}\text { Mean rank Pinene trees/ } \\
\text { Intermediate trees/ } \\
\text { Carene trees }\end{array}$ & Test statistic & $p$ & \\
& & & & \\
\hline MONOTERPENES & & & & \\
$\alpha-$ pinene & $29.40 / 20.18 / 4.50$ & 23.692 & $<0.0005$ & $* *$ \\
$\Delta^{3}$-carene & $8.00 / 24.00 / 36.50$ & 33.659 & $<0.0005$ & $* *$ \\
$\beta$-pinene & $28.87 / 19.41 / 7.12$ & 18.302 & $<0.0005$ & $* *$ \\
limonene & $25.93 / 21.35 / 8.50$ & 11.760 & 0.003 & $* *$ \\
camphene & $22.40 / 23.76 / 10.00$ & 8.176 & 0.017 & $* *$ \\
terpinolene & $10.93 / 22.18 / 34.88$ & 22.491 & $<0.0005$ & $* *$ \\
p-cymene & $11.53 / 28.18 / 21.00$ & 16.169 & $<0.0005$ & $* *$ \\
1,8 -cineol & $17.20 / 25.53 / 16.00$ & 5.527 & 0.063 & \\
\hline SESQUITERPENES & & & & \\
$\beta$-caryophyllene & $18.97 / 20.97 / 22.38$ & 0.491 & 0.782 & \\
alloaromadendr./farnesene & $19.73 / 23.47 / 15.62$ & 2.645 & 0.267 & \\
$\alpha$-humulene & $19.33 / 21.85 / 19.81$ & 0.405 & 0.817 & \\
aromadendrene & $22.80 / 19.15 / 19.06$ & 1.904 & 0.386 & \\
iso-longifolene & $20.60 / 21.21 / 18.81$ & 0.230 & 0.891 & \\
longicyclene & $22.00 / 20.74 / 17.19$ & 0.971 & 0.615 & \\
\hline
\end{tabular}

Table 3. Means and standard deviations of proportions of all measured monoterpenes and sesquiterpenes from trees at the SMEAR II stand and at surrounding stands. Results of the Mann-Whitney U-tests for the proportions of different compounds. Statistically significant differences $(p<0.05)$ between the SMEAR II stand and surrounding stands are marked with **. Number of trees in each cluster at SMEAR II stand and surrounding stands.

\begin{tabular}{|c|c|c|c|c|c|c|c|c|}
\hline & \multicolumn{2}{|c|}{$\begin{array}{l}\text { SMEAR II stand } \\
\quad(n=25)\end{array}$} & \multicolumn{2}{|c|}{$\begin{array}{l}\text { Surrounding stands } \\
\qquad(n=15)\end{array}$} & \multirow[t]{2}{*}{$\begin{array}{l}\text { Mean rank SMEAR II/ } \\
\text { Surrounding stands }\end{array}$} & \multirow[t]{2}{*}{$\mathrm{U}$} & \multirow[t]{2}{*}{$p$} & \\
\hline & mean & sd & mean & $\mathrm{sd}$ & & & & \\
\hline \multicolumn{9}{|l|}{ MONOTERPENES } \\
\hline$\alpha$-pinene & 0.39 & 0.19 & 0.51 & 0.17 & $17.68 / 25.20$ & 258 & 0.049 & $* *$ \\
\hline$\Delta^{3}$-carene & 0.47 & 0.24 & 0.28 & 0.20 & $24.08 / 14.53$ & 98 & 0.012 & $* *$ \\
\hline$\beta$-pinene & 0.07 & 0.12 & 0.12 & 0.13 & $17.68 / 25.20$ & 258 & 0.049 & ** \\
\hline limonene & 0.012 & 0.016 & 0.041 & 0.065 & $17.16 / 26.07$ & 271 & 0.020 & $* *$ \\
\hline camphene & 0.016 & 0.013 & 0.021 & 0.012 & $18.60 / 23.67$ & 235 & 0.185 & \\
\hline terpinolene & 0.011 & 0.010 & 0.005 & 0.003 & $23.24 / 15.93$ & 119 & 0.056 & \\
\hline p-cymene & 0.001 & $<0.001$ & 0.001 & $<0.001$ & $23.56 / 15.40$ & 111 & 0.033 & $* *$ \\
\hline 1,8-cineol & 0.001 & 0.001 & $<0.001$ & $<0.001$ & $22.76 / 16.73$ & 131 & 0.114 & \\
\hline \multicolumn{9}{|l|}{ SESQUITERPENES $\left(\times 10^{-3}\right.$} \\
\hline$\beta$-caryophyllene & 0.85 & 2.14 & 0.53 & 0.71 & $20.36 / 20.73$ & 191 & 0.922 & \\
\hline aromadendrene & 0.57 & 2.27 & 0.13 & 0.41 & $20.52 / 20.47$ & 187 & 0.984 & \\
\hline$\alpha$-humulene & 0.57 & 2.12 & 0.16 & 0.43 & $20.32 / 20.80$ & 192 & 0.900 & \\
\hline alloaromadendr./farnesene & 0.61 & $2-27$ & 0.20 & 0.43 & $19.12 / 22.80$ & 222 & 0.327 & \\
\hline iso-longifolene & 0.47 & 1.77 & 0.13 & 0.39 & $20.58 / 20.37$ & 185 & 0.955 & \\
\hline longicyclene & 0.40 & 1.54 & 0.12 & 0.35 & $20.32 / 20.80$ & 192 & 0.896 & \\
\hline Number of Carene trees & \multicolumn{2}{|r|}{7} & \multicolumn{2}{|c|}{1} & & & & \\
\hline Number of Intermediate trees & \multicolumn{2}{|c|}{11} & \multirow{2}{*}{\multicolumn{2}{|c|}{6}} & & & & \\
\hline Number of Pinene trees & \multicolumn{2}{|c|}{7} & 8 & & & & & \\
\hline
\end{tabular}




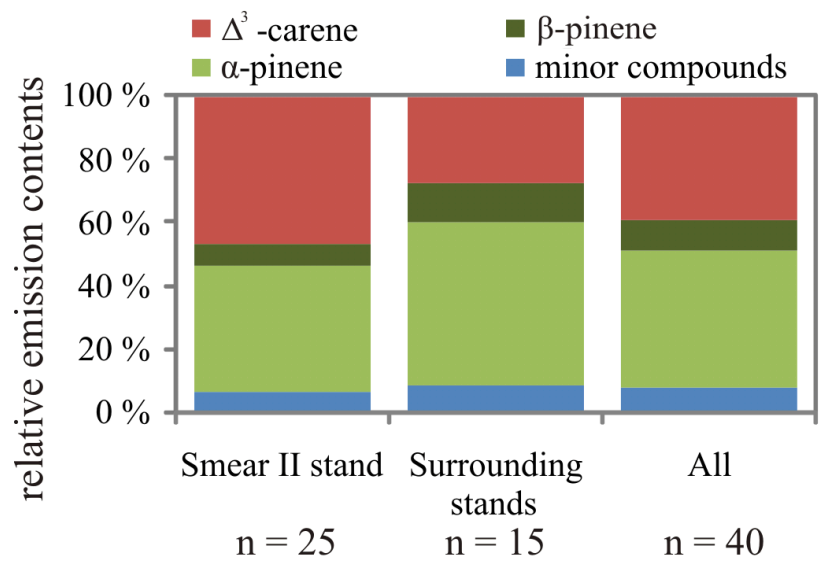

Fig. 7. Average relative emission contents of SMEAR II stand and the surrounding stands, and all 40 sample trees. $n=$ number of trees

1975; Gref and Lindgren, 1984). Chemotypic diversity and bimodal distributions of monoterpenes are seen in oleoresin extracts of many coniferous species, for example Slash pine ( $\beta$-pinene and myrcene, Gansel and Squillace, 1976), Norway spruce $\left(\Delta^{3}\right.$-carene and pinenes, Esteban et al., 1976; Orav et al., 1996), Douglas fir $\left(\Delta^{3}\right.$-carene and pinenes, Latta et al., 2003) and Common juniper (Common juniper $(\alpha-$ pinene and sabinene, Filipowicz et al., 2009).

It has been recognized that the rates of terpenoid emissions from vegetation change significantly with time, and it can be asked if the chemotypic variation also changes with seasons. High quantities of monoterpenes emitted from Scots pine branches have been measured during spring and summer, whereas emissions of sesquiterpenes and some oxygenated compounds are only seen in midsummer period (Tarvainen et al., 2005). The composition of volatiles can also undergo large changes during leaf maturation at least in broad-leaved trees (e.g. Hakola et al., 1998). Our branch material was collected in August, during the maximum emission period, so potential chemotypic variations in the population over time were not studied here. However, based on our earlier results, the chemotype within a branch does not change significantly, although the total emission strength is changing within the season (Fig. 4, see also Tarvainen et al., 2005), and therefore we can conclude that the chemotype is fairly stable over time within a given tree individual. This is consistent with the chemotype being a genetically determined property (e.g. Muona et al., 1986), not influenced by environmental factors.

Emission rates can be influenced by stresses such as mechanical damage (Juuti et al., 1990). In our study, emissions were measured from a cut branch in laboratory, several days after cutting and storage in cold. Our earlier results from emissions after debudding a shoot (Hakola et al., 2006) indicate that high emissions induced after a mechanical damage are sustained only for a few days, and thereafter the emissions decline to a similar level as measured prior wounding.

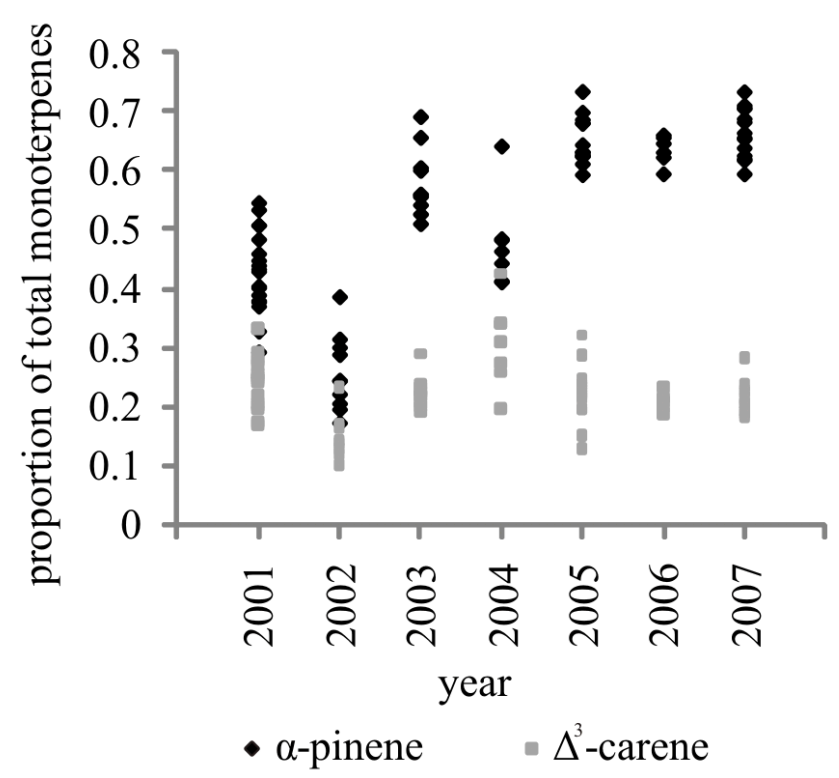

Fig. 8. Summertime (July-August) proportion of $\alpha$-pinene and $\Delta^{3}$ carene from total monoterpenes in the air at SMEAR II between years 2001-2007.

Further, the relative proportions of emitted monoterpenes in the Hakola et al. (2006) study were not influenced by the debudding. Therefore we suggest that the relative monoterpene emissions should not be strongly influenced by the cutting stress in our case, and that these results can therefore be used in estimating the emission variability within a stand.

The emission algorithms used for atmospheric modeling are predicting total emitted quantity rather than the emission quality. However, it is not known, whether the diversity in emission spectrum is also reflected in the total emitted quantities of monoterpenes. According to Latta et al. (2003), the chemodiversity may not influence the total monoterpene quantity in needles, since the regulation of biosynthesis seems to operate at the level of allocation of a limited total pool of monoterpenes among fractions, rather than at the absolute concentrations of individual monoterpenes. In Scots pine the chemodiversity in oleoresin is particularly well documented. A strong heritability in Swedish Scots pines was demonstrated by Baradat et al. (1988) for $\Delta^{3}$-carene, myrcene, limonene and $\beta$-phellandrene, while pinenes and sabinene varied more with environmental factors. The southern pine populations contained more of the high $\Delta^{3}$-carene chemotype trees than northern populations in both Sweden and Finland (Yazdani et al., 1985; Muona et al., 1986; Pohjola, 1993; Manninen et al., 2002), whereas limonene content in pine needles increased towards north (Nerg et al., 1994). This variation was mostly found in natural stands and it was suggested to depend on ecological factors influencing adaptation to differing conditions between south and north (Muona et al., 1986; Pohjola et al., 


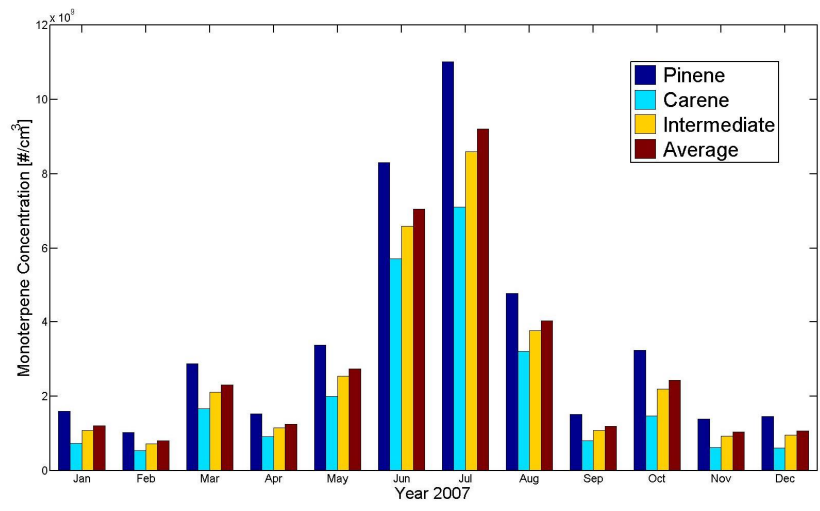

Fig. 9. Modelled monthly mean monoterpene concentrations (molecules $\mathrm{cm}^{-3}$ ) for the year 2007 at SMEAR II using the emissions from Carene, Pinene and Intermediate chemotypes, and the average emission of the population (Table 1).

1993), such as day length and length of growing season. Environmental factors such as light and temperature are accounted for in the present empirical algorithms describing terpene emission rates (e.g. Guenther et al., 2006). Whether this is the case also in Scots pine emissions, remains to be studied in future.

The clustering method was found to be a useful way to divide trees to chemotype groups. It is obvious that the solutions of clustering are highly material dependent: the cutting limits for high and low $\Delta^{3}$-carene emitters can be totally different when clustering is used with some other material. It is worth noticing that both Muona et al. (1986) and Pohjola (1993) used $90 \%$ as a cutting limit for high $\Delta^{3}$ carene emitter, but in our dataset trees with such a high $\Delta^{3}$ carene proportion were not found. However, it seems that $\Delta^{3}$-carene seems to be the compound characterizing the most striking differences between different kinds of emitters, and then the ratio between $\Delta^{3}$-carene and pinenes could be used as an index for a chemotype.

\subsection{Chemodiversity and atmospheric chemistry}

The majority of organic volatiles in background air originate from forest trees (e.g. Guenther et al., 1995; Tarvainen et al., 2007). Scots pine is a predominant conifer in managed and natural forests in large areas of Scandinavia and northern Europe, and thus pine forests have large influence on the chemical composition of background air. Although the chemotypic diversity of Scots pine essential oils has long been known (e.g. Hiltunen et al., 1975), it has largely been ignored in atmospheric studies. This study shows that since the emissions of volatile terpenes from foliage are subject to this wide chemotypic heterogeneity, this diversity has significant impacts on the individual monoterpene concentrations and thus atmospheric chemistry in the boundary layer. Even pure, seemingly homogenous pine stands can exert a variable influence on the chemistry at boundary layer, depending on which chemotypes are present. The different monoterpene concentrations will effect e.g. the radical budget through e.g. higher reaction rates of $\Delta^{3}$-carene compared to $\alpha$-pinene with the hydroxyl (daytime) and the nitrate radical (nighttime). In the case of ozone the ratio of the reaction rates is vice versa, however since the $\mathrm{O}_{3}$ concentrations at SMEAR II are rather low (Boy et al., 2003) the reactions with $\mathrm{O}_{3}$ will produce smaller effects on the monoterpene concentrations than reactions with $\mathrm{OH}$ or nitrate radicals. During more polluted events the reaction with ozone could be more pronounced and merge the total monoterpene concentrations from the pinene and $\Delta^{3}$-carene chemotype groups together.

The implications of chemotypic diversity on modeling the composition of atmosphere are twofold: first, the information currently available on emissions, which is used in air chemistry models seems to be insufficient, when the reactivities of different compounds are taken into account; and second, if also the emission quantity would be affected by emission diversity, then the emission rates based on the screening of only a few trees can be significantly biased. If emission measurements are performed on only one or a few branches/trees, then this may lead into biased conclusions and parameters for such models. The model simulations clearly point out that for understanding the total atmospheric monoterpene concentration, knowledge of the chemotype composition is essential.

Speciated monoterpene emission measurements in field conditions are often conducted using branch enclosures (e.g. Staudt et al., 1997; Tarvainen et al., 2005; Holzke et al., 2006), and emission factors (EFs) are calculated based on these empirical measurements for isoprene and sums of mono- and sesquiterpenes. Due to the laborious sampling and analysis procedure, the number of replicate trees in determining standard emissions at specified conditions is often very limited, and especially the long-term monitoring of compound-speciated branch scale BVOC emissions has been bound to one or a couple of trees. In the current empirical approach, the main external controlling factor for incident monoterpene emissions is temperature (Tingey et al., 1980), although recently also significant light-dependent emissions have been detected from e.g. Scots pine (Shao et al., 2001; Ghirardo et al., 2010). Many caveats have lately been presented towards the original empirical algorithm approach (Niinemets et al., 2010a, b). The compound-specific physico-chemical properties are very variable (Copolovici and Niinemets, 2005) and may influence the EFs (Niinemets et al., 2010a), and since plant emissions are almost always composed of several compounds, the use of a summed emission strength is not sufficient for detailed air chemistry calculations. In longer term, both the quantity and quality of emitted compounds varies diurnally, within the season and along with environmental stressors (e.g. Janson et al., 1999; Tarvainen et al., 2005; Hakola et al., 2006; Holzke et al., 2006), and thus an intrinsic species-specific EF, invariable in time and space is hard to define. 
We propose that chemodiversity is an additional factor, emphasizing the need for deeper understanding of emission dynamics at stand level. The large, chemotypic differences in the composition of emissions in a seemingly homogenous pine stand indicate that branch scale measurements and models based on these may be prone to large experimental biases, and larger scale measurements are necessary for determining the stand emission parameters. Further, not even the current versions of the process-based models can produce compound-specific emission dynamics, and therefore we urgently need a more detailed understanding of the basis of emission variability.

According to our air concentration measurements, abovecanopy concentrations in the site are dominated by $\alpha$-pinene, which on average is three times more abundant than the second most common compound, $\Delta^{3}$-carene (Hakola et al., 2009). The above-canopy concentrations naturally represent very large area, and even with reactive compounds such as monoterpenes, transport distances may be several kilometres (Rinne et al., 2007). Also other tree species than Scots pine inside the footprint area can have an effect on the abovecanopy concentrations. Forests close to the site are dominated by Scots pine, although significant Norway spruce stands are also located in the vicinity. The air concentration measurements were always done on mid day and very close or inside the canopy, which can thus be suggested to represent canopy scale emissions rather well. One important factor is the forestry management, which was potentially seen in the air concentrations during 2002, when thinning of the SMEAR II stand caused a decrease in the proportion of $\alpha$-pinene emission relative to $\Delta^{3}$-carene emission. This suggests that the felled trees were mainly of $\Delta^{3}$-carene chemotype, and a major source for $\Delta^{3}$-carene was the large resin reservoirs which were liberated during felling of the trees.

We also wish to highlight the impact the reaction products of the monoterpenes will have on the formation of secondary organic aerosols. Here we have to consider the still unknown mechanism in the atmospheric nucleation process. Recently Lauros et al. (2010) and Paasonen et al. (2010) claimed that an organic molecule emitted from the biosphere could play a crucial role in the formation of new particles at the SMEAR II site. Until now our understanding is still too limited to make any qualitative statement about this mysterious molecule but in her publication Lauros used the reaction products of all monoterpenes with the hydroxyl radical as a proxy. If only certain monoterpenes are responsible for these reactions, then a chemotype - specific monoterpene distribution can produce significant differences at local or regional scale. The growth of the newly formed particles over the boreal forest is triggered by organic molecules (Tunved et al., 2006) and each monoterpene has a specific aerosol yield leading to different growth rates and cloud condensation nucleus concentrations with important impacts on the radiative aerosol properties. Ebben et al. (2011) show that the organic fraction of submicron aerosol particles collected from
SMEAR II site closely resembles the molecular signature of $\alpha$-pinene, thus confirming the importance of $\alpha$-pinene emissions in the secondary organic aerosol formation processes at this site. A detailed study on the quantitative influence of chemotypic heterogeneity on the $\mathrm{OH}$ - and $\mathrm{NO}_{3}$-radical budget will be presented in further studies.

\subsection{Chemodiversity and stand history}

It was interesting to note that some of the chemotype differences could be attributed to the stand regeneration history even in a rather limited area. The SMEAR II trees showed larger variation in their emission pattern than those in surroundings. There was nearly no high $\Delta^{3}$-carene emitters at the surrounding stands, but at SMEAR II stand there were equal numbers of high and low $\Delta^{3}$-carene emitters. According to the stand history records, the surrounding stands represent mainly local origins, which may be less diverse in their inherited properties than a mixture of trees grown from commercial seeds (such as the SMEAR II stand). The SMEAR II stand is in fact the only stand in the vicinity of SMEAR II measurement station where sowing with commercial seed material has been used as a regeneration method.

During past decades stand regeneration and nursery methods as well as forest tree breeding have been under continuous development in Finland, and as a result of this, for example the sources of seed material have changed. Nowadays majority of seeds used for sowing Scots pine to either nursery or directly to forest after clear cut is collected from specific seed orchards. Those seed orchards have been established in the later part of the 20th century. However, prior to the time when the seed orchards started to produce significant amounts of seed material, seeds for nursery sowings were collected from known high quality trees or stands. At that time, seeds used in nurseries had probably more limited genetic background when compared to seeds used for direct sowing. The main rule in direct sowing was that seeds should not originate too far (either south/north or low/high) from the stand where seeds were sown. Practically no other rules were applied. In a large-scale forestry, large amount of seeds were needed for direct sowing, and they were collected where ever they could be found. This could have lead to large variation in genetic background of seeds.

Muona et al. (1986) reported that in the "plustrees", which are selected particularly for forest tree breeding, there was no geographical pattern related to $\Delta^{3}$-carene emissions. According to both Muona et al. (1986) and Pohjola (1993) north-south variation in the incidence of high $\Delta^{3}$-carene emitters was found in natural stands. Muona et al. (1986) were able to show that favouring other southern features does not explain the lack of geographical variation in the $\Delta^{3}$ carene emissions of plustrees, but this does not preclude a coupling of high $\Delta^{3}$-carene emission and some other feature that is not related to geographical location. Site effects on monoterpene composition of oleoresin with white pine and 
slash pine were very small in several studies (Hanover, 1966; Gansel and Squillace, 1976). Indeed, Gansel and Squillace (1976) concluded that one should avoid characterizing a species by sampling trees in only a few portions of the species range due to the large chemotypic variation.

\section{Conclusions}

The large variation in compound-specific emission patterns influences the stand-level monoterpene concentrations and clear chemotype grouping can be distinguished in Scots pine trees. The chemodiversity implies that at a stand and regional scale, the atmospheric reactivity based on the radical concentrations and the consequent aerosol formation processes evidently also are affected. Since currently the atmospheric chemistry models use parameterizations derived from emission measurements from only one or a few trees, the errors caused by these to the stand-level air chemistry can therefore be high. More comprehensive measurements, process-based modelling involving different chemotypes and populationlevel studies are urgently needed in order to upscale from leaf level to stand or regional level emissions.

A detailed model study on the effects by different chemotypes at the SMEAR II stand for the radicals $\left(\mathrm{OH}\right.$ and $\left.\mathrm{NO}_{3}\right)$ and ozone budget including the consequences for the aerosol formation processes is ongoing and will be published as a follow up manuscript.

Acknowledgements. MSc Janne Levula and the Hämeenlinnan Makunta-arkisto are acknowledged for their help in clarifying the stand history records at the SMEAR II site. The research was supported by the Academy of Finland Center of Excellence program (project number 1118615), the ERC Advanced Grant (project number 227463) and the Graduate school "Atmospheric Composition and Climate Change: From Molecular Processes to Global Observations and Models - Doctoral Programme (ACCC)".

Edited by: H. P. Schmid

\section{References}

Arneth, A., Niinemets, Ü., Pressley, S., Bäck, J., Hari, P., Karl, T., Noe, S., Prentice, I. C., Sera, D., Hickler, T., Wolf, A., and Smith, B.: Process-based estimates of terrestrial ecosystem isoprene emissions: incorporating the effects of a direct $\mathrm{CO}_{2}$-isoprene interaction, Atmos. Chem. Phys., 7, 31-53, doi:10.5194/acp-731-2007, 2007.

Atkinson, R. and Arey, J.: Gas-phase tropospheric chemistry of biogenic volatile organic compounds: a review, Atmos. Environ., 37, 197-219, 2003.

Atkinson, R., Baulch, D. L., Cox, R. A., Hampson Jr., R. F., Kerr, J. A., and Troe, J.: Evaluated kinetic and photochemical data for atmospheric chemistry, Supplement IV, J. Phys. Chem. Ref. Data, 21, 1125-1568, 1992.
Bäck, J., Hari, P., Hakola, H., Juurola, E., and Kulmala, M.: Dynamics of monoterpene emissions in Pinus sylvestris during early spring, Boreal Env. Res. 10, 409-424, 2005.

Baradat, P. and Yadzani, R.: Genetic expression for monoterpenes in clones of Pinus sylvestris grown on different sites, Scand. J. Forest Res., 3, 25-36, 1988.

Boy, M. and Kulmala, M.: The part of the solar spectrum with the highest influence on the formation of SOA in the continental boundary layer, Atmos. Chem. Phys., 2, 375-386, doi:10.5194/acp-2-375-2002, 2002.

Boy, M., Rannik, Ü., Lehtinen, K. E. J., Tarvainen, V., Hakola H., and Kulmala, M.: Nucleation events in the continental PBL long term statistical analysis of aerosol relevant characteristics, J. Geophys. Res., 108, 4667, doi:10.1029/2003JD003838, 2003.

Boy, M., Sogachev, A., Lauros, J., Zhou, L., Guenther, A., and Smolander, S.: SOSA - a new model to simulate the concentrations of organic vapours and sulphuric acid inside the ABL Part 1: Model description and initial evaluation, Atmos. Chem. Phys., 11, 43-51, doi:10.5194/acp-11-43-2011, 2011.

Bäck, J., Neuvonen, S., and Huttunen, S.: Pine needle growth and fine structure after prolonged acid rain treatment in the subarctic, Plant, Cell Environ., 17, 1009-1021, 1994.

Claeys, M., Graham, B., Vas, G., Wang, W., Vermeylen, R., Pashynska, V., Cafmeyer, J., Guyon, P., Andreae, M. O., Artaxo, P., and Maenhaut, W.: Formation of Secondary Organic Aerosols Through Photooxidation of Isoprene, Science, 303, 1173-1176, 2004.

Copolovici, L. and Niinemets, Ü.: Temperature dependencies of Henry's law constants and octanol/water partition coefficients for key plant volatile monoterpenoids, Chemosphere, 61, 13901400, 2005.

Damian, V.: The kinetic pre-processor KPP-a software environment for solving chemical kinetics, Comput. Chem. Eng., 26, 15671579, doi:10.1016/S0098-1354(02)00128-X, 2002.

Ebben, C. J., Martinez, I. S., Shrestha, M., Buchbinder, A. M., Corrigan, A. L., Guenther, A., Karl, T., Petäjä, T., Song, W. W., Zorn, S. R., Artaxo, P., Kulmala, M., Martin, S. T., Russell, L. M., Williams, J., and Geiger, F. M.: Contrasting organic aerosol particles from boreal and tropical forests during HUMPPA-COPEC2010 and AMAZE-08 using coherent vibrational spectroscopy, Atmos. Chem. Phys., 11, 10317-10329, doi:10.5194/acp-1110317-2011, 2011.

Esteban, I., Bergmann, F., Gregorius, H.-R., and Huhtinen, O.: Composition and genetics of monoterpenes from cortical oleoresin of Norway spruce and their significance for clone identifiation, Silvae Genet., 25, 59-66, 1976.

FAO: Global forest resources assessment 2010, FAO Forestry paper 163, FAO, ISBN 978-92-5-106654-6, 2010.

Fäldt, J., Sjödin, K., Persson, M., Valterova, I., and Borg-Karlson, A.-K.: Correlations between selected monoterpene hydrocarbons in the xylem of six Pinus (Pinaceae) species, Chemoecology, 11, 97-106, 2001.

Filipowicz, N., Madanecki, P., Gołebiowski, M., Stepnowski, P., and Ochocka, J. R.: HS-SPME/GC analysis reveals the population variability of terpene contents in Juniperus communis needles, Chem. Biodivers., 6, 2290-2301, 2009.

Gansel, C. R. and Squillace, A. E.: Geographic variation of monoterpene in cortical oleoresin of Slash pine, Silvae Genet., 25, 150-154, 1976. 
Ghirardo, A., Koch, K., Taipale, R., Zimmer, I., Schnitzler, J.-P., and Rinne, J.: Determination of de novo and pool emissions of terpenes from four common boreal/alpine trees by ${ }^{13} \mathrm{CO}_{2}$ labelling and PTR-MS analysis, Plant, Cell Environ., 33, 781-792, doi:10.1111/j.1365-3040.2009.02104.x, 2010.

Gref, R. and Lindgren, D.: The inheritance of pinifolic acid in Scots pine (Pinus sylvestris L.) needles, Silvae Genet., 33, 235-237, 1984.

Guenther, A., Karl, T., Harley, P., Wiedinmyer, C., Palmer, P. I., and Geron, C.: Estimates of global terrestrial isoprene emissions using MEGAN (Model of Emissions of Gases and Aerosols from Nature), Atmos. Chem. Phys., 6, 3181-3210, doi:10.5194/acp-63181-2006, 2006.

Haapanala, S., Rinne, J., Hakola, H., Hellén, H., Laakso, L., Lihavainen, H., Janson, R., O'Dowd, C., and Kulmala, M.: Boundary layer concentrations and landscape scale emissions of volatile organic compounds in early spring, Atmos. Chem. Phys., 7, 1869-1878, doi:10.5194/acp-7-1869-2007, 2007.

Hakola, H., Rinne, J., and Laurila, T.: The hydrocarbon emission rates of tea-leafed willow (Salix phylicifolia), silver birch (Betula pendula) and european aspen (Populus tremula), Atmos. Environ., 32, 1825-1833, 1998.

Hakola, H., Tarvainen, V., Laurila, T., Hiltunen, V., Hellén, H., and Keronen, P.: Seasonal variation of VOC concentrations above a boreal coniferous forest, Atmos. Environ., 37, 1623-1634, 2003.

Hakola, H., Tarvainen, V., Bäck, J., Ranta, H., Bonn, B., Rinne, J., and Kulmala, M.: Seasonal variation of mono- and sesquiterpene emission rates of Scots pine, Biogeosciences, 3, 93-101, doi:10.5194/bg-3-93-2006, 2006.

Hakola, H., Hellén, H., Tarvainen, V., Bäck, J., Patokoski J., and Rinne, J.: Annual variations of atmospheric VOC concentrations in a boreal forest, Boreal Environ. Res., 14, 722-730. 2009.

Hanover, J. W.: Genetics of terpenes. I. Gene control of monoterpene levels in Pinus monticola, Dougl. Heredity, 21, 73-84, doi:10.1038/hdy.1966.5, 1966.

Hari, P. and Kulmala, M.: Station for Measuring EcosystemAtmosphere Relations (SMEAR II), Boreal Environ. Res., 10, 315-322, 2005.

Hiltunen, R.: Variation and inheritance of some monoterpenes in Scots pine (Pinus sylvestris L.), Planta. Med., 28, 315-323, 1975.

Hiltunen, R.: On variation, inheritance and chemical interrelationships of monoterpenes in Scots pine (Pinus sylvestris $\mathrm{L}$.), $\mathrm{PhD}$ thesis, University of Helsinki, Finland. Ann. Acad. Sci. Fenn. Ser. A IV Biol., 208, 1-54, 1976.

Holzke, C., Hoffmann, T., Jaeger, L., Koppmann, R., and Zimmer, W.: Diurnal and seasonal variation of monoterpene and sesquiterpene emissions from Scots pine (Pinus sylvestris L.), Atmos. Environ., 40, 3174-3185, 2006.

Hämeenlinnan maakunta-arkisto, Metsähallituksen Korkeakosken hoitoalueen arkisto: records 33, 34, 35, 38, 39, 51, 54, 55, 58 and 59, 2011.

Ilvesniemi, H., Levula, J., Ojansuu, R., Kolari, P., Kulmala, L., Pumpanen, J., Launiainen, S., Vesala, T., and Nikinmaa, E.: Long-term measurements of the carbon balance of a boreal Scots pine dominated forest ecosystem, Boreal Env. Res. 14, 731-753, 2009.

Isidorov, V. A., Zenkevich, I. G., and Ioffe, B. V.: Volatile organic compounds in the atmosphere of forests, Atmos. Environ., 19, $1-13,1985$.
Janson, R.: Monoterpene concentrations in and above a forest of Scots pine, J. Atmos. Chem., 14, 385-394, 1992.

Janson, R., De Serves, C., and Romero, R.: Emission of isoprene and carbonyl compounds from a boreal forest and wetland in Sweden, Agr. For. Meteorol., 98-99, 671-681, 1999.

Juuti, S., Arey, J., and Atkinson, R.: Monoterpene emission rate measurements from a Monterey pine, J. Geophys. Res., 95, 7515-7519, 1990.

Kulmala, M., Suni, T., Lehtinen, K. E. J., Dal Maso, M., Boy, M., Reissell, A., Rannik, Ü., Aalto, P., Keronen, P., Hakola, H., Bäck, J., Hoffmann, T., Vesala, T., and Hari, P.: A new feedback mechanism linking forests, aerosols, and climate, Atmos. Chem. Phys., 4, 557-562, doi:10.5194/acp-4-557-2004, 2004.

Latta, R. G., Linhart, Y. B., Snyder, M. A., and Lundquist, L.: Patterns of variation and correlation in the monoterpene composition of xylem oleoresin within populations of ponderosa pine, Biochem. Syst. Ecol., 31, 451-465, 2003.

Lauros, J., Sogachev, A., Smolander, S., Vuollekoski, H., Sihto, S.L., Mammarella, I., Laakso, L., Rannik, Ü., and Boy, M.: Particle concentration and flux dynamics in the atmospheric boundary layer as the indicator of formation mechanism, Atmos. Chem. Phys., 11, 5591-5601, doi:10.5194/acp-11-5591-2011, 2011.

Maciag, A., Milakovic, D., Christensen, H. H., Antolovic, V., and Kalemba, D.: Essential oil composition and plant-insect relations in Scots pine (Pinus sylvestris L.), Scientific Bulletin of the Technical University of Lodz 1008, Food Chem. Biotechnol., 71, 7195, 2007.

Manninen, A.-M., Tarhanen, S., Vuorinen, M., and Kainulainen, P.: Comparing the variation of needle and wood terpenoids in Scots pine provenances, J. Chem. Ecol., 28, 211-228, 2002.

Mogensen, D., Smolander, S., Sogachev, A., Zhou, L., Sinha, V., Guenther, A., Williams, J., Nieminen, T., Kajos, M. K., Rinne, J., Kulmala, M., and Boy, M.: Modelling atmospheric OHreactivity in a boreal forest ecosystem, Atmos. Chem. Phys., 11, 9709-9719, doi:10.5194/acp-11-9709-2011, 2011.

Muona, O., Hiltunen, R., Shaw, D. W., and Morén, E.: Analysis of monoterpene variation in natural stands and plustrees of Pinus sylvestris in Finland, Silva Fenn., 20, 1-8, 1986.

Nerg, A., Kainulainen, P., Vuorinen, M., Hanso, M., Holopainen, J. K., and Kurkela, T.: Seasonal and geographical variation of terpenes, resin acids and total phenolics in nursery grown seedlings of Scots pine (Pinus sylvestris L.), New Phytol., 128, 703-713, 1994.

Niinemets, Ü., Seufert, G., Steinbrecher, R., and Tenhunen, J. D.: A model coupling foliar monoterpene emissions to leaf photosynthetic characteristics in Mediterranean evergreen Quercus species, New Phytol., 153, 257-275, 2002.

Niinemets, Ü., Monson, R. K., Arneth, A., Ciccioli, P., Kesselmeier, J., Kuhn, U., Noe, S. M., Peñuelas, J., and Staudt, M.: The leaflevel emission factor of volatile isoprenoids: caveats, model algorithms, response shapes and scaling, Biogeosciences, 7, 18091832, doi:10.5194/bg-7-1809-2010, 2010a.

Niinemets, Ü., Arneth, A., Kuhn, U., Monson, R. K., Peñuelas, J., and Staudt, M.: The emission factor of volatile isoprenoids: stress, acclimation, and developmental responses, Biogeosciences, 7, 2203-2223, doi:10.5194/bg-7-2203-2010, $2010 b$.

Orav, A., Kailas, T., and Liiv, M.: Analysis of terpenoid composition of Conifer Needle Oils by Steam Distillation/Extraction, Gas 
Chromatography and Gas Chromatography-Mass Spectrometry, Chromatographia, 43, 215-219, 1996.

Paasonen, P., Nieminen, T., Asmi, E., Manninen, H. E., Petäjä, T., Plass-Dülmer, C., Flentje, H., Birmili, W., Wiedensohler, A., Hñrrak, U., Metzger, A., Hamed, A., Laaksonen, A., Facchini, M. C., Kerminen, V.-M., and Kulmala, M.: On the roles of sulphuric acid and low-volatility organic vapours in the initial steps of atmospheric new particle formation, Atmos. Chem. Phys., 10, 11223-11242, doi:10.5194/acp-10-11223-2010, 2010.

Pohjola, J.: A Headspace gas chromatographic study on the variation of needle volatile terpenes in Scots pine (Pinus Sylvestris L.), Ph.D. thesis, Pharmacognosy Division, Department of Pharmacy, University of Helsinki, Finland, 1993.

Possell, M., Nicholas. C., and Beerling, D. J.: The effects of glacial atmospheric $\mathrm{CO}_{2}$ concentrations and climate on isoprene emissions by vascular plants, Glob. Change Biol., 11, 60-69, doi:10.1111/j.1365-2486.2004.00889.x, 2005.

Rinne, J., Taipale, R., Markkanen, T., Ruuskanen, T. M., Hellén, H., Kajos, M. K., Vesala, T., and Kulmala, M.: Hydrocarbon fluxes above a Scots pine forest canopy: measurements and modeling, Atmos. Chem. Phys., 7, 3361-3372, doi:10.5194/acp-73361-2007, 2007.

Rinne, J., Bäck, J., and Hakola, H.: Biogenic volatile organic compound emissions from the Eurasian taiga: current knowledge and future directions. Boreal Environ. Res., 14, 807-826, 2009.

Sakulyanontvittaya, T., Guenther, A., Helmig, D., Milford, J., and Wiedinmyer, C.: Secondary organic aerosol from sesquiterpene and monoterpene emissions in the United States, Environ. Sci. Technol., 42, 8784-8790, 2008.

Schurgers, G., Arneth, A., Holzinger, R., and Goldstein, A. H.: Process-based modelling of biogenic monoterpene emissions combining production and release from storage, Atmos. Chem. Phys., 9, 3409-3423, doi:10.5194/acp-9-3409-2009, 2009.

Shao, M., Czapiewski, K.V., Heiden, A.C., Kobel, K., Komenda, M., Koppmann, R., and Wildt, J.: Volatile organic compound emissions from Scots pine: Mechanisms and description by algorithms, J. Geophys. Res., 106, 20483-20491, 2001.

Sjödin, K., Persson, M., Fäldt, J., Ekberg, I., and Borg-Karlson, A.-M.: Occurence and correlations of monoterpene hydrocarbon enantiomers in Pinus sylvestris and Picea abies, J. Chem. Ecol., 26, 1701-1720, 2000.

Sogachev, A. and Panferov, O.: Modification of two-equation models to account for plant drag, Bound.-Lay. Meteorol., 121, 229266, 2006.
Sogachev, A., Menzhulin, G., Heimann, M., and Lloyd, J.: A simple three dimensional canopy planetary boundary layer simulation model for scalar concentrations and fluxes, Tellus B, 54, 784819, 2002.

Squillace, A. E.: Inheritance of monoterpene composition in cortical oleoresin of Slash pine, Forest Sci., 17, 381-387, 1971.

Staudt, M., Bertin, N., Hansen, U., Seufert, G., Ciccioli, P., Foster, P., Frenzel, B., and Fugit J.-L.: Seasonal and diurnal patterns of monoterpene emissions from Pinus pinea, Atmos. Environ., 31, 145-156, 1997.

Tarvainen, V., Hakola, H., Hellén, H., Bäck, J., Hari, P., and Kulmala, M.: Temperature and light dependence of the VOC emissions of Scots pine, Atmos. Chem. Phys., 5, 989-998, doi:10.5194/acp-5-989-2005, 2005.

Tarvainen, V., Hakola, H., Rinne, J., Hellén, H., and Haapanala, S.: Towards a comprehensive emission inventory of terpenoids from boreal ecosystems, Tellus B, 59, 526-534, 2007.

Thoss, V., O'Reilly-Wapstra, J., and Iason, G. R.: Assessment and implications of intraspecific and phenological variability in monoterpenes of Scots pine (Pinus sylvestris) foliage, J. Chem. Ecol., 33, 477-491, 2007.

Tingey, D. T., Manning, M., Grothaus, L. C., and Burns, W. F.: Influence of light and temperature on monoterpene emission rates from Slash Pine, Plant Physiol., 65, 797-801, 1980.

Tunved, P., Hansson, H.-C., Kerminen, V.-M., Ström, J., Dal Maso, M., Lihavainen, H., Viisanen, Y., Aalto, P. P., Komppula, M., and Kulmala, M.: High Natural Aerosol Loading over Boreal Forests, Science, 312, 261-263, 2006.

Yadzani, R., Nilsson, J. E., and Ericsson, T.: Geograqphical variation in the relative proportion of monoterpenes in cortical oleoresin of Pinus sylvestris in Sweden, Silvae Genet., 34, 201-208, 1985.

Vesala, T., Suni, T, Rannik, Ü., Keronen, P., Markkanen, T., Sevanto, S., Grönholm, T., Smolander, S., Kulmala, M., Ilvesniemi, H., Ojansuu, R., Uotila, A., Levula, J., Mäkelä, A., Pumpanen, J., Kolari, P., Kulmala, L., Altimir, N., Berninger, F., Nikinmaa, E., and Hari, P.: Effect of thinning on surface fluxes in a boreal forest, Global Biogeochem. Cy., 19, GB2001, doi:10.1029/2004GB002316, 2005. 



\title{
Terpenoid and carbonyl emissions from Norway spruce in Finland during the growing season
}

\author{
Hannele Hakola $^{1}$, Virpi Tarvainen ${ }^{1}$, Arnaud P. Praplan ${ }^{1}$, Kerneels Jaars ${ }^{2}$, Marja Hemmilä ${ }^{1}$, Markku Kulmala ${ }^{3}$, \\ Jaana Bäck ${ }^{4}$, and Heidi Hellén ${ }^{1}$ \\ ${ }^{1}$ Finnish Meteorological Institute, Atmospheric Composition Unit, P.O. Box 503, 00101 Helsinki, Finland \\ ${ }^{2}$ Unit for Environmental Sciences and Management, North-West University, Potchefstroom, South Africa \\ ${ }^{3}$ Department of Physics, P.O. Box 64, 00014 University of Helsinki, Helsinki, Finland \\ ${ }^{4}$ Department of Forest Ecology, P.O. Box 27, 00014 University of Helsinki, Helsinki, Finland
}

Correspondence to: Hannele Hakola (hannele.hakola@fmi.fi)

Received: 25 August 2016 - Discussion started: 11 October 2016

Revised: 14 February 2017 - Accepted: 15 February 2017 - Published: 8 March 2017

\begin{abstract}
We present spring and summer volatile organic compound (VOC) emission rate measurements from Norway spruce (Picea abies L. Karst) growing in a boreal forest in southern Finland. The measurements were conducted using in situ gas chromatograph with 1 to $2 \mathrm{~h}$ time resolution to reveal quantitative and qualitative short-term and seasonal variability of the emissions. The measurements cover altogether 14 weeks in years 2011, 2014 and 2015. Monoterpene (MT) and sesquiterpene (SQT) emission rates were measured all the time, but isoprene only in 2014 and 2015 and acetone and $\mathrm{C}_{4}-\mathrm{C}_{10}$ aldehydes only in 2015 . The emission rates of all the compounds were low in spring, but MT, acetone, and $\mathrm{C}_{4}-\mathrm{C}_{10}$ aldehyde emission rates increased as summer proceeded, reaching maximum emission rates in July. Late summer mean values (late July and August) were 29, 17, and $33 \mathrm{ng} g(\mathrm{dw})^{-1} \mathrm{~h}^{-1}$ for MTs, acetone, and aldehydes respectively. SQT emission rates increased during the summer and highest emissions were measured in late summer (late summer mean value $\left.84 \mathrm{ng} g(\mathrm{dw})^{-1} \mathrm{~h}^{-1}\right)$ concomitant with highest linalool emissions most likely due to stress effects. The between-tree variability of emission pattern was studied by measuring seven different trees during the same afternoon using adsorbent tubes. Especially the contributions of limonene, terpinolene, and camphene were found to vary between trees, whereas proportions of $\alpha$-pinene $(25 \pm 5 \%)$ and $\beta$-pinene $(7 \pm 3 \%)$ were more stable. Our results show that it is important to measure emissions at canopy level due to irregular emission pattern, but reliable SQT emission data can be measured only from enclosures. SQT emissions
\end{abstract}

contributed more than $90 \%$ of the ozone reactivity most of the time, and about $70 \%$ of the $\mathrm{OH}$ reactivity during late summer. The contribution of aldehydes to $\mathrm{OH}$ reactivity was comparable to that of MT during late summer, 10-30\% most of the time.

\section{Introduction}

The boreal forest is the largest terrestrial biome, forming an almost continuous belt around the Northern Hemisphere. The boreal forest zone is characterized by a short growing season and a limited number of tree species. The most common tree species are Scots pine, Norway spruce, and silver and downy birch and they produce and emit vast amounts of biogenic volatile organic compounds (VOCs) (Bourtsoukidis et al., 2014a, b; Bäck et al., 2012; Cojocariu et al., 2004; Grabmer et al., 2006; Hakola et al., 2001, 2006; Tarvainen et al., 2005; Yassaa et al., 2012). The compounds are mainly isoprene, monoterpenes (MTs), sesquiterpenes (SQTs), and oxygenated volatile organic compounds (OVOCs) (Tarvainen et al., 2007). There is a variety of factors controlling these emissions - both biotic (Pinto-Zevallos et al., 2013; Joutsensaari et al., 2015) and abiotic stress (Vickers et al., 2009; Bourtsoukidis et al., 2012, 2014c) factors can initiate or alter VOC emissions. Abiotic stress factors have been reviewed by Loreto and Schnizler (2010). Terpenes, for example, relieve oxidative and thermal stresses of trees. Many stress factors can also interact and cause addi- 
tive effects (Niinemets, 2010; Holopainen and Gershenzon, 2010). Biotic stresses such as acarid species infestation have been shown to initiate farnesene and linalool emissions in spruce seedlings (Kännaste et al., 2008). Emission potential and composition varies a lot between different tree species (Guenther et al., 2012). However, there is also a lot of variation in the emissions of different individuals of the same tree species. Bäck et al. (2012) showed that Scots pine trees of the same age, growing in the same environment, emit very different monoterpene selections. These so-called different chemotypes cause uncertainties in emission modelling.

In the atmosphere VOCs are oxidized, which affects the tropospheric ozone formation (Chameides et al., 1992) and contributes to the lifetime of methane by consuming hydroxyl radicals. In addition, reaction products of VOCs also participate in the formation and growth of new particles (Tunved et al., 2006). In smog chamber studies secondary organic aerosol (SOA) yields for different hydrocarbons and even for different MTs have been found to vary considerably (Griffin et al., 1999). Jaoui et al. (2013) studied SOA formation from SQT and found that the high reactivity of SQT produced generally high conversion into SOA products. Furthermore, they found that the yields were dependent on the oxidant used and were highest for nitrate radical $\left(\mathrm{NO}_{3}\right)$ reactions. Of the SQT acidic products, only $\beta$-caryophyllinic acid has been observed in ambient samples (Jaoui et al., 2013; Vestenius et al., 2014). Due to their high reactivity, SQT are not usually found in ambient air. Hakola et al. (2012) detected longifolene and isolongifolene in boreal forest air during late summer. Hence, the best way to evaluate the atmospheric impact of SQTs is to measure them from emissions.

In addition to isoprene and MTs and SQTs, plants also emit large amounts of oxygenated compounds - i.e. alcohols, carbonyl compounds, and organic acids (Koppmann and Wildt, 2007). OVOCs containing six carbon atoms $\left(\mathrm{C}_{6}\right)$ are emitted directly by plants often as a result of physical damage (Fall, 1999; Hakola et al., 2001). Saturated aldehydes (hexanal, heptanal, octanal, nonanal, and decanal) have also been found in direct emissions of plants (Wildt et al., 2003) as well as methanol, acetone, and acetaldehyde (Bourtsoukidis et al., 2014b).

In the present study we conducted online gaschromatographic measurements of emissions of MTs and SQTs as well as $\mathrm{C}_{4}-\mathrm{C}_{10}$ saturated aliphatic carbonyls from Norway spruce (Picea abies L. Karst) branches. Although Norway spruce is one of the main forest tree species in central and northern Europe, there are relatively limited amount of data on its emissions (Hakola et al., 2003; Grabmer et al., 2006; Bourtsoukidis et al., 2014a, b; Yassaa et al., 2012). Rinne et al. (2009) identified knowledge gaps concerning VOC emissions from the boreal environment and concluded that there is a lack of knowledge in nonterpenoid emissions from most of the boreal tree species. They also pointed out that chemotypic variations are not well enough understood to be taken into account in emission modelling. To fill this knowledge gap we conducted biogenic volatile organic compound (BVOC) emission measurements from Norway spruce. The online gas chromatograph mass spectrometer (GC-MS) was chosen because in addition to detection of individual MTs it allows sensitive detection of SQTs, which is often difficult to perform under field conditions. The online measurements were considered essential for evaluating the factors affecting emission rates, for example their temperature and light dependence. Our campaigns cover periods of years 2011, 2014, and 2015 during spring and summer, altogether about 14 weeks. In 2015 also carbonyl compounds were added to the measurement scheme, since there are no earlier data of their emissions.

\section{Methods}

\subsection{VOC measurements}

The measurements were conducted at the SMEAR II station (Station for Measuring Forest Ecosystem-Atmosphere Relations; $61^{\circ} 51^{\prime} \mathrm{N}, 24^{\circ} 18^{\prime} \mathrm{E}$; 181 a.s.l.) in Hyytiälä, southern Finland (Hari and Kulmala, 2005) in 2011, 2014, and 2015. The measurements took place in spring/early summer 2011 ( 2 weeks in April, 5 days in May and 3 days in June), spring/summer 2014 (1 week in May, 2 weeks in June and 1 week in July), and summer 2015 (1 week in June and 2 weeks in August) and they were conducted using an in situ gas chromatograph.

Two different trees were measured; tree 1 in 2011 and tree 2 in 2014 and 2015. The selected trees were growing in a managed mixed conifer forest (average tree age ca. 50 years), and located about $5 \mathrm{~m}$ from the measurement container. The height of tree 1 in 2011 was about $10 \mathrm{~m}$ (age about 40 years). The measured branch was a fully sunlit, healthy lower canopy branch pointing towards a small opening at about $2 \mathrm{~m}$ height. In 2014 and 2015 a younger tree (tree 2, ca. $1 \mathrm{~m}$ tall, age ca. 15 years) about $5 \mathrm{~m}$ away from the tree used in 2011 was selected for the study. The branches were placed in a Teflon enclosure and the emission rates were measured using a dynamic flow-through technique. The setup is shown in Fig. 1. The volume of the cylindrical transparent Teflon enclosure was approximately $8 \mathrm{~L}$ and it was equipped with inlet and outlet ports and a thermistor (Philips KTY 80/110, Royal Philips Electronics, Amsterdam, Netherlands) covered with Teflon tubing inside the enclosure. The photosynthetically active photon flux density (PPFD) was measured just above the enclosure by quantum sensor (LI-190SZ, LI-COR Biosciences, Lincoln, USA).

The flow through the enclosure was kept at about 3$5 \mathrm{~L} \mathrm{~min}^{-1}$. Ozone was removed from the incoming air using manganese oxide $\left(\mathrm{MnO}_{2}\right)$-coated copper nets. The emission rates were measured using the online GC-MS. From the enclosure outlet port air was directed through the $6 \mathrm{~m}$ long fluorinated ethylene propylene (FEP) inlet line (i.d. $1 / 8$ in.) to 


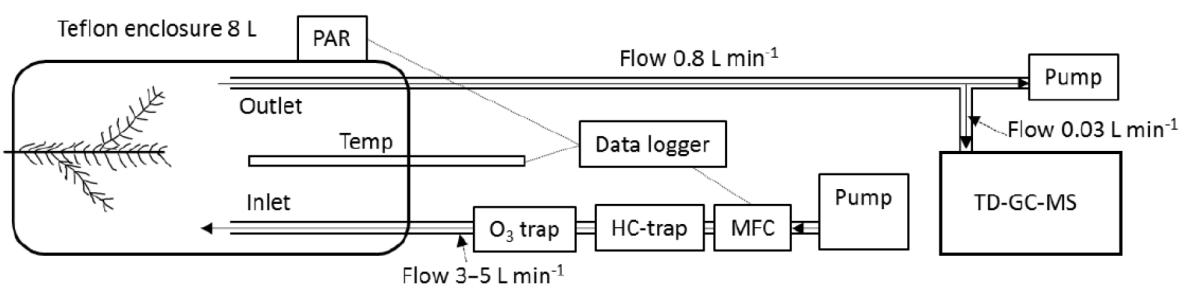

Figure 1. The emission measurement setup.

the GC-MS with a flow of $\sim 0.8 \mathrm{~L} \mathrm{~min}^{-1}$. Subsamples were taken from this main flow with a flow of $40-60 \mathrm{~mL} \mathrm{~min}^{-1} \mathrm{di}$ rectly into the cold trap of a thermal desorption unit (Perkin Elmer ATD-400) packed with Tenax TA in 2011 and Tenax TA/Carbopack-B in 2014 and 2015. The trap material was changed since isoprene was found not to be retained fully in the cold trap in 2011 . The trap was kept at $20^{\circ} \mathrm{C}$ during sampling to prevent water vapour present in the air from accumulating in the trap. The thermal desorption instrument was connected to a gas chromatograph (HP 5890) with DB-1 column $(60 \mathrm{~m}$, i.d. $0.25 \mathrm{~mm}$, f.t. $0.25 \mu \mathrm{m})$ and a mass selective detector (HP 5972). One 20 min sample was collected every other hour. The system was calibrated using liquid standards in methanol injected on Tenax TA-Carbopack B adsorbent tubes. The detection limit was below $1 \mathrm{pptv}$ for every MT and SQT.

The following compounds were included in the calibration solutions: 2-methyl-3-buten-2-ol (MBO) (Fluka), camphene (Aldrich), 3-carene (Aldrich), p-cymene (SigmaAldrich), 1,8-cineol (Aldrich), limonene (Fluka), linalool (Aldrich), myrcene (Aldrich), $\alpha$-pinene (Sigma-Aldrich), $\beta$-pinene (Fluka), terpinolene (Fluka), bornylacetate (Aldrich), longicyclene (Aldrich), isolongifolene (Aldrich), $\beta$-caryophyllene (Sigma), aromadendrene (Sigma-Aldrich), $\alpha$-humulene (Aldrich), $\beta$-farnesene (Chroma Dex). Isoprene was calibrated using gaseous standard from the National Physical Laboratory (NPL). We had no standard for sabinene and therefore it was quantified using the calibration curve of $\beta$-pinene, because both species elute close to each other and their mass spectra are similar. Therefore the results for sabinene are only semi-quantitative, but it enables the observations of diurnal and seasonal changes. Compared to offline adsorbent methods this in situ GC-MS had clearly lower background for carbonyl compounds and in 2015 we were able to measure also acetone/propanal and $\mathrm{C}_{4}-\mathrm{C}_{10}$ aldehyde emission rates. The aldehydes included in the calibration solutions were: butanal (Fluka), pentanal (Fluka), hexanal (Aldrich), heptanal (Aldrich), octanal (Aldrich), nonanal (Aldrich), and decanal (Fluka). Unfortunately, acetone co-eluted with propanal and the calibration was not linear due to high acetone background in adsorbent tubes used for calibrations.

\subsection{Calculation of emission rates}

The emission rate is determined as the mass of compound per needle dry weight and per time according to

$E=\frac{\left(C_{2}-C_{1}\right) F}{m}$.

Here $C_{2}$ is the concentration in the outgoing air, $C_{1}$ is the concentration in the incoming air, and $F$ is the flow rate into the enclosure. The dry weight of the biomass $(m)$ was determined by drying the needles and shoot from the enclosure at $75^{\circ} \mathrm{C}$ for $24 \mathrm{~h}$ after the last sampling date. We also measured needle leaf areas, and the specific leaf area (SLA) is $136 \mathrm{~m}^{2} \mathrm{~g}^{-1}$.

\subsection{Emission potentials}

A strong dependence of biogenic VOC emissions on temperature has been seen in all emission studies of isoprene, MTs, and SQTs (e.g. Kesselmeier and Staudt, 1999; Ciccioli et al., 1999; Hansen and Seufert 2003; Tarvainen et al., 2005; Hakola et al., 2006). The temperature-dependent pool emission rate is usually parameterized using a log-linear formulation:

$E(T)=E_{\mathrm{S}} \exp \left(\beta\left(T-T_{\mathrm{S}}\right)\right)$,

where $E(T)$ is the emission rate $\left(\mu \mathrm{gg}^{-1} \mathrm{~h}^{-1}\right)$ at leaf temperature $T$ and $\beta$ is the slope $\frac{\mathrm{d} \ln E}{\mathrm{~d} T}$ (Guenther et al., 1993). $E_{\mathrm{S}}$ is the emission rate at standard temperature $T_{\mathrm{S}}$ (usually set at $30^{\circ} \mathrm{C}$ ). The emission rate at standard temperature is also called the emission potential of the plant species, and while it is sometimes held to be a constant it may show variability related to, for example, season or the plant developmental stage (e.g. Hakola et al., 1998, 2001, 2003, 2006; Tarvainen et al., 2005; Aalto et al., 2014).

As well as the temperature-dependent nature of the biogenic emissions, light dependence was also discovered in early studies of plant emissions (see, e.g., the review of biogenic isoprene emission by Sanadze, 2004 and Ghirardo et al., 2010). The effect of light on emission potentials is based on the assumption that emissions follow a similar pattern of saturating light response to that which is observed for photosynthesis, and the formulation of the temperature effect is adopted from simulations of the temperature response of en- 
zymatic activity. The algorithm formulation is given, for example, in Guenther et al. (1993) and Guenther (1997).

In this work we have carried out nonlinear regression analysis with two fitted parameters, arriving at individual standard emission rates and slope values for the modelled MT, SQT and carbonyl compounds during each model period. The compounds analysed with the temperature-dependent pool emission rate were the most copiously emitted MTs and SQTs, other MTs, other SQTs, acetone, and sum of aldehydes. The light- and temperature-controlled instant emission rates were obtained for isoprene. An alternative modelling approach was tested using a hybrid emission algorithm, which has both the temperature-dependent pool emission and the light and temperature-controlled instant emission terms.

\subsection{Chemotype measurements}

In order to estimate the between-tree variability of the emissions, we conducted a study in 2014 , where we made qualitative monoterpene analysis from six different spruces (trees $3-$ 8) growing in the same area not farther than about $10 \mathrm{~m}$ from each other. All the trees were about $1 \mathrm{~m}$ high and naturally regenerated from local seeds. A branch was enclosed in a Teflon bag and after waiting for $5 \mathrm{~min}$ we collected a 5 min sample on a Tenax TA/Carbopack-B tube for analysis later in a laboratory using a Perkin-Elmer thermodesorption instrument (Turbomatrix 650) connected to a Perkin-Elmer gas chromatograph (Clarus 600) mass spectrometer (Clarus 600T) with DB-5 column. The samples were taken during one afternoon on 24 June 2014.

\subsection{Calculating the reactivity of the emissions}

We calculated the total reactivity of the emissions $\left(\mathrm{TCRE}_{x}\right)$ by combining the emission rates $\left(E_{i}\right)$ with reaction rate coefficients $\left(k_{i, x}\right)$ :

$\operatorname{TCRE}_{x}=\sum E_{i} k_{i, x}$.

This determines approximately the relative role of the compounds or compound classes in local $\mathrm{OH}$ and $\mathrm{O}_{3}$ chemistry. The reaction rate coefficients are listed in Table 1. When available, temperature-dependent rate coefficients have been used. When experimental data were not available, the reaction coefficients were estimated with the AopWin ${ }^{\mathrm{TM}}$ module of the $\mathrm{EPI}^{\mathrm{TM}}$ software suite (https://www.epa.gov/tsca-screening-tools/ epi-suitetm-estimation-program-interface, EPA, USA).

\section{Results and discussion}

\subsection{Weather patterns during the measurements}

According to the statistics of the Finnish Meteorological Institute, the weather conditions in Finland were close to nor- mal during the growing season in the years the measurements were carried out. The main features of the weather patterns are characterized here briefly to provide an average estimate of the conditions in the measurement years compared with the long-term average (the 30-year climatological normal period) conditions in Finland.

In 2011, the spring was early and warm. Thermal spring (mean daily temperature above $0^{\circ} \mathrm{C}$ ) started in the whole country during the first few days of April. The average temperatures in central Finland were $2-3^{\circ} \mathrm{C}$ higher than the normal long-term average temperatures. The precipitation in April was about $70 \%$ of the long-term average, and even a little less in central Finland.

The same pattern continued in May, with slightly higher temperatures than the normal long-term average. Towards the end of the month the weather turned more unstable, with more rains and cooler night temperatures. The average temperature in June was a little over $2{ }^{\circ} \mathrm{C}$ higher than the normal long-term average, and there were some intense thunderstorms.

In 2014, the weather conditions in May were quite typical, with the average temperatures close to the long-term average values in all parts of the country. The month started with temperatures cooler than the long-term average, and the cool period continued for about 3 weeks. After the cool period the weather became warmer with a southeastern air flow, and hot (over $25^{\circ} \mathrm{C}$ ) air temperatures were observed in southern and central parts of the country. Towards the end of May, cooler air spread over the country from the northeast, and the temperature drops could be high in eastern Finland. May was also characterized with precipitation, especially in eastern Finland. June started with a warm spell, but towards the end the weather was much cooler, with the average temperatures 1 to $2^{\circ} \mathrm{C}$ lower than the long-term average. The precipitation was regionally quite variable in June, the amount could be double the long-term average in some areas, while the amounts were only half of it in many places in central Finland. July was much warmer than long-term average temperature, especially in western Finland and in Lapland. July also had very little rain.

In 2015 , the June average temperatures were 1 to $2^{\circ} \mathrm{C}$ below the long-term averages, especially in the western parts of central Finland, and southern Lapland. There were also more rain showers than normally. In July the cold spell and rainy days continued, with average temperatures below the longterm averages, especially in the eastern parts of the country. Highest precipitation rates were measured in the southern and western coastal regions, and in the eastern parts of the country. In August the warmth returned after two cooler months, with average temperatures 1 to $2^{\circ} \mathrm{C}$ above the longterm average values. August also had very little rain, except for some parts in eastern Finland and in Lapland.

The observed mean temperature and precipitation amounts at the Juupajoki weather station in Hyytiälä during each mea- 
Table 1. $\mathrm{OH}$ and $\mathrm{O}_{3}$ reaction rate coefficients used in reactivity calculations.

\begin{tabular}{|c|c|c|c|c|}
\hline Species & $k_{\mathrm{OH}}\left(\mathrm{cm}^{3} \mathrm{~s}^{-1}\right)$ & Reference & $k_{\mathrm{O}_{3}}\left(\mathrm{~cm}^{3} \mathrm{~s}^{-1}\right)$ & Reference \\
\hline Isoprene & $2.7 \times 10^{-11} \cdot e^{390 / T}$ & Atkinson et al. $(2006)^{\mathrm{a}}$ & $1.03 \times 10^{-14} e^{-1995 / T}$ & Atkinson et al. (2006) ${ }^{\mathrm{a}}$ \\
\hline 2-Methyl-3-buten-2-ol & $6.3 \times 10^{-11}$ & Atkinson et al. (2006) ${ }^{\mathrm{a}}$ & $1.0 \times 10^{-17}$ & Atkinson et al. (2006) ${ }^{\mathrm{a}}$ \\
\hline$\alpha$-Pinene & $1.2 \times 10^{-11} \cdot e^{440 / T}$ & Atkinson et al. (2006) ${ }^{\mathrm{a}}$ & $8.05 \times 10^{-16} \cdot e^{-640 / T}$ & IUPAC $^{b}$ \\
\hline Camphene & $5.33 \times 10^{-11}$ & Atkinson et al. (1990a) & $6.8 \times 10^{-19}$ & IUPAC $^{b}$ \\
\hline Sabinene & $1.17 \times 10^{-10}$ & Atkinson et al. (1990a) & $8.2 \times 10^{-17}$ & IUPAC $^{\mathrm{b}}$ \\
\hline$\beta$-Pinene & $1.55 \times 10^{-11} \cdot e^{467 / T}$ & Atkinson and Arey (2003) & $1.35 \times 10^{-15} \cdot e^{-1270 / T}$ & IUPAC $^{b}$ \\
\hline Myrcene & $9.19 \times 10^{-12} \cdot e^{1071 / T}$ & Hites and Turner (2009) & $2.65 \times 10^{-15} \cdot e^{-520 / T}$ & IUPAC $^{\mathrm{b}}$ \\
\hline 3-Carene & $8.8 \times 10^{-11}$ & Atkinson and Arey (2003) & $4.8 \times 10^{-17}$ & IUPAC $^{\mathrm{b}}$ \\
\hline$p$-Cymene & $1.51 \times 10^{-11}$ & Corchnoy and Atkinson (1990) & $<5.0 \times 10^{-20}$ & Atkinson et al. (1990b) \\
\hline Limonene & $4.2 \times 10^{-11} \cdot e^{401 / T}$ & Gill and Hites (2002) & $2.8 \times 10^{-15} \cdot e^{-770 / T}$ & IUPAC $^{b}$ \\
\hline 1,8-Cineol & $1.11 \times 10^{-11}$ & Corchnoy and Atkinson (1990) & $<1.5 \times 10^{-19}$ & Atkinson et al. (1990b) \\
\hline Linalool & $1.59 \times 10^{-10}$ & Atkinson et al. (1995) & $\geq 3.15 \cdot 10^{-16}$ & $\begin{array}{l}\text { Grosjean and } \\
\text { Grosjean (1998) }\end{array}$ \\
\hline Terpinolene & $2.25 \times 10^{-10}$ & Corchnoy and Atkinson (1990) ${ }^{\mathrm{a}}$ & $1.6 \times 10^{-15}$ & IUPAC $^{\mathrm{b}}$ \\
\hline Bornylacetate & $1.39 \times 10^{-11}$ & Coeur et al. (1998) & - & \\
\hline Longicyclene & $9.35 \times 10^{-12}$ & AopWin ${ }^{\mathrm{TM}}$ v1.92 & - & \\
\hline Isolongifolene & $9.62 \times 10^{-11}$ & AopWin ${ }^{\mathrm{TM}}$ v1.92 & $1.0 \times 10^{-17}$ & IUPAC $^{\mathrm{b}}$ \\
\hline$\beta$-Caryophyllene & $2.0 \times 10^{-10}$ & Shu and Atkinson $(1995)^{\mathrm{a}}$ & $1.2 \times 10^{-14}$ & IUPAC $^{b}$ \\
\hline$\beta$-Farnesene & $1.71 \times 10^{-10}$ & Kourtchev et al. (2012) & $1.5 \times 10^{-12} \cdot e^{-2350 / T}$ & IUPAC $^{\mathrm{b}}$ \\
\hline$\alpha$-Humulene & $2.9 \times 10^{-10}$ & Shu and Atkinson $(1995)^{\mathrm{a}}$ & $1.2 \times 10^{-14}$ & IUPAC $^{\mathrm{b}}$ \\
\hline Alloaromadendrene & $6.25 \times 10^{-11}$ & AopWin ${ }^{\mathrm{TM}} \mathrm{v} 1.92$ & $1.20 \times 10^{-17}$ & AopWin ${ }^{\mathrm{TM}}$ v1.91 \\
\hline Zingiberene & $2.87 \times 10^{-10}$ & AopWin ${ }^{\mathrm{TM}}$ v1.92 & $1.43 \times 10^{-15}$ & AopWin $^{\mathrm{TM}} \mathrm{v} 1.91$ \\
\hline Acetone & $\begin{array}{l}8.8 \times 10^{-12} \cdot e^{-1320 / T} \\
+1.7 \times 10^{-14} \cdot e^{423 / T}\end{array}$ & Atkinson et al. (2006) ${ }^{\mathrm{a}}$ & - & \\
\hline Butanal & $6.0 \times 10^{-12} \cdot e^{410 / T}$ & Atkinson et al. (2006) ${ }^{\mathrm{a}}$ & - & \\
\hline Pentanal & $9.9 \times 10^{-12} \cdot e^{306 / T}$ & Thévenet et al. (2000) & - & \\
\hline Hexanal & $4.2 \times 10^{-12} \cdot e^{565 / T}$ & Jiménez et al. (2007) & - & \\
\hline Heptanal & $2.96 \times 10^{-11}$ & Albaladejo et al. (2002) & - & \\
\hline Octanal & $3.2 \times 10^{-11}$ & AopWin ${ }^{\text {TM }}$ v1.92 & - & \\
\hline Nonanal & $3.6 \times 10^{-11}$ & Bowman et al. (2003) & - & \\
\hline Decanal & $3.5 \times 10^{-11}$ & AopWin ${ }^{\mathrm{TM}} \mathrm{v} 1.92$ & - & \\
\hline
\end{tabular}

${ }^{a}$ IUPAC recommendation. ${ }^{b}$ IUPAC Task Group on Atmospheric Chemical Kinetic Data Evaluation (http://iupac.pole-ether.fr).

Table 2. Mean temperatures $\left({ }^{\circ} \mathrm{C}\right)$ and rain amounts $(\mathrm{mm})$ during each measurement month in Hyytiälä.

\begin{tabular}{lrr|rr|rr}
\hline & \multicolumn{2}{c|}{2011} & \multicolumn{2}{c|}{2014} & \multicolumn{2}{c}{2015} \\
\cline { 2 - 7 } & temp & rain & temp & rain & temp & rain \\
\hline April & 4.5 & 17.4 & & & & \\
May & 9.3 & 44.3 & 9.4 & 57.4 & & \\
June & 15.8 & 65.3 & 11.8 & 94.8 & 11.9 & 81.5 \\
July & & & 18.6 & 44.1 & 14.6 & 86.7 \\
August & & & & & 15.2 & 12.6
\end{tabular}

surement month in 2011, 2014, and 2015 are shown in Table 2 .

\subsection{Variability of the VOC emissions}

Seasonal mean emission rates of isoprene, 2-methyl-3-buten2-ol (MBO), MTs, and SQTs are presented in Table 3 and
Fig. 2. Typical diurnal variations of the most abundant compounds for each season are shown in Fig. 3. Since most of the emission rates of the measured compounds were higher in late summer than in early summer, we calculated the spring (April and May), early summer (June to mid-July) and late summer (late July and August) mean emissions separately. This describes that the emission rate changes better than monthly means.

Isoprene emission rates were low in spring and early summer, but increased in August. In spring emission rates were below detection limit most of the time and early and late summer means were $1.3 \pm 3.7$ and $6.0 \pm 12 \mathrm{ng}$ (dry weight $)^{-1} h^{-1}$, respectively. The highest daily maxima isoprene emissions were about 70-80 $\mathrm{ng} g(\mathrm{dw})^{-1} \mathrm{~h}^{-1}$, but usually they remained below $20 \mathrm{ng} \mathrm{g}(\mathrm{dw})^{-1} \mathrm{~h}^{-1}$. Our measured values (Table 3) match very well with the measurements by Bourtsoukidis et al. (2014b) who report season medians varying from $1.6 \mathrm{ng}$ (dry weight $)^{-1} \mathrm{~h}^{-1}$ in autumn to $3.7 \mathrm{ng} g(\mathrm{dw})^{-1} \mathrm{~h}^{-1}$ in spring. However, while the highest 

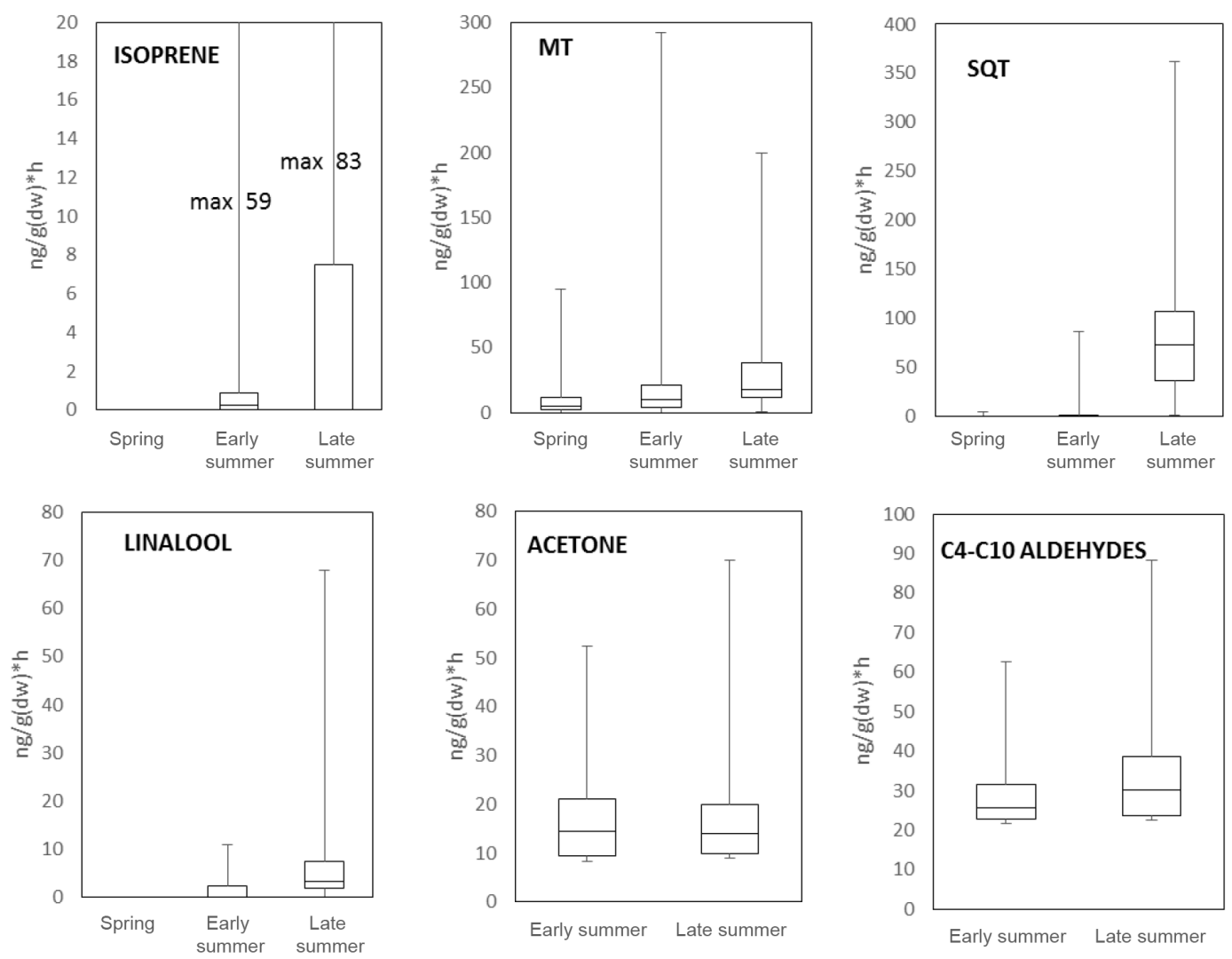

Figure 2. Season mean box and whisker plots of isoprene, MT, SQT, acetone, $\mathrm{C}_{4}-\mathrm{C}_{10}$ aldehydes (butanal, pentanal, hexanal, heptanal, octanal, nonanal, and decanal) and linalool. Boxes represent second and third quartiles and vertical lines in the boxes median values. Whiskers show the highest and the lowest observations.

emission rates were measured in late summer in the present study, Bourtsoukidis et al. (2014b) found highest emission rates in spring.

MT emission rates were below $50 \mathrm{ng} \mathrm{g}(\mathrm{dw})^{-1} \mathrm{~h}^{-1}$ most of the time in April and May, and still in the beginning of June for every measurement year, below $50 \mathrm{ng} g(\mathrm{dw})^{-1} \mathrm{~h}^{-1}$ most of the time. At the end of June the MT emission rates started to increase (about $30 \%$ ) to the level where they remained until the end of August, the daily maxima or their sum remaining below $300 \mathrm{ng}(\mathrm{dw})^{-1} \mathrm{~h}^{-1}$. In comparison with the study by Bourtsoukidis et al. (2014b), MT emission rates in Finland are four to ten times lower than those measured in Germany and their seasonal cycles are different. As with isoprene, they measured the highest MT emission rates during spring, whereas our highest emissions take place late summer. Median seasonal values reported by them are 203.1, 136.5, and $80.8 \mathrm{ng} \mathrm{g}(\mathrm{dw})^{-1} \mathrm{~h}^{-1}$ for spring, summer, and autumn, respectively. Our averages are 8,21 , and $28 \mathrm{ng} g(\mathrm{dw})^{-1} \mathrm{~h}^{-1}$ for spring, early summer, and late summer, respectively (Table 3 ).

A substantial change in the emission patterns took place at the end of July, when SQT emission rates increased up to 3-4 times higher than the MT emission rates at the same time (Table 3). Such a change in emissions was not observed in the study by Bourtsoukidis et al. (2014b). Instead of late summer increase, they again observed highest emissions during the spring (118.6 and $64.9 \mathrm{ng} \mathrm{g}(\mathrm{dw})^{-1} \mathrm{~h}^{-1}$ in spring and summer, respectively) after which emissions significantly declined. Moreover, they report that MTs dominated the Norway spruce emissions through the entire measuring period (April-November), SQT emission rates being equal to MT emission rates during spring, but only about half of MT emission rates during summer and about $20 \%$ during autumn. One potential explanation for such a different seasonality and emission strengths may lie in the differences between sitespecific factors such as soil moisture conditions, local climate (winter in Germany is much milder and the trees do not face as dramatic change as in Finland when winter turns to spring), stand age, or stress factors. The tree measured in Germany was much older (about 80 years). In a boreal forest, late summer normally is the warmest and most humid season favouring high emissions, as was also the case in our study periods. In contrast, in central Germany July was relatively cold and wet, and according to the authors, reduced emissions were therefore not surprising (Boutsourkidis et al., 2014b). 
Table 3. Seasonal mean emission rates of isoprene, 2-methylbutenol (MBO), MT, SQT, acetone, and $\mathrm{C}_{4}-\mathrm{C}_{10}$ carbonyls in ng $\mathrm{g}(\mathrm{dw})^{-1} \mathrm{~h}^{-1}$. "na" means that the compounds were not included in the analysis. Spring is April-May, early summer 1.6-15.7, and late summer 16.7-31.8. bdl: below detection limit. Values are averages and standard deviations for the three measurement years (2011, 2014, 2015). Other SQT: sum of all other SQTs in emissions. The number of the measurements each season is in parentheses.

\begin{tabular}{|c|c|c|c|c|c|c|}
\hline & \multicolumn{2}{|c|}{ Spring (337) } & \multicolumn{2}{|c|}{ Early summer (534) } & \multicolumn{2}{|c|}{ Late summer (159) } \\
\hline & average & SD & average & $\mathrm{SD}$ & average & SD \\
\hline Isoprene & & & 1.3 & 3.7 & 6.0 & 12 \\
\hline MBO & & & 2.1 & 4.2 & 2.4 & 3.8 \\
\hline Camphene & 1.1 & 1.8 & 2.9 & 4.4 & 3.8 & 4.1 \\
\hline 3-Carene & 0.3 & 0.7 & 1.1 & 1.7 & 0.9 & 0.6 \\
\hline$p$-Cymene & 0.3 & 0.6 & 0.9 & 1.8 & 0.5 & 0.5 \\
\hline Limonene & 2.7 & 3.4 & 6.1 & 12.2 & 7.7 & 9.5 \\
\hline Myrcene & 0.2 & 0.4 & 1.7 & 3.7 & 3.9 & 5.1 \\
\hline$\alpha$-Pinene & 2.1 & 3.4 & 5.8 & 11.1 & 9.6 & 11 \\
\hline$\beta$-Pinene & 1.0 & 2.2 & 1.8 & 6.2 & 0.9 & 1.1 \\
\hline Sabinene & 0 & 0.1 & 0.5 & 1.5 & 0.9 & 1.6 \\
\hline Terpinolene & 0 & 0.2 & 0.1 & 0.4 & 0.3 & 0.9 \\
\hline Bornylacetate & 0 & 0.2 & 0.5 & 2.0 & 1.1 & 2.1 \\
\hline 1,8-Cineol & 0.7 & 0.7 & 2.1 & 3.9 & 1.8 & 2.2 \\
\hline Linalool & na & & 1.4 & 2.2 & 7.9 & 12 \\
\hline$\beta$-Caryophyllene & 0 & 0 & 0.4 & 2.1 & 7.2 & 5.9 \\
\hline$\beta$-Farnesene & 0 & 0 & 1.1 & 4.3 & 42 & 29 \\
\hline Other SQT & 0.1 & 0.4 & 1.4 & 4.7 & 35 & 30 \\
\hline Acetone & na & & 17 & 11 & 17 & 9.0 \\
\hline Butanal & na & & 2.0 & 0.7 & 0.3 & 0.3 \\
\hline Pentanal & na & & 4.1 & 1.1 & 2.4 & 0.9 \\
\hline Hexanal & na & & 5.0 & 3.0 & 4.9 & 2.1 \\
\hline Heptanal & na & & 5.2 & 1.2 & 7.5 & 2.4 \\
\hline Octanal & na & & 0.3 & 0.1 & 0.4 & 1.1 \\
\hline Nonanal & na & & 6.3 & 2.3 & 9.9 & 4.5 \\
\hline Decanal & na & & 5.6 & 2.3 & 7.4 & 3.8 \\
\hline
\end{tabular}

Another interesting feature can be seen in the specified emission rates of different compounds. In the present study the main SQT in spruce emissions was $\beta$-farnesene. About $50 \%$ of the SQT emission consisted of $\beta$-farnesene and its maximum emission rate $\left(155 \mathrm{ng} g(\mathrm{dw})^{-1} \mathrm{~h}^{-1}\right)$ was measured on the afternoon of 31 July 2015 . Two other identified SQTs were $\beta$-caryophyllene and $\alpha$-humulene. There were two more SQTs, which also contributed significantly to the total SQT emission rates, but since no calibration standards were available for these, their quantification is only tentative. Linalool emissions increased simultaneously with SQT emissions (Fig. 2) reaching maximum concentrations during late summer in August, in the same way as was previously observed in the measurements of Scots pine emissions in the same forest in southern Finland (Hakola et al., 2006), where emissions were found to increase late summer concomitant with the maximum concentration of the airborne pathogen spores, and Hakola et al. (2006) suggested a potential defensive role of the conifer linalool and SQT emissions. Several other reports point to similar correlations between SQT (in particular $\beta$-farnesene) and oxygenated MTs such as linalool emissions and biotic stresses in controlled experiments. For example, increases in farnesene, methyl salicylate (MeSA), and linalool emissions were reported to be an induced response by Norway spruce seedlings to feeding damage by mite species (Kännaste et al., 2009), indicating that their biosynthesis might prevent the trees from being damaged. Interestingly, the release of $\beta$-farnesene seemed to be mite specific and attractive to pine weevils, whereas linalool and MeSA were deterrents. Blande et al. (2009) discovered pine weevil feeding to clearly induce the emission of MTs and SQTs, particularly linalool and (E) $\beta$-farnesene, from branch tips of Norway spruce seedlings, Also, in a licentiate thesis of Petterson (2007) linalool and $\beta$-farnesene were shown to be emitted due to stress. The emissions from Norway spruce increased significantly after trees were treated with methyl jasmonate (MeJA). Martin et al. (2003) discovered that MeJA triggered increases in the rate of linalool emission more than 100 -fold and that of SQTs more than 30-fold. Emissions followed a pronounced diurnal rhythm with the maximum amount released during the light period, suggesting that they are induced de novo after treatment. Our study shows that such major changes in emission patterns can also occur in trees in field conditions, and without any clear visible in- 

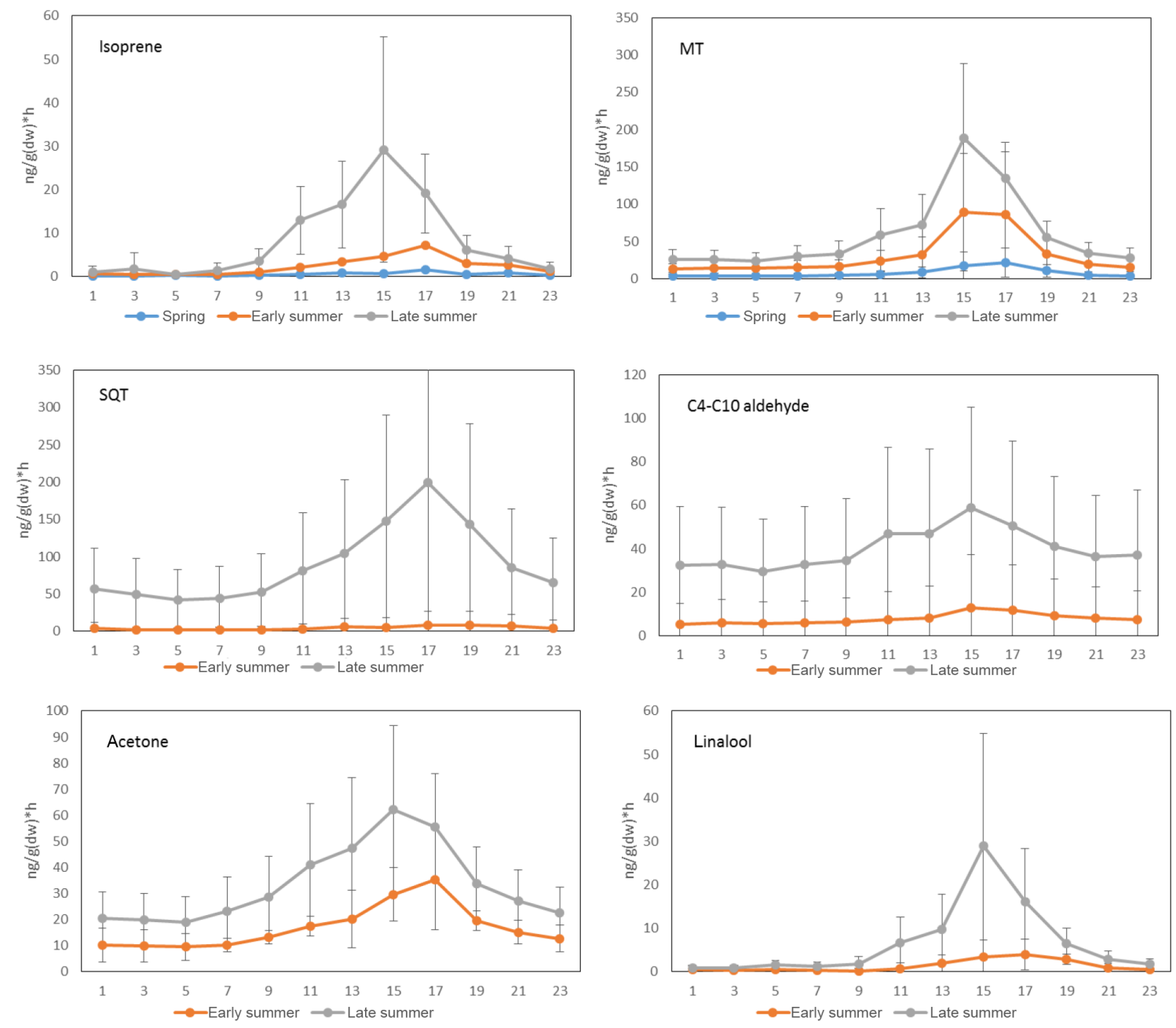

Figure 3. Mean diurnal variations of different compound groups in each season. Spring refers to April and May; early summer, June-midJuly; late summer, mid-July-August. Aldehydes are the sum of all $\mathrm{C}_{4}-\mathrm{C}_{10}$ aldehydes (butanal, pentanal, hexanal, heptanal, octanal, nonanal, and decanal).

festations or feeding, indicating that they probably are systemic defence mechanisms rather than direct ones (Eyles et al., 2010).

In 2015 we measured also acetone/propanal and $\mathrm{C}_{4}-\mathrm{C}_{10}$ aldehyde emission rates. The total amount of these measured carbonyl compounds was comparable to the amount of MTs (Table 3) although with our method it was not possible to measure emissions of the most volatile aldehydes, formaldehyde and acetaldehyde, which are also emitted from trees in significant quantities (Cojocariu et al., 2004; Koppmann and Wildt, 2007; Bourtsoukidis et al., 2014b). In summer 2015 the carbonyl compounds consisted mainly of acetone $(30 \%)$, and the shares for the other compounds were as follows: nonanal $(21 \%)$, decanal $(17 \%)$, heptanal (14\%), hexanal $(10 \%)$, and pentanal $(5 \%)$. The shares of butanal and octanal were less than $2 \%$ each. The seasonal mean values are shown in Table 3. Aldehydes with shorter carbon backbones (butanal, pentanal, hexanal) have higher emissions in early summer like most MTs, while aldehydes with longer carbon backbones (heptanal, octanal, nonanal, decanal) have higher emissions in late summer similarly to SQTs.

Diurnal variability of the emission rates of MT and SQT, acetone/propanal and larger aldehydes are shown in Fig. 2. They all show similar temperature-dependent variability with maxima during the afternoon and minima in the night. The SQT daily peak emissions were measured $2 \mathrm{~h}$ later than MT and aldehyde peaks.

\subsection{Tree-to-tree variability in emission pattern}

When following the emission seasonality, we discovered that the MT emission patterns were somewhat different between the two trees measured. The tree measured in 2011 (tree 1) emitted mainly $\alpha$-pinene in May, whereas the tree measured in 2014 and 2015 (tree 2) emitted mainly limonene in May (Table 4). As summer proceeded the contribution 
Table 4. Average monthly abundances (\%) of emitted MTs. T1 (tree 1) includes 2011 and T2 2014 and 2015 measurements. The number of the measurements each month is in parentheses.

\begin{tabular}{|c|c|c|c|c|c|c|c|c|c|}
\hline & $\alpha$-Pinene & Camphene & Sabinene & $\beta$-Pinene & Myrcene & $\Delta^{3}$-Carene & $p$-Cymene & Limonene & Terpinolene \\
\hline April, T1 (160) & 34 & 19 & 0 & 18 & 1 & 5 & 6 & 18 & 0 \\
\hline May, T1 (48) & 59 & 9 & 1 & 7 & 1 & 1 & 9 & 10 & 3 \\
\hline June, T1 (34) & 7 & 25 & 16 & 0 & 34 & 3 & 9 & 4 & 0 \\
\hline May, T2 (129) & 16 & 11 & 0 & 10 & 5 & 5 & 2 & 51 & 0 \\
\hline June, T2 (396) & 27 & 15 & 0 & 15 & 5 & 5 & 4 & 29 & 0 \\
\hline July, T2 (128) & 32 & 15 & 2 & 5 & 7 & 5 & 2 & 27 & 1 \\
\hline Aug, T2 (134) & 34 & 11 & 3 & 3 & 15 & 3 & 1 & 29 & 1 \\
\hline
\end{tabular}

of limonene emission decreased in both trees and the share of $\alpha$-pinene increased in tree 2 . The species-specific Norway spruce emissions have been measured earlier at least by Hakola et al. (2003) and Bourtsoukidis et al. (2014a). The measurements by Hakola et al. (2003) covered all seasons, but only a few daytime samples for each season, whereas the measurements by Bourtsoukidis et al. (2014a) covered 3 weeks in September-October in an Estonian forest. The main MTs detected in the Estonian forest were $\alpha$-pinene $(59 \%)$ and 3 -carene $(26 \%)$, but also camphene, limonene, $\beta$-pinene and $\beta$-phellandrene were detected. In the study by Hakola et al. (2003) the MT emission composed mainly of $\alpha$-pinene, $\beta$-pinene, camphene, and limonene, but only very small amounts of 3-carene were observed, similarly to the present study. This raises the question of whether spruces would have different chemotypes in a similar way as Scots pine has (Bäck et al., 2012).

In order to find out how much variability there was between the trees in monoterpene emission pattern, we conducted a study in June in 2014, where we made qualitative analysis from six different spruces growing in the same area (labelled as trees 3-8). The results for MT emissions are shown in Fig. 4. SQT emissions were not significant at that time (about $1 \mathrm{ng} g(\mathrm{dw})^{-1} \mathrm{~h}^{-1}$ ). As expected, the MT emission pattern of the trees was quite different; terpinolene was one of the main MT in the emission of four trees whereas tree 3 emitted only $3 \%$ terpinolene. Also limonene and camphene contributions were varying from a few percent to about a third of the total MT emission. All the measured trees emitted rather similar proportions of $\alpha$ - and $\beta$-pinene. The shares of myrcene, $\beta$-pinene, and 3-carene were low in every tree. Since different MTs react at different rates in the atmosphere (Table 1), the species-specific measurements are necessary when evaluating MTs influence on atmospheric chemistry. Currently, air chemistry models very often use only single branch measurements and this can lead to biased results when predicting product and new particle formation. This study and the study of Scots pine emissions by Bäck et al. (2012) show that species-specific measurements are necessary, but also that flux measurements are more representative than branch-scale emission measurements, and that av-

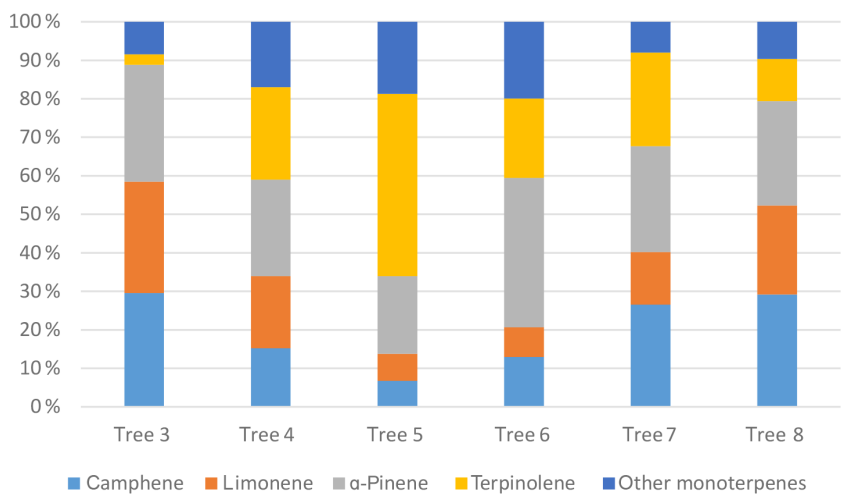

Figure 4. Relative abundances of emitted monoterpenes in six different spruce individuals on 24 June 2014.

eraging over larger spatial scale may be better suited for air chemistry models.

\subsection{Standard emission potentials}

The standard emission potentials were obtained by fitting the measured emission rates to the temperature-dependent pool emission algorithm (Eq. 2) and the light- and temperaturedependent algorithm described in Sect. 2.3. For the temperature dependent algorithm, the nonlinear regression was carried out with two fitted parameters, yielding both the emission potentials and individual $\beta$ coefficients for each compound group. With the light- and temperature-dependent algorithm, only emission potentials were obtained. The compounds' emissions fitted using the temperature-dependent pool emission algorithm were the ones of the most abundant MT and SQT, and the carbonyls for each season, while the analysis with the light- and temperature-dependent emission algorithm was carried out for isoprene emissions. In the analysis, obvious outliers and other suspicious data were not included. The excluded values typically were the first values obtained right after starting a measurement period, which might still show the effects of handling the sample branch. The isoprene emissions obtained in 2011 were not taken into account in the analysis as they were not properly collected on the cold trap. This was fixed in 2014 and 2015 by changing 
Table 5. Standard $\left(30^{\circ} \mathrm{C}\right) \mathrm{MT}$, SQT, acetone, and $\mathrm{C}_{4}-\mathrm{C}_{10}$ aldehyde emission potentials obtained in 2011 , 2014, and 2015 . For isoprene the standard $\left(1000 \mu \mathrm{mol}\right.$ photons $\left.\mathrm{m}^{-2} \mathrm{~s}^{-1}, 30^{\circ} \mathrm{C}\right)$ emission potentials are from the 2015 campaign. The standard emission potential $E_{\mathrm{S}}$ and the $\beta$ coefficient are given with the standard error of the estimate (SE, in parentheses). $R$ squared and the number of measurements ( $N$, in parentheses). The fits were made for the spring (April-May), early summer (June-mid-July) and late summer (late July-August) periods.

\begin{tabular}{|c|c|c|c|}
\hline Spring & Es (SE) ng g(dw) ${ }^{-1} h^{-1}$ & $\beta \mathrm{K}^{-1}(\mathrm{SE})$ & $R^{2}(N)$ \\
\hline$\alpha$-Pinene & $11.6(0.7)$ & $0.097(0.006)$ & $0.423(331)$ \\
\hline Camphene & $2.5(0.4)$ & $0.045(0.009)$ & $0.071(323)$ \\
\hline$\beta$-Pinene & $1.9(0.2)$ & $0.044(0.007)$ & $0.119(324)$ \\
\hline Myrcene & $0.6(0.1)$ & $0.010(0.011)$ & $0.007(157)$ \\
\hline Limonene & $5.0(0.8)$ & $0.032(0.008)$ & $0.049(321)$ \\
\hline Other MT & $2.9(0.2)$ & $0.085(0.005)$ & $0.433(329)$ \\
\hline$\beta$-Caryophyllene & $0.2(0.1)$ & $0.018(0.059)$ & $0.026(6)$ \\
\hline$\beta$-Farnesene & - & - & $-(0)$ \\
\hline Other SQT & $0.7(0.3)$ & $0.046(0.029)$ & $0.029(72)$ \\
\hline \multicolumn{4}{|l|}{ Early summer } \\
\hline$\alpha$-Pinene & $14.1(1.0)$ & $0.058(0.006)$ & $0.145(489)$ \\
\hline Camphene & $7.0(0.3)$ & $0.060(0.004)$ & $0.230(492)$ \\
\hline$\beta$-Pinene & $5.2(0.6)$ & $0.062(0.010)$ & $0.076(426)$ \\
\hline Myrcene & $5.8(0.3)$ & $0.078(0.005)$ & $0.326(356)$ \\
\hline Limonene & $16.7(0.9)$ & $0.069(0.005)$ & $0.239(497)$ \\
\hline Other MT & $7.0(0.3)$ & $0.074(0.004)$ & 0.385 (499) \\
\hline$\beta$-Caryophyllene & $4.8(1.3)$ & $0.018(0.019)$ & $0.023(54)$ \\
\hline$\beta$-Farnesene & $6.9(1.8)$ & $0.012(0.018)$ & $0.007(90)$ \\
\hline Other SQT & $6.2(0.7)$ & $0.055(0.010)$ & $0.087(238)$ \\
\hline Acetone & $50.8(7.2)$ & $0.066(0.010)$ & $0.362(71)$ \\
\hline Aldehydes & $59.1(4.4)$ & $0.043(0.005)$ & $0.503(71)$ \\
\hline \multicolumn{4}{|l|}{ Late summer } \\
\hline Isoprene & $56.5(4.2)$ & & $0.473(70)$ \\
\hline$\alpha$-Pinene & $39.3(4.1)$ & $0.153(0.017)$ & $0.359(163)$ \\
\hline Camphene & $7.7(1.2)$ & $0.064(0.016)$ & $0.094(161)$ \\
\hline$\beta$-Pinene & $2.5(0.3)$ & $0.075(0.015)$ & $0.160(120)$ \\
\hline Myrcene & $21.1(2.0)$ & $0.191(0.019)$ & $0.476(154)$ \\
\hline Limonene & $32.3(3.6)$ & $0.155(0.018)$ & $0.336(163)$ \\
\hline Other MT & $9.9(1.1)$ & $0.133(0.016)$ & $0.298(153)$ \\
\hline$\beta$-Caryophyllene & $11.0(1.2)$ & $0.020(0.010)$ & $0.032(129)$ \\
\hline$\beta$-Farnesene & $76.9(7.5)$ & $0.060(0.010)$ & $0.183(162)$ \\
\hline Other SQT & $67.3(8.2)$ & $0.059(0.013)$ & $0.132(157)$ \\
\hline Acetone & $31.8(2.2)$ & $0.061(0.007)$ & $0.313(163)$ \\
\hline Aldehydes & $36.8(3.0)$ & $0.008(0.007)$ & $0.009(163)$ \\
\hline
\end{tabular}

the adsorbent material. An approach with a hybrid algorithm, where the emission rate is described as a function of two source terms, de novo synthesis emissions and pool emissions, was also tested. However, the results were not conclusive.

The standard emission potentials of isoprene, the selected MT and SQT, acetone, and $\mathrm{C}_{4}-\mathrm{C}_{6}$ aldehyde sums are presented in Table 5. Emission potentials are given as spring, early summer, and late summer values. The coefficient of determination $\left(R^{2}\right)$ is also given, even though it is an inadequate measure for the goodness of fit in nonlinear models (e.g. Spiess and Neumeyer, 2010). A more reliable parame- ter for estimating the goodness of fit is the standard error of the estimate, which is also given.

The summertime emission potentials of MT and SQT reflect the typical behaviour of the temperature variability in summer, with low emissions in spring and high emissions in the higher temperatures of late summer. The variability of the emission potential during the growing season and between the individual compounds is large. In late summer limonene and $\alpha$-pinene had the highest MT emission potentials. SQT exhibit a similar behaviour as monoterpene emission potentials with very low springtime and early summer emission potentials while the late sum- 
mer emission potential is high. In a review by Kesselmeier and Staudt (1999) the reported standard emission potentials $\left(30^{\circ} \mathrm{C}, 1000 \mu \mathrm{mol} \mathrm{m}{ }^{-2} \mathrm{~s}^{-1}\right)$ of Norway spruces for monoterpenes vary from 0.2 to $7.8 \mu \mathrm{gg}$ (dry weight $)^{-1} \mathrm{~h}^{-1}$ and in a study by Bourtsoukidis et al. (2014b) mean emission potential of Norway spruce was $0.89 \mu \mathrm{gg}(\text { dry weight })^{-1} \mathrm{~h}^{-1}$ for all data (spring, summer, fall). Our standardized MT emission potentials are lower than earlier reported values, being $0.1 \mu \mathrm{gg}(\text { dry weight })^{-1} \mathrm{~h}^{-1}$ during late summer, when they were at their highest.

This is the first time we have applied fitting the traditional temperature-based emission potential algorithms to measured carbonyl emissions, and based on the spruce emission results, the approach appears to be applicable also on these compounds. The best fit was obtained with the temperaturedependent algorithm. The temporal variability of the emission potential was similar to MT- and SQTs. Unfortunately, acetone/propanal and $\mathrm{C}_{4}-\mathrm{C}_{10}$ aldehyde measurements were only carried out during the last measurement campaign, but the emission pattern possibly indicates a midsummer maximum, because emissions were clearly identified in June, and already decreasing in late July-August. The isoprene emissions, fitted with the light and temperature emission algorithm, also reflect the light/temperature pattern of summer, with low emissions in spring and high emissions in late summer.

In late summer when isoprene emissions were a bit higher the emission model fits the data better and the emission potential for isoprene was $56.5 \mathrm{ng} \mathrm{g}(\text { dry weight })^{-1} \mathrm{~h}^{-1}$. In a review by Kesselmeier and Staudt (1999) the reported standard emission potentials $\left(30^{\circ} \mathrm{C}, 1000 \mu \mathrm{mol} \mathrm{m} \mathrm{m}^{-2} \mathrm{~s}^{-1}\right)$ of isoprene vary from 0.34 to $1.8 \mu \mathrm{gg}$ (dry weight $)^{-1} \mathrm{~h}^{-1}$. Our standardized late summer mean $\left(56.5 \mathrm{ng} \mathrm{g}(\text { dry weight })^{-1} \mathrm{~h}^{-1}\right)$ is much lower than these earlier reported values.

\subsection{Relative reactivity of emissions}

In summer in ambient air at this site most of the known $\mathrm{OH}$ reactivity (which is $\sim 50 \%$ of the total measured $\mathrm{OH}$ reactivity) is coming from the VOCs (Sinha et al., 2010; Nölcher et al., 2012). Other trace gases $\left(\mathrm{NO}_{x}, \mathrm{CO}, \mathrm{O}_{3}, \mathrm{CH}_{4}\right)$ have a lower contribution. Of these VOCs, aromatic hydrocarbons have only minor contribution compared to the terpenoids (Hakola et al., 2012). In these ambient air studies contribution of SQTs has been much lower than MTs, but those results are misleading, since lifetimes of most SQTs are so short that they cannot be detected in ambient air and estimation of their contribution to the local reactivity is possible only directly from the emissions. Here we studied the relative role of different BVOCs to the reactivity of Norway spruce emissions.

The relative contribution from each class of compounds to the total calculated $\mathrm{OH}$ and $\mathrm{O}_{3}$ reactivity of the emissions TCRE $_{\mathrm{OH}}$ and $\mathrm{TCRE}_{\mathrm{O}_{3}}$, respectively, is depicted in Fig. 5. Nitrate radicals are likely to contribute also significantly to
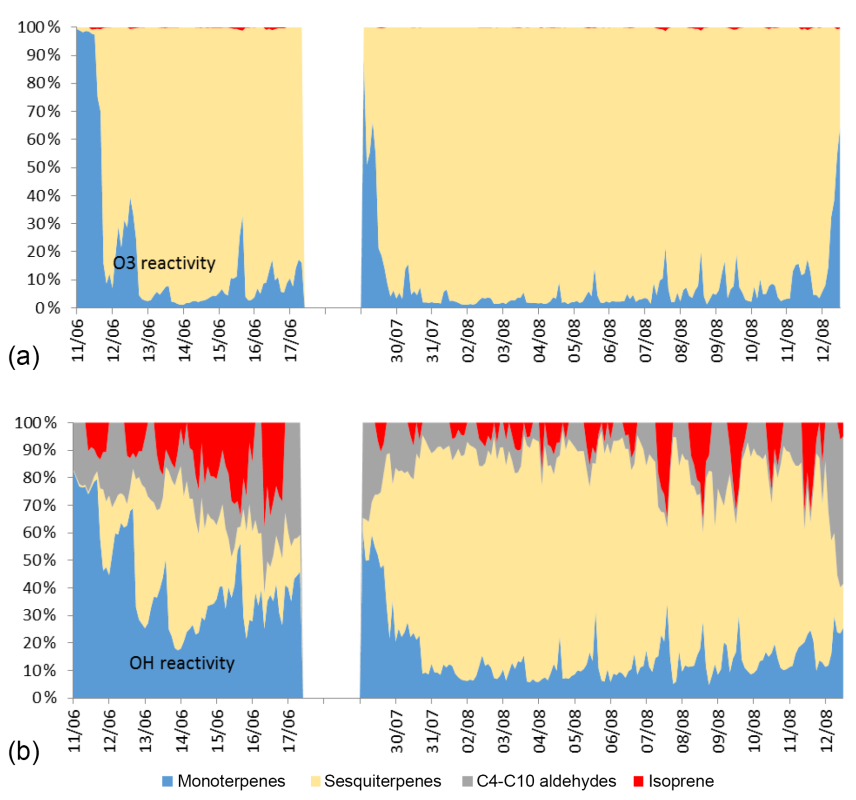

Figure 5. Relative $\mathrm{O}_{3}$ and $\mathrm{OH}$ reactivity of emissions for two periods in early and late summer 2015. The compounds and reaction coefficients used for reactivity calculations are presented in Table 1.

the reactivity, but since the reaction rate coefficients were not available for the essential compounds like $\beta$-farnesene, the nitrate radical reactivity is not shown. SQT are very reactive towards ozone and they clearly dominate the ozone reactivity. Isoprene contribution is insignificant all the time towards ozone reactivity, but it contributes $20-30 \%$ of $\mathrm{OH}$ reactivity, although the emission rates are quite low. SQT dominate also $\mathrm{OH}$ reactivity during late summer due to their high emission rates, but early summer MT contribution is equally important. Contribution of acetone to the TCRE $\mathrm{OH}$ was very small $(\sim 0.05 \%$ of total reactivity), but reactivity of $\mathrm{C}_{4}-\mathrm{C}_{10}$ aldehydes was significant, averagely $15 \%$ and sometimes over $50 \%$ of the TCRE $\mathrm{OH}_{\mathrm{H}}$. Of the aldehydes decanal, nonanal, and heptanal had the highest contributions. It is also possible to measure total $\mathrm{OH}$ reactivity directly and experimental total $\mathrm{OH}$ reactivity measurements by Nölscher et al. (2013) showed that the contribution of SQTs in Norway spruce emissions in Hyytiälä was very small $(\sim 1 \%)$. This is in contradiction to our measurements, where we found a very high share of SQTs ( $75 \%$ in late summer). Nölscher et al. (2013) also found a very high fraction of missing reactivity $(>80 \%)$ especially in late summer. Their measurements covered spring, summer, and autumn. Emissions of $\mathrm{C}_{4}-\mathrm{C}_{10}$ aldehydes, which were not studied by Nölscher et al. (2013), could explain part of the missing reactivity. 


\section{Conclusions}

Norway spruce VOC emissions were measured in campaigns in 2011, 2014 and 2015. Measurements covered altogether 14 spring and summer weeks. The measured compounds included isoprene, MT, and SQT and in 2015 also acetone and $\mathrm{C}_{4}-\mathrm{C}_{10}$ aldehydes. MT and SQT emission rates were low during spring and early summer. MT emission rates increased to their maximum at the end of June and declined a little in August. A significant change in SQT emissions took place at the end of July, when SQT emissions increased substantially. The seasonality is different from that observed earlier in Germany (Bourtsoukidis et al., 2014b). There Norway spruce emissions (isoprene, MT, SQT) were highest in spring and declined thereafter. The difference in seasonality can be due to different ages of the measured trees (10-15 years in the current study, 80 years in Bourtsoukidis et al., 2014b), different climate, or different stress factors. These same factors can also cause the lower emission rates measured now in comparison with other studies. The effect of age to the emission potentials should be studied.

In August SQT were the most abundant group in the emission, $\beta$-farnesene being the most dominant compound. SQT emissions increased simultaneously with linalool emissions and these emissions were suggested to be initiated due to stress effects. To our knowledge this is the first time when $\beta$-farnesene and linalool emissions have been shown to increase simultaneously in natural conditions, although they have been shown to increase in the emissions together due to stress effects. Of the measured compounds, SQTs had highest impact on local $\mathrm{O}_{3}$ and $\mathrm{OH}$ chemistry. This clearly shows the importance of considering also SQTs in atmospheric studies in boreal environment.

Acetone and $\mathrm{C}_{4}-\mathrm{C}_{10}$ aldehyde emissions were highest in July, when they were approximately at the same level as MT emissions. $\mathrm{C}_{4}-\mathrm{C}_{10}$ aldehydes contributed as much as MT to the $\mathrm{OH}$ reactivity during late summer, but early summer only about half of the MT share in early summer. This demonstrates that also emissions of other BVOCs than the traditionally measured terpenoids are important and should be included in atmospheric studies.

The MT emission pattern varies a lot from tree to tree. During one afternoon in June we measured the emission patterns of six different trees growing near each other and especially the amounts of terpinolene, camphene, and limonene were varying. Due to inconsistent emission patterns, speciesspecific emission fluxes at canopy level should be conducted in addition to the leaf level measurements for more representative measurements. However, only leaf-level measurements produce reliable SQT data.

Data availability. The data are available from the authors upon request.
Competing interests. The authors declare that they have no conflict of interest.

Acknowledgements. The financial support by the Academy of Finland Centre of Excellence programme (project no. 272041) and Academy Research Fellow programme (project no. 275608) are gratefully acknowledged. The authors thank Juho Aalto for determining the specific leaf area of the needles.

Edited by: A. Ding

Reviewed by: two anonymous referees

\section{References}

Aalto, J., Kolari, P., Hari, P., Kerminen, V.-M., Schiestl-Aalto, P., Aaltonen, H., Levula, J., Siivola, E., Kulmala, M., and Bäck, $\mathrm{J}$.: New foliage growth is a significant, unaccounted source for volatiles in boreal evergreen forests, Biogeosciences, 11, 13311344, doi:10.5194/bg-11-1331-2014, 2014.

Albaladejo, J., Ballesteros, B., Jiménez, E., Martín, P., and Martínez, E.: A PLP-LIF kinetic study of the atmospheric reactivity of a series of $\mathrm{C} 4-\mathrm{C} 7$ saturated and unsaturated aliphatic aldehydes with OH, Atmos. Environ., 36, 3231-3239, 2002.

Atkinson, R., Aschmann, S. M., and Arey, J.: Rate constants for the gas-phase reactions of $\mathrm{OH}$ and $\mathrm{NO}_{3}$ radicals and $\mathrm{O}_{3}$ with sabinene and camphene at $296 \pm 2 \mathrm{~K}$, Atmos. Environ., 24, 2647-2654, doi:10.1016/0960-1686(90)90144-C, 1990a.

Atkinson, R., Hasegawa, D., and Aschmann, S. M.: Rate constants for the gas-phase reactions of $\mathrm{O}_{3}$ with a series of monoterpenes and related compounds at $296 \pm 2 \mathrm{~K}$, Int. J. Chem. Kinet., 22, 871-887, doi:10.1002/kin.550220807, 1990b.

Atkinson, R., Arey, J., Aschmann, S. M., Corchnoy, S. B., and Shu, Y.: Rate constants for the gas-phase reactions of cis-3-Hexen-1ol, cis-3-Hexenylacetate, trans-2-Hexenal, and Linalool with $\mathrm{OH}$ and $\mathrm{NO}_{3}$ radicals and $\mathrm{O}_{3}$ at $296 \pm 2 \mathrm{~K}$, and $\mathrm{OH}$ radical formation yields from the $\mathrm{O}_{3}$ reactions, Int. J. Chem. Kinet., 27, 941-955, doi:10.1002/kin.550271002, 1995.

Atkinson, R. and Arey, J.: Atmospheric Degradation of Volatile Organic Compounds, Chem. Rev., 103, 4605-4638, doi:10.1021/cr0206420, 2003.

Atkinson, R., Baulch, D. L., Cox, R. A., Crowley, J. N., Hampson, R. F., Hynes, R. G., Jenkin, M. E., Rossi, M. J., Troe, J., and IUPAC Subcommittee: Evaluated kinetic and photochemical data for atmospheric chemistry: Volume II - gas phase reactions of organic species, Atmos. Chem. Phys., 6, 3625-4055, doi:10.5194/acp-6-3625-2006, 2006.

Bäck, J., Aalto, J., Henriksson, M., Hakola, H., He, Q., and Boy, M.: Chemodiversity of a Scots pine stand and implications for terpene air concentrations, Biogeosciences, 9, 689-702, doi:10.5194/bg-9-689-2012, 2012.

Blande, J. D., Turunen, K., and Holopainen, J. K.: Pine weevil feeding on Norway spruce bark has a stronger impact on needle VOC emissions than enhanced ultraviolet-B radiation, Environ. Pollut., 157, 174-180, 2009.

Bourtsoukidis, E., Bonn, B., Dittmann, A., Hakola, H., Hellén, H., and Jacobi, S.: Ozone stress as a driving force of sesquiter- 
pene emissions: a suggested parameterisation, Biogeosciences, 9, 4337-4352, doi:10.5194/bg-9-4337-2012, 2012.

Bourtsoukidis, E., Bonn, B., and Noe, S.: On-line field measurements of BVOC emissions from Norway spruce (Picea abies) at the hemiboreal SMEAR-Estonia site under autumn conditions, Boreal Environ. Res., 19, 153-167, 2014a.

Bourtsoukidis, E., Williams, J., Kesselmeier, J., Jacobi, S., and Bonn, B.: From emissions to ambient mixing ratios: online seasonal field measurements of volatile organic compounds over a Norway spruce-dominated forest in central Germany, Atmos. Chem. Phys., 14, 6495-6510, doi:10.5194/acp-14-6495-2014, 2014b.

Bourtsoukidis, E., Kawaletz, H., Radacki, D., Schutz, S., Hakola, H., Hellén, H., Noe, S., Molder, I., Ammer, C., and Bonn, B.: Impact of flooding and drought conditions on the emission of volatile organic compounds of Quercus robur and Prunus serotina, Trees, 28, 193-204, 2014c.

Bowman, J. H., Barket Jr., D. J., and Shepson, P. B.: Atmospheric Chemistry of Nonanal, Envir. Sci. Tech. Lib., 37, 2218-2225, doi:10.1021/es026220p, 2003.

Chameides, W. L., Fehsenfeld, F., Rodgers, M. O., Cardelino, C., Martinez, J., Parrish, D., Lonneman, W., Lawson, D. R., Rasmussen, R. A., Zimmerman, P., Greenberg, J., Middleton, P., and Wang, T.: Ozone precursor relationships in the ambient atmosphere, J. Geophys. Res., 97, 6037-6055, 1992.

Ciccioli, P., Brancaleoni, E., Frattoni, M., Di Palo, V., Valentini, R., Tirone, G., Seufert, G., Bertin, N., Hansen, U., Csiky, O., Lenz, R., and Sharma, M.: Emissions of reactive terpene compounds from orange orchards and their removal by within-canopy processes, J. Geophys. Res., 104, 8077-8094, 1999.

Coeur, C., Jacob, V., Foster, P., and Baussand, P.: Rate constant for the gas-phase reaction of hydroxyl radical with the natural hydrocarbon bornyl acetate, Int. J. Chem. Kinet., 30, 497-502, doi:10.1002/(SICI)1097-4601(1998)30:7<497::AIDKIN6>3.0.CO;2-N, 1998.

Cojocariu, C., Kreuzwieser, J., and Rennenberg, H.: Correlation of short-chained carbonyls emitted from Picea abies with physiological and environmental parameters, New Phytol., 162, 717727, doi:10.1111/j.1469-8137.2004.01061.x, 2004

Corchnoy, S. B. and Atkinson, R.: Kinetics of the gas-phase reactions of hydroxyl and nitrogen oxide $\left(\mathrm{NO}_{3}\right)$ radicals with 2carene, 1,8-cineole, p-cymene, and terpinolene, Envir. Sci. Tech. Lib., 24, 1497-1502, doi:10.1021/es00080a007, 1990.

Eyles, A., Bonello, P., Ganley, R., and Mohammed, C.: Induced resistance to pests and pathogens in trees, New Phytol., 185, 893908, doi:10.1111/j.1469-8137.2009.03127.x, 2010.

Fall, R.: Biogenic emissions of volatile organic compounds from higher plants, in: Reactive Hydrocarbons in the Atmosphere, edited by: Hewitt, C. N., San Diego, Academic Press, 43-96, 1999.

Ghirardo, A., Koch, K., Taipale, R., Zimmer, I., Schnitzler, J.-P., and Rinne, J.: Determination of de novo and pool emissions of terpenes from four common boreal/alpine trees by ${ }^{13} \mathrm{CO}_{2}$ labelling and PTR-MS analysis, Plant Cell Environ., 33, 781-792, 2010.

Gill, K. J. and Hites, R. A.: Rate Constants for the Gas-Phase Reactions of the Hydroxyl Radical with Isoprene, $\alpha$ - and $\beta$-Pinene, and Limonene as a Function of Temperature, J. Phys. Chem. A, 106, 2538-2544, doi:10.1021/jp013532q, 2002.
Grabmer, W., Kreuzwieser, J., Wisthaler, A., Cojocariu, C., Graus, M., Rennenberg, H., Steigner, D., Steinbrecher, R., and Hansel, A.: VOC emissions from Norway spruce (Picea abies L. [Karst]) twigs in the field - Results of a dynamic enclosure study, Atmos. Environ., 40, S128-S137, 2006.

Griffin, R. J., Cocker III, D. R., Flagan, R. C., and Seinfeld, J. H.: Organic aerosol formation from the oxidation of biogenic hydrocarbons, J. Geophys. Res., 104, 3555-3567, 1999.

Grosjean, E. and Grosjean, D.: Rate constants for the gasphase reaction of ozone with unsaturated oxygenates, Int. J. Chem. Kinet., 30, 21-29, doi:10.1002/(SICI)10974601(1998)30:1<21::AID-KIN3>3.0.CO;2-W, 1998.

Guenther, A. B., Zimmerman, P. R., Harley, P. C., Monson, R. K., and Fall, R.: Isoprene and monoterpene emission rate variability: Model evaluation and sensitivity analyses, J. Geophys. Res., 98, 12609-12627, 1993.

Guenther, A.: Seasonal and spatial variations in natural volatile organic compound emissions, Ecol. Appl., 7, 34-45, 1997.

Guenther, A. B., Jiang, X., Heald, C. L., Sakulyanontvittaya, T., Duhl, T., Emmons, L. K., and Wang, X.: The Model of Emissions of Gases and Aerosols from Nature version 2.1 (MEGAN2.1): an extended and updated framework for modeling biogenic emissions, Geosci. Model Dev., 5, 1471-1492, doi:10.5194/gmd-51471-2012, 2012.

Hakola, H., Rinne, J., and Laurila, T.: The hydrocarbon emission rates of Tea-Leaved Willow (Salix phylicifolia), Silver Birch (Betula pendula) and European Aspen (Populus tremula), Atmos. Environ., 32, 1825-1833, 1998.

Hakola, H., Laurila, T., Lindfors, V., Hellén, H., Gaman, A., and Rinne, J.: Variation of the VOC emission rates of birch species during the growing season, Boreal Environ. Res., 6, 237-249, 2001.

Hakola, H., Tarvainen, V., Laurila, T., Hiltunen, V., Hellén, H., and Keronen, P.: Seasonal variation of VOC concentrations above a boreal coniferous forest, Atmos. Environ., 37, 1623-1634, 2003.

Hakola, H., Tarvainen, V., Bäck, J., Ranta, H., Bonn, B., Rinne, J., and Kulmala, M.: Seasonal variation of mono- and sesquiterpene emission rates of Scots pine, Biogeosciences, 3, 93-101, doi:10.5194/bg-3-93-2006, 2006.

Hakola, H., Hellén, H., Hemmilä, M., Rinne, J., and Kulmala, M.: In situ measurements of volatile organic compounds in a boreal forest, Atmos. Chem. Phys., 12, 11665-11678, doi:10.5194/acp12-11665-2012, 2012.

Hansen, U. and Seufert, G.: Temperature and light dependence of $\beta$-caryophyllene emission rates, J. Geophys. Res., 108, 4801, doi:10.1029/2003JD003853, 2003.

Hari, P. and Kulmala, M.: Station for measuring ecosystematmosphere relations (SMEAR II), Boreal Env. Res., 10, 315322, 2005.

Hites, R. A. and Turner, A. M.: Rate constants for the gasphase $\beta$-myrcene $+\mathrm{OH}$ and isoprene $+\mathrm{OH}$ reactions as a function of temperature, Int. J. Chem. Kinet., 41, 407-413, doi:10.1002/kin.20413, 2009.

Holopainen, J. and Gershenzon, J.: Multiple stress factors and the emission of plant VOCs, Trends Plant Sci., 15, 176-184, 2010.

Jaoui, M., Kleindienst, T. E., Docherty, K. S., Lewandowski, M., and Offenberg, J. H.: Secondary organic aerosol formation from the oxidation of a series of sesquiterpenes: a-cedrene, b- 
caryophyllene, a-humuleneanda-farnesenewith $\mathrm{O}_{3}$, Hand $\mathrm{NO}_{3}$ radicals, Environ. Chem., 10, 178-193. 2013.

Jiménez, E., Lanza, B., Martínez, E., and Albaladejo, J.: Daytime tropospheric loss of hexanal and trans-2-hexenal: $\mathrm{OH}$ kinetics and UV photolysis, Atmos. Chem. Phys., 7, 1565-1574, doi:10.5194/acp-7-1565-2007, 2007.

Joutsensaari, J., Yli-Pirilä, P., Korhonen, H., Arola, A., Blande, J. D., Heijari, J., Kivimäenpää, M., Mikkonen, S., Hao, L., Miettinen, P., Lyytikäinen-Saarenmaa, P., Faiola, C. L., Laaksonen, A., and Holopainen, J. K.: Biotic stress accelerates formation of climate-relevant aerosols in boreal forests, Atmos. Chem. Phys., 15, 12139-12157, doi:10.5194/acp-15-12139-2015, 2015.

Kännaste, A., Vongvanich, N., and Borg-Karlson, A.-L.: Infestation by a Nalepella species induces emissions of $\mathrm{a}-$ and $\mathrm{b}$-farnesenes, (-)-linalool and aromatic compounds in Norway spruce clones of different susceptibility to the large pine weevil, Arthropod-Plant Inte., 2, 31-41, doi:10.1007/s11829-008-9029-4, 2008.

Kännaste, A., Nordenhem, H., Nordlander, G., and Borg-Karlson, A.-K.: Volatiles from a Mite-Infested Spruce Clone and Their Effects on Pine Weevil Behavior, J. Chem. Ecol., 35, 1262-1271, 2009.

Kesselmeier, J. and Staudt, M.: Biogenic volatile organic compounds (VOC): An overview on emission, physiology and ecology, J. Atmos. Chem., 33, 23-88, 1999.

Koppmann, R. and Wildt, J.: Oxygenated volatile organic compounds, in: Volatile organic compounds in the atmosphere, edited by: Koppmann, R., ISBN-13: 987-1-4051-3115-5, Blackwell Publishing, 129-173, 2007.

Kourtchev, I., Bejan, I., Sodeau, J. R., and Wenger, J. C.: Gas phase reaction of $\mathrm{OH}$ radicals with (E)- $\beta$-farnesene at $296 \pm 2 \mathrm{~K}$ : Rate coefficient and carbonyl products, Atmos. Environ., 46, 338-345, doi:10.1016/j.atmosenv.2011.09.061, 2012.

Loreto, F. and Schnitzler, J.-P.: Abiotic stresses and induced BVOCs, Trends Plant Sci., 15, 154-166, 2010.

Martin, D. M., Gershenzon, J., and Bohlmann, J.: Induction of Volatile Terpene Biosynthesis and Diurnal Emission by Methyl Jasmonate in foliage of Norway Spruce, Plant Physiol., 132, 1586-1599, 2003.

Niinemets, Ü.: Responses of forest trees to single and multiple environmental stresses from seedlings to mature plants: Past stress history, stress interactions, tolerance and acclimation, Forest Ecol. Manag., 260, 1623-1639, 2010.

Nölscher, A. C., Williams, J., Sinha, V., Custer, T., Song, W., Johnson, A. M., Axinte, R., Bozem, H., Fischer, H., Pouvesle, N., Phillips, G., Crowley, J. N., Rantala, P., Rinne, J., Kulmala, M., Gonzales, D., Valverde-Canossa, J., Vogel, A., Hoffmann, T., Ouwersloot, H. G., Vilà-Guerau de Arellano, J., and Lelieveld, J.: Summertime total $\mathrm{OH}$ reactivity measurements from boreal forest during HUMPPA-COPEC 2010, Atmos. Chem. Phys., 12, 8257-8270, doi:10.5194/acp-12-8257-2012, 2012.

Nölscher, A. C., Bourtsoukidis, E., Bonn, B., Kesselmeier, J., Lelieveld, J., and Williams, J.: Seasonal measurements of total $\mathrm{OH}$ reactivity emission rates from Norway spruce in 2011, Biogeosciences, 10, 4241-4257, doi:10.5194/bg-10-4241-2013, 2013.

Petterson, M.: Stress related emissions of Norway spruce plants, Licentiate thesis, KTH Royal Institute of Technology, Stockholm, ISBN-13: 978-91-7178-644-9, 2007.
Pinto-Zevallos, D., Hellén, H., Hakola, H., van Nouhuys, S., and Holopainen, J.: Herbivore-induced volatile organic compounds emitted by food plants of the Glanville Fritillary, Phytochem. Lett., 6, 653-656, 2013.

Rinne, J., Bäck, J., and Hakola, H.: Biogenic volatile organic compound emissions from Eurasian taiga: current knowledge and future directions, Boreal Env. Res., 14, 807-826, 2009.

Sanadze, G. A.: Biogenic isoprene (a review), Russ. J. Plant Physl.+, 51, 729-741, 2004.

Shu, Y. and Atkinson, R.: Atmospheric lifetimes and fates of a series of sesquiterpenes, J. Geophys. Res., 100, 7275-7281, doi:10.1029/95JD00368, 1995.

Sinha, V., Williams, J., Lelieveld, J., Ruuskanen, T., Kajos, M., Patokoski, J., Hellen, H., Hakola, H., Mogensen, D., Boy, M., Rinne, J., and Kulmala, M.: OH Reactivity Measurements within a Boreal Forest: Evidence for Unknown Reactive Emissions, Environ. Sci. Technol., 44, 6614-6620, doi:10.1021/es101780b, 2010

Spiess, A. and Neumeyer, N.: An evaluation of $R^{2}$ as an inadequate measure for nonlinear models in pharmacological and biochemical research: a Monte Carlo approach, BMC Pharmacology, 10, doi:10.1186/1471-2210-10-6, 2010.

Tarvainen, V., Hakola, H., Hellén, H., Bäck, J., Hari, P., and Kulmala, M.: Temperature and light dependence of the VOC emissions of Scots pine, Atmos. Chem. Phys., 5, 989-998, doi:10.5194/acp-5-989-2005, 2005.

Tarvainen, V., Hakola, H., Rinne, J., Hellén, H., and Haapanala, S.: Towards a comphrehensive emission inventory of terpenoids from boreal ecosystems, Tellus B, 59, 526-534, 2007.

Thévenet, R., Mellouki, A., and Le Bras, G.: Kinetics of $\mathrm{OH}$ and $\mathrm{Cl}$ reactions with a series of aldehydes, Int. J. Chem. Kinet., 32, 676-685, doi:10.1002/1097-4601(2000)32:11<676::AIDKIN3>3.0.CO;2-V, 2000.

Tunved, P., Hansson, H.-C., Kerminen, V.-M., Ström, J., Dal Maso, M., Lihavainen, H., Viisanen, Y., Aalto, P. P., Komppula, M., and Kulmala, M.: High natural aerosol loading over boreal forests, Science, 312, 261-263, 2006.

Vestenius, M., Hellén, H., Levula, J., Kuronen, P., Helminen, K. J., Nieminen, T., Kulmala, M., and Hakola, H.: Acidic reaction products of monoterpenes and sesquiterpenes in atmospheric fine particles in a boreal forest, Atmos. Chem. Phys., 14, 7883-7893, doi:10.5194/acp-14-7883-2014, 2014.

Vickers, C. E., Gershenzon, J., Lerdau, M. T., and Loreto, F.: A unified mechanism of action for volatile isoprenoids in plant abiotic stress, Nat. Chem. Biol., 5, 283-291, 2009.

Wildt, J., Kobel, K., Schuh-Thomas, G., and Heiden, A. C.: Emissions of oxygenated volatile organic compounds from plants, part II: Emissions of saturated aldehydes, J. Atmos. Chem., 45, 173196, 2003.

Yassaa, N., Song, W., Lelieveld, J., Vanhatalo, A., Bäck, J., and Williams, J.: Diel cycles of isoprenoids in the emissions of Norway spruce, four Scots pine chemotypes, and in Boreal forest ambient air during HUMPPA-COPEC-2010, Atmos. Chem. Phys., 12, 7215-7229, doi:10.5194/acp-12-7215-2012, 2012. 


\section{Paper III}





\title{
Semi-continuous gas and inorganic aerosol measurements at a boreal forest site: seasonal and diurnal cycles of $\mathrm{NH}_{3}$, $\mathrm{HONO}$ and $\mathrm{HNO}_{3}$
}

\author{
Ulla Makkonen"1), Aki Virkkula1)2), Heidi Hellén ${ }^{1)}$, Marja Hemmilä1), Jenni Sund"), \\ Mikko Äijälä2), Mikael Ehn²), Heikki Junninen²), Petri Keronen²), \\ Tuukka Petäjä2), Douglas R. Worsnop ${ }^{233)}$, Markku Kulmala ${ }^{2)}$ and \\ Hannele Hakola1)
}

\author{
1) Finnish Meteorological Institute, P.O. Box 505, Fl-00560, Helsinki, Finland \\ 2) Department of Physics, Fl-00014 University of Helsinki, Finland \\ 3) Aerodyne Research Inc., 45 Manning Rd, Billerica, MA 01821, USA
}

Received 31 Oct. 2013, final version received 17 Jan. 2014, accepted 10 Jan. 2014

Makkonen, U., Virkkula, A., Hellén, H., Hemmilä, M., Sund, J., Äijälä, M., Ehn, M., Junninen, H., Keronen, P., Petäjä, T., Worsnop, D. R., Kulmala, M. \& Hakola, H. 2014: Semi-continuous gas and inorganic aerosol measurements at a boreal forest site: seasonal and diurnal cycles of $\mathrm{NH}_{3}, \mathrm{HONO}$ and $\mathrm{HNO}_{3}$. Boreal Env. Res. 19 (suppl. B): 311-328.

In a boreal forest environment at Hyytiälä (SMEAR II station), Finland, from 21 June 2010 to 31 April 2011, concentrations of gases $\left(\mathrm{HCl}, \mathrm{HNO}_{3}, \mathrm{HONO}, \mathrm{NH}_{3}, \mathrm{SO}_{2}\right)$ and inorganic ions $\left(\mathrm{Cl}^{-}, \mathrm{NO}_{3}^{-}, \mathrm{SO}_{4}^{2-}, \mathrm{NH}_{4}^{+}, \mathrm{Na}^{+}, \mathrm{K}^{+}, \mathrm{Mg}^{2+}, \mathrm{Ca}^{2+}\right)$ in $\mathrm{PM}_{10}$ and $\mathrm{PM}_{25}$ particles were measured with an on-line ion chromatograph MARGA 2S. The MARGA data were compared with those of the filter samples and the Aerosol Mass Spectrometer. The linear-regression slopes derived from MARGA against the filter data were $0.98,1.08,0.50$ and 1.31 for $\mathrm{SO}_{2}, \mathrm{SO}_{4}{ }^{2-}, \mathrm{HNO}_{3}$ and $\mathrm{NO}_{3}{ }^{-}$, respectively. The respective coefficients of determination $\left(r^{2}\right)$ were $0.89,0.90,0.70$ and 0.93 . After installing a concentration column, improved values of cation slopes of $1.00,1.19,0.88,1.00,0.73$ and 0.89 for $\mathrm{NH}_{3}, \mathrm{NH}_{4}^{+}, \mathrm{Na}^{+}, \mathrm{K}^{+}, \mathrm{Mg}^{2+}$, and $\mathrm{Ca}^{2+}$, respectively, were obtained. The corresponding coefficients of determination $\left(r^{2}\right)$ were: $0.79,0.83,0.95,0.90,0.85$ and 0.62 . According to these results, traditional filter collection can be replaced with the MARGA instrument at background sites, if a concentration column is used at least for the cations. This would improve the temporal resolution of the observations. The average concentrations of nitrogen-containing gases were highest in the summer $\left(\mathrm{NH}_{3}: 0.47 \mathrm{ppb}, \mathrm{HNO}_{3}: 0.10 \mathrm{ppb}\right.$ and $\left.\mathrm{HONO}: 0.11 \mathrm{ppb}\right)$, which can be explained by the higher temperatures and increased amounts of sunlight followed by stronger agricultural and soil-related sources. In the summer, clear diurnal cycles were found in all $\mathrm{N}$-containing gases, but in the winter the concentrations remained low most of the time and no diurnal cycles were observed. The concentration of ammonia was found to depend exponentially on the prevailing temperature, the increase with temperature being strongest in dry conditions. 


\section{Introduction}

Nitrogen-containing gases are important contributors to atmospheric processes and to the formation and growth of new particles. The concentrations of aerosol species, such as ammonium nitrate $\left(\mathrm{NH}_{4} \mathrm{NO}_{3}\right)$, ammonium sulphate $\left[\left(\mathrm{NH}_{4}\right)_{2} \mathrm{SO}_{4}\right]$, ammonium bisulphate $\left(\mathrm{NH}_{4} \mathrm{HSO}_{4}\right)$ and ammonium chloride $\left(\mathrm{NH}_{4} \mathrm{Cl}\right)$, are strongly dependent on their gas-phase precursors, $\mathrm{NH}_{3}, \mathrm{HNO}_{3}, \mathrm{SO}_{2}$ and $\mathrm{HCl}$ (Finlayson-Pitts and Pitts 2000, Kirkby et al. 2011). Ammonia $\left(\mathrm{NH}_{3}\right)$ is the most abundant gaseous base in the atmosphere and has a major role in neutralizing acids and in the formation of new particles (Kirkby et al. 2011, Kulmala et al. 2000). In the atmosphere, ammonia can also react slowly with the hydroxyl radical $(\mathrm{OH})$, forming the amidogen radical $\left(\mathrm{NH}_{2}\right)$ which in turn reacts with nitrogen dioxide $\left(\mathrm{NO}_{2}\right)$ to form nitrous oxide $\left(\mathrm{N}_{2} \mathrm{O}\right)$ (Park and Lin 1997), one of the main warming components in the atmosphere (Butterbach-Bahl 2011). Furthermore, nitric acid interacts with crustal and sea salt aerosol, forming calcium and sodium nitrate $\left[\mathrm{Ca}\left(\mathrm{NO}_{3}\right)_{2}\right.$ and $\mathrm{NaNO}_{3}$ ]. The nitrogen-containing aerosols, as well as the sulphates, have a cooling effect on the climate through direct scattering of sunlight and through contribution to cloud formation (Sutton 2011). Nitrogen compounds participate both in the production and loss of the most important daytime atmospheric oxidant, the hydroxyl radical $(\mathrm{OH})$. The dissociation of HONO contributes to the production of $\mathrm{OH}$ radicals (e.g. Kulmala and Petäjä 2011, Su et al. 2011). During the daytime $\mathrm{OH}$ radicals are consumed to form nitric acid in the reaction: $\mathrm{NO}_{2}+\mathrm{OH} \bullet+\mathrm{M} \rightarrow \mathrm{HNO}_{3}+\mathrm{M}$ (Finlayson-Pitts and Pitts 2000).

There is still a lack of knowledge of the concentration of nitrogen-containing gases and their cycle in the ambient atmosphere (e.g., Su et al. 2011, Kulmala and Petäjä 2011), and until now no reliable semi-continuous measurements of ammonia have been performed in background areas of the Nordic countries. In this study, we measured gases and inorganic compounds in airborne particles with a 1-hour time-resolution using a commercially-available on-line ion chromatograph, MARGA 2S (The instrument for Measuring AeRosols and Gases in ambient Air; ten Brink et al. 2007), in a boreal forest. In the MARGA instrument, gases are collected by diffusion in a wet rotating denuder (WRD) and for collecting aerosols this instrument takes the advantage of the principle of the Steam-Jet Aerosol Collector (SJAC) (e.g. Khlystov et al. 1995). In an earlier publication, the performance of the MARGA $2 S$ instrument was evaluated in an urban environment (Makkonen et al. 2012, Rumsey et al. 2013). In a clean background environment in Europe, MARGA has previously been used at an EMEP (European Monitoring and Evaluation Programme) supersite in Scotland (Cape 2009). At the Finnish background stations, particles and inorganic gaseous compounds had earlier been measured with the EMEP filter-pack with a time resolution varying from 24 hours to several days (EMEP 2001, Ruoho-Airola et al. 2010). Using a semi-continuous instrument makes it possible to obtain data with short enough time resolution to characterize chemical processes, to evaluate models and to study sources, which would not be possible by using the traditional filter methods (Schaap et al. 2011, Aan de Brugh et al. 2012).

Concentrations of a suite of gases and aerosols were measured at a boreal forest measurement site in a large campaign, the "Hyytiälä United Measurements of Photochemistry and Particles in Air - Comprehensive Organic Precursor Emission Concentration 2010 (HUMPPA - COPEC-10)", in July-August 2010 (Williams et al. 2011). The general goal of the campaign was to study the links between gas-phase oxidation chemistry and particle properties and processes. During the campaign, the MARGA instrument was used to measure water-soluble gases and inorganic compounds in particles, and it was left running at Hyytiälä to study seasonal variations and possible sources or sinks of nitrogen-containing gases.

The first goal of this study was to evaluate whether the MARGA instrument could be used to replace the EMEP filter method at the background stations with low concentrations. In addition, we compared the MARGA results with those from an Aerosol Mass Spectrometer (AMS) (Jayne et al. 2000, Jimenez et al. 2003) that provides the concentrations of the major aerosol constituents (organics, sulphate, nitrate, ammonium, and chloride) of submicron aerosols with a high time resolution. 
The second goal of this work was to analyse the seasonal and diurnal cycles of nitrogen-containing trace gases $\mathrm{NH}_{3}, \mathrm{HNO}_{3}$ and $\mathrm{HONO}$. As explained above, these gases play an important role in atmospheric chemistry, yet their seasonal and diurnal cycles measured at our site with a high time resolution have not been presented before. The temperature dependence of ammonia will be compared with that found in other studies.

\section{Material and methods}

\section{Measurement site}

The measurements were carried out in Hyytiälä at the boreal forest research station SMEAR II (Station for Measuring Ecosystem-Atmosphere Relationships) from 21 June 2010 until 30 April 2011. The station $\left(61^{\circ} 51^{\prime} \mathrm{N}, 24^{\circ} 17^{\prime} \mathrm{E}\right)$ is situated in southern Finland, about $60 \mathrm{~km}$ NE of the city of Tampere. The station is surrounded by a coniferous Scots pine-dominated forest. A more detailed site description can be found in Hari and Kulmala (2005). The container in which the MARGA instrument was installed was air-conditioned and kept at a constant temperature of $20^{\circ} \mathrm{C}$. The container was located in a small clearing about 5 $\mathrm{m}$ from the nearest trees. The inlet of the instrument was situated on the roof of the container at a height of $2.5 \mathrm{~m}$ above the ground. The time used in this study is local winter time (UTC +2 hours).

\section{MARGA}

MARGA 2S ADI 2080 (Applikon Analytical BV, Netherlands) with two sample boxes was used in this study, in the same configuration as used in an earlier study in Helsinki (Makkonen 2012). Ambient air was drawn through a $\mathrm{PM}_{10}$-inlet (Teflon coated impactor, URG-2000-30DBN-TC, $2 \mathrm{~m}^{3} \mathrm{~h}^{-1}$ ) followed by a $50-\mathrm{cm}$-long polyethylene $(\mathrm{PE})$ tube $\left(\varnothing 1.0^{\prime \prime}\right)$ and divided into two flows, one going to the $\mathrm{PM}_{10}$ sample box through a 40 -cm-long PE tubing $\left(\varnothing 0.5^{\prime \prime}\right)$, while the other was directed through a $70-\mathrm{cm}$-long PE tube $(\varnothing$ $\left.0.5^{\prime \prime}\right)$ and $\mathrm{PM}_{2.5}$ cyclone $\left(1 \mathrm{~m}^{3} \mathrm{~h}^{-1}\right.$ Teflon coated, URG-2000-30ENB) into the $\mathrm{PM}_{2.5}$ sample box. In both compartments, the air was led through a Wet Rotating Denuder (WRD) where watersoluble gases diffuse to the absorption solution (10 ppm hydrogen peroxide). Subsequently the ambient particles were collected in a Steam Jet Aerosol Collector (SJAC) (Slanina et al. 2001). Hourly samples collected in syringes were analyzed with a Metrohm cation and anion chromatograph using an internal standard $(\mathrm{LiBr})$. The sample-stream was directed through the cation side to the anion IC and samples were injected simultaneously to both ICs. At the beginning of the measurements, cations were separated in a Metrosep C4 (100/4.0) cation column using 3.2 mmol ${ }^{-1} \mathrm{HNO}_{3}$ eluent. On 18 August 2010, the cation loop was replaced with a concentration column (Metrosep C PCC 1 VHC) and the $\mathrm{HNO}_{3}$ eluent was replaced with a methane sulfonic acid eluent ( $2.1 \mathrm{ml}$ MSA in 101 water) to get a better baseline for nitrate. For anions a Metrosep A Supp $10(75 / 4.0)$ column and a $\mathrm{Na}_{2} \mathrm{CO}_{3} / \mathrm{NaHCO}_{3}$ ( $7 \mathrm{mmol} \mathrm{l}^{-1} / 8 \mathrm{mmol} \mathrm{l}^{-1}$ ) eluent was used. Gases $\left(\mathrm{HCl}, \mathrm{HNO}_{3}, \mathrm{HONO}, \mathrm{NH}_{3}, \mathrm{SO}_{2}\right.$ ) and inorganic ions $\left(\mathrm{Cl}^{-}, \mathrm{NO}_{3}^{-}, \mathrm{SO}_{4}^{2-}, \mathrm{NH}_{4}^{+}, \mathrm{Na}^{+}, \mathrm{K}^{+}, \mathrm{Mg}^{2+}, \mathrm{Ca}^{2+}\right)$ in the $\mathrm{PM}_{10}$ and in $\mathrm{PM}_{2.5}$ particles were measured with the MARGA 2S. The instrument is described in more detail by Makkonen et al. (2012). For the data before 18 August 2010, field blanks of nitrate were subtracted from the initial $\mathrm{NO}_{3}{ }^{-}$and $\mathrm{HNO}_{3}$ values, but other field blanks were close to the DLs. Approximately every three weeks the inlet tubes, WRDs and SJACs were replaced with clean ones or cleaned. The SJAC was cleaned in diluted $\mathrm{HNO}_{3}$ in an ultrasonic bath, rinsed with ethanol and well rinsed with ultrapure water (Milli-Q conductivity $<18 \mu \mathrm{S} \mathrm{cm} \mathrm{cm}^{-1}$ ). The outer glass cylinder of WRD was detached and all the parts were washed with hot water, rinsed with ethanol and rinsed several times with ultrapure water to prevent any biological growth.

\section{Filter sampling}

The results from MARGA were compared with those of the EMEP filter-pack (EMEP 2001), which consists of three filters: the first is a Teflon filter for collecting particles, the second is a $\mathrm{NaOH}$-impregnated cellulose filter (Whatman 40) for collecting $\mathrm{SO}_{2}$ and $\mathrm{HNO}_{3}$, and the third is an oxalic-acid-impregnated cellulose filter 
(Whatman 40) for collecting $\mathrm{NH}_{3}$. The sampling time (flow $1 \mathrm{~m}^{3} \mathrm{~h}^{-1}$ ) was 2-3 days. The filters were extracted in ultrapure water (Milli-Q) and analysed by ion chromatographs (Waters and Dionex). The procedure is described in detail in the EMEP Manual (EMEP 2001). The averages of the corresponding time periods were calculated from the MARGA data and compared with the filter data.

\section{AMS}

The Aerodyne Aerosol Mass Spectrometer (AMS) measures aerosol particle chemical composition directly and quantitatively, using time-of-flight mass spectrometry (Jayne et al. 2000, Jimenez et al. 2003). An aerodynamic lens is used to focus aerosol particles of around 40-600 nm size (Liu et al. 2007) into a beam, and a thermal vaporization element at the temperature of $600{ }^{\circ} \mathrm{C}$ is used to flash-vaporize all non-refractory compounds in the sample, and electron impact ionization (EI) of $70 \mathrm{eV}$ ionizes the formed sample gas. Finally, a time-of-flight mass spectrometer is used to produce a mass spectrum of the sampled aerosol particles and remaining carrier gas. The ambient aerosol concentration and composition is obtained using data inversion and analysis. The data is corrected for instrument collection efficiency (CE), which was unaffected by aerosol acidity related effects for most of the measurement period and was determined to be around 0.43 .

The specific AMS used in this study features a compact time-of-flight $(\mathrm{C}-\mathrm{ToF})$ mass analyzer, the specifics of which are described by Drewnick et al. (2005). The particle time-of-flight (PToF) chamber was shorter than on a normal AMS, increasing ion signals at the expense of sizesegregated chemistry measurements.

\section{Results and discussion}

\section{Comparison of MARGA with independent methods}

\section{MARGA versus EMEP filter pack}

The EMEP filter-pack samples were collected in
Hyytiälä with a sampling time of 2-3 days. Averages of the MARGA data were calculated for the same periods. Before the averaging, the zerovalues found in the online data were replaced with $0.005 \mu \mathrm{g} \mathrm{m}^{-3}$. A linear regression (Fig. 1) MARGA $v s$. filter yielded slopes of $0.98\left(r^{2}=\right.$ $0.89)$ and $1.08\left(r^{2}=0.90\right)$ for $\mathrm{SO}_{2}$ and $\mathrm{SO}_{4}{ }^{2-}$ concentrations, respectively. For these compounds MARGA compared well also in the earlier studies in Helsinki, where the concentrations were higher, yielding slopes of 0.90 (MARGA vs. TEI 43iTL monitor) for $\mathrm{SO}_{2}$ and 0.85 for $\mathrm{SO}_{4}^{2-}$ (Makkonen et al. 2012).

The concentrations of $\mathrm{HNO}_{3}$ were clearly lower in MARGA than in the filter pack (slope $0.50, r^{2}=0.70$ ), while the concentrations of $\mathrm{NO}_{3}{ }^{-}$were higher in MARGA than with the filter method (slope $1.31, r^{2}=0.93$ ), yielding a regression slope of $0.97\left(r^{2}=0.89\right)$ for the sum $\mathrm{HNO}_{3}+$ $\mathrm{NO}_{3}{ }^{-}$. Based on this result and because of the sticky nature of $\mathrm{HNO}_{3}$, it is likely that a significant fraction of $\mathrm{HNO}_{3}$ had been attached to the walls of the PE-tubing. This hypothesis is supported by the study of Rumsey et al. (2013): the regression analysis of $\mathrm{HNO}_{3}$ concentrations of MARGA and the results of the denuder yielded slopes of $0.73\left(r^{2}=0.88\right)$ and $0.57\left(r^{2}=0.88\right)$. A better tubing material for collecting $\mathrm{HNO}_{3}$ would have been perfluoroalkoxy Teflon, as recommended by Neuman et al. (1999). However, this is not a suitable material for collecting particles which are retained on Teflon walls by electrostatic forces. Furthermore, it is likely, especially on warm summer days, that the $\mathrm{HNO}_{3}$ measured by Teflon filter was also underestimated: part of the $\mathrm{NH}_{4} \mathrm{NO}_{3}$ may have been volatilized from the Teflon front filters and moved to the next filters used for collecting gases. Because of these artifacts in the filter sampling, only the sums of $\mathrm{HNO}_{3}+\mathrm{NO}_{3}^{-}$and $\mathrm{NH}_{3}+\mathrm{NH}_{4}^{+}$are reported to the EMEP database (EMEP 2001).

The regression slopes of all the cations improved remarkably after removing the cation loop $(500 \mu \mathrm{l})$ and installing the concentration column on 18 August 2010 (Fig. 2). The regression slopes with the ordinary loop and with the concentration column were 1.50 and 0.88 , respectively, for $\mathrm{Na}^{+}, 1.51$ and 1.00 for $\mathrm{K}^{+}$, 3.39 and 0.73 for $\mathrm{Mg}^{2+}, 2.95$ and 0.89 for $\mathrm{Ca}^{2+}$ and 1.23 and 1.19 for $\mathrm{NH}_{4}^{+}$. The coefficients 
Fig. 1. Comparison of sulphur dioxide, sulphate, nitric acid and nitrate (with the $\mathrm{PM}_{10}$ inlet) concentrations measured with MARGA with those analysed from the EMEP filter-pack samples.
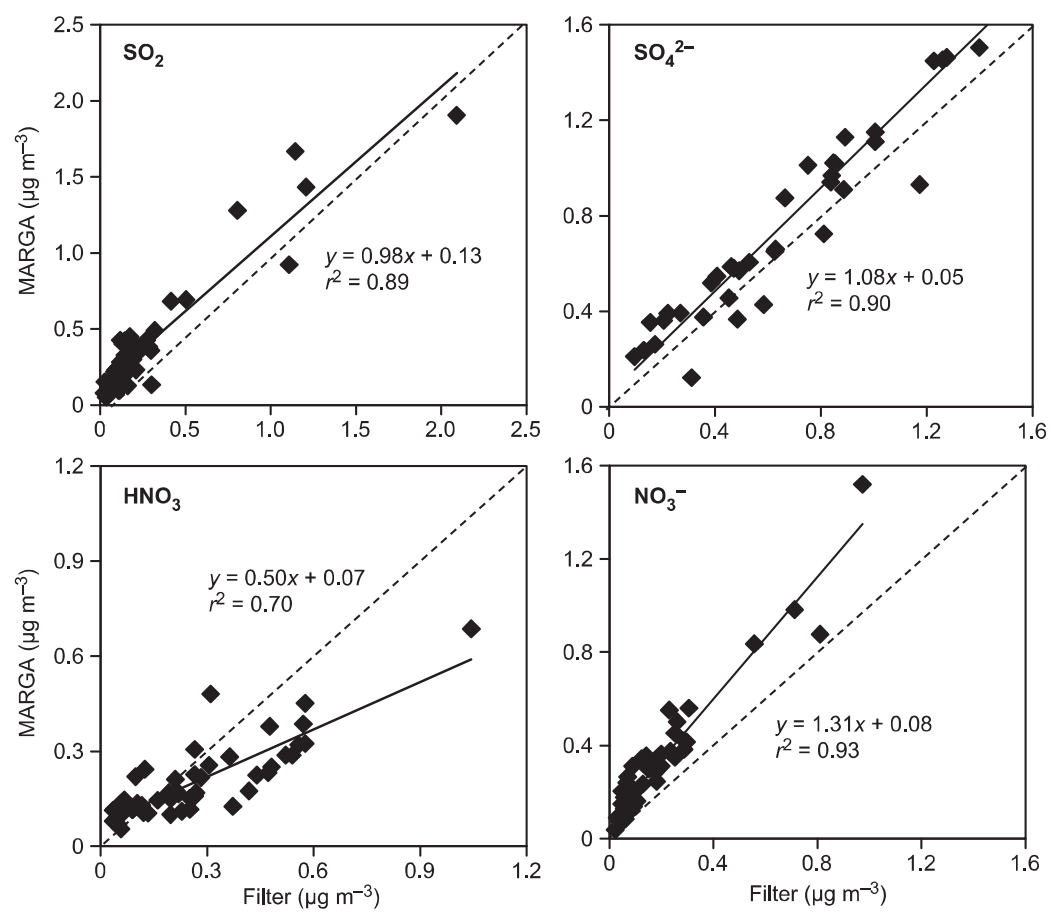

of determination were also improved with the concentration column $\left(r^{2}=0.83-0.95\right)$, except for $\mathrm{Mg}^{2+}\left(r^{2}=0.85\right)$ and $\mathrm{Ca}^{2+}\left(r^{2}=0.62\right)$ that had very low concentrations throughout the winter. Although the time resolution increases when an online instrument was used, we must also take into account that the measurement uncertainty increases at low concentrations. It must be noted that especially the cation peaks were often close or even under the official detection limits of MARGA.

\section{MARGA versus AMS}

The hourly-averaged AMS data were compared with the $\mathrm{PM}_{2.5}$ data of MARGA (Fig. 3). The sulphate concentrations measured with MARGA were in good agreement with those measured with AMS. The slope for the MARGA vs. AMS linear regression was 1.01 (intercept $-0.25, r^{2}=$ 0.92 ), which indicates that sulphate was mainly in submicron particles. The MARGA ammonium data values were in general higher than those measured with AMS (slope 0.66, intercept -0.02 ), indicating that a considerable fraction of the ammonium was in particles larger than $1 \mu \mathrm{m}$. For nitrate, there was not such a good an agreement between MARGA and AMS. The concentrations measured with AMS were often higher than those measured with MARGA. However, during the same period, the nitrate concentrations measured with MARGA were in good agreement with the EMEP filter data $\left(r^{2}=\right.$ 0.87 and 0.93 for $\mathrm{PM}_{2.5}$ and $\mathrm{PM}_{10}$, respectively). Nitrate concentrations were relatively low during the AMS measurement periods, which caused additional scatter. It is also possible that a slight offset may have arisen if the response to organic nitrates was lower in the MARGA and filter data compared with the AMS data. It should also be noted that the $\mathrm{NO}_{3}$ blank which was subtracted from all the MARGA results may have not been constant during the whole measurement period and may have caused further inaccuracy.

\section{Seasonal variations}

The measurement data were divided into four classes by the season (Table 1). The season division was made according to prevailing temperatures (thermal seasons). On 15 August the temperature decreased from $19{ }^{\circ} \mathrm{C}$ to $14{ }^{\circ} \mathrm{C}$ and 

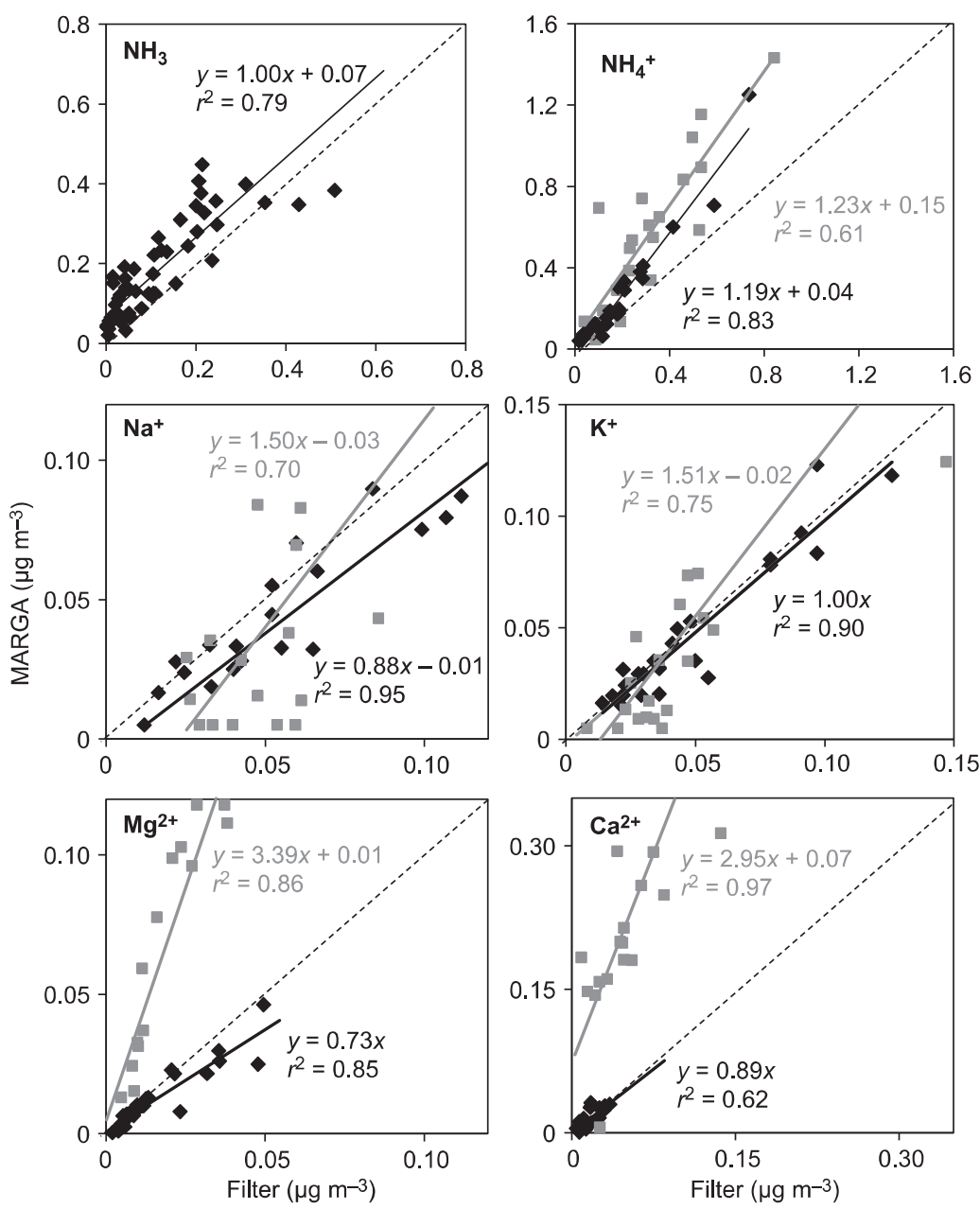

Fig. 2. Comparison of ammonia, ammonium, sodium, potassium, magnesium and calcium concentrations measured with MARGA with the $\mathrm{PM}_{10}$ inlet with those analysed from the EMEP filterpack samples. The concentrations obtained with MARGA were measured using an ordinary $500 \mu$ cation loop (grey) and a cation pre-concentration column (black).
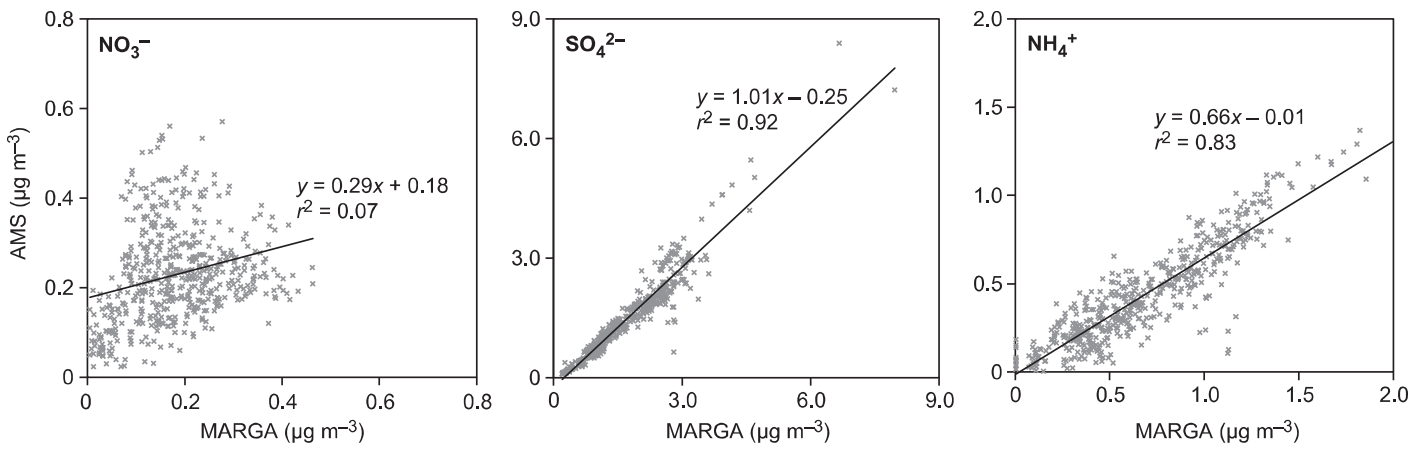

Fig. 3. Comparison of nitrate, sulphate, and ammonium concentrations measured with MARGA (using the $P M_{25}$ inlet) with those measured with AMS. The cutoff diameter for the AMS is below $1.0 \mu \mathrm{m}$.

on 24 August it was already below $10^{\circ} \mathrm{C}$. In this analysis the autumn period was therefore defined as starting on 16 August. On 6 November the temperature dropped below $0{ }^{\circ} \mathrm{C}$, starting the winter period. On 4 March the daily average temperature rose above $0{ }^{\circ} \mathrm{C}$ for the first time, starting the spring period, although the temperature remained close to $0{ }^{\circ} \mathrm{C}$ for the rest of March 
(Fig. 4). The ground was covered with snow (up to $0.75 \mathrm{~m}$ ) from 8 November 2010 until late April 2011. Gaps in the measurement data were caused mainly by technical problems and maintenance operations.

In the winter, sulphur dioxide was the dominating trace gas (average $0.49 \mathrm{ppb}$; Table 2), whereas concentrations of all the nitrogencontaining gases were low (averages 0.05-0.07 $\mathrm{ppb}$ ). The $\mathrm{SO}_{2}$ concentration was elevated during a short, cold period (14-24 February 2011) when the daily average temperature remained below $-20{ }^{\circ} \mathrm{C}$ (Fig. 4). The highest $\mathrm{SO}_{2}$ concentration was measured during this period, $20 \mathrm{ppb}$ on 18 February at 12:00. The simultaneously measured sulfate concentration in $\mathrm{PM}_{10}$ was $0.13 \mu \mathrm{g} \mathrm{m}^{-3}$, which is less than the median concentration of $0.70 \mu \mathrm{g} \mathrm{m}^{-3}$ throughout the whole period discussed in this paper, which suggests that the origin of the observed high $\mathrm{SO}_{2}$ concentrations was not a large-scale industrial source. In addition, back trajectories calculated with HYSPLIT (Draxler and Rolph 2013, Rolph 2013) show that air masses had come from the east-north-east and not over some of the largest $\mathrm{SO}_{2}$ emitters in the Kola Peninsula. A possible source of $\mathrm{SO}_{2}$ was the domestic heating with wood-burning stoves and oil burners - the period was cold, a situation which is often associated with strong inversions. Further meteorological analyses are omitted in this paper, however. Another indicator for domestic burning would be black carbon, which was also measured at SMEAR II. However, during February 2011 the black carbon instrument was out of order so it could not be used for confirming the source either.

The average $\mathrm{HNO}_{3}$ concentration measured at Hyytiälä was at the same level (0.07 ppb) as the average concentration measured with MARGA in southeastern Scotland in 2007 (0.05 ppb; Cape 2009), but much lower than those measured at urban sites in Helsinki $(0.13 \mathrm{ppb}$ in winter and $0.22 \mathrm{ppb}$ in spring; Makkonen et al. 2012). The highest seasonal average $\mathrm{HNO}_{3}$ concentration, $0.10 \mathrm{ppb}$, occurred in summer, confirming that the formation of nitric acid requires nitrogen dioxide and solar radiation. High concentrations were occasionally observed also at the darkest time of the year. For instance, during an episode when winds blew over a local sawmill about $5 \mathrm{~km}$ to the south-southeast of SMEAR II on 17-22 December, short $\mathrm{NO}_{2}$ peaks as high as $25 \mathrm{ppb}$ and $\mathrm{HNO}_{3}$ peaks up to $0.38 \mathrm{ppb}$ were detected, in addition to elevated monoterpene and aromatic hydrocarbon concentrations (Hakola et al. 2012).

The seasonal cycle of nitrous acid, HONO, was also very clear (Fig. 4). The highest concentrations were recorded in summer, which conforms with the observation that soil nitrite is a strong source of atmospheric HONO ( $\mathrm{Su}$ et al. 2011). $\mathrm{NO}_{\mathrm{x}}$ emitted by road traffic has been shown to be another important source of HONO. Kurtenbach et al. (2001) investigated the emissions and heterogeneous formation of $\mathrm{HONO}$ in a road traffic tunnel and found that the mean HONO-to-NO $\mathrm{Natio}_{\mathrm{x}}$ was $0.008 \pm 0.001$. We operated the same MARGA instrument at the urban background SMEAR III site in Helsinki in 2009-2010 and found that most of the time there was at least as much $\mathrm{HONO}$ as the Kurtenbach et al. (2001) HONO-to-NO ratio predicts (Makkonen et al. 2012). From the measured ratios it was also deduced that traffic was not the only source of HONO at the urban site. The same approach is used here for the SMEAR II data. The HONO vs. $\mathrm{NO}_{\mathrm{x}}$ concentrations, the latter obtained from the SMEAR II mast at the altitude of $8.4 \mathrm{~m}$, clearly form two groups: in summer the ratio deviates by up to two orders of magnitude from the traffic ratio of Kurtenbach et al (2001), suggesting possible HONO emissions from the boreal soil in line with the observations by $\mathrm{Su}$ et al. (2011). In the other seasons, the ratio was closer to the traffic ratio (Fig. 5). As in the urban data, HONO concentrations were very rarely smaller than those predicted by the $\mathrm{NO}_{x}$ concentration using the ratio by Kurtenback et al. (2001).

There was a clear seasonal cycle in the ammonia and ammonium concentrations: they were

Table 1. Dates determining the four seasons.

\begin{tabular}{ll}
\hline Season & Period \\
\hline Summer & 22 June 2010-15 August 2010 \\
Autumn & 16 August 2010-5 November 2010 \\
Winter & 6 November 2010-3 March 2011 \\
Spring & 4 March 2011-30 April 2011 \\
\hline
\end{tabular}




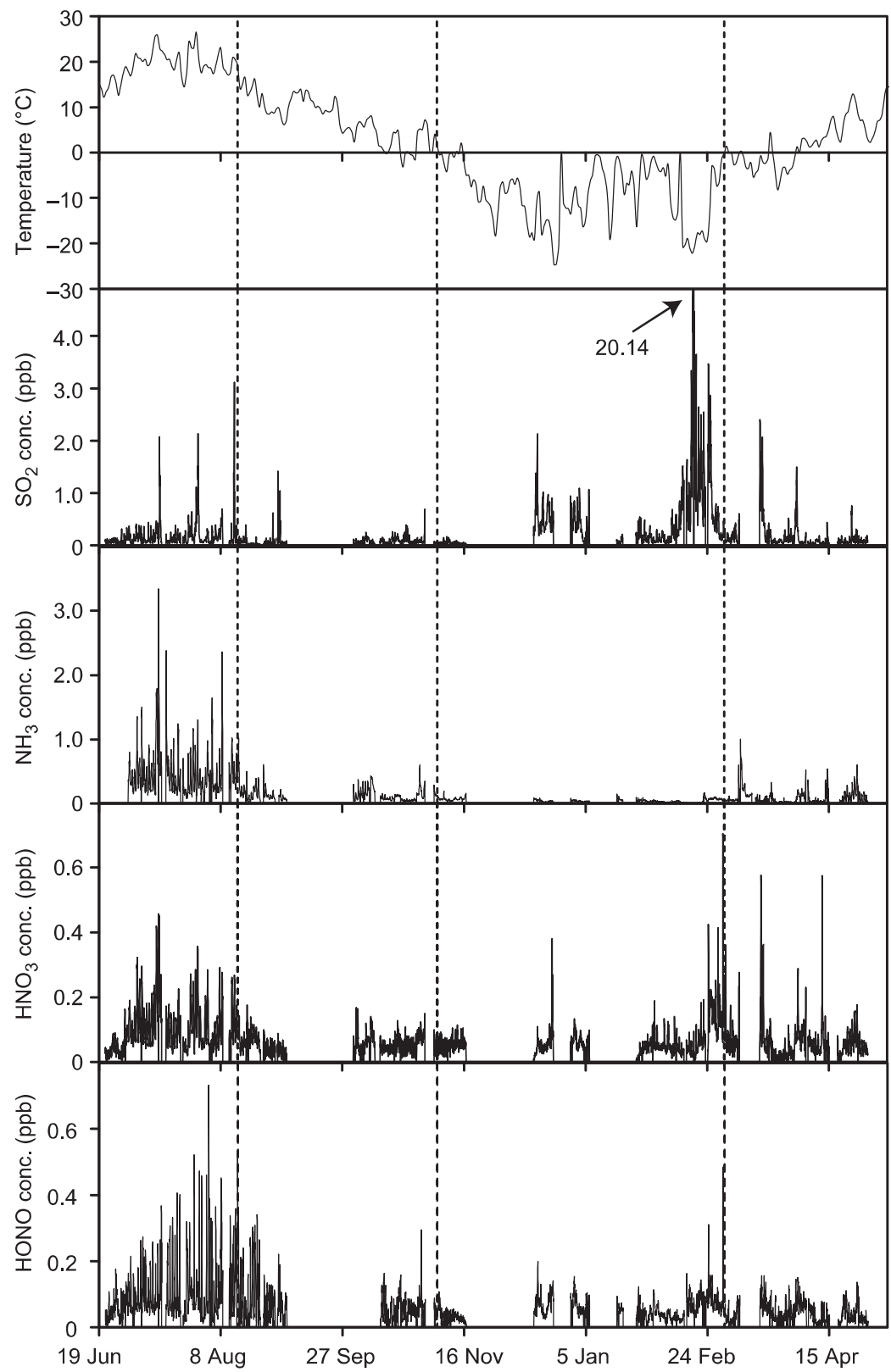

Fig. 4. Hourly-averaged temperature and gas concentrations at Hyytiälä from 22 June 2010 to 30 April 2011. highest in summer and decreased towards winter, increasing again in spring (Fig. 4), following the temperature profile of the same period. During the coldest months when temperature was below $0{ }^{\circ} \mathrm{C}$ and the land was covered with snow, ammonia concentrations remained near the detection limit (the winter $\mathrm{NH}_{3}$ average $0.05 \mathrm{ppb}, \mathrm{NH}_{4}^{+}$ $0.38 \mu \mathrm{g} \mathrm{m}^{-3}$ ). In summer and autumn, the average ammonia concentrations were higher $(0.47$ and $0.13 \mathrm{ppb}$, respectively) than concentrations of the acidic gases $\mathrm{SO}_{2}(0.18$ and $0.08 \mathrm{ppb})$, $\mathrm{HONO}\left(0.11\right.$ and $0.07 \mathrm{ppb}$ ) and $\mathrm{HNO}_{3}$ (0.10 and $0.06 \mathrm{ppb}$ ). Due to lower acid concentrations and warmer weather, ammonia was partitioned more to the gas phase in summer than in winter when there was an excess of acidic gases. A similar seasonal variation can be seen at all northern EMEPstations where $\mathrm{NH}_{3}$ is being measured using the 
filter method, as well as in Canada (Zbieranowski and Aherne 2012). The main reason for the seasonal variation is that the agricultural sources of $\mathrm{NH}_{3}$ are lower during the cold period. In Finland, agricultural outdoor activities normally start in May, leading to increased ammonia concentrations (Ruoho-Airola et al. 2010). In addition, at lower temperatures ammonia and nitric acid are usually in the form of ammonium nitrate, while at higher temperatures ammonium nitrate particles are easily volatilized according to $\mathrm{NH}_{3}+\mathrm{HNO}_{3}$ $\leftrightarrow \mathrm{NH}_{4} \mathrm{NO}_{3}$.

In the aerosol phase, ammonium sulfate and nitrate, which are typical long-range transported species, were the most abundant compounds, and $\mathrm{NH}_{4}^{+}$concentration followed the profiles of $\mathrm{SO}_{4}^{2-}$ and $\mathrm{NO}_{3}^{-}$(Fig. 6). Because the vapor pressure of ammonia over an acidic ammonium sulphate is much lower than that over ammonium

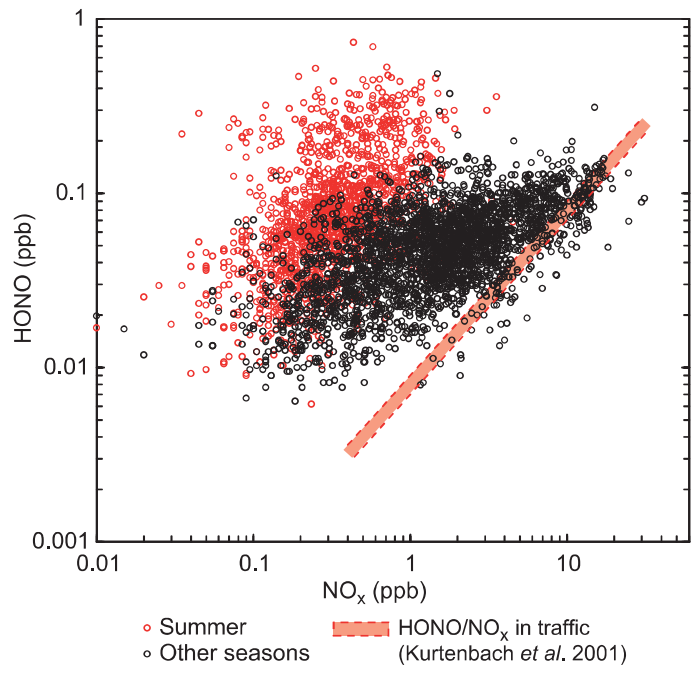

Fig. 5. Nitrous acid as a function of $\mathrm{NO}_{x}$ in summer and in the other seasons. The shaded red line shows the $\mathrm{HONO}$-to- $\mathrm{NO}_{x}$ ratios $0.008 \pm 0.001$ found by Kurtenbach et al. (2001) in road traffic.

Table 2. Statistical summary of the trace gas data measured with MARGA at SMEAR II on 22 June 2010-30 April 2011. $n$ = number of valid hourly results, $n_{\text {tot }}=$ total number of hours in the period. Hydrochloric acid concentrations were not included as they were below the detection limit for most of the time and even $95 \%$ of values were below $0.04 \mathrm{ppb}$.

\begin{tabular}{|c|c|c|c|c|c|}
\hline & \multirow{2}{*}{$\begin{array}{c}\text { Mean } \pm \text { SD } \\
(p p b)\end{array}$} & \multicolumn{3}{|c|}{ Percentiles (ppb) } & \multirow[t]{2}{*}{$n / n_{\text {tot }}$} \\
\hline & & 5 & 50 & 95 & \\
\hline \multicolumn{6}{|l|}{ All data } \\
\hline HONO & $0.07 \pm 0.06$ & 0.02 & 0.05 & 0.19 & $4396 / 7422$ \\
\hline $\mathrm{SO}_{2}$ & $0.25 \pm 0.58$ & 0.03 & 0.10 & 0.95 & $4736 / 7422$ \\
\hline $\mathrm{HNO}_{3}$ & $0.07 \pm 0.06$ & 0.02 & 0.06 & 0.19 & $4665 / 7422$ \\
\hline $\mathrm{NH}_{3}$ & $0.18 \pm 0.24$ & 0.02 & 0.08 & 0.63 & $4323 / 7422$ \\
\hline \multicolumn{6}{|l|}{ Summer } \\
\hline HONO & $0.11 \pm 0.09$ & 0.02 & 0.07 & 0.31 & $1145 / 1331$ \\
\hline $\mathrm{SO}_{2}$ & $0.18 \pm 0.24$ & 0.04 & 0.11 & 0.50 & $1159 / 1331$ \\
\hline $\mathrm{HNO}_{3}$ & $0.10 \pm 0.07$ & 0.03 & 0.08 & 0.25 & $1156 / 1331$ \\
\hline $\mathrm{NH}_{3}$ & $0.47 \pm 0.36$ & 0.15 & 0.36 & 1.18 & $942 / 1331$ \\
\hline \multicolumn{6}{|l|}{ Autumn } \\
\hline HONO & $0.07 \pm 0.05$ & 0.02 & 0.06 & 0.19 & $844 / 1967$ \\
\hline $\mathrm{SO}_{2}$ & $0.08 \pm 0.09$ & 0.02 & 0.06 & 0.18 & $1083 / 1967$ \\
\hline $\mathrm{HNO}_{3}$ & $0.06 \pm 0.03$ & 0.02 & 0.05 & 0.10 & $1085 / 1967$ \\
\hline $\mathrm{NH}_{3}$ & $0.13 \pm 0.09$ & 0.04 & 0.11 & 0.33 & $1063 / 1967$ \\
\hline \multicolumn{6}{|l|}{ Winter } \\
\hline HONO & $0.06 \pm 0.03$ & 0.02 & 0.05 & 0.11 & $1457 / 2832$ \\
\hline $\mathrm{SO}_{2}$ & $0.49 \pm 0.94$ & 0.03 & 0.24 & 1.69 & $1483 / 2832$ \\
\hline $\mathrm{HNO}_{3}$ & $0.07 \pm 0.05$ & 0.02 & 0.05 & 0.17 & $1433 / 2832$ \\
\hline $\mathrm{NH}_{3}$ & $0.05 \pm 0.03$ & 0.02 & 0.05 & 0.10 & $1394 / 2832$ \\
\hline \multicolumn{6}{|l|}{ Spring } \\
\hline HONO & $0.05 \pm 0.03$ & 0.01 & 0.04 & 0.10 & $950 / 1392$ \\
\hline $\mathrm{SO}_{2}$ & $0.16 \pm 0.26$ & 0.03 & 0.09 & 0.58 & $1011 / 1392$ \\
\hline $\mathrm{HNO}_{3}$ & $0.06 \pm 0.06$ & 0.02 & 0.05 & 0.16 & $991 / 1392$ \\
\hline $\mathrm{NH}_{3}$ & $0.11 \pm 0.11$ & 0.02 & 0.07 & 0.33 & $924 / 1392$ \\
\hline
\end{tabular}



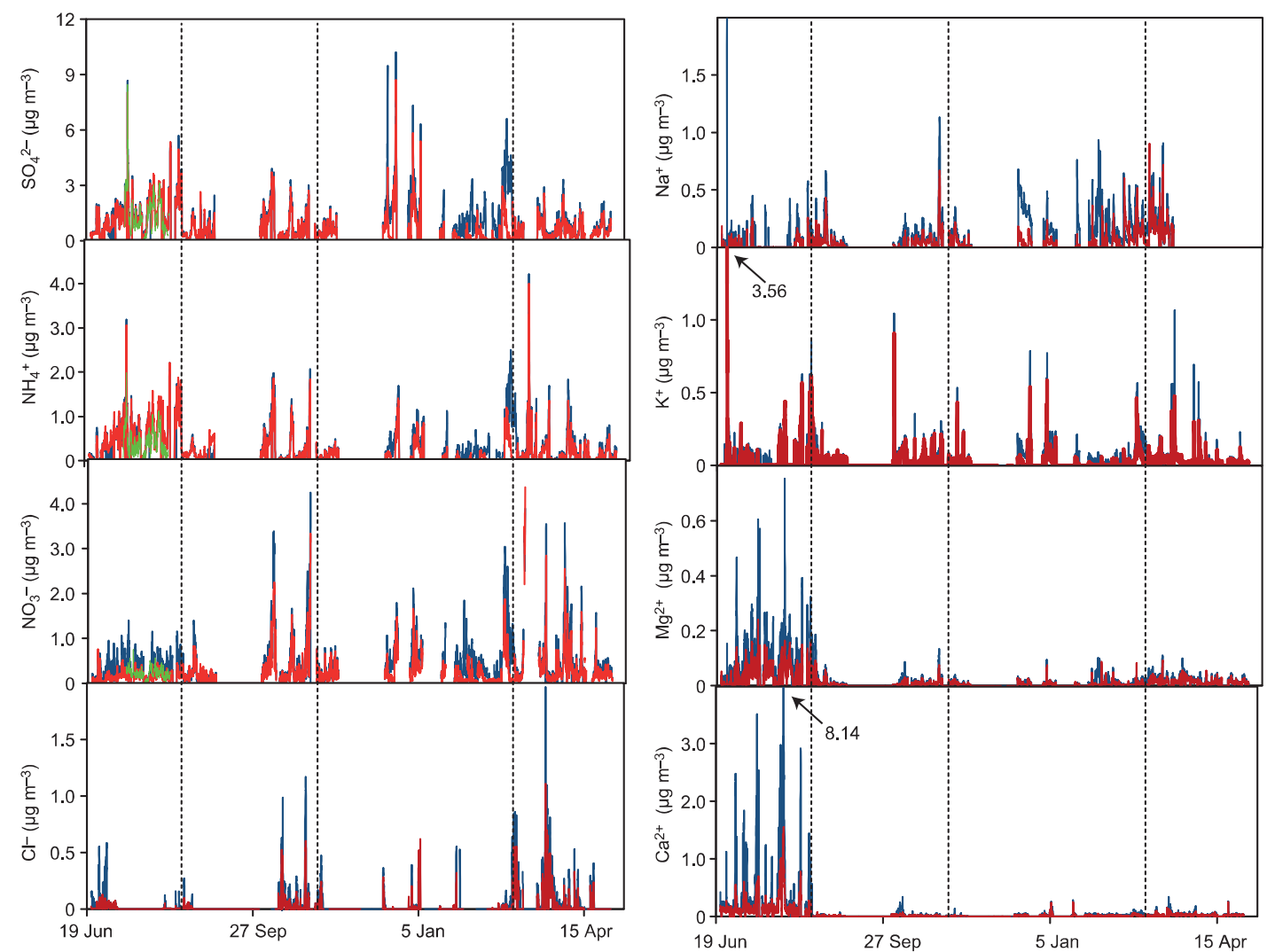

Fig. 6. Hourly-averaged concentrations of inorganic ions in $\mathrm{PM}_{2.5}$ (red) and $\mathrm{PM}_{10}$ (blue) at Hyytiälä from 22 June 2010 to 30 April 2011. AMS data (cut-off $\sim 1 \mu \mathrm{m}$ ) are presented in green.

nitrate, excess of ammonia leads to formation of ammonium nitrate, while the excess of acid sulphates leads to decomposition of ammonium nitrate (Ferm et al. 2012).

Concentrations of potassium, magnesium and calcium were very low in winter and spring (averages 0.02-0.07 $\mu \mathrm{g} \mathrm{m}^{-3}$; Table 3). The highest concentration of potassium $\left(2.6 \mu \mathrm{g} \mathrm{m}^{-3}\right.$ in $\mathrm{PM}_{2.5}$ and $3.6 \mu \mathrm{g} \mathrm{m}^{-3}$ in $\mathrm{PM}_{10}$ ) occurred on 25 June 2010, caused by the traditional Midsummer bonfires. Simultaneously, magnesium, calcium, sulphate and nitrate concentrations were elevated. On 1 January 2011, the fireworks of the New Year celebration caused $\mathrm{K}^{+}, \mathrm{Mg}^{2+}, \mathrm{Na}^{+}, \mathrm{Cl}^{-}$ and $\mathrm{SO}_{4}{ }^{2-}$ peaks (Fig. 6).

\section{Diurnal cycles of nitrogen-containing gases}

Nitric acid $\left(\mathrm{HNO}_{3}\right)$ is formed in the reaction $\mathrm{NO}_{2}$
$+\mathrm{OH} \bullet+\mathrm{M} \rightarrow \mathrm{HNO}_{3}+\mathrm{M}$, where the hydroxyl radical $\mathrm{OH} \bullet$ is formed in photochemical reactions in sunlight (Finlayson-Pitts and Pitts 2000). This is in agreement with our observations: in summer there was a clear diurnal cycle, with the maximum reached in the afternoon at 14:00 18:00 (Fig. 7). However, the peak concentration was observed several hours later than expected, since OH-radicals producing $\mathrm{HNO}_{3}$ from $\mathrm{NO}_{2}$ reached their highest concentrations at noon (Petäjä et al. 2009).

Nitrous acid $\mathrm{HONO}$ is formed in the reaction $\mathrm{NO}+\mathrm{OH} \bullet+\mathrm{M} \rightarrow \mathrm{HONO}+\mathrm{M}$ and dissociated by solar radiation: $\mathrm{HONO}+h v \rightarrow \mathrm{OH} \bullet+\mathrm{NO}$ (Finlayson-Pitts and Pitts 2000). Concentrations of HONO are thus higher at night and lower in sunlight. In Hyytiälä, the diurnal variation of the HONO concentrations was negligible during winter and also very modest during spring. As discussed above, the HONO-to- $\mathrm{NO}_{\mathrm{x}}$ ratios suggest that a significant fraction of the recorded 
HONO had been emitted from the soil. These data do not explain whether there was also a diurnal cycle in the emission rate or whether the cycle was only due to photochemistry.

In summer, the diurnal variation of the ammonia concentration was large, with a maximum in the afternoon (Fig. 8). At the same time, there was no diurnal cycle for particulate ammonium. Therefore, the summertime diurnal cycle of ammonia cannot be explained by the dissociation of $\mathrm{NH}_{4} \mathrm{NO}_{3}$ to $\mathrm{NH}_{3}$ and $\mathrm{HNO}_{3}$. In winter, the ammonia concentration remained very low for most of the time, mainly below $0.1 \mathrm{ppb}$. In March there was no diurnal variation, but the variation in the concentrations as a whole was strong, with a maximum concentration of about $1 \mathrm{ppb}$. From the end of April the diurnal variation in ammonia began again.

\section{Temperature dependence of ammonia concentrations}

The observed diurnal cycle of the ammonia concentration suggests that ammonia previously absorbed on the leaf surfaces of trees and vegetation during the nighttime may be re-emitted as the temperature of the leaves rises again during warm summer days. In addition, decomposition of leaves and processes within the forest soil releases ammonia. However, the simultaneous increase in VOC concentrations at the same site (Hakola et al. 2012) may indicate that biogenic ammonia sources also contribute.

Vegetation emits ammonia when exposed to air in which the ammonia concentrations are lower than the compensation point (denoted generally by $\chi_{\mathrm{s}}$ ), i.e., the ammonia partial pressure in the substomatal cavities of the plants (e.g. Farquhar et al. 1980). The reverse also occurs: if the atmospheric concentration is higher than the compensation point the plants act as a sink for ammonia. The ambient concentrations approach the compensation point when there are no additional ammonia sources or sinks (e.g. Langford and Fehsenfeld 1992). The compensation point depends on the temperature (e.g. Farquhar et al. 1980), ammonium concentration and $\mathrm{pH}$ in the plant apoplast, and these things depend on other factors such as the plant species and nitrogen supply (e.g. Schjoerring et al. 1998, Köstner et al. 2008).

The measurements discussed in the present paper are insufficient to determine the compensation point; for that measurement of fluxes would also be necessary. However, the observed temperature dependence is compared with that presented in the previous studies (Fig. 9). Lang-

Table 3. Statistical summary for the inorganic compounds measured in $\mathrm{PM}_{10}$ and $\mathrm{PM}_{25}$ with the MARGA at SMEAR II on 22 June 2010-30 April 2011. Concentrations are given in $\mu \mathrm{g} \mathrm{m}^{-3}$ at $20^{\circ} \mathrm{C}$ and $1013 \mathrm{hPa}$.

\begin{tabular}{|c|c|c|c|c|c|c|c|c|c|c|c|}
\hline & & \multicolumn{2}{|l|}{ All } & \multicolumn{2}{|c|}{ Summer } & \multicolumn{2}{|c|}{ Autumn } & \multicolumn{2}{|c|}{ Winter } & \multicolumn{2}{|c|}{ Spring } \\
\hline & & mean $\pm S D$ & $\max$ & mean $\pm S D$ & $\max$ & mean $\pm S D$ & $\max$ & mean $\pm S D$ & $\max$ & mean $\pm S D$ & $\max$ \\
\hline \multirow[t]{2}{*}{$\mathrm{Cl}^{-}$} & $\mathrm{PM}_{2.5}$ & $0.04 \pm 0.10$ & 1.08 & $0.02 \pm 0.02$ & 0.13 & $0.05 \pm 0.10$ & 0.60 & $0.02 \pm 0.07$ & 0.61 & $0.08 \pm 0.14$ & 1.08 \\
\hline & $\mathrm{PM}_{10}^{2.5}$ & $0.08 \pm 0.16$ & 1.94 & $0.05 \pm 0.10$ & 0.58 & $0.09 \pm 0.17$ & 1.17 & $0.04 \pm 0.11$ & 0.84 & $.14 \pm 0.21$ & 1.94 \\
\hline \multirow[t]{2}{*}{$\mathrm{NO}_{3}^{-}$} & $\mathrm{PM}_{2.5}$ & $0.26 \pm 0.33$ & 4.37 & $0.17 \pm 0.11$ & 0.76 & $0.31 \pm 0.38$ & 3.33 & $0.24 \pm 0.30$ & 1.88 & $0.34 \pm 0.44$ & 4.37 \\
\hline & $\mathrm{PM}_{1}$ & $0.41 \pm 0.45$ & 4.19 & $0.33 \pm 0.23$ & 1.37 & $0.38 \pm 0.53$ & 4.19 & $0.47 \pm 0.45$ & 3.03 & $0.44 \pm 0.54$ & 3.89 \\
\hline \multirow[t]{2}{*}{$\mathrm{SO}_{4}^{2-}$} & $\mathrm{PM}_{2.5}$ & $0.83 \pm 0.87$ & 8.69 & $1.42 \pm 0.96$ & 7.97 & $0.71 \pm 0.69$ & 3.70 & $0.64 \pm 0.92$ & 8.69 & $0.57 \pm 0.40$ & 2.56 \\
\hline & $\mathrm{PM}_{10}$ & $1.08 \pm 1.07$ & 10.20 & $1.34 \pm 1.02$ & 8.64 & $0.77 \pm 0.76$ & 3.91 & $1.39 \pm 1.38$ & 10.20 & $0.70 \pm 0.49$ & 3.30 \\
\hline \multirow[t]{2}{*}{$\mathrm{Na}^{+}$} & $\mathrm{PM}_{25}$ & $0.06 \pm 0.09$ & 0.89 & $0.02 \pm 0.04$ & 0.26 & $0.06 \pm 0.09$ & 0.67 & $0.07 \pm 0.09$ & 0.89 & $0.20 \pm 0.12$ & 0.72 \\
\hline & $\mathrm{PM}_{10}$ & $0.13 \pm 0.15$ & 1.13 & $0.05 \pm 0.09$ & 0.57 & $0.10 \pm 0.14$ & 1.13 & $0.19 \pm 0.15$ & 0.94 & $0.25 \pm 0.16$ & 0.91 \\
\hline \multirow[t]{2}{*}{$\mathrm{NH}_{4}^{+}$} & $\mathrm{PM}_{25}$ & $0.33 \pm 0.39$ & 3.98 & $0.60 \pm 0.45$ & 3.04 & $0.27 \pm 0.32$ & 1.85 & $0.20 \pm 0.26$ & 1.41 & $0.23 \pm 0.37$ & 3.98 \\
\hline & $\mathrm{PM}_{10}$ & $0.37 \pm 0.43$ & 4.17 & $0.55 \pm 0.47$ & 3.17 & $0.27 \pm 0.35$ & 2.07 & $0.38 \pm 0.43$ & 2.49 & $0.28 \pm 0.41$ & 4.17 \\
\hline \multirow[t]{2}{*}{$\mathrm{K}^{+}$} & $\mathrm{PM}_{2.5}$ & $0.04 \pm 0.08$ & 2.63 & $0.05 \pm 0.14$ & 2.63 & $0.04 \pm 0.05$ & 0.90 & $0.04 \pm 0.06$ & 0.58 & $0.04 \pm 0.05$ & 0.48 \\
\hline & $\mathrm{PM}_{10}$ & $0.06 \pm 0.10$ & 3.56 & $0.07 \pm 0.17$ & 3.56 & $0.05 \pm 0.06$ & 1.04 & $0.07 \pm 0.08$ & 0.78 & $0.04 \pm 0.07$ & 1.06 \\
\hline \multirow[t]{2}{*}{$\mathrm{Mg}^{2+}$} & $\mathrm{PM}_{2.5}$ & $0.02 \pm 0.03$ & 0.24 & $0.05 \pm 0.04$ & 0.24 & $0.01 \pm 0.01$ & 0.09 & $0.01 \pm 0.01$ & 0.09 & $0.02 \pm 0.01$ & 0.09 \\
\hline & $\mathrm{PM}_{10}$ & $0.04 \pm 0.06$ & 0.75 & $0.10 \pm 0.09$ & 0.75 & $0.02 \pm 0.02$ & 0.19 & $0.02 \pm 0.01$ & 0.10 & $0.02 \pm 0.01$ & 0.11 \\
\hline \multirow[t]{2}{*}{$\mathrm{Ca}^{2+}$} & $\mathrm{PM}_{2.5}$ & $0.06 \pm 0.12$ & 1.55 & $0.18 \pm 0.20$ & 1.55 & $0.01 \pm 0.01$ & 0.08 & $0.02 \pm 0.02$ & 0.25 & $0.03 \pm 0.02$ & 0.25 \\
\hline & $\mathrm{PM}_{10}$ & $0.13 \pm 0.38$ & 8.14 & $0.47 \pm 0.68$ & 8.14 & $0.02 \pm 0.03$ & 0.34 & $0.03 \pm 0.03$ & 0.28 & $0.03 \pm 0.03$ & 0.34 \\
\hline
\end{tabular}



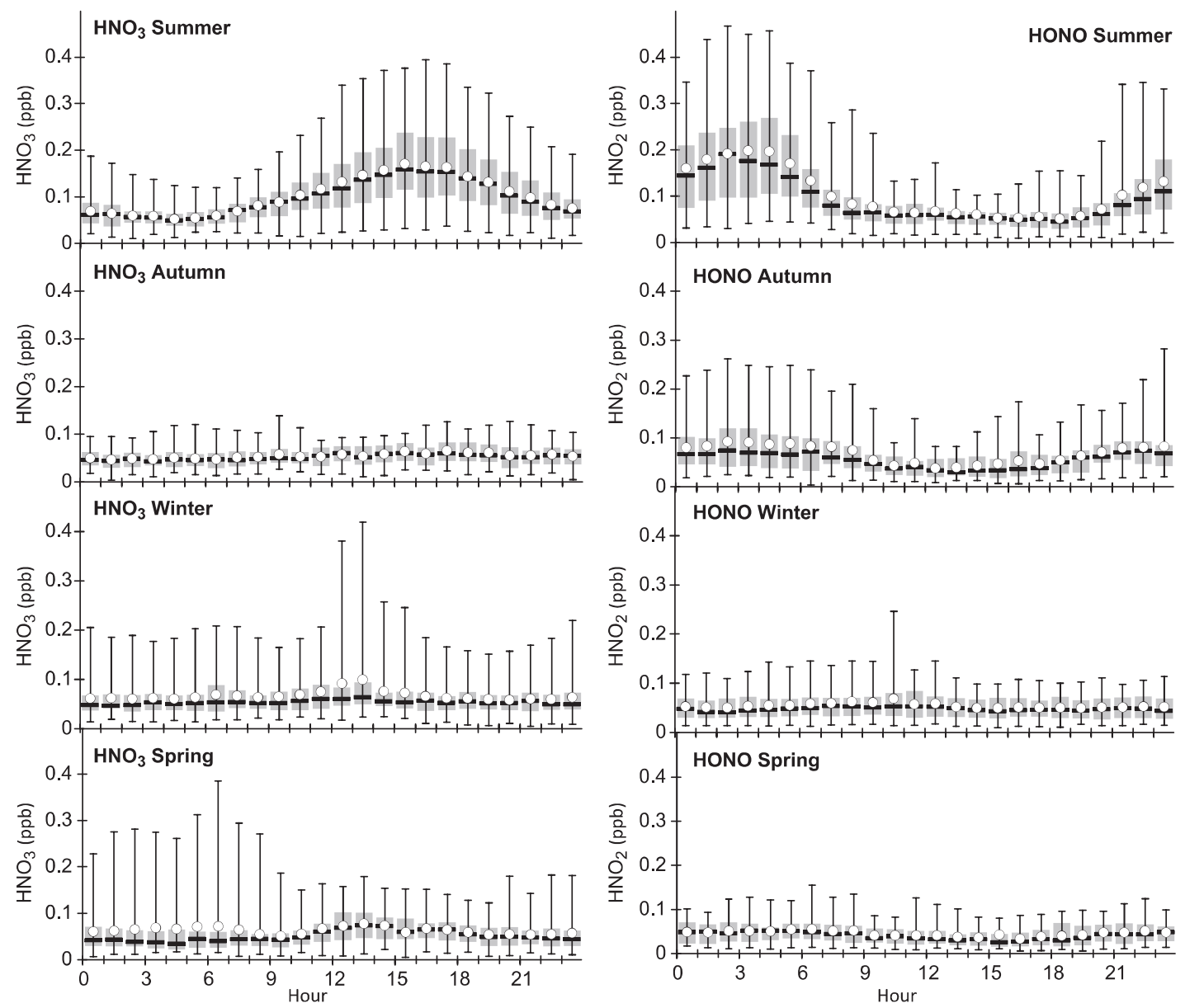

Fig. 7. Diurnal cycles of nitric and nitrous acids in the four seasons. The box represents the 25th to 75th percentile range, the bars the 90 percent range (5th and 95th percentiles), the horizontal line the median and the circle the averages of the hourly-averaged data for each hour.

ford and Fehsenfeld (1992) measured ammonia concentrations in a forest in Colorado and found that the compensation point was $0.8 \mathrm{ppb}$ at $20{ }^{\circ} \mathrm{C}$ (cf. Fig. 9). The temperature-dependent compensation point $\chi_{\mathrm{s}}$ was calculated from the formula (Husted and Schjoerring 1996, Tarnay et al. 2001):

$$
\chi_{\mathrm{s}}=\chi_{\mathrm{s}}^{*} \exp \left[-\frac{\Delta H_{\mathrm{dis}}^{0}+\Delta H_{\mathrm{vap}}^{0}}{R}\left(\frac{1}{T}-\frac{1}{T^{*}}\right)\right],
$$

where $X_{\mathrm{s}}^{*}$ is the compensation point at the temperature $T^{*}, \Delta H_{\text {dis }}{ }^{0}$ is the enthalpy of $\mathrm{NH}_{4}^{+}$dissociation $=52.21 \mathrm{~kJ} \mathrm{~mol}^{-1}, \Delta H_{\text {vap }}{ }^{0}$ is the enthalpy of vaporization $=34.18 \mathrm{~kJ} \mathrm{~mol}^{-1}, R=8.314$ $\mathrm{J} \mathrm{mol}^{-1} \mathrm{~K}^{-1}$, and $T$ is the absolute temperature (cf. Fig. 9). Another approach is to measure the compensation point of selected plant species Köstner et al. (2008) used the results of Hartmann (2005) to calculate the stomatal ammonia compensation point of Norway spruce (Picea abies) needles and used the temperature dependence presented by Nemitz et al. (2000)

$$
\chi_{\mathrm{s}}=\frac{161500}{T} \exp \left(-\frac{10380}{T}\right) \frac{\left[\mathrm{NH}_{4}^{+}\right]}{\left[\mathrm{H}^{+}\right]},
$$

where $\left[\mathrm{NH}_{4}^{+}\right]$and $\left[\mathrm{H}^{+}\right]$are the ammonium and hydrogen ion concentrations, respectively, in the apoplast of the needles. At $25^{\circ} \mathrm{C}$ the range of the compensation point was $0.11-0.27$ ppb (Köstner et al. 2008; cf. Fig. 9).

These concentrations are higher than those determined only from the needles but lower than 
the compensation point in the forest in Colorado. A probable explanation is that the measured ammonia is emitted not only by Norway spruce but also by other vegetation around the measurement site. Further studies would be needed to determine the ammonia compensation points of various species at SMEAR II.

The data presented in Fig. 9 were further used for deriving a function describing the temperature dependence of ammonia. It is not called the compensation point here, since the measurements were insufficient to determine whether the ammonia concentration was in equilibrium. An exponential function of temperature fitted to all the data yielded the function

$$
\begin{aligned}
{\left[\mathrm{NH}_{3}\right](T) } & =\left[\mathrm{NH}_{3}\right]_{0} \exp (k T) \\
& =0.077(\mathrm{ppb}) \exp \left[0.071 T\left({ }^{\circ} \mathrm{C}\right)\right] .
\end{aligned}
$$

Next, the data were grouped into relative humidity ranges, and an exponential function $\left[\mathrm{NH}_{3}\right]=\left[\mathrm{NH}_{3}\right]_{0} \exp (k T)$ was again fitted to the data (Fig. 9). The factors $k$ and $\left[\mathrm{NH}_{3}\right]_{0}$ varied almost linearly with the relative humidity, $\mathrm{RH}$ (Fig. 10). These factors were combined, yielding the function

$$
\begin{aligned}
& {\left[\mathrm{NH}_{3}\right](\mathrm{RH}, T)=} \\
& \quad=[0.000739(\mathrm{ppb}) \mathrm{RH}(\%)+00891(\mathrm{ppb})] \\
& \quad \times \exp \left[(-0.00118 \mathrm{RH}+0.164) T\left({ }^{\circ} \mathrm{C}\right)\right] .
\end{aligned}
$$

The concentrations modelled with the functions given by Eqs. 3 and 4 were plotted against the measurements (Fig. 11). The function given by Eq. 3, which takes only temperature into account, clearly agrees less with the data than the function given by Eq. 4, which depends on RH as well. Even though the coefficients of determination $\left(r^{2}=0.631\right.$ and $\left.r^{2}=0.644\right)$ are approximately the same, the function given by Eq. 4 yields concentrations much closer to the $1: 1$ line, especially at the higher concentrations. However, it is obvious from the scatter in the data that even if both $\mathrm{RH}$ and temperature are taken into account, the differences between the modelled and observed concentrations are still large, showing that ammonia concentrations depend strongly on other factors too. This parameterization needs to be quantified and verified with detailed emission measurements.

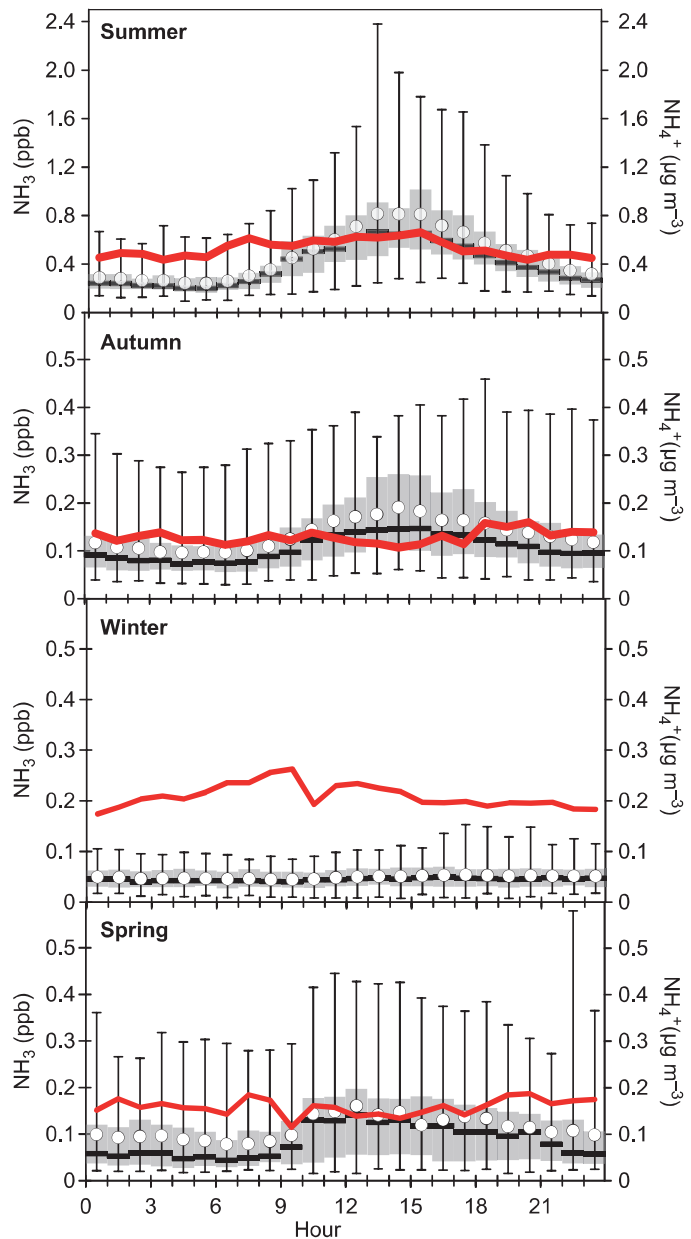

Fig. 8. Diurnal cycle of ammonia in the four seasons. The box represents the 25th to 75th percentile range, the bars the $90 \%$ range (5th and 95 th percentiles), the horizontal line the median and the circle the averages of the hourly-averaged data for each hour. The red lines present the medium ammonium concentrations $\left(\mu \mathrm{g} \mathrm{m}^{-3}\right)$ in $\mathrm{PM}_{10}$ fraction.

The temperature dependence found in this study is in agreement with earlier findings. Warm weather leads to greater ammonia volatilization (Monteny and Erisman 1998) and also increases emissions from vegetation. An increase in the temperature from 15 to $30{ }^{\circ} \mathrm{C}$ may cause a plant to switch from being a strong sink for atmospheric $\mathrm{NH}_{3}$ to being a significant $\mathrm{NH}_{3}$ source (Schoerring et al. 1998). Husted and Schoerring (1996) found that increasing the leaf temperatures of oilseed rape plants from 10 to $35^{\circ} \mathrm{C}$ caused an exponential increase in $\mathrm{NH}_{3}$ emission 

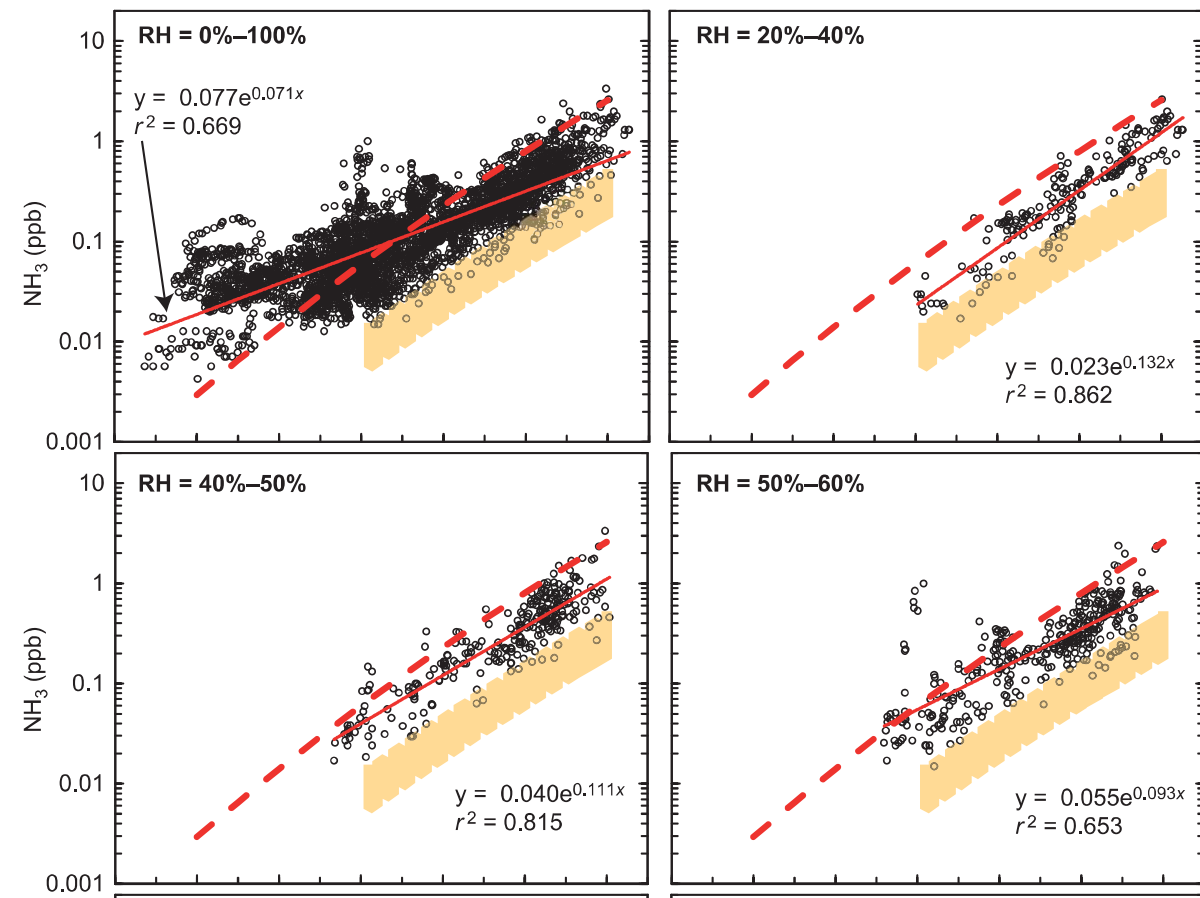

$\mathrm{RH}=50 \%-60 \%$
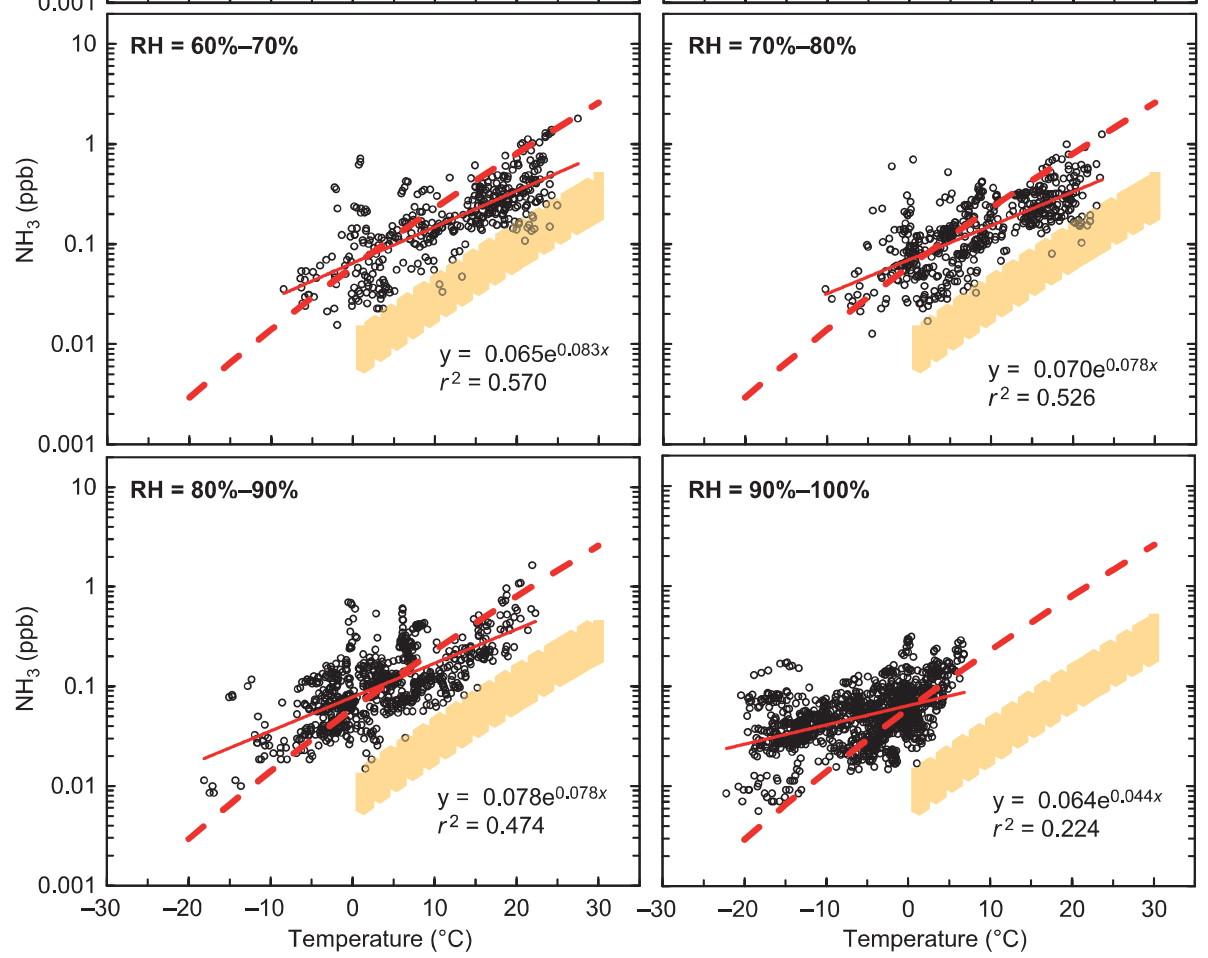

- L\&F, H\&S

H, K\&al, N\&al

Fig. 9. Ammonia concentration as a function of temperature in eight ranges of relative humidity (red, solid line; this work). The dashed, red line shows the ammonia compensation point determined from measurements in a forest in Colorado by Langford and Fehsenfeld (1992: L\&F) and by using the temperature dependence calculated with the formula presented by Husted and Schjoerring (1996: H\&S), and the yellow shaded area the range of ammonia compensation points of Norway Spruce needles determined by Hartmann (2005: H) and Köstner et al. (2008: K\&al) with the temperature dependence presented by Nemitz et al. (2000: N\&al). 

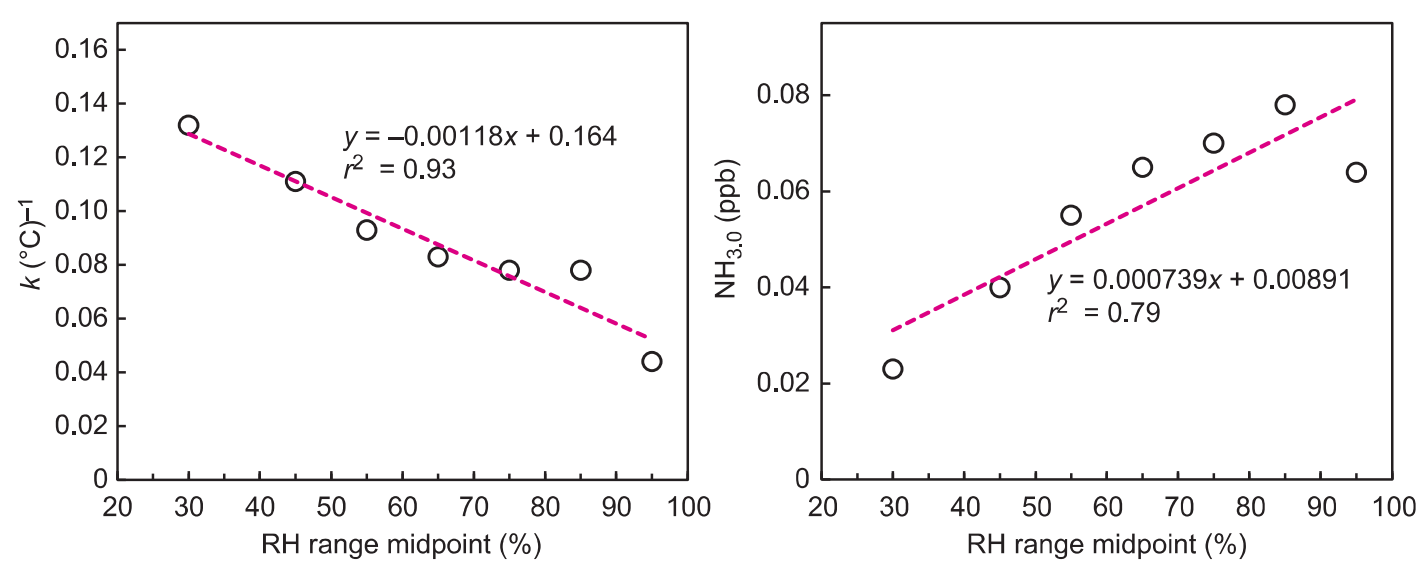

Fig. 10. Variation of the factors $k$ and $\left[\mathrm{NH}_{3}\right]_{0}$ in $\left[\mathrm{NH}_{3}\right]=\left[\mathrm{NH}_{3}\right]_{0} \exp \left(k \times T\left({ }^{\circ} \mathrm{C}\right)\right)$ and $\left[\mathrm{NH}_{3}\right]_{0}$ as a function of $\mathrm{RH}$ range midpoint, as obtained from the exponential fits in Fig. 9.
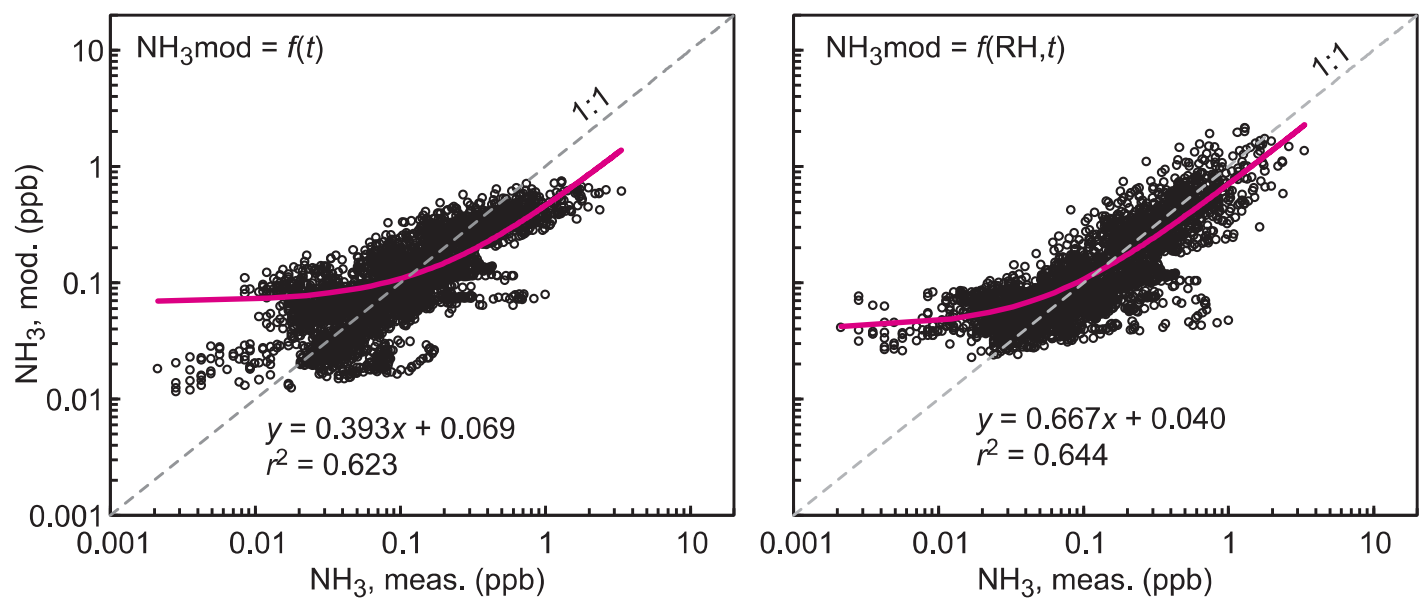

Fig. 11. Comparison of modelled and measured ammonia concentrations. In the left-hand-side panel the modelled concentrations were calculated with Eq. 3, and in the right-hand-side panel with Eq. 4. In both plots the red line is the linear regression described by the equation.

from plants exposed to low ambient $\mathrm{NH}_{3}$ concentrations.

\section{Conclusions}

In this study, we presented for the first time, concentrations of ionic compounds in particulate matter and ammonia measured with a 1-h time resolution at a Nordic background site. The results of this study suggest that the EMEP filter method could indeed be replaced with a MARGA instrument equipped with a concentration column, at least for cations. This would reduce the laboratory work, e.g. the pretreatment of filters, but it would increase the maintenance work in the field. On the other hand, there would be several benefits from using data with 1 -h time resolution instead of daily-average results, such as monitoring of diurnal profiles and their seasonal cycles and other short-term variability, which is not possible with the traditional filter methods. Gas and aerosol data with a higher time resolution could also be used for model evaluations (Schaap 2011) and for various kinds of atmospheric chemistry or aerosol studies, for example for getting detailed information on the gas-aerosol partitioning of semi-volatile species. When compared with those produced by AMS, satisfactory results were achieved for sulphate 
and ammonium, but for nitrate there was a large variation because of the different cutoff.

All the compounds measured with MARGA agreed quite well with the concentrations obtained from the analyses of the EMEP filter pack, except for nitric acid. The concentrations of $\mathrm{HNO}_{3}$ measured with MARGA were only about $50 \%$ of those found on the impregnated filter. For a better recovery of $\mathrm{HNO}_{3}$ in the MARGA system, short Teflon inlet-tubing should be used, as recommended by Rumsay et al. (2013), bearing in mind that it may also disturb the collection of particulate matter. In parallel measurements of cavity ring-down spectroscopy (CRDS) and of the MARGA instrument in Kleiner Feldberg in Germany, elevated nocturnal concentrations of $\mathrm{N}_{2} \mathrm{O}_{5}$ led to nighttime peaks in the $\mathrm{HNO}_{3}$ concentrations measured by MARGA (Phillips et al. 2013). However, in Hyytiälä we could not find any nighttime $\mathrm{HNO}_{3}$ peaks that indicated the presence of $\mathrm{N}_{2} \mathrm{O}_{5}$.

The average concentrations of all nitrogencontaining gases were highest in summer when both $\mathrm{HONO}$ and $\mathrm{HNO}_{3}$ showed diurnal cycles depending on the amount of sunlight. In summer, the HONO concentrations were clearly higher than those predicted by a ratio of HONO to $\mathrm{NO}_{x}$ concentrations in road traffic emissions alone, suggesting that soil is a source of HONO in summer. This is in line with the findings of Su et al. (2011). Ammonia also showed a clear diurnal cycle in the summer, with a maximum at noon, but during cold periods (temperature below $0{ }^{\circ} \mathrm{C}$ ) ammonia concentrations were often below the detection limit. In spring the diurnal variation of ammonia started again.

Ammonia concentrations were exponentially dependent on the prevailing temperature, in line with published temperature dependence of ammonia compensation points. The concentration was lower than that calculated from data presented from a forest in Colorado, but higher than that calculated from the compensation point of Norway spruce needles. The increase with temperature was greater during drier periods. For particulate ammonium there was no diurnal cycle, so the daily variation of ammonia was most likely caused by emissions, something that needs to be studied further.
Acknowledgements: This work was supported by the Academy of Finland as part of the Centre of Excellence program (project no. 1118615).

\section{References}

Aan de Brugh J.M.J., Henzing J.S., Schaap M., Morgan W.T., van Heerwaarden C.C., Weijers E.P., Coe H. \& Krol M.C. 2012. Modelling the partitioning of ammonium nitrate in the convective boundary layer. Atmos. Chem. Phys. 12: 3005-3023.

Bouwman A.F., Lee D.S., Asman W.A.H., Dentener F.J., Van Der Hoek K.W. \& Olivier J.G.J. 1997. A global high-resolution emission inventory for ammonia. Global Biogeochem. Cycles 11: 561-587.

Butterbach-Bahl K., Nemitz E., Zaehle S., Billen B., Boeckx P., Erisman J.W., Garnier J., Upstill-Goddard R., Kreuzer M., Oenema M., Reis S., Schaap M., Simpson D., de Vries W., Winiwarter W. \& Sutton M.A. 2011. Nitrogen as a threat to the European greenhouse balance In: Sutton M.A., Howard C., Erisman J.W., Billen G. Bleeker A., Grennfelt P., van Grinsven H. \& Grizzetti B. (eds.), The European nitrogen assessment: sources, effects and policy perspectives, Cambridge University Press, Cambridge, pp. 434-462.

Cape J.N. 2009. Operation of EMEP 'supersites' in the United Kingdom. Annual report for 2007. Avialable at http://nora.nerc.ac.uk/8660/2/EMEP_supersite_ report_2007N008660CR.pdf.

Draxler R.R. \& Rolph G.D. 2013. HYSPLIT (HYbrid Single-Particle Lagrangian Integrated Trajectory) Model. NOAA Air Resources Laboratory, College Park, MD [Available at http://www.arl.noaa.gov/HYSPLIT.php].

Drewnick F., Hings S.S., DeCarlo P.F., Jayne J.T., Gonin M., Fuhrer K., Weimer S., Jimenez J.L., Demerjian K.L. Borrmann S. \& Worsnop D.R. 2005. A new Time-ofFlight Aerosol Mass Spectrometer (ToF-AMS) - instrument description and first field deployment. Aerosol Sci. Technol. 39: 637-658.

EMEP 2001. EMEP manual for sampling and chemical analysis. EMEP/CCC-Report 1/95, Rev. 2001, Norwegian Institute for Air Research, Kjeller. [Available at http:// www.nilu.no/projects/ccc/manual/index.html].

Farquhar G.D., Firth P.M., Wetselaar R. \& Weir B. 1980. On the gaseous exchange of ammonia between leaves and the environment. Determination of the ammonia compensation point. Plant Physiology 66: 710-714.

Ferm M. \& Hellsten S. 2012. Trends in atmospheric ammonia and particulate ammonium concentrations in Sweden and its causes. Atmos. Environ. 60: 30-39.

Finlayson-Pitts B.J. \& Pitts J.N. 2000. Chemistry of the upper and lower atmosphere: theory, experiments and application. Academic Press, San Diego, CA.

Hakola H., Hellén H., Hemmilä M., Rinne J. \& Kulmala M. 2012. In situ measurements of volatile organic compounds in a boreal forest. Atmos. Chem. Phys. 12: 11665-11678.

Hari P. \& Kulmala M. 2005. Station for measuring ecosys- 
tem-atmosphere relations (SMEAR II). Boreal Env. Res. 10: $315-322$.

Hartmann A. 2005. Erarbeitung von Methoden zur Extraktion der Extrazellulärflüssigkeit von Fichtennadeln für die Bestimmung des Ammoniak-Kompensationspunktes. Diploma Thesis, Interdisziplinäres Ökologisches Zentrum, TU Bergakademie Freiberg.

Husted S. \& Schjoerring J.K. 1996. Ammonia flux between oilseed rape plants and the atmosphere in response to changes in leaf temperature, light intensity, and air humidity - interactions with leaf conductance and apoplastic $\mathrm{NH}_{4}^{+}$and $\mathrm{H}^{+}$concentrations. Plant Physiology 112: 67-74.

Jayne J.T., Leard D.C., Zhang X., Davidovits P., Smith K.A., Kolb C.E. \& Worsnop D.R. 2000. Development of an aerosol mass spectrometer for size and composition analysis of submicron particles. Aerosol Sci. Technol. 33: 49-70.

Jimenez J.L., Jayne J.T., Shi Q., Kolb C.E., Worsnop D.R., Yourshaw I., Seinfeld J.H., Flagan R.C., Zhang X., Smith K.A., Morris J.W. \& Davidovits P. 2003. Ambient aerosol sampling using the Aerodyne Aerosol Mass Spectrometer. J. Geophys Res. 108(D7), 8425, doi:10.1029/2001JD001213.

Khlystov A., Wyers G.P. \& Slanina J. 1995. The steam-jet aerosol collector. Atmos. Environ. 29: 2229-2234.

Kirkby J., Curtius J., Almeida J., Dunne E., Duplissy J., Ehrhart S., Franchin A., Gagné S., Ickes L., Kürten A., Kupc A., Metzger A., Riccobono F., Rondo L., Schobesberger S., Tsagkogeorgas G., Wimmer D., Amorim A., Bianchi F., Breitenlechner M., David A., Dommen J., Downard A., Ehn M., Flagan R.C., Haider S., Hansel A., Hauser D., Jud W., Junninen H., Kreissl F., Kvashin A., Laaksonen A., Lehtipalo K., Lima J., Lovejoy E.R., Makhmutov V., Mathot S., Mikkilä J., Minginette P., Mogo S., Nieminen T., Onnela A., Pereira P., Petäjä T., Schnitzhofer R., Seinfeld J.H., Sipilä M., Stozhkov Y., Stratmann F., Tomé A., Vanhanen J., Viisanen Y., Vrtala A., Wagner P.E., Walther H., Weingartner E., Wex H., Winkler P.M., Carslaw K.S., Worsnop D.R., Baltensperger U. \& Kulmala M. 2011. Role of sulphuric acid, ammonia and galactic cosmic rays in atmospheric aerosol nucleation. Nature 476: 429-433.

Köstner B., Matyssek R., Heilmeier H., Clausnitzer F., Nunn A.J. \& Wieser G. 2007. Sap flow measurements as a basis for assessing trace-gas exchange of trees. Flora 203: 14-33.

Kulmala M. \& Petäjä T. 2011. Soil nitrites influence atmospheric chemistry. Science 333: 1586-1587.

Kulmala M., Pirjola L. \& Mäkelä J.M. 2000. Stable sulphate clusters as a source of new atmospheric particles. Nature 404: 66-69.

Langford A.O. \& Fehsenfeld F.C. 1992. Natural vegetation as a source or sink for atmospheric ammonia: a case study. Science 255: 581-583.

Liu P.S.K., Deng R., Smith K.A., Williams L.R., Jayne J.T., Canagaratna M.R., Moore K., Onasch T.B., Worsnop D.R. \& Deshler T. 2007. Transmission efficiency of an aerodynamic focusing lens system: comparison of model calculations and laboratory measurements for the Aero- dyne Aerosol Mass spectrometer. Aerosol Sci. Technol. 41: 721-733.

Makkonen U., Virkkula A., Mäntykenttä J., Hakola H., Keronen P., Vakkari V. \& Aalto P.P. 2012. Semi-continuous gas and inorganic aerosol measurements at a Finnish urban site: comparisons with filters, nitrogen in aerosol and gas phases, and aerosol acidity. Atmos. Chem. Phys. 12: 5617-5631.

Monteny G.J. \& Erisman J.W. 1998. Ammonia emission from dairy cow buildings: a review of measurement techniques, influencing factors and possibilities for reduction. Netherlands Journal of Agricultural Science 46: 225-247.

Neuman J.A., Huey L.G., Ryerson T.B. \& Fahey D.W. 1999. Study of inlet materials for sampling atmospheric nitric acid. Environ. Sci. Technol. 33: 1133-1136.

Nemitz E., Sutton M.A., Schjoerring J.K., Husted S. \& Wyers G.P. 2000. Resistance modelling of ammonia exchange over oilseed rape. Agric. For. Meteorol. 105: 405-425.

Park J. \& Lin M.C. 1997. A mass spectrometric study of the $\mathrm{NH}_{2}+\mathrm{NO}_{2}$ reaction. J. Phys. Chem. A 101: 2643-2647.

Petäjä T., Mauldin R.L.III, Kosciuch E., McGrath J., Nieminen T., Paasonen P., Boy M., Adamov A., Kotiaho T. \& Kulmala M. 2009. Sulfuric acid and $\mathrm{OH}$ concentrations in a boreal forest site. Atmos. Chem. Phys. 9: 7435-7448.

Phillips G.J., Makkonen U., Schuster G., Sobanski N., Hakola H. \& Crowley J.N. 2013. The detection of nocturnal $\mathrm{N}_{2} \mathrm{O}_{5}$ as $\mathrm{HNO}_{3}$ by alkali- and aqueous-denuder techniques. Atmos. Meas. Tech. 6: 231-237.

Rolph G.D. 2013. Real-time Environmental Applications and Display sYstem (READY). NOAAAir Resources Laboratory, College Park, MD. [Available at http://www.ready. noaa.gov].

Rumsey I.C., Cowen K.A., Walker J.T., Kelly T.J., Hanft E.A., Mishoe K., Rogers C., Proost R., Beachley G.M., Lear G., Frelink T. \& Otjes R.P. 2013. An assessment of the performance of the Monitor for AeRosols and GAses in ambient air (MARGA): a semi-continuous method for soluble compounds. Atmos. Chem. Phys. Discuss. 13: 25067-25124.

Ruoho-Airola T., Leppänen S. \& Makkonen U. 2010. Changes in the concentration of reduced nitrogen in the air in Finland between 1990 and 2007. Boreal Env. Res. 15: 427-436.

Schaap M., Otjes R.P. \& Weijers E.P. 2011. Illustrating the benefit of using hourly monitoring data on secondary inorganic aerosol and its precursors for model evaluation. Atmos. Chem. Phys. 11: 11041-11053.

Schjoerring J.K., Husted S. \& Mattsson M. 1998. Physiological parameters controlling plant-atmosphere ammonia exchange. Atmos. Environ. 32: 491-498.

Slanina J., ten Brink H.M., Otjes R.P., Even A., Jongejan P., Khlystov S., Waijers-Ijpelaan A., Hu M. \& Lu Y. 2001. The continuous analysis of nitrate and ammonium in aerosols by the steam jet aerosol collector (SJAC): extension and validation of the methodology. Atmos. Environ. 35: 2319-2330.

Su H., Cheng Y., Oswald R., Behrendt T., Trebs I., Meixner F., Andreae M., Cheng P., Zhang Y. \& Pöschl U. 2011. Soil nitrite as a source of atmospheric $\mathrm{HONO}$ and $\mathrm{OH}$ 
radicals. Science 333: 1616-1618.

Sutton M.A., Howard C., Erisman J.W., Billen G., Bleeker A., Grennfelt P., van Grinsven H. \& Grizzetti B. 2011a. The European nitrogen assessment. Cambridge University Press, Cambridge.

Sutton M.A., Nemitz E., Skiba U.M., Beier C., ButterbachBahl K., Cellier P., de Vries W., Erisman J.W., Reis S., Bleeker A., Bergamaschi P., Calanca P.L., Dalgaard T., Duyzer J., Gundersen P., Hensen A., Kros J., Leip A., Olesen J.E., Owen S., Rees R.M., Sheppard L.J., Smith P., Zechmeister-Boltenstern S., Soussana J.F., Theobald M.R., Twigg M., van Oijen M., Veldkamp T., Vesala T., Winiwarter W., Carter M.S., Dragosits U., Flechard C., Helfter C., Kitzler B., Rahn K.H., Reinds G.J. \& Schleppi P. with contributions from the NitroEurope community 2011b. The nitrogen cycle and its influence on the European greenhouse gas balance. Centre for Ecology and Hydrology.

Tarnay L., Gertler A.W., Blank R.R. \& Taylor G.E.Jr. 2001 Preliminary measurements of summer nitric acid and ammonia concentrations in the Lake Tahoe Basin airshed: Implications for dry deposition of atmospheric nitrogen. Environ. Pollut. 113: 145-153.

ten Brink H.M., Otjes R., Jongejan P. \& Slanina S. 2007. An instrument for semi-continuous monitoring of the sizedistribution of nitrate, ammonium, sulphate and chloride in aerosol. Atmos. Environ. 41: 2768-2779.

Williams J., Crowley J., Fischer H., Harder H., Martinez M., Petäjä T., Rinne J., Bäck J., Boy M., Dal Maso M., Hakala J., Kajos M., Keronen P., Rantala P., Aalto J. Aaltonen H., Paatero J., Vesala T., Hakola H., Levula J., Pohja T., Herrmann F., Auld J., Mesarchaki E., Song W., Yassaa N., Nölscher A., Johnson A.M., Custer T., Sinha V., Thieser J., Pouvesle N., Taraborrelli D., Tang M.J. Bozem H., Hosaynali-Beygi Z., Axinte R., Oswald R. Novelli A., Kubistin D., Hens K., Javed U., Trawny K. Breitenberger C., Hidalgo P.J., Ebben C.J., Geiger F.M. Corrigan A.L., Russell L.M., Ouwersloot H.G., VilàGuerau de Arellano J., Ganzeveld L., Vogel A., Beck M., Bayerle A., Kampf C.J., Bertelmann M., Köllner F. Hoffmann T., Valverde J., González D., Riekkola M.-L., Kulmala M. \& Lelieveld J. 2011. The summertime Boreal forest field measurement intensive HUMPPACOPEC-2010: an overview of meteorological and chemical influences. Atmos. Chem. Phys. 11: 10599-10618.

Zbieranowski A.L. \& Aherne J. 2012. Spatial and temporal concentration of ambient atmospheric ammonia in southern Ontario, Canada. Atmos. Environ. 62: 441-450. 

Atmos. Chem. Phys., 18, 6367-6380, 2018

https://doi.org/10.5194/acp-18-6367-2018

(c) Author(s) 2018. This work is distributed under

the Creative Commons Attribution 4.0 License.

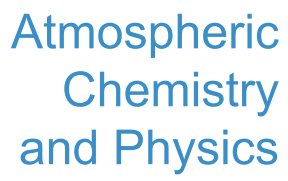

(c) (P)

\title{
Amines in boreal forest air at SMEAR II station in Finland
}

\author{
Marja Hemmilä $^{1}$, Heidi Hellén ${ }^{1}$, Aki Virkkula ${ }^{1,2}$, Ulla Makkonen ${ }^{1}$, Arnaud P. Praplan ${ }^{1}$, Jenni Kontkanen $^{2}$, \\ Lauri Ahonen $^{2}$, Markku Kulmala ${ }^{2}$, and Hannele Hakola ${ }^{1}$ \\ ${ }^{1}$ Finnish Meteorological Institute, P.O. Box 503, 00101 Helsinki, Finland \\ ${ }^{2}$ Institute for Atmospheric and Earth System Research/Physics, Faculty of Science, University of Helsinki, \\ P.O. Box 64, 00014 Helsinki, Finland
}

Correspondence: Marja Hemmilä (marja.hemmila@fmi.fi)

Received: 13 October 2017 - Discussion started: 17 October 2017

Revised: 19 March 2018 - Accepted: 20 March 2018 - Published: 4 May 2018

\begin{abstract}
We measured amines in boreal forest air in Finland both in gas and particle phases with $1 \mathrm{~h}$ time resolution using an online ion chromatograph (instrument for Measuring AeRosols and Gases in Ambient Air - MARGA) connected to an electrospray ionization quadrupole mass spectrometer (MS). The developed MARGA-MS method was able to separate and detect seven different amines: monomethylamine (MMA), dimethylamine (DMA), trimethylamine (TMA), ethylamine (EA), diethylamine (DEA), propylamine (PA), and butylamine (BA). The detection limits of the method for amines were low $\left(0.2-3.1 \mathrm{ng} \mathrm{m}^{-3}\right)$, the accuracy of ICMS analysis was $11-37 \%$, and the precision $10-15 \%$. The proper measurements in the boreal forest covered about 8 weeks between March and December 2015. The amines were found to be an inhomogeneous group of compounds, showing different seasonal and diurnal variability. Total MMA (MMA(tot)) peaked together with the sum of ammonia and ammonium ions already in March. In March, monthly means for MMA were $<2.4$ and $6.8 \pm 9.1 \mathrm{ng} \mathrm{m}^{-3}$ in gas and aerosol phases, respectively, and for $\mathrm{NH}_{3}$ and $\mathrm{NH}_{4}^{+}$these were $52 \pm 16$ and $425 \pm 371 \mathrm{ng} \mathrm{m}^{-3}$, respectively. Monthly medians in March for MMA(tot), $\mathrm{NH}_{3}$, and $\mathrm{NH}_{4}^{+}$were $<2.4$, 19 and $90 \mathrm{ng} \mathrm{m}^{-3}$, respectively. DMA(tot) and TMA(tot) had summer maxima indicating biogenic sources. We observed diurnal variation for DMA(tot) but not for TMA(tot). The highest concentrations of these compounds were measured in July. Then, monthly means for DMA were $<3.1$ and $8.4 \pm 3.1 \mathrm{ng} \mathrm{m}^{-3}$ in gas and aerosol phases, respectively, and for TMA these were $0.4 \pm 0.1$ and $1.8 \pm 0.5 \mathrm{ng} \mathrm{m}^{-3}$. Monthly medians in July for DMA were below the detection limit (DL) and $4.9 \mathrm{ng} \mathrm{m}^{-3}$ in gas and aerosol phases, respectively, and for TMA these were 0.4 and $1.4 \mathrm{ng} \mathrm{m}^{-3}$.
\end{abstract}

When relative humidity of air was $>90 \%$, gas-phase DMA correlated well with 1.1-2 $\mathrm{nm}$ particle number concentration $\left(R^{2}=0.63\right)$ suggesting that it participates in atmospheric clustering. EA concentrations were low all the time. Its July means were $<0.36$ and $0.4 \pm 0.4 \mathrm{ng} \mathrm{m}^{-3}$ in gas and aerosol phases, respectively, but individual concentration data correlated well with monoterpene concentrations in July. Monthly means of PA and BA were below detection limits at all times.

\section{Introduction}

In atmospheric chemistry and secondary aerosol production, bases are crucial since they can neutralize acids and therefore accelerate several processes, e.g., subsequent growth of newly born aerosol particles (Lehtipalo et al., 2016). Amines are gaseous bases, whose general formula is $\mathrm{RNH}_{2}, \mathrm{R}_{2} \mathrm{NH}$, or $\mathrm{R}_{3} \mathrm{~N}$. Due to their effective participation in neutralization, it is hard to detect their real atmospheric concentrations. Globally, the main known anthropogenic amine emissions are from animal husbandry, industry, and compost processes, and the natural sources of amines are assumed to be ocean, biomass burning, vegetation, and soil (Ge et al., 2011). It has been shown that amines affect hydroxyl radical $(\mathrm{OH})$ reactivity and therefore all atmospheric chemistry (Hellén et al., 2014; Kieloaho et al., 2013).

Models based on quantum chemistry data have shown that amines could participate in new particle formation (NPF) with sulfuric acid even at very low mixing ratios (Kurtén et al., 2008; Paasonen et al., 2012), and also laboratory experiments have proved formation of aminium salts when amines react with nitric or sulfuric acid (Murphy et al., 2007). In ad- 
dition, the recent experiments at the CLOUD chamber show that even at minute concentrations of dimethylamine (DMA) new particles with sulfuric acid are produced (Almeida et al., 2013; Kürten et al., 2016). Atmospheric aerosols affect the climate, because they can act as cloud condensation nuclei (IPCC, 2013). They also scatter and absorb solar radiation.

Ambient concentrations of gas-phase amines have been measured earlier using different methods: samples have been collected in phosphoric-acid-impregnated fiberglass filters (Kieloaho et al., 2013), solid-phase micro-extraction fiber (SPME; Parshintsev et al., 2015), and ion exchange resin (Dawson et al., 2014), and they have also been percolated through an acidic solution (Akyüz, 2007). Samples have been analyzed later in the laboratory with various chromatographic techniques, such as gas chromatography coupled to mass spectrometry (GC-MS) (Akyüz, 2007; Parshintsev et al., 2015), ion chromatography (IC) (Dawson et al., 2014), and high-performance liquid chromatography coupled to mass spectrometry (HPLC-MS) (Kieloaho et al., 2013). The abovementioned techniques have various shortcomings: quantitation based on collection onto fibers is problematic, collecting in filters requires long sampling times (usually several days), and percolating in acidic solutions requires intensive sample pretreatment. Dawson et al. (2014) used weak cation exchange resin as a substrate for collection of gas-phase ammonia and amines. The method minimizes sample losses on walls during sampling and has quite short sampling times (less than an hour), but the detection limits remain too high for the boreal forest environment.

In addition, novel in situ methods for measuring ambient air gas-phase amines have been developed, usually based on mass-spectrometric detection: chemical ionization mass spectrometry (CIMS), (Sellegri et al., 2005; You et al., 2014), ambient pressure proton transfer mass spectrometry (AmPMS) (Hanson et al., 2011; Freshour et al., 2014), chemical ionization atmospheric pressure interface time-of-flight mass spectrometry (CI-APi-TOF) (Kulmala et al., 2013; Sipilä et al., 2015; Kürten et al., 2016), and TOF-CIMS (Zheng et al., 2015). These in situ techniques have short time resolution and the limits of detections are small. However, these methods cannot separate amines with same masses (e.g., DMA and EA) and identification of the measured compounds remains uncertain. Chang et al. (2003) used high-efficiency planar diffusion scrubber IC (HEDS-IC) to successfully separate amines with identical masses.

Aerosol-phase amines have been sampled onto filters and analyzed later in the laboratory with similar techniques: LC-MS (Ruiz-Jiménez et al., 2012), GC-MS (Huang et al., 2014), and IC (Huang et al., 2014; van Pinxteren et al., 2015). With these methods, sampling time was long (24-133 h) and biases may be introduced due to transport and pretreatment of samples. VandenBoer et al. (2011) measured amine concentrations both in gas and particle phase with an ambient ion monitor - IC (AIM-IC). This method had $60 \mathrm{~min}$ sampling time and relatively low detection limits $\left(5-9 \mathrm{ng} \mathrm{m}^{-3}\right)$. How- ever, it could not separate TMA and DEA from each other. Also, because in atmospheric samples ammonia/ammonium can be present in concentrations several orders of magnitude higher than amines, in this method they can impede detection of some amines (e.g., MMA and EA).

These methods have been utilized in short campaigns from a couple of days to a couple of weeks. Only Kieloaho et al. (2013) measured for a longer period, but their sampling time was long (24-72 h). Most of the studies discussed previously were made in urban or suburban areas, and only a few measurements (Sellegri et al., 2005; Kieloaho et al., 2013; Kulmala et al., 2013; Sipilä et al., 2015) were made in a boreal forest. In these studies, the observed alkylamine concentrations ranged from below the detection limit to $\sim 150 \mathrm{ppt}_{\mathrm{v}}$, depending on the sampling time and the analysis method used.

Here, we present the in situ method developed for atmospheric amine measurements in this study, using an online ion chromatography instrument for Measuring AeRosols and Gases in Ambient air, coupled with mass spectrometer (MARGA-MS). The method was used in the boreal forest, where amines are expected to affect secondary aerosol formation even at extremely low concentrations (Kurtén et al., 2008; Paasonen et al., 2012; Almeida et al., 2013). We report seasonal and diurnal variations of amines in boreal forest air and their partitioning between gas and aerosol phases. A time series of diurnal observations and linkages to known boreal biogenic processes is discussed for several amines. Our investigation is the first long-term survey of sources and phase distribution of amines at the sub-pptv level in a remote boreal forest environment. In this study, we use supporting physical measurements to initiate a better understanding of this entire class of compounds relative to what we already know about ammonia.

\section{Experimental}

We measured amine and ammonia concentrations in 2015 from March to May (spring), July to August (summer), and November to December (early winter) with $1 \mathrm{~h}$ time resolution. However, due to instrumental problems, good-quality data were captured for a total of only about 8 weeks.

\subsection{Measurement site}

Measurements were performed in a Scots pine forest at the SMEAR II station (Station for Measuring Forest Ecosystem-Atmosphere Relations) in Hyytiälä, southern Finland ( $61^{\circ} 51^{\prime} \mathrm{N}, 24^{\circ} 17^{\prime} \mathrm{E}, 180 \mathrm{~m}$ a.s.l.; Hari and Kulmala, 2005,; Fig. S1 in the Supplement). The largest nearby city is Tampere, situated $60 \mathrm{~km}$ southwest from the station with approximately 222000 inhabitants in the city itself (although with 364000 in the wider metropolitan area). The instrument was located in a container about $4 \mathrm{~m}$ outside the forest in a 
small opening. In addition to pines, also small spruces (Picea abies) grow nearby. The forest was planted about 50 years ago and its current tree height is about $19 \mathrm{~m}$.

\subsection{Meteorological conditions}

Meteorological quantities were obtained from the SmartSmear AVAA portal (Junninen et al., 2009). SmartSmear is the data portal for visualization and download of continuous atmospheric, flux, soil, tree, physiological, and water quality measurements at SMEAR research stations of the University of Helsinki. Table S1 in the Supplement shows the meteorological conditions during measurement periods.

\subsection{Measurement methods}

\subsubsection{MARGA-MS}

We used the MARGA instrument (Metrohm-Applikon, Schiedam, the Netherlands) (ten Brink et al., 2007) for sampling and separating amines. MARGA is an online IC connected to a sampling system. In addition, this system was connected to an electrospray ionization (ESI) quadrupole MS (Shimadzu LCMS-2020; Shimadzu Corporation, Kyoto, Japan) to improve sensitivity of amine measurements (see Table S2 for MS settings). The MARGA instrument earlier used for measuring anions and cations in Helsinki and Hyytiälä is described in more detailed in earlier papers (Makkonen et al., 2012, 2014).

Ambient air was taken through a $\mathrm{PM}_{10}$ cyclone (URG 1032, Teflon coated) and polyethylene tubing (ID $0.5^{\prime \prime}$, length $\sim 1 \mathrm{~m}$ ) with a flow rate of $16.7 \mathrm{~L} \mathrm{~min}^{-1}$. After passing the inlet, sample air entered to a wet rotating denuder (WRD), where the gases diffused into the absorption solution (10 ppm hydrogen peroxide). Particles passed through the WRD and entered the steam jet aerosol collector (SJAC), where they were collected in a supersaturated environment (in $10 \mathrm{ppm}$ hydrogen peroxide). During each hour, liquid samples from the WRD and SJAC were collected in the syringes $(25 \mathrm{~mL})$, mixed with the internal standard $(\mathrm{LiBr}$ and deuterated diethyl- $\mathrm{d}_{10}$-amine) and injected to the cation ion chromatograph. The two sets of syringes worked in tandem, so that when a set of samples was collected, the previous ones were injected. In the cation chromatograph, $3.2 \mathrm{mmol} \mathrm{L}^{-1}$ oxalic acid (Merck, Darmstadt, Germany) solution was used as an eluent (constant flow $0.7 \mathrm{~mL} \mathrm{~min}^{-1}$ ). To get the detection limits lower, we used a concentration column (Metrosep C PCC $1 \mathrm{VHC} / 4.0)$ before the analytical column (Metrosep C4-100/4.0, $100 \mathrm{~mm} \times 4.0 \mathrm{~mm}$ ID, stationary phase silica gel with carboxyl groups, particle size $5 \mu \mathrm{m}$ ). After passing the cation column and the conductivity detector, samples were guided to the ESI needle of the mass spectrometer without any additional solvent. All solutions used were made with ultrapure water (Milli-Q, resistivity $\geq 18 \mathrm{M} \Omega \mathrm{cm}$ )
Detection limits (DLs) for MARGA-MS were calculated from signal-to-noise ratios $(3: 1)$ for most of the compounds and they were similar in gas and aerosol phases, because their blank values were so small (Table 1 in Sect. 3.1). However, DLs for DMA and TMA were calculated from blank values (3 times the standard deviations of blank values) and the DLs were different for gas- and aerosol-phase measurements.

Deuterated diethyl-d $\mathrm{d}_{10}$-amine (DEA 10 , Sigma-Aldrich: Isotec $^{\mathrm{TM}}$; Sigma-Aldrich, St. Louis, MO, USA) was used as an internal standard (ISTD) for all amines. DEA 10 was used because it behaved same way in IC separation but had different mass than studied amines. A total of $50.0 \mu \mathrm{L}$ of $\mathrm{DEA}_{10}$ was added to the MARGAs ISTD solution bottle (LiBr). After the ion chromatograph, the ISTD mixed with the sample entered the MS detection. DEA $_{10}$ was used to correct for possible losses to instrumentation and correct changes of MS response. A three-point external calibration was used for all measured alkyl amines (concentration levels 10, 50, and $300 \mathrm{ng} \mathrm{m}^{-3}$ ). The system was calibrated every 2 weeks in the field, by stopping the air flow of the MARGA and directing standard solutions to the sample syringe pumps, before analysis by IC separation and MS detection. Ammonia $\left(\mathrm{NH}_{3}\right)$ and ammonium $\left(\mathrm{NH}_{4}^{+}\right.$) (the sum of them referred to as $\mathrm{NH}_{x}$ ) were also measured with MARGA at the same time with the method described in Makkonen et al. (2012, 2014), except we used oxalic acid solution for eluent. For $\mathrm{NH}_{x}$ measurements, only a conductivity detector was used and the internal standard was lithium bromide (Acros Organics, New Jersey, USA). Instrumental blank values for MARGA-MS were measured every at least every other month with MARGAs blank mode: the sample airflow was stopped, and the analysis cycle was running for $6 \mathrm{~h}$ without sampling.

In calculations, the values under DLs were taken into account as $0.5 \times \mathrm{DL}$. In the figures, we used a moving average for DMA, because every other measured DMA concentration was a little higher than the in-between one. The system used different syringes for sample collection every other hour, and the reasons for differences are expected to be losses or contamination in the syringes. Further causes for these minor differences were not found.

\subsubsection{Aerosol measurements}

To study the role of amines in atmospheric particle formation, particle number concentration measurements were utilized. The particle number size distribution between 3 and $1000 \mathrm{~nm}$ was measured with a twin differential mobility particle sizer (DMPS) system (Aalto et al., 2001). From these measurements, the particle concentration between 3 and $25 \mathrm{~nm}\left(N_{3-25 \mathrm{~nm}}\right)$, referred to as the nucleation mode, and the total particle concentration between 3 and $1000 \mathrm{~nm}$ ( $\left.N_{\text {tot }}\right)$ were obtained. In addition, the concentrations of sub$3 \mathrm{~nm}$ particles were measured with an Airmodus particle size magnifier (PSM A11; Vanhanen et al., 2011). The PSM is a mixing-type condensation particle counter in which particles 
Table 1. DLs of different amines, ammonia, and ammonium. Conversions from $\mathrm{ng} \mathrm{m}^{-3}$ to $\mathrm{ppt}_{\mathrm{v}}$ have been made using the conversion factor $\operatorname{ppt}_{\mathrm{v}}=c\left(\mathrm{ng} \mathrm{m}^{-3}\right):(0.0409 \times(\mathrm{MW}))$ by Finlayson-Pitts and Pitts (2000), with MW the molar mass of the amine, ammonia, or ammonium. The precision for IC-MS analysis was defined by calculating standard deviations of liquid $200 \mathrm{ng} \mathrm{m}^{-3}$ standard measured six times in a row. In the data series, there were both gas and particle side measurements. The accuracy for IC-MS analysis was calculated by subtracting the averages of the data series described earlier from the expected values, dividing those by the expected values, and multiplying them by $100 \%$.

\begin{tabular}{lrrrr}
\hline Amine & $\begin{array}{r}\mathrm{DL} \\
\left(\mathrm{ng} \mathrm{m}^{-3}\right)\end{array}$ & $\begin{array}{r}\mathrm{DL} \\
\left(\mathrm{ppt}_{\mathrm{v}}\right)\end{array}$ & $\begin{array}{r}\text { Precision } \\
(\%)\end{array}$ & $\begin{array}{r}\text { Accuracy } \\
(\%)\end{array}$ \\
\hline MMA, both gas and aerosol & 2.4 & 1.9 & 10 & 24 \\
\hline DMA, & 3.1 & 1.7 & 11 & 31 \\
(March to August) gas aerosols & 1.1 & 0.20 & & \\
(November to December) gas aerosols & 0.37 & & & \\
\hline TMA, gas aerosols & 0.76 & & 14 & 11 \\
& 0.2 & 0.1 & 11 & 16 \\
\hline EA, both gas and aerosol & 0.5 & & 15 & 37 \\
\hline DEA, both gas and aerosol & 0.36 & 0.19 & 11 & 21 \\
\hline PA, both gas and aerosol & 0.24 & 0.08 & 12 & 14 \\
\hline BA, both gas and aerosol & 0.31 & 0.13 & & \\
\hline $\mathrm{NH}_{3}$, gas & 0.26 & 0.09 & & \\
NH ${ }_{4}^{+}$, aerosol & 11.4 & 16.4 & & 11 \\
\hline
\end{tabular}

are first grown to $90 \mathrm{~nm}$ size by condensation of diethylene glycol, after which butanol is used to grow them to detectable sizes. The cut-off size of the PSM can be changed by altering the mixing ratios of saturated and sample flows, which allows the measurement of particle size distribution in the sub- $3 \mathrm{~nm}$ size range. In this study, the particle concentration obtained for the size range between 1.1 and $2.0 \mathrm{~nm}\left(N_{1.1-2 \mathrm{~nm}}\right)$ was used. In addition, the particle concentration between 2 and $3 \mathrm{~nm}\left(N_{2-3 \mathrm{~nm}}\right)$ was obtained by subtracting the total particle concentration measured with the highest cut-off size of the PSM from the total particle concentration measured with the DMPS. For more discussion about the particle concentration measurements and their uncertainties, see Kontkanen et al. (2017), who have published the data set used in this study.

\subsection{Regression calculations}

Simple linear regressions were calculated to find whether meteorological conditions affect amine concentrations. The statistical significance of the slope of the linear regression of the amine concentration $y$ vs. the ambient condition $x$, i.e., $y=\beta_{1} x+\beta_{0}$, was estimated. The null hypothesis, which means that the slope $\beta_{1}$ is not dependent on the ambient condition $x$ (i.e., $\beta_{1}=0$ ), was examined using test statistics given by the estimate of the slope divided by its standard error $\left(t=\beta_{1} /\right.$ s.e.). The test statistics were compared with the Student's $t$ distribution on $n-2$ (sample size minus the number of regression coefficients) degrees of freedom. The analysis yields also the $p$ value of the slope. The lower the $p$ value is, the stronger the evidence against the null hypothesis. The statistical significance of the slope can be interpreted so that if $p>0.1$, there is no evidence against the null hypothesis, and $p$ values in the ranges $0.05-0.1,0.01-0.05$, and $<0.01$ suggest, respectively, weak, moderate, and strong evidence against the null hypothesis in favor of the alternative. The regressions were calculated for amine concentrations vs. air temperature, relative humidity, wind speed, soil temperature, and soil humidity.

\section{Results}

\subsection{Characterization of MARGA-MS}

An online method for sampling, separating, and detecting amines from the ambient air both in the gas and aerosol phases has been developed. With MARGA-MS, we studied seven different amines: monomethylamine (MMA), dimethylamine (DMA), trimethylamine (TMA), ethylamine (EA), diethylamine (DEA), propylamine (PA), and butylamine (BA); see Figs. S2 and S3 for the chromatogram. The time resolution of measurements was $1 \mathrm{~h}$, and as can be seen in Table 1, the detection limits were low, and precision (10-15\%) and accuracy (11-37\%) for the analytical method of MARGA-MS were moderately good. In addition to improved DLs, MS detection after MARGA also solved the problem with co-elution of amines with different molecular masses and inorganic cations (e.g., $\mathrm{K}^{+}, \mathrm{Mg}_{2}^{+}$). Verriele 
et al. (2012) developed also an IC-MS method for amines with offline sampling with midget impingers. They also noticed that adding MS detection after a conductivity detector overcomes the co-eluting problem of IC separation. They had a four-step gradient elution in their method, and suppression before the conductivity detector. We wanted to keep our method as simple as possible to make it easy to use in the field, and isocratic elution without suppression was good in that purpose. Calibration levels $\left(10,50\right.$, and $\left.300 \mathrm{ng} \mathrm{m}^{-3}\right)$ were selected so that the lowest level was a bit higher than biggest alkyl amine detection limit (DMA, $3.1 \mathrm{ng} \mathrm{m}^{-3}$ ), and the highest was too high to exceed in the measurements. When the measurements started, most of the data were under the lowest calibration point, which increased the uncertainty.

The whole analysis was conducted in the field, so the method had no biases from sample transportation. However, the drawback in the analysis was that DEA and BA, which have the same molecular masses, did not separate completely. From a technical point of view, one of the drawbacks of the MARGA-MS was that the system was quite vulnerable. We lost many measuring days because some part of the system was broken. The MARGA side also needed $\sim 40 \mathrm{~L}$ solutions (e.g., eluents, absorbtion solution for sampling, and internal standard solution) that needed to be changed weekly. The ESI chamber of the MS needed to be cleaned weekly, because oxalic acid was crystallizing into it. Theoretical calculations of the efficiency of the denuder could be found in the Supplement (Fig. S4).

\subsection{Variability of the concentrations}

Figure S5 shows the monthly means and medians of total amine concentrations (tot, sum of gas and aerosol phases) and Fig. 1 shows the box-and-whisker plots to describe the distribution of the measured concentrations. Total amine concentrations were used because we wanted to study how amine sources and partitioning between aerosol (a) and gas phases (g) depend on environmental quantities. Even though the average ratios (gas/(gas+aerosol)) for values above the DL in Table 2 are close to 0.5 , amines were still mainly in the aerosol phase (Tables 2 and S2), which is shown by the more data points above the DL in the aerosol phase. Table S3 shows the number of data points in each month, as well as the mean and median values of concentrations of different amines, ammonia, and ammonium. It can be seen that most concentrations were below the DL especially in the gas phase, so we can conclude that concentrations of amines in the boreal forest are low compared to, for example, ammonia or monoterpene concentrations (Hakola et al., 2012). In Table 3, concentrations in other studies are compared to our findings. Different seasonal patterns were found for different amines and they are described below.

\subsubsection{Monomethylamine}

A spring maximum was observed for MMA(tot) (maximum $50 \mathrm{ng} \mathrm{m}^{-3}$ ) and the concentrations correlated with the sum of $\mathrm{NH}_{3}$ and $\mathrm{NH}_{4}^{+}\left(R^{2}=0.52\right.$, Fig. 2). During spring, we observed two occasions when MMA(tot) and the sum of $\mathrm{NH}_{3}$ and $\mathrm{NH}_{4}^{+}$concentrations increased considerably at the same time. The concentration increase in March is characterized with rain (Fig. 3a) and the later increase in April took place during night with decreasing wind speed and higher temperature (Fig. 3b). This increase could be connected to evaporation from melting snow and ground. Bigg et al. (2001) suggest that water from melting snow penetrates the soil and leaf litter beneath the snow, displacing gases produced by decomposition of organic material. These gases are then released to the air, where they participate in the nucleation process. At humid conditions, this bubbling of gases would be efficient, whereas the evaporation to air would be more efficient on warm, sunny days.

Most of the MMA was in aerosol phase (Tables 3 and S2): monthly mean of aerosol-phase MMA(a) varied between $<2.4$ and $6.8 \mathrm{ng} \mathrm{m}^{-3}$ (Table S3), while monthly means of gas-phase MMA $(\mathrm{g})$ were below the DL throughout the measurements. In early winter (late November to early December), MMA was not detected. $\mathrm{NH}_{x}$ showed similar seasonal variation as MMA with the maximum in March and lower concentrations towards the end of summer. During spring, $\mathrm{NH}_{x}$ was also mainly in aerosol phase.

In earlier studies (Table 3), You et al. (2014) detected gaseous MMA(g) with CIMS in an Alabama forest in summer, at about the same concentrations as our measurements (maximum $\sim 2 \mathrm{ppt}_{\mathrm{v}}$, approximately $3.8 \mathrm{ng} \mathrm{m}^{-3}$ ). Also Freshour et al. (2014) measured MMA(g) with AmPMS in three different sites in the US, and their mean concentrations were at the same level as ours (4-5 ppt $\mathrm{v}_{\mathrm{v}}$, approximately 5.1$6.4 \mathrm{ng} \mathrm{m}^{-3}$ ). Akyüz (2007) took urban outdoor air samples in Turkey during summertime in 2004-2005 and wintertime in 2005-2006, and analyzed them later with GC-MS. MMA(g) mean results were 0.26 and $1.30 \mathrm{ng} \mathrm{m}^{-3}$, respectively. Values were at similar levels to our measurements. That is surprising, because in urban areas we expect many MMA sources (e.g., industry and cars; Ge et al., 2011), so higher mean concentrations would have been expected.

\subsubsection{Trimethylamine}

TMA(tot) had higher concentrations in March after which they declined, before increasing again in July to their maximum concentrations suggesting biogenic sources (Figs. 1, S5). TMA(tot) concentrations also peaked at the end of March during rain simultaneously with MMA(tot) and the sum of $\mathrm{NH}_{3}$ and $\mathrm{NH}_{4}^{+}$increasing from about 1.5 to $6.0 \mathrm{ng} \mathrm{m}^{-3}$, so melting snow and ground could also be the sources of TMA as discussed in Sect. 3.2.1. During summer, TMA(tot) concentrations increased again, concomitant with 

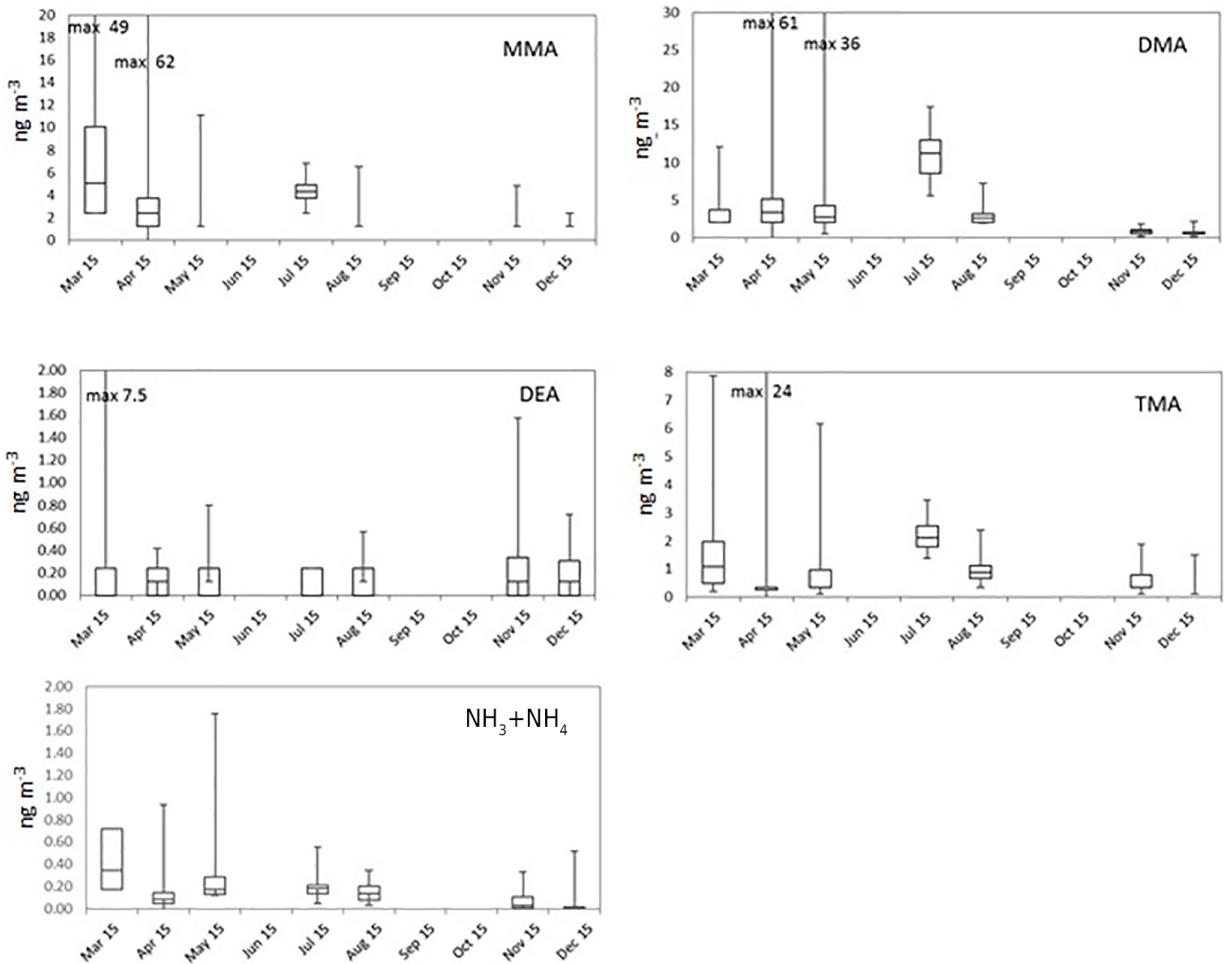

Figure 1. Monthly box-and-whisker plots of the most abundant amines (tot) and summed up ammonia and ammonium. The boxes represent the second and third quartiles and the lines in the boxes the median values. The whiskers show the highest and the lowest observations.

Table 2. Ratio of gas and aerosol phases. $N(\mathrm{~g})$ indicates the number of gas-phase data above the detection limit (DL), $N(\mathrm{a})$ indicates the number of aerosol-phase data above the DL, and $N$ indicates the number of data above the DL at the same time both in the gas and aerosol phases; ratio is gas/(gas+aerosol) (when both values were above the DL).

\begin{tabular}{lrrrrrrrr}
\hline & MMA & DMA & TMA & EA & DEA & PA & BA & NH $_{x}$ \\
\hline$N(\mathrm{~g})$ & 29 & 116 & 308 & 62 & 86 & 20 & 38 & 285 \\
$N($ a $)$ & 183 & 550 & 391 & 82 & 29 & 35 & 26 & 844 \\
$N$ & 9 & 53 & 208 & 21 & 6 & 5 & 3 & 282 \\
Average ratio & 0.41 & 0.44 & 0.29 & 0.48 & - & - & - & 0.35 \\
Min. ratio & 0.18 & 0.09 & 0.10 & 0.05 & - & - & - & 0.05 \\
Max. ratio & 0.52 & 0.83 & 0.90 & 0.95 & - & - & - & 0.84 \\
\hline
\end{tabular}

the sum of $\mathrm{NH}_{3}$ and $\mathrm{NH}_{4}^{+}$in July. The share of the gas phase was roughly half of the aerosol-phase concentration throughout the measurements (Tables 2 and S2). TMA(tot) did not show a clear diurnal variation (Fig. 4).

Kieloaho et al. (2013) collected filter samples of gaseous amines from the same boreal forest as we did from May to October 2011 and they also measured low concentrations for the sum of TMA $(\mathrm{g})$ and $\mathrm{PA}(\mathrm{g})$ in July. In their measurements, the concentrations increased during autumn. You et al. (2014) measured gaseous $\mathrm{C}_{3}$ amines (TMA and PA) with CIMS in a forest in Alabama from June to early July in 2013 and their highest concentration $\left(\sim 15 \mathrm{ppt}_{\mathrm{v}}\right.$, approximately $36 \mathrm{ng} \mathrm{m}^{-3}$ ) was $\sim 10$ times higher than ours $\left(3.5 \mathrm{ng} \mathrm{m}^{-3}\right)$. Dawson et al. (2014) collected TMA samples in ion resin cartridges from late August to mid-September near a cattle farm in Chino, California, and analyzed the samples with IC. Their results varied from 1.3 to $6.8 \mathrm{ppb}_{\mathrm{v}}$ (approximately $3.1-$ $16.4 \mathrm{\mu g} \mathrm{m}^{-3}$ ), so they measured $\sim 1000$ times higher concentrations than we did. This is not surprising, because cattle are a known source of amines. Sellegri et al. (2014) measured amines in March 2002 with CIMS in same boreal forest that we did. They found TMA $(\mathrm{g})$ with mixing ratios 34 $80 \mathrm{ppt}_{\mathrm{v}}$ (approximately $82-193 \mathrm{ng} \mathrm{m}^{-3}$ ), so their results are $\sim 30$ times higher than ours. Ambient conditions were different than ours when they measured TMA, and this could be one reason for the higher concentrations they observed. 
Table 3. Comparison of concentrations of MMA, DMA, TMA, and EA in different sites and seasons, in gas and aerosol phases.

\begin{tabular}{|c|c|c|c|c|c|c|c|}
\hline Amine & Gas $\left(\mathrm{ppt}_{\mathrm{V}}\right)$ & Aerosol $\left(\mathrm{ng} \mathrm{m}^{-3}\right)$ & Site description & Location & Season & Year & Reference \\
\hline \multirow[t]{7}{*}{ MMA } & $<\mathrm{DL}-8.8$ & $<$ DL-61.2 & Rural forest & Finland & Spring-early winter & 2015 & This study \\
\hline & $\max . \sim 2$ & & Rural forest & AL, USA & Summer & 2013 & You et al. (2014) \\
\hline & 5 & & Semi-rural & DE, USA & Summer & 2012 & Freshour et al. (2014) \\
\hline & 4 & & Rural & OK, USA & Spring & 2013 & Freshour et al. (2014) \\
\hline & 4 & & Urban & MN, USA & Autumn & 2012 & Freshour et al. (2014) \\
\hline & $0.26^{\mathrm{d}}$ & & Urban & Turkey & Summer & 2004-2005 & Akyüz (2007) \\
\hline & $1.3^{\mathrm{d}}$ & & Urban & Turkey & Winter & 2005-2006 & Akyüz (2007) \\
\hline \multirow[t]{12}{*}{ DMA } & $<\mathrm{DL}-4.1$ & $<$ DL-55.5 & Rural forest & Finland & Spring-early winter & 2015 & This study \\
\hline & $\max . \sim 7^{\mathrm{a}}$ & & Rural forest & AL, USA & Summer & 2013 & You et al. (2014) \\
\hline & $28^{\mathrm{a}}$ & & Semi-rural & DE, USA & Summer & 2012 & Freshour et al. (2014) \\
\hline & $20^{\mathrm{a}}$ & & Rural & OK, USA & Spring & 2013 & Freshour et al. (2014) \\
\hline & $42^{\mathrm{a}}$ & & Urban & MN, USA & Autumn & 2012 & Freshour et al. (2014) \\
\hline & $2.18^{\mathrm{d}}$ & & Urban & Turkey & Summer & 2004-2005 & Akyüz (2007) \\
\hline & $2.96^{*}$ & & Urban & Turkey & Winter & 2005-2006 & Akyüz (2007) \\
\hline & $<2.7$ & $<2.7$ & Urban & Canada & Summer & 2009 & VandenBoer et al. (2011) \\
\hline & $6.5 \pm 2.1$ & $0.1 \pm 0.2$ & Rural & Canada & Autumn & 2010 & VandenBoer et al. (2012) \\
\hline & $42 \pm 30^{\mathrm{a}}$ & & Rural forest & Finland & May-October & 2011 & Kieloaho et al. (2013) \\
\hline & $\max .10$ & & Urban & GA, USA & Summer & 2009 & Hanson et al. (2011) \\
\hline & & $9.3-20.5$ & Semi-arid & AZ, USA & Whole year & 2012-2013 & Youn et al. (2015) \\
\hline \multirow[t]{12}{*}{ TMA } & $<$ DL-6.1 & & Rural forest & Finland & Spring-early winter & 2015 & This study \\
\hline & $34-80$ & & Rural forest & Finland & Spring & 2002 & Sellegri et al. (2005) \\
\hline & $\max . \sim 20^{\mathrm{b}}$ & & Rural forest & USA & Summer & 2013 & You et al. (2014) \\
\hline & $6^{\mathrm{b}}$ & & Semi-rural & DE, USA & Summer & 2012 & Freshour et al. (2014) \\
\hline & $35^{\mathrm{b}}$ & & Rural & OK, USA & Spring & 2013 & Freshour et al. (2014) \\
\hline & $19^{\mathrm{b}}$ & & Urban & MN, USA & Autumn & 2012 & Freshour et al. (2014) \\
\hline & $15^{\mathrm{b}}$ & & Rural forest & AL, USA & Summer & 2013 & You et al. (2014) \\
\hline & $<2.7^{\mathrm{c}}$ & $<2.7^{\mathrm{c}}$ & Urban & Canada & Summer & 2009 & VandenBoer et al. (2011) \\
\hline & $\sim 1^{\mathrm{c}}$ & $1 \pm 0.6^{\mathrm{c}}$ & Rural & Canada & Autumn & 2010 & VandenBoer et al. (2012) \\
\hline & $21 \pm 23$ & & Rural forest & Finland & May-October & 2011 & Kieloaho et al. (2013) \\
\hline & $\leq 6.8 \times 10^{3}$ & & Agricultural & CA, USA & Autumn & 2013 & Dawson et al. (2014) \\
\hline & & $\max .9 \pm 7$ & Wildfire $\mathrm{e}^{\mathrm{e}}$ & Canada & Summer & 2015 & Place et al. (2017) \\
\hline \multirow[t]{2}{*}{ EA } & $<$ DL-8.2 & & Rural forest & Finland & Spring-early winter & 2015 & This study \\
\hline & $0.35^{\mathrm{d}}$ & & Urban & Turkey & Winter & 2005-2006 & Akyüz (2007) \\
\hline
\end{tabular}

${ }^{a}$ Mass 46, i.e., DMA+EA. ${ }^{b}$ Mass 60 , i.e., TMA+PA. ${ }^{c}$ TMA+DEA. ${ }^{d}$ Units in $n g \mathrm{~m}^{-3}$. ${ }^{\mathrm{e}}$ Samples are collected in British Columbia during wildfires

\subsubsection{Dimethylamine}

DMA(tot) concentrations also increased from about 3 to $6 \mathrm{ng} \mathrm{m}^{-3}$ during the MMA episode in April. Moreover, both particulate- and gas-phase DMA had maximum concentrations in July suggesting a biogenic source (the highest value was $14.5 \mathrm{ng} \mathrm{m}^{-3}$ in the aerosol phase and $7.5 \mathrm{ng} \mathrm{m}^{-3}$ in the gas phase). The particle fraction was again generally more abundant than the gaseous fraction. Because amines can be expected to partition in the aqueous aerosols (Ge et al., 2010), it is not surprising to find them mostly in the aerosol phase, considering the high average relative humidity measured $(>68 \%)$. In August, the concentrations decreased, and they were the lowest during the early winter. Kieloaho et al. (2013) measured also high gas-phase concentrations of the sum of DMA and EA in July, reaching a maximum of $\sim 75 \mathrm{ppt}_{\mathrm{v}}$ (approximately $138 \mathrm{ng} \mathrm{m}^{-3}$ ). In their measurements, the concentration levels decreased in
August, similar to our measurements. High DMA and TMA concentrations in summer could indicate biogenic sources. However, these amines' concentrations did not correlate with monoterpene concentrations like EA (see Sect. 3.2.4). VandenBoer et al. (2011) measured both DMA(g) and DMA(a) with AIM-IC from late June to early July 2009 in an urban area, with highest concentrations of $2.7 \mathrm{ppt}_{\mathrm{v}}$ (approximately $4.6 \mathrm{ng} \mathrm{m}^{-3}$ ) and $2.7 \mathrm{ng} \mathrm{m}^{-3}$ which were at the same level as our DMA(g) in July $\left(7.5 \mathrm{ng} \mathrm{m}^{-3}\right)$. Hanson et al. (2011) also measured DMA concentrations with AmPMS in an urban area with a little higher gas-phase concentrations (maximum of $10 \mathrm{ppt}_{\mathrm{v}}$, approximately $19 \mathrm{ng} \mathrm{m}^{-3}$ ) than in the studies mentioned earlier. Ge et al. (2010) gives DMA also urban sources (e.g., tobacco smoke, automobiles), so that can explain results from Hanson et al. (2011). Youn et al. (2015) measured DMA aerosols and cloud water, and they noticed that DMA concentrations in $\mathrm{PM}_{1}$ aerosols peaked in September. We were also expecting high concentrations in autumn, 


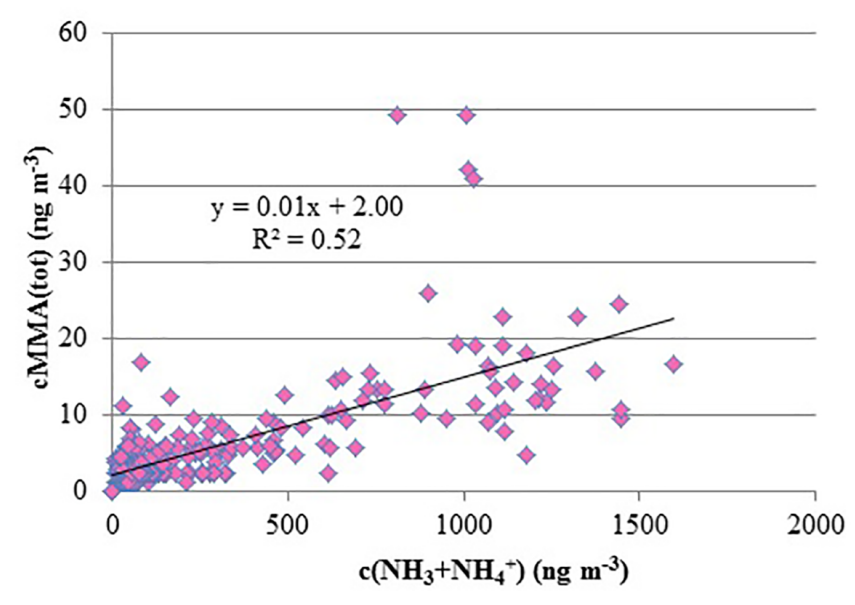

Figure 2. Concentrations $\left(\mathrm{ng} \mathrm{m}^{-3}\right)$ of total MMA vs. concentrations of $\mathrm{NH}_{3}+\mathrm{NH}_{4}^{+}$in March and April 2015.

but due to instrumental problems, we unfortunately missed the season. In July, we measured from $\mathrm{PM}_{10}$ particles the average concentration of $8.4 \mathrm{ng} \mathrm{m}^{-3}$, and Youn et al. (2015) measured from $\mathrm{PM}_{1}$ particles about twice as high concentration. Different measurement sites could explain the difference. Youn et al., also noticed that DMA(a) displays a unimodal size distribution with dominant peak between 0.18 and $0.56 \mu \mathrm{m}$, and concluded that it indicates aminium salt formation with sulfate.

In August, DMA(tot) had a diurnal variation with a daytime maximum (Fig. 4), but during some nights the concentrations also increased slightly. The DMA(tot) afternoon maxima could be caused by re-emission of DMA that has earlier deposited on surfaces and evaporates when temperature increases during the afternoon. The maximum could also be related to direct biogenic emission. Usually ambient concentrations of biogenic volatile organic compounds, which have temperature dependent emissions, peak during nighttime due to weak atmospheric mixing and lack of hydroxyl radical reactions which only take place during daytime (Hakola et al., 2012). The concentrations of light-dependent biogenic volatile organic compound (BVOC) emissions such as isoprene have daytime maxima because they are emitted only during daytime. Thus, the DMA source could be light dependent. DMA(tot) peaks also at night. Because the atmospheric mixing in the night is weak and there are no $\mathrm{OH}$ reactions, even small emissions can be trapped in a shallower atmospheric boundary layer and cause the increase in concentrations.

\subsubsection{Ethylamine}

EA(tot) concentrations were low throughout the measurements but showed a clear diurnal variation in July with a maximum at night (Fig. 5). Monoterpene concentrations were measured simultaneously at the same site and had a similar diurnal pattern. This type of diurnal variation is typical for many reactive compounds having local sources in a boreal forest (Hakola et al., 2012). Low daytime concentrations are due to strong atmospheric mixing and reactions with an $\mathrm{OH}$ radicals. The rate coefficients of alkyl amines are slightly lower but comparable to monoterpene reactions with $\mathrm{OH}$ radical. The most common monoterpenes in the boreal forest are $\alpha$-pinene, 3 -carene and $\beta$ pinene (Hakola et al., 2012). Their rate coefficients for reaction with $\mathrm{OH}$ are $53.7 \times 10^{-12}, 88 \times 10^{-12}$, and $78.9 \times$ $10^{-12} \mathrm{~cm}^{3}$ molecule ${ }^{-1} \mathrm{~s}^{-1}$, respectively (Atkinson, 1994), whereas MMA, EA, DMA, and TMA rate coefficients with $\mathrm{OH}$ are $22.26 \times 10^{-12}, 29.85 \times 10^{-12}, 65.53 \times 10^{-12}$, and $69.75 \times 10^{-12} \mathrm{~cm}^{3}$ molecule ${ }^{-1} \mathrm{~s}^{-1}$, respectively (US EPA, 2017). Similar diurnal patterns and reactivities indicate that EA has a biogenic source. Kürten et al. (2016) measured $C_{2}$ amines (i.e., DMA and EA) with CI-APi-TOF in Germany near three dairy farms and a forest from May to June 2014. They did not observe clear diurnal variation for $\mathrm{C}_{2}$ amines. In our measurements, EA and DMA had opposite diurnal variations (see Sect. 3.2.3). That could be an explanation for the observations of Kürten et al. (2016), where both $\mathrm{C}_{2}$ amines were measured together. Akyüz (2007) measured $\mathrm{EA}(\mathrm{g}) 0.35 \mathrm{ng} \mathrm{m}^{-3}$ (mean concentration) in an urban area in Turkey during the winters of 2005-2006, and the concentrations were at the same level as ours.

\subsection{Correlations between meteorological quantities and amines}

We noticed that the concentrations of DMA $(\mathrm{g})$ followed, although vaguely, the variations of both air and soil temperature (Fig. S6), so it was reasonable to study whether there are any clear relationships between the amine concentrations and parameters describing ambient conditions. We calculated linear regressions of amines, ammonia, and ammonium vs. air relative humidity $(\mathrm{RH})$ and temperature $(T)$ as well as soil temperature (ST) and soil humidity (SH). The results of the linear regression analyses of the amines, ammonia, ammonium, and the ambient conditions are presented in Tables S4 and S5 for the gas and aerosol phases, respectively.

In the gas phase, DMA had the strongest correlation with ambient condition parameters, suggesting that DMA(g) concentrations increase with increasing air temperature, soil temperature, and soil humidity but decrease with increasing atmospheric humidity and wind speed. The scatter plots of DMA (g) compared vs. these parameters (Fig. 6) show, however, that the relationships are different in different seasons. The most consistent relationships of $\mathrm{DMA}(\mathrm{g})$ are with air and soil temperature; the slopes of the linear regressions are positive for all of the data and for summer alone (Fig. 7).

In the gas phase, the second strongest correlations - even though they are weak - are those of TMA against environmental conditions (Table S4). Interestingly, when looking at all data, TMA $(\mathrm{g})$ concentration seems to decrease with in- 

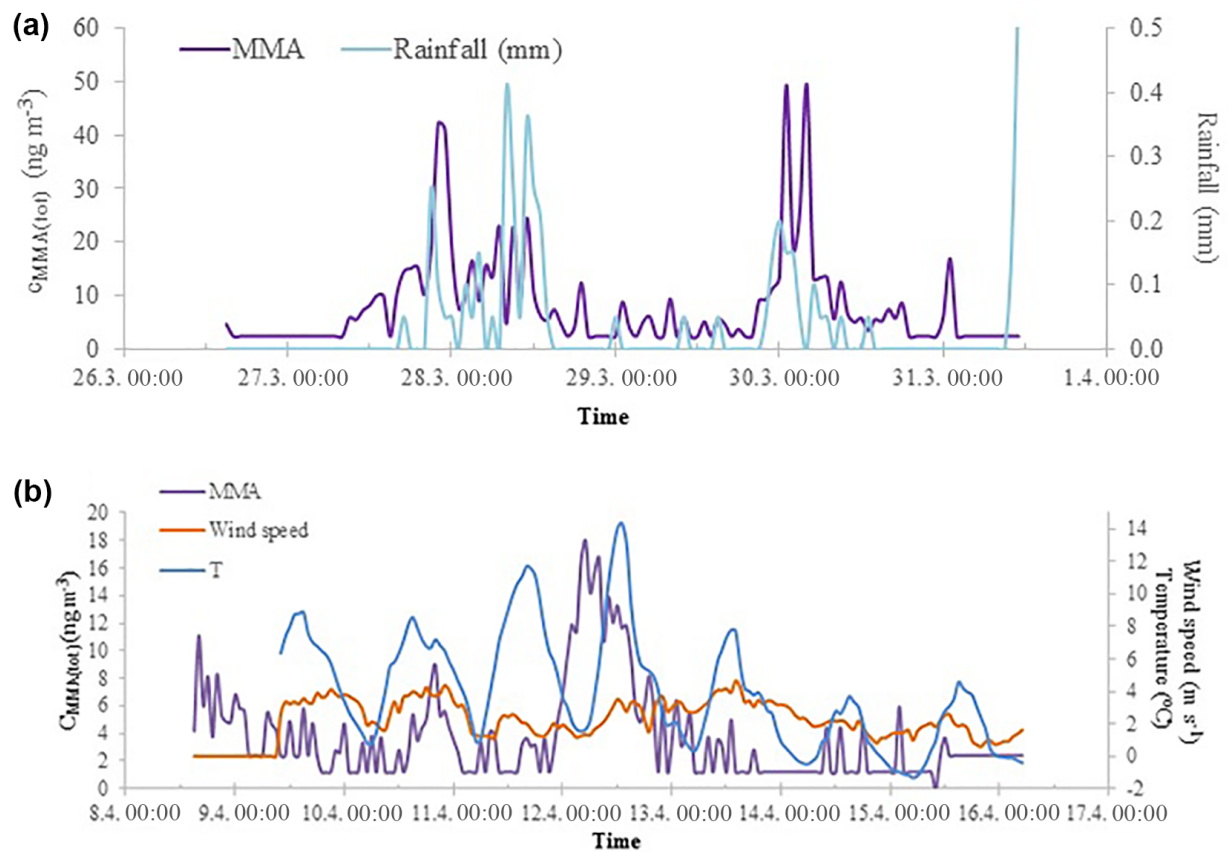

Figure 3. MMA(tot) concentrations and rainfall measured in Hyytiälä during spring 2015 in March (a) and MMA(tot) concentrations, wind speed, and ambient temperature in April (b).

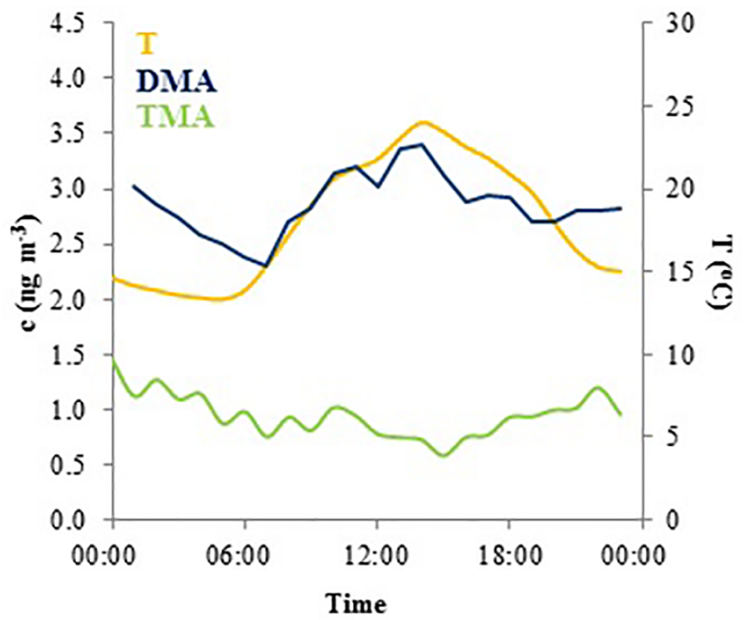

Figure 4. Mean diurnal variation of total DMA (blue), total TMA (green) concentrations and temperature (yellow) in August 2015.

creasing air and soil temperature (Fig. S7), opposite to the relationship of DMA and temperature. As already mentioned, TMA concentrations were high in spring and they are likely to originate partly from melting snow and ground, whereas DMA might have biogenic sources in summer, which could explain different correlation behavior. The scatter plot of TMA(g) vs. temperature (Fig. S7) also reveals that the relationship is not consistent in all seasons: in summer, it is even a vaguely positive, statistically not significant positive relationship. The ammonia concentration increased with air

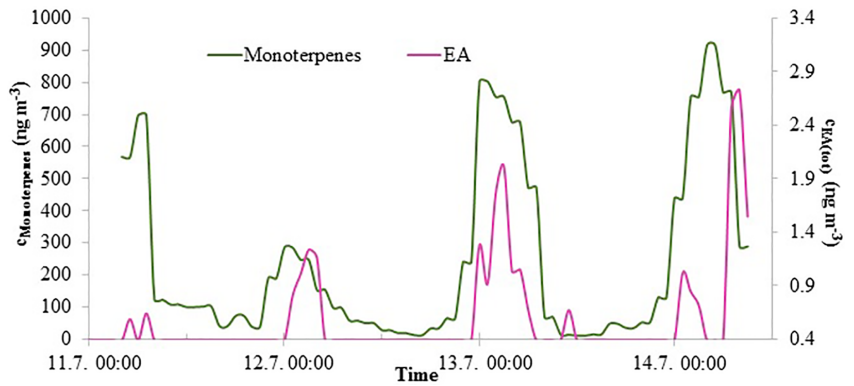

Figure 5. EA(tot) and monoterpene concentrations in Hyytiälä in July 2015. The EA(tot) concentration axis starts from $0.36 \mathrm{ng} \mathrm{m}^{-3}$, because values under that are below the detection limit.

temperature consistent with Makkonen et al. (2014) and decreased with increasing relative humidity. The latter suggests that at high humidity surfaces are moist and ammonia gets absorbed onto the water.

All the gas-phase amines except MMA were found to have a positive correlation with soil water content. The studied amines are water soluble and therefore negative correlation would be expected if the soil would act only as a sink. However, our results suggest that soil processes are producing amines and they may be enhanced with increasing humidity. Forest soils are a reservoir of the alkyl amines (Kieloaho et al., 2016) and modeling studies have shown that they can act as a source of alkyl amines to the atmosphere (Kieloaho et al., 2017). With their model, Kieloaho et al. (2017) found a positive correlation with soil temperature for soil-to-atmosphere 

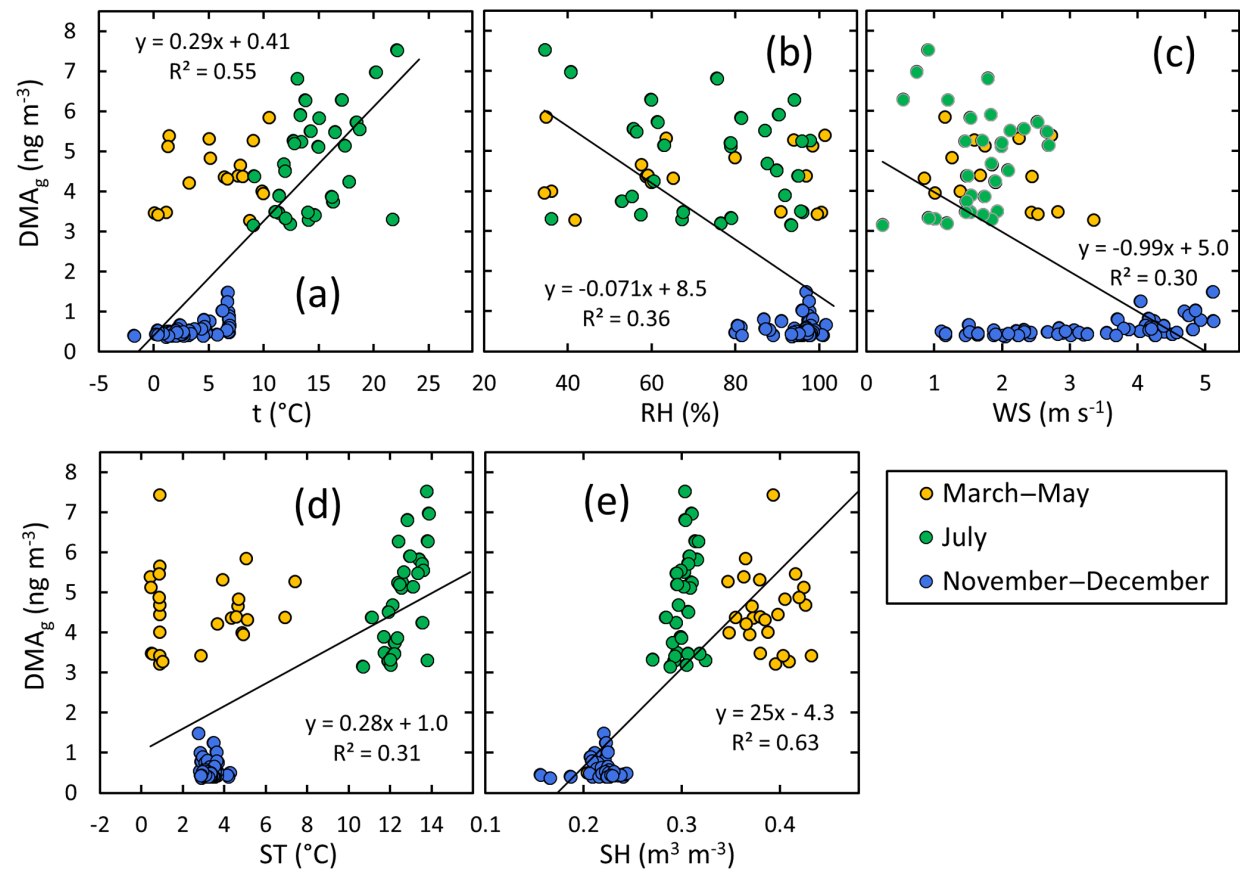

Figure 6. DMA in the gas phase vs. selected ambient condition parameters: (a) air temperature, (b) relative humidity, (c) wind speed, (d) soil temperature, and (e) soil humidity in spring, summer, and early winter. The linear regressions shown in the plots were calculated using the data points of all seasons.

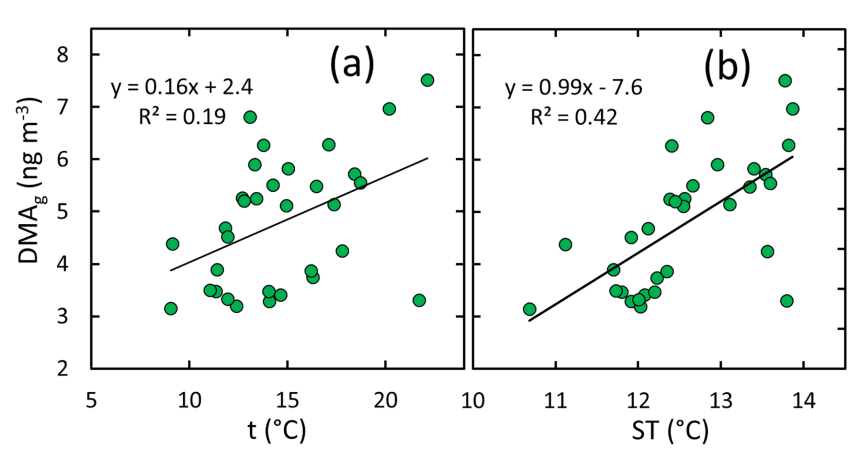

Figure 7. DMA in the gas phase vs. (a) air temperature and (b) soil temperature in summer.

flux of DMA, but correlation with soil water content was opposite to our observation.

\subsection{Correlations of amines with nanoparticle concentrations}

In addition to the dependency of amine concentrations on ambient conditions, the relationships between aerosol number and amine concentrations were studied with a similar regression analysis. The amine concentrations were compared with the total number concentration integrated from the size distributions measured with the DMPS $\left(N_{\text {tot }}\right)$, with the aerosol number concentrations in the size ranges $1.1-2$ and $2-3 \mathrm{~nm}$, measured with the PSM $\left(N_{1.1-2 \mathrm{~nm}}\right.$ and $N_{2-3} \mathrm{~nm}$, respectively) and with the aerosol particle and cluster number concentrations between 3 and $25 \mathrm{~nm}$ measured with the DMPS $\left(N_{3-25} \mathrm{~nm}\right)$. The regression analysis results for the gasphase amines and aerosol-phase amines are presented in Tables S6 and S7, respectively.

The period during which both the MARGA-MS detected $\operatorname{DMA}(\mathrm{g})$ concentrations above the detection limit and the PSM detected cluster-mode aerosols simultaneously was short. There were 33 data points for the regression analysis. There was a weak positive correlation between them (Fig. 8) even though the correlation was statistically not significant $\left(R^{2}=0.06, p=0.18\right.$, Table S6). The correlation had some dependence on the ambient conditions: air relative humidity $(\mathrm{RH})$ and temperature $(T)$ as well as soil temperature (ST) and soil humidity (SH). The correlation was more significant when both soil and air were humid (RH $>90 \%$, $\mathrm{SH}>0.3 \mathrm{~m}^{3} \mathrm{~m}^{-3}$ ). The linear regression calculated by using only those data that were measured at $\mathrm{RH}>90 \%$ has a higher correlation coefficient and slope is statistically significant $\left(R^{2}=0.63, p=0.006\right.$, Table S6, Fig. 8 b), but it has to be noted that there were only 10 simultaneous data points at the high RH.

There was no correlation between the slightly larger aerosols $\left(N_{2-3} \mathrm{~nm}\right)$ and DMA(g) (Table S6), suggesting that DMA $(\mathrm{g})$ took part in the initial steps of secondary aerosol formation namely clustering. This is qualitatively in agreement with an experimental CLOUD chamber study where it has been demonstrated that even very small amounts of DMA 
(a)

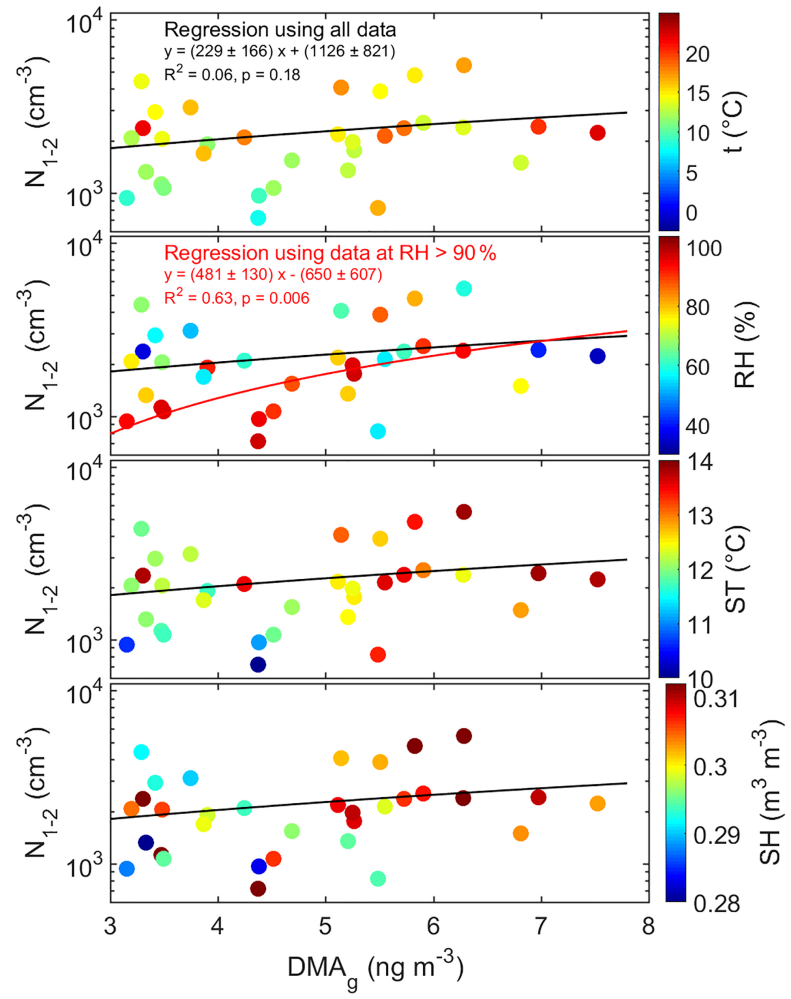

Figure 8. Cluster-mode aerosol number concentration $\left(N_{1.1-2 \mathrm{~nm}}\right)$ as a function of DMA concentration in the gas phase and colorcoded with (a) air temperature $(t)$, (b) air relative humidity $(\mathrm{RH})$, (c) soil temperature (ST), and (d) soil humidity (SH). In all subplots, the black line shows the linear regression calculated by using all data, and in panel (b) the red line shows in addition the linear regression by using only those data that were measured at $\mathrm{RH}>90 \%$.

greatly enhance the formation of nanoparticles (Almeida et al., 2013; Lehtipalo et al., 2016). In the aerosol phase, DMA was the only amine that had a statistically significant correlation with the cluster-mode number concentrations and where the gas-phase correlation coefficient was higher at high relative humidity (Table S7). Other ambient condition quantities apparently did not affect this relationship (Fig. 8).

There were considerably more simultaneous data points of the cluster-mode aerosol number concentration and ammonia $\left(\mathrm{NH}_{3}\right)$. The correlation $N_{1.1-2 \mathrm{~nm}}$ vs. $\mathrm{NH}_{3}$ was statistically significant $\left(R^{2}=0.13, p<0.001\right.$, Table $\left.\mathrm{S} 6\right)$. In addition, this correlation apparently also depended on the ambient conditions. This was visualized by color-coding the scatter plot of cluster-mode particle number concentrations vs. ammonia concentration with air temperature (Fig. 9a), relative humidity (Fig. 9b), soil temperature (Fig. 9c), and soil humidity (Fig. 9c). The plots show that in warm $\left(T>15^{\circ} \mathrm{C}\right.$, $\left.\mathrm{ST}>14^{\circ} \mathrm{C}\right)$ and dry $\left(\mathrm{RH}<60 \%, 495 \mathrm{SH}<0.25 \mathrm{~m}^{3} \mathrm{~m}^{-3}\right)$ conditions the positive correlation was more obvious (Fig. 9). In the aerosol phase, ammonium $\left(\mathrm{NH}_{4}^{+}\right)$did not correlate at all with the cluster-mode particle number concentration but (a)

(b)

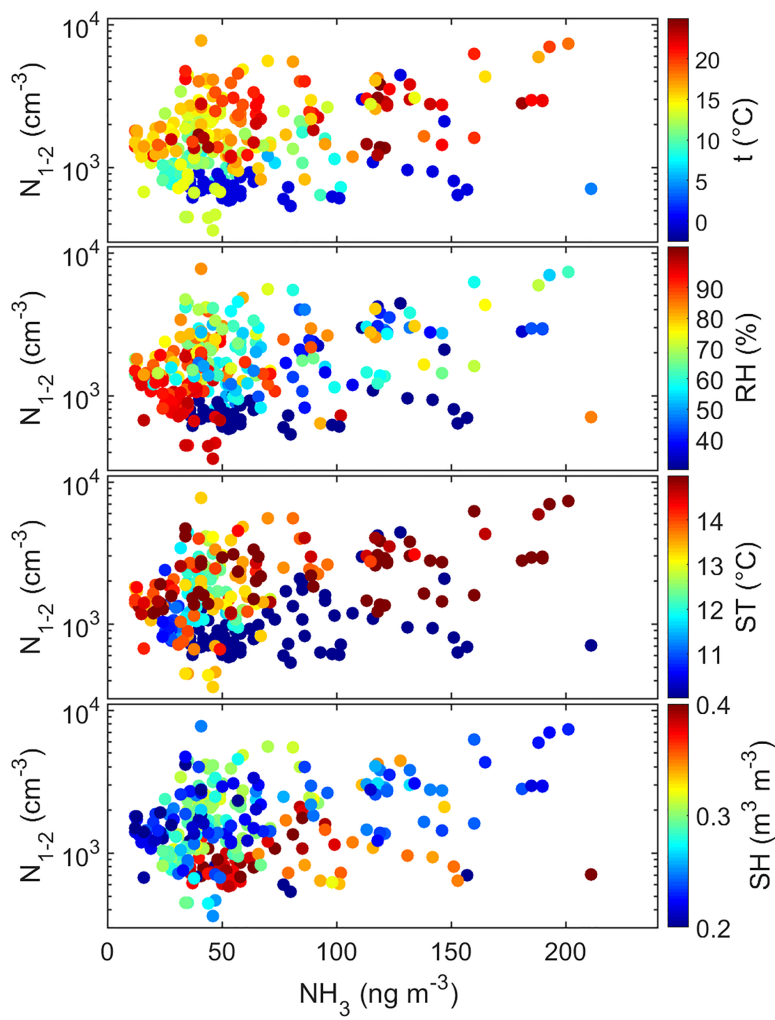

Figure 9. Cluster-mode aerosol number concentration $\left(N_{1.1-2 \mathrm{~nm}}\right)$ as a function of ammonia $\left(\mathrm{NH}_{3}\right)$ concentration and color-coded with (a) air temperature $(t)$, (b) air relative humidity $(\mathrm{RH})$, (c) soil temperature (ST), and (d) soil humidity ( $\mathrm{SH})$.

positively with the total number concentration (Table S6) as expected. The other amines did not have any significant correlations with the aerosols in the smallest aerosol size ranges.

\section{Conclusions}

An online method using in situ ion chromatography with mass-spectrometric detection for measuring amines in low concentrations from the ambient air both in the gas and aerosol phases was developed. In situ amine and ammonia measurements were conducted at the SMEAR II station (Hyytiälä, Finland) from March to December 2015, covering altogether about 8 weeks. Concentrations of seven different amines and ammonia in aerosol and gas phases were measured with $1 \mathrm{~h}$ time resolution.

The developed MARGA-MS method was suitable for field measurements of amines. The DLs were low (0.2 $11.4 \mathrm{ng} \mathrm{m}^{-3}$ ), and the accuracy and precision of IC-MS analysis were moderately good. With the method, amines with same masses or same retention time were separated; only DEA and BA were incompletely separated. However, MARGA-MS had some technical drawbacks (e.g., consumption of $\sim 40 \mathrm{~L}$ of solutions per week). 
The amines turned out to be a heterogeneous group of compounds; different amines are likely to have different sources. All amines had higher concentrations in the aerosol phase than in the gas phase. MMA and TMA concentrations were the highest in spring, concomitant with ammonia and ammonium. Melting of snow and ground can be the source of these compounds. The decomposing litter and organic soil layer beneath snow can release organic compounds to snow cover and to the atmosphere.

TMA had an additional maximum simultaneously with DMA during summer, and EA was only detected in July. The summer maxima could indicate biogenic sources. However, unlike EA, DMA and TMA did not show similar diurnal variation as monoterpenes. The diurnal variation is determined by the balance between emissions, reactivity, and mixing in the atmosphere. Usually ambient concentrations of biogenic volatile organic compounds, which have temperature dependent emissions, peak during nighttime due to inefficient mixing and lack of hydroxyl radical reactions which only take place during daytime. The missing daytime minima of DMA and TMA can be due to light-dependent biogenic sources, or TMA and DMA might be re-emitted from surfaces during daytime, when temperature increases.

All amines except MMA correlated positively with soil humidity, which could indicate a humidity-dependent production mechanism. Gas-phase DMA correlated positively with small 1.1-2 nm aerosols, when both soil and air were humid. It did not correlate with slightly larger aerosols at all, suggesting that gas-phase DMA may be important in new aerosol formation.

Data availability. The data sets can be accessed by contacting the corresponding author.

Supplement. The supplement related to this article is available online at: https://doi.org/10.5194/acp-18-6367-2018-supplement.

Competing interests. The authors declare that they have no conflict of interest.

Acknowledgements. The financial support by the Academy of Finland Centre of Excellence program (project no. 272041) and Academy Research Fellow program (project no. 275608) are gratefully acknowledged.

Edited by: Armin Sorooshian

Reviewed by: three anonymous referees

\section{References}

Aalto, P., Hämeri, K., Becker, E., Weber, R., Salm, J., Mäkelä, J. M., Hoell, C., O’Dowd, C. D., Karlsson, H., Hansson, H.-C., Väkevä, M., Koponen, I. K., Buzorius, G., and Kulmala, M.: Physical characterization of aerosol particles during nucleation events, Tellus B, 53, 344-358, 2001.

Akyüz, M.: Simultaneous determination of aliphatic and aromatic amines in indoor and outdoor air samples by gas chromatography-mass spectrometry, Talanta, 71, 486-492, 2007.

Almeida, J., Schobesberger, S., Kurten, A., Ortega, I. K., Kupiainen-Maatta, O., Praplan, A. P., Adamov, A., Amorim, A., Bianchi, F., Breitenlechner, M., David, A., Dommen, J., Donahue, N. M., Downard, A., Dunne, E., Duplissy, J., Ehrhart, S., Flagan, R. C., Franchin, A., Guida, R., Hakala, J., Hansel, A., Heinritzi, M., Henschel, H., Jokinen, T., Junninen, H., Kajos, M., Kangasluoma, J., Keskinen, H., Kupc, A., Kurten, T., Kvashin, A. N., Laaksonen, A., Lehtipalo, K., Leiminger, M., Leppa, J., Loukonen, V., Makhmutov, V., Mathot, S., McGrath, M. J., Nieminen, T., Olenius, T., Onnela, A., Petaja, T., Riccobono, F., Riipinen, I., Rissanen, M., Rondo, L., Ruuskanen, T., Santos, F. D., Sarnela, N., Schallhart, S., Schnitzhofer, R., Seinfeld, J. H., Simon, M., Sipila, M., Stozhkov, Y., Stratmann, F., Tome, A., Trostl, J., Tsagkogeorgas, G., Vaattovaara, P., Viisanen, Y., Virtanen, A., Vrtala, A., Wagner, P. E., Weingartner, E., Wex, H., Williamson, C., Wimmer, D., Ye, P., Yli-Juuti, T., Carslaw, K. S., Kulmala, M., Curtius, J., Baltensperger, U., Worsnop, D. R., Vehkamaki, H., and Kirkby, J.: Molecular Understanding of Sulphuric Scid-amine Particle Nucleation in the Atmosphere, Nature, 502, 359-363, https://doi.org/10.1038/nature12663, 2013.

Atkinson, R.: Gas-phase troposheric chemistry of organic compounds, Journal of Physical and Chemical Reference Data, Monograph 2, 216 pp., 1994.

Bigg, E. K.: The aerosol in a boreal forest in spring, Tellus B, 53, 510-551, https://doi.org/10.3402/tellusb.v53i4.16626, 2001.

Chang, I. H., Lee, D. S., and Ock, S. H.: Condensertype diffusion denuders for the collection of sulfur dioxide in a cleanroom, Anal. Bioanal. Chem., 375, 456-459, https://doi.org/10.1007/s00216-002-1682-3, 2003.

Dawson, M. L., Perraud, V., Gomez, A., Arquero, K. D., Ezell, M. J., and Finlayson-Pitts, B. J.: Measurement of gas-phase ammonia and amines in air by collection onto an ion exchange resin and analysis by ion chromatography, Atmos. Meas. Tech., 7, 27332744, https://doi.org/10.5194/amt-7-2733-2014, 2014.

Finlayson-Pitts, B. J. and Pitts, J. N.: Chemistry of the upper and lower atmosphere: Theory, experiments and applications, Academic, US, 2000.

Freshour, N. A., Carlson, K. K., Melka, Y. A., Hinz, S., Panta, B., and Hanson, D. R.: Amine permeation sources characterized with acid neutralization and sensitivities of an amine mass spectrometer, Atmos. Meas. Tech., 7, 3611-3621, https://doi.org/10.5194/amt-7-3611-2014, 2014.

Ge, X., Wexler, A. S., and Clegg, S. L.: Atmospheric amines - Part II, Thermodynamic properties and gas/particle partitioning, Atmos. Environ., 45, 561-577, https://doi.org/10.1016/j.atmosenv.2010.10.013, 2010.

Ge, X., Wexler, A. S., and Clegg, S. L.: Atmospheric amines - Part I, A review, Atmos. Environ., 45, 524-546, https://doi.org/10.1016/j.atmosenv.2010.10.012, 2011. 
Hakola, H., Hellén, H., Hemmilä, M., Rinne, J., and Kulmala, M.: In situ measurements of volatile organic compounds in a boreal forest, Atmos. Chem. Phys., 12, 11665-11678, https://doi.org/10.5194/acp-12-11665-2012, 2012.

Hanson, D. R., McMurry, P. H., Jiang, J., Tanner, D., and Huey, L. G.: Ambient pressure proton transfer mass spectrometry: detection of amines and ammonia, Environ. Sci. Technol., 45, 88818888, 2011.

Hari, P. and Kulmala, M.: Station for measuring ecosystematmosphere relations (SMEAR II), Boreal Environ. Res., 10, 315-322, 2005.

Hellén, H., Kieloaho, A., and Hakola, H.: Gas-phase alkyl amines in urban air; comparison with a boreal forest site and importance for local atmospheric chemistry, Atmos. Environ., 94, 192-197, 2014.

Huang, R.-J., Li, W.-B., Wang, Y.-R., Wang, Q. Y., Jia, W. T., Ho, K.-F., Cao, J. J., Wang, G. H., Chen, X., EI Haddad, I., Zhuang, Z. X., Wang, X. R., Prévôt, A. S. H., O’Dowd, C. D., and Hoffmann, T.: Determination of alkylamines in atmospheric aerosol particles: a comparison of gas chromatography-mass spectrometry and ion chromatography approaches, Atmos. Meas. Tech., 7, 2027-2035, https://doi.org/10.5194/amt-7-2027-2014, 2014.

IPCC: Climate Change 2013: The Physical Science Basis. Contribution of Working Group I to the Fifth Assessment Report of the Intergovernmental Panel on Climate Change, edited by: Stocker, T. F., Qin, D., Plattner, G.-K., Tignor, M., Allen, S. K., Boschung, J., Nauels, A., Xia, Y., Bex, V., and Midgley, P. M., Cambridge University Press, Cambridge, United Kingdom and New York, NY, USA, 1535 pp., 2013.

Junninen, H., Lauri, A., Keronen, P., Aalto, P., Hiltunen, V., Hari, P., and Kulmala, M.: Smart-SMEAR: on-line data exploration and visualization tool for SMEAR stations, Boreal Environ. Res., 14, 447-457, 2009

Kieloaho, A.-J., Hellén, H., Hakola, H., Manninen, H. E., Nieminen, T., Kulmala, M., and Pihlatie, M.: Gas-phase alkylamines in a boreal Scots pine forest air, Atmos. Environ., 80, 369-377, https://doi.org/10.1016/j.atmosenv.2013.08.019, 2013.

Kieloaho, A.-J., Pihlatie, M., Carrasco, M. D., Kanerva, S., Parshintsev, J., Riekkola, M.-L., Pumpanen, J., and Heinonsalo, J.: Stimulation of soil organic nitrogen pool: The effect of plant and soil organic matter degrading enzymes, Soil Biol. Biochem., 96, 97-106, https://doi.org/10.1016/j.soilbio.2016.01.013, 2016.

Kieloaho, A.-J., Pihlatie, M., Launiainen, S., Kulmala, M., Riekkola, M.-L., Parshintsev, J., Mammarella, I., Vesala, T., and Heinonsalo, J.: Soil concentrations and soil-atmosphere exchange of alkylamines in a boreal Scots pine forest, Biogeosciences, 14, 1075-1091, https://doi.org/10.5194/bg-14-10752017, 2017.

Kontkanen, J., Lehtipalo, K., Ahonen, L., Kangasluoma, J., Manninen, H. E., Hakala, J., Rose, C., Sellegri, K., Xiao, S., Wang, L., Qi, X., Nie, W., Ding, A., Yu, H., Lee, S., Kerminen, V.M., Petäjä, T., and Kulmala, M.: Measurements of sub-3 nm particles using a particle size magnifier in different environments: from clean mountain top to polluted megacities, Atmos. Chem. Phys., 17, 2163-2187, https://doi.org/10.5194/acp17-2163-2017, 2017.

Kulmala, M., Kontkanen, J., Junninen, H., Lehtipalo, K., Manninen, H. E., Nieminen, T., Petaja, T., Sipilä, M. J., Schobesberger, S., Rantala, P., Franchin, A., Jokinen, T., Järvinen, E.
P., Äijälä, M., Kangasluoma, J. P., Hakala, J. P., Aalto, P. P., Paasonen, P., Mikkilä, J., Vanhanen, J., Aalto, J., Hakola, H., Makkonen, U., Ruuskanen, T., Mauldin III, R., Duplissy, J., Vehkamäki, H., Bäck, J., Kortelainen, A., Riipinen, I., Kurten, T. C., Johnston, M., Smith, J., Ehn, M. K., Mentel, T., Lehtinen, K., Laaksonen, A., Kerminen, V.-M., and Worsnop, D.: Direct observations of atmospheric nucleation, Science, 339, 943-946, https://doi.org/10.1126/science.1227385, 2013.

Kürten, A., Bergen, A., Heinritzi, M., Leiminger, M., Lorenz, V., Piel, F., Simon, M., Sitals, R., Wagner, A. C., and Curtius, J.: Observation of new particle formation and measurement of sulfuric acid, ammonia, amines and highly oxidized organic molecules at a rural site in central Germany, Atmos. Chem. Phys., 16, 1279312813, https://doi.org/10.5194/acp-16-12793-2016, 2016

Kurtén, T., Loukonen, V., Vehkamäki, H., and Kulmala, M.: Amines are likely to enhance neutral and ion-induced sulfuric acid-water nucleation in the atmosphere more effectively than ammonia, Atmos. Chem. Phys., 8, 4095-4103, https://doi.org/10.5194/acp-84095-2008, 2008.

Lehtipalo, K., Rondo, L., Kontkanen, J., Schobesberger, S., Jokinen, T., Sarnela, N., Kurten, A., Ehrhart, S., Franchin, A., Nieminen, T., Riccobono, F., Sipila, M., Yli-Juuti, T., Duplissy, J., Adamov, A., Ahlm, L., Almeida, J., Amorim, A., Bianchi, F., Breitenlechner, M., Dommen, J., Downard, A. J., Dunne, E. M., Flagan, R. C., Guida, R., Hakala, J., Hansel, A., Jud, W., Kangasluoma, J., Kerminen, V.-M., Keskinen, H., Kim, J., Kirkby, J., Kupc, A., Kupiainen-Määttä, O., Laaksonen, A., Lawler, M. J., Leiminger, M., Mathot, S., Olenius, T., Ortega, I. K., Onnela, A., Petäjä, T., Praplan, A., Rissanen, M. P., Ruuskanen, T., Santos, F. D., Schallhart, S., Schnitzhofer, R., Simon, M., Smith, J. M., Tröstl, J., Tsagkogeorgas, G., Tome, A., Vaattovaara, P., Vehkamäki, H., Vrtala, A. E., Wagner, P. E., Williamson, C., Wimmer, D., Winkler, P. M., Virtanen, A., Donahue, N. M. Carslaw, K. S., Baltensperger, U., Riipinen, I., Curtius, J., Worsnop, D. R., and Kulmala, M.: The effect of acid-base clustering and ions on the growth of atmospheric nano-particles, Nat. Commun., 7, 11594, https://doi.org/10.1038/ncomms11594, 2016.

Makkonen, U., Virkkula, A., Mäntykenttä, J., Hakola, H., Keronen, P., Vakkari, V., and Aalto, P. P.: Semi-continuous gas and inorganic aerosol measurements at a Finnish urban site: comparisons with filters, nitrogen in aerosol and gas phases, and aerosol acidity, Atmos. Chem. Phys., 12, 5617-5631, https://doi.org/10.5194/acp-12-5617-2012, 2012.

Makkonen, U., Virkkula, A., Hellén, H., Hemmilä, M., Mäntykenttä, J., Äijälä, M., Ehn, M., Junninen, H., Keronen, P., Petäjä, T., Worsnop, D. R., Kulmala, M., and Hakola, H.: Semicontinuous gas and inorganic aerosol measurements at a boreal forest site: seasonal and diurnal cycles of $\mathrm{NH}_{3}, \mathrm{HONO}$ and $\mathrm{HNO}_{3}$, Boreal Environ. Res., 19 (suppl. B), 311-328, 2014.

Murphy, S. M., Sorooshian, A., Kroll, J. H., Ng, N. L., Chhabra, P., Tong, C., Surratt, J. D., Knipping, E., Flagan, R. C., and Seinfeld, J. H.: Secondary aerosol formation from atmospheric reactions of aliphatic amines, Atmos. Chem. Phys., 7, 2313-2337, https://doi.org/10.5194/acp-7-2313-2007, 2007.

Paasonen, P., Olenius, T., Kupiainen, O., Kurtén, T., Petäjä, T., Birmili, W., Hamed, A., Hu, M., Huey, L. G., Plass-Duelmer, C., Smith, J. N., Wiedensohler, A., Loukonen, V., McGrath, M. J., Ortega, I. K., Laaksonen, A., Vehkamäki, H., Kerminen, V.-M., and Kulmala, M.: On the formation of sulphuric acid - amine 
clusters in varying atmospheric conditions and its influence on atmospheric new particle formation, Atmos. Chem. Phys., 12, 9113-9133, https://doi.org/10.5194/acp-12-9113-2012, 2012.

Parshintsev, J., Rönkkö, T., Helin, A., Hartonen, K., and Riekkola, M.-L.: Determination of atmospheric amines by on-fiber derivatizationsolid-phase microextraction with 2,3,4,5,6-pentafluoroben-zylchloroformate and 9fluorenylmethoxycarbonyl chloride, J. Chromatogr. A, 1376, 46-52, 2015.

Place, B. K., Quilty, A. T., Di Lorenzo, R. A., Ziegler, S. E., and VandenBoer, T. C.: Quantitation of 11 alkylamines in atmospheric samples: separating structural isomers by ion chromatography, Atmos. Meas. Tech., 10, 1061-1078, https://doi.org/10.5194/amt-10-1061-2017, 2017.

Ruiz-Jiminez, J., Hautala, S. S., Parshintsev, J., Laitinen, T., Hartonen, K., Petäjä, T., Kulmala, M., and Riekkola, M.-L.: Aliphatic and aromatic amines in atmospheric aerosol particles: comparison of three techniques in liquid chromatography-mass spectrometry and method development, Talanta, 97, 55-62, 2012.

Sellegri, K., Hanke, M., Umann, B., Arnold, F., and Kulmala, M.: Measurements of organic gases during aerosol formation events in the boreal forest atmosphere during QUEST, Atmos. Chem. Phys., 5, 373-384, https://doi.org/10.5194/acp-5373-2005, 2005.

Sipilä, M., Sarnela, N., Jokinen, T., Junninen, H., Hakala, J., Rissanen, M. P., Praplan, A., Simon, M., Kürten, A., Bianchi, F., Dommen, J., Curtius, J., Petäjä, T., and Worsnop, D. R.: Bisulfate - cluster based atmospheric pressure chemical ionization mass spectrometer for high-sensitivity $(<100 \mathrm{ppqV})$ detection of atmospheric dimethyl amine: proof-of-concept and first ambient data from boreal forest, Atmos. Meas. Tech., 8, 4001-4011, https://doi.org/10.5194/amt-8-4001-2015, 2015.

ten Brink, H., Otjes, R., Jongejan, P., and Slanina, S.: An instrument for semi-continuous monitoring of the size-distribution of nitrate, ammonium, sulphate and chloride in aerosol, Atmos. Environ., 41, 2768-2779, https://doi.org/10.1016/j.atmosenv.2006.11.041, 2007.

US EPA: Estimation Programs Interface Suite $^{\mathrm{TM}}$ for Microsoft ${ }^{\circledR}$ Windows, v 4.11, United States Environmental Protection Agency, Washington, DC, USA, 2017.

VandenBoer, T. C., Petroff, A., Markovic, M. Z., and Murphy, J. G.: Size distribution of alkyl amines in continental particulate matter and their online detection in the gas and particle phase, Atmos. Chem. Phys., 11, 4319-4332, https://doi.org/10.5194/acp11-4319-2011, 2011.
VandenBoer, T. C., Markovic, M. Z., Petroff, A., Czar, M. F., Borduas, N., and Murphy, J. G.: Ion chromatographic separation and quantitation of alkyl methylamines and ethylamines in atmospheric gas and particulate matter using preconcentration and suppressed conductivity detection, J. Chromatogr. A, 1252, 7483, https://doi.org/10.1016/j.chroma.2012.06.062, 2012.

Vanhanen, J., Mikkilä, J., Lehtipalo, K., Sipilä, M., Manninen, H. E., Siivola, E., Petäjä, T., Kulmala, M.: Particle size magnifier for nano-CN detection, Aerosol Sci. Tech., 45, 533-542, 2011.

van Pinxteren, M., Fiedler, B., van Pinxteren, B., Iinuma, Y., Kortzinger, A., and Herrmann, H.: Chemical characterization of sub-micrometer aerosol particles in the tropical Atlantic Ocean: marine and biomass burning influences, J. Atmos. Chem., 72, 105-125, https://doi.org/10.1007/s10874-015-9307-3, 2015.

Verriele, M., Plaisance, H., Depelchin, L., Benchabane, S., Locoge, N., and Meunier, G.: Determination of 14 amines in air samples using midget impingers sampling followed by analysis with ion chromatography in tandem with mass spectrometry, J. Environ. Monitor., 14, 402-408, https://doi.org/10.1039/c2em10636a, 2012.

You, Y., Kanawade, V. P., de Gouw, J. A., Guenther, A. B., Madronich, S., Sierra-Hernández, M. R., Lawler, M., Smith, J. N., Takahama, S., Ruggeri, G., Koss, A., Olson, K., Baumann, K., Weber, R. J., Nenes, A., Guo, H., Edgerton, E. S., Porcelli, L., Brune, W. H., Goldstein, A. H., and Lee, S.-H.: Atmospheric amines and ammonia measured with a chemical ionization mass spectrometer (CIMS), Atmos. Chem. Phys., 14, 12181-12194, https://doi.org/10.5194/acp-14-12181-2014, 2014.

Youn, J.-S., Crosbie, E., Maudlin, L. C., Wang, Z., Sorooshian, A.: Dimethylamine as a major alkyl amine species in particles and cloud water: Observations in semi-arid and coastal regions, Atmos. Environ., 122, 250-258, 2015.

Zheng, J., Ma, Y., Chen, M., Zhang, Q., Wang, L., Khalizov, A. F., Yao, L., Wang, Z., Wang, X., and Chen, L.: Measurements of atmospheric amines and ammonia using the high resolution timeof-flight chemical ionization mass spectrometry, Atmos. Environ., 102, 249-259, 2015. 
Supplement of Atmos. Chem. Phys., 18, 6367-6380, 2018

https://doi.org/10.5194/acp-18-6367-2018-supplement

(C) Author(s) 2018. This work is distributed under

the Creative Commons Attribution 4.0 License.

(c) (1)

\section{Atmospheric \\ Chemistry \\ and Physics}

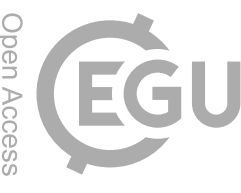

Supplement of

\section{Amines in boreal forest air at SMEAR II station in Finland}

\section{Hemmilä et al.}

Correspondence to: Marja Hemmilä (marja.hemmila@fmi.fi)

The copyright of individual parts of the supplement might differ from the CC BY 4.0 License. 
Table S1. Mean temperature and average wind speed and humidity during measurements. We have used only the data that was measured at the same time as our amine data for the calculations.

\begin{tabular}{|c|c|c|c|c|c|c|c|c|c|c|c|c|c|}
\hline \multirow[b]{2}{*}{ Month } & \multicolumn{2}{|c|}{$\begin{array}{c}\text { Temperature } \\
\left({ }^{\circ} \mathrm{C}\right)\end{array}$} & \multicolumn{2}{|c|}{$\begin{array}{l}\text { Wind speed } \\
(\mathrm{m} / \mathrm{s})\end{array}$} & \multirow[t]{2}{*}{$\begin{array}{l}\text { Main wind } \\
\text { direction }\end{array}$} & \multicolumn{2}{|c|}{$\begin{array}{l}\text { Humidity } \\
(\%)\end{array}$} & \multicolumn{2}{|c|}{$\begin{array}{l}\text { Rain } \\
(\mathrm{mm})\end{array}$} & \multicolumn{2}{|c|}{$\begin{array}{l}\text { Soil temp. } \\
\quad\left({ }^{\circ} \mathrm{C}\right)\end{array}$} & \multicolumn{2}{|c|}{$\begin{array}{l}\text { Soil humidity } \\
\qquad\left(\mathrm{m}^{3} / \mathrm{m}^{3}\right)\end{array}$} \\
\hline & Mean & StDev & Mean & StDev & & Mean & StDev & Mean & StDev & Mean & StDev & Mean & StDev \\
\hline Apr & 3.7 & 3.3 & 2.4 & 0.9 & $\mathrm{~W}$ & 75 & 20 & 0.01 & 0.07 & 2.0 & 0.9 & 0.4 & 0.02 \\
\hline May & 9.7 & 3.9 & 1.8 & 0.7 & SSE & 69 & 21 & 0.00 & 0.01 & 6.0 & 1.1 & 0.4 & 0.02 \\
\hline Jul & 13.8 & 3.1 & 1.5 & 0.5 & NW & 75 & 17 & 0.01 & 0.03 & 12.2 & 0.9 & 0.3 & 0.01 \\
\hline Nov & 2.7 & 2.1 & 2.9 & 1.0 & SSW & 95 & 3.9 & 0.04 & 0.08 & 3.2 & 0.4 & 0.2 & 0.01 \\
\hline Dec & -0.1 & 1.7 & 1.9 & 0.5 & NWW & 94 & 4.3 & 0.01 & 0.06 & 2.6 & 0.3 & 0.2 & 0.03 \\
\hline
\end{tabular}

Table S2. The settings of mass spectrometric analysis

\begin{tabular}{lll}
\hline Item & Setting & Unit \\
\hline Nebulizing Gas $\left(\mathrm{N}_{2}\right)$ Flow & 1.5 & $1 \mathrm{~min}^{-1}$ \\
DL Temperature & 210 & ${ }^{\circ} \mathrm{C}$ \\
Heat Block Temperature & 400 & ${ }^{\circ} \mathrm{C}$ \\
Detector Voltage & 1.25 & $\mathrm{kV}$ \\
IG Vaguum & $9.8^{*} 10^{-4}$ & $\mathrm{~Pa}$ \\
PG Vacuum & $5.4^{*} 10^{4}$ & $\mathrm{~Pa}$
\end{tabular}


Table S3. Monthly mean and median (med.) of gas and aerosol phase amines and ammonia. $\mathrm{N}$ is number of data points.

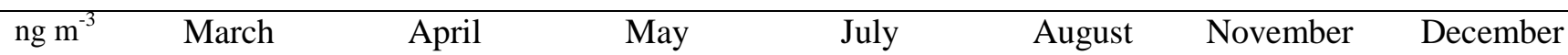
mean med. mean med. mean med. mean med. mean med. mean med. mean med

$\underline{\text { Gas }}$

$\underline{\mathrm{N}}$

117

112

163

91

113

128

54

DEA $<\mathrm{DL}<\mathrm{DL}<\mathrm{DL}<\mathrm{DL}<\mathrm{DL}<\mathrm{DL}<\mathrm{DL}<\mathrm{DL}<\mathrm{DL}<\mathrm{DL}<\mathrm{DL}<\mathrm{DL}<\mathrm{DL}<\mathrm{DL}$

$\mathrm{BA}<\mathrm{DL}<\mathrm{DL}<\mathrm{DL}<\mathrm{DL}<\mathrm{DL}<\mathrm{DL}<\mathrm{DL}<\mathrm{DL}<\mathrm{DL}<\mathrm{DL}<\mathrm{DL}<\mathrm{DL}<\mathrm{DL}<\mathrm{DL}$

DMA $<\mathrm{DL}<\mathrm{DL}<\mathrm{DL}<\mathrm{DL}<\mathrm{DL}<\mathrm{DL}<\mathrm{DL}<\mathrm{DL}<\mathrm{DL}<\mathrm{DL}<\mathrm{DL}<\mathrm{DL}<\mathrm{DL}<\mathrm{DL}$

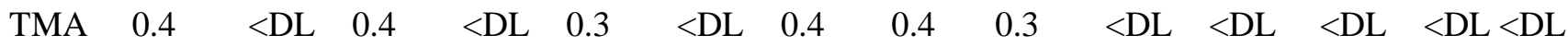

$\mathrm{PA}<\mathrm{DL}<\mathrm{DL}<\mathrm{DL}<\mathrm{DL}<\mathrm{DL}<\mathrm{DL}<\mathrm{DL}<\mathrm{DL}<\mathrm{DL}<\mathrm{DL}<\mathrm{DL}<\mathrm{DL}<\mathrm{DL}<\mathrm{DL}$

$\mathrm{EA}<\mathrm{DL}<\mathrm{DL}<\mathrm{DL}<\mathrm{DL}<\mathrm{DL}<\mathrm{DL}<\mathrm{DL}<\mathrm{DL}<\mathrm{DL}<\mathrm{DL}<\mathrm{DL}<\mathrm{DL}<\mathrm{DL}<\mathrm{DL}$

$\mathrm{MMA}<\mathrm{DL}<\mathrm{DL}<\mathrm{DL}<\mathrm{DL}<\mathrm{DL}<\mathrm{DL}<\mathrm{DL}<\mathrm{DL}<\mathrm{DL}<\mathrm{DL}<\mathrm{DL}<\mathrm{DL}<\mathrm{DL}<\mathrm{DL}$

$\begin{array}{llllllllllll}\mathrm{NH}_{3} & 52 & 19 & 52 & <\mathrm{DL} & 81 & 22 & 45 & <\mathrm{DL} & 66 & <\mathrm{DL} & <\mathrm{DL}\end{array}<\mathrm{DL} \quad<\mathrm{DL}<\mathrm{DL}$

Aerosol

$\underline{\mathrm{N}}-117$

112

163

91

113

128

54

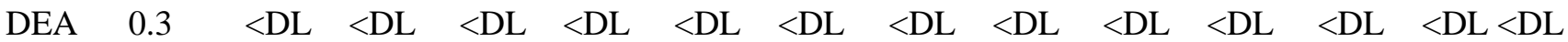

$\mathrm{BA}<\mathrm{DL}<\mathrm{DL}<\mathrm{DL}<\mathrm{DL}<\mathrm{DL}<\mathrm{DL}<\mathrm{DL}<\mathrm{DL}<\mathrm{DL}<\mathrm{DL}<\mathrm{DL}<\mathrm{DL}<\mathrm{DL}<\mathrm{DL}$

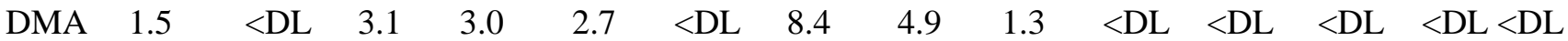

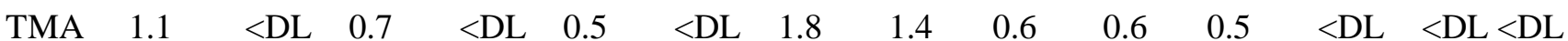

$\mathrm{PA}<\mathrm{DL}<\mathrm{DL}<\mathrm{DL}<\mathrm{DL}<\mathrm{DL}<\mathrm{DL}<\mathrm{DL}<\mathrm{DL}<\mathrm{DL}<\mathrm{DL}<\mathrm{DL}<\mathrm{DL}<\mathrm{DL}<\mathrm{DL}$

EA $\quad<D L \quad<D L \quad<D L \quad<D L \quad<D L \quad<D L \quad 0.4 \quad<D L \quad<D L \quad<D L \quad<D L \quad<D L \quad<D L<D L$

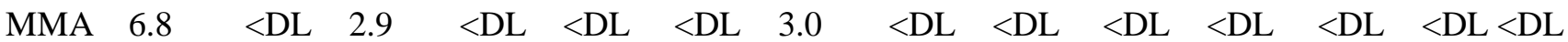

$\begin{array}{lllllllllllllll}\mathrm{NH}_{4}{ }^{+} & 425 & 90 & 144 & 64 & 145 & 97 & 136 & 92 & 88 & 28 & 85 & 18 & 8.4 & <\mathrm{DL}\end{array}$ 
Table S4. Regression statistics $\left(y=\beta_{1} x+\beta_{0}\right)$ of amine and ammonia concentrations in the gas phase vs. ambient conditions. $\mathrm{R}^{2}$ : the square of the Pearson's correlation coefficient; s.e.: standard error of $\beta_{1}$; d.f.: degrees of freedom; $t=\beta_{1}$ /s.e.; $p$ : $p$-value of the Student's $t$ distribution; air T: air temperature; RH: relative humidity of air; WS: wind speed at $16.8 \mathrm{~m}$; soil T: soil temperature; soil Hum: soil humidity. The slopes, standard errors and $t$-values are shown only for those regressions that have a $\mathrm{p}$ value $<0.1$. Very low $\mathrm{p}-$ values are highlighted by bold font.

\begin{tabular}{|c|c|c|c|c|c|c|c|}
\hline $\mathrm{x}$ & $\mathrm{y}$ & $\mathrm{R}^{2}$ & $\beta_{1}$ & \pm s.e. & d.f. & $\mathrm{t}$ & $\mathrm{p}$ \\
\hline $\begin{array}{l}\text { air T } \\
\text { RH } \\
\text { WS } \\
\text { soil T } \\
\text { soil Hum }\end{array}$ & $\begin{array}{l}\text { MMA(g) } \\
\text { MMA(g) } \\
\text { MMA(g) } \\
\text { MMA(g) } \\
\text { MMA(g) }\end{array}$ & $\begin{array}{l}0.01 \\
0.16 \\
0.17 \\
0.00 \\
0.00\end{array}$ & & & $\begin{array}{l}11 \\
11 \\
11 \\
21 \\
19\end{array}$ & & $\begin{array}{l}0.82 \\
0.17 \\
0.16 \\
0.94 \\
0.85\end{array}$ \\
\hline $\begin{array}{l}\text { air T } \\
\text { RH } \\
\text { WS } \\
\text { soil T } \\
\text { soil Hum }\end{array}$ & $\begin{array}{l}\operatorname{DMA}(\mathrm{g}) \\
\operatorname{DMA}(\mathrm{g}) \\
\operatorname{DMA}(\mathrm{g}) \\
\operatorname{DMA}(\mathrm{g}) \\
\operatorname{DMA}(\mathrm{g})\end{array}$ & $\begin{array}{l}0.55 \\
0.36 \\
0.30 \\
0.31 \\
0.63\end{array}$ & $\begin{array}{l}0.29 \\
-0.071 \\
-0.99 \\
0.28 \\
25\end{array}$ & $\begin{array}{l} \pm 0.03 \\
\pm 0.009 \\
\pm 0.15 \\
\pm 0.04 \\
\pm 2\end{array}$ & $\begin{array}{l}106 \\
106 \\
106 \\
115 \\
113\end{array}$ & $\begin{array}{l}11.4 \\
-7.7 \\
-6.8 \\
7.2 \\
13.9\end{array}$ & $\begin{array}{l}4.4 \mathrm{E}-20 \\
7.6 \mathrm{E}-12 \\
6.3 \mathrm{E}-10 \\
6.2 \mathrm{E}-11 \\
3.7 \mathrm{E}-26\end{array}$ \\
\hline $\begin{array}{l}\text { air T } \\
\text { RH } \\
\text { WS } \\
\text { soil T } \\
\text { soil Hum }\end{array}$ & $\begin{array}{l}\mathrm{EA}(\mathrm{g}) \\
\mathrm{EA}(\mathrm{g}) \\
\mathrm{EA}(\mathrm{g}) \\
\mathrm{EA}(\mathrm{g}) \\
\mathrm{EA}(\mathrm{g})\end{array}$ & $\begin{array}{l}0.08 \\
0.00 \\
0.02 \\
0.12 \\
0.11\end{array}$ & $\begin{array}{l}-0.12 \\
9\end{array}$ & $\begin{array}{l} \\
\pm 0.04 \\
\pm 4\end{array}$ & $\begin{array}{l}49 \\
49 \\
49 \\
57 \\
54\end{array}$ & $\begin{array}{l}-2.8 \\
2.6\end{array}$ & $\begin{array}{l}0.051 \\
0.83 \\
0.38 \\
0.0064 \\
0.013\end{array}$ \\
\hline $\begin{array}{l}\text { air T } \\
\text { RH } \\
\text { WS } \\
\text { soil T } \\
\text { soil Hum }\end{array}$ & $\begin{array}{l}\text { TMA }(g) \\
\text { TMA }(g) \\
\text { TMA }(g) \\
\text { TMA }(g) \\
\text { TMA }(g)\end{array}$ & $\begin{array}{l}0.06 \\
0.01 \\
0.01 \\
0.06 \\
0.09\end{array}$ & $\begin{array}{l}-0.05 \\
5.1\end{array}$ & $\begin{array}{l} \pm 0.009 \\
\pm 0.01 \\
\pm 1.0\end{array}$ & $\begin{array}{l}297 \\
297 \\
297 \\
309 \\
297\end{array}$ & $\begin{array}{l}-4.5 \\
5.3\end{array}$ & $\begin{array}{l}\text { 3.3E-05 } \\
0.18 \\
0.038 \\
\text { 1.2E-05 } \\
\text { 2.3E-07 }\end{array}$ \\
\hline $\begin{array}{l}\text { air T } \\
\text { RH } \\
\text { WS } \\
\text { soil T } \\
\text { soil Hum }\end{array}$ & $\begin{array}{l}\mathrm{PA}(\mathrm{g}) \\
\mathrm{PA}(\mathrm{g}) \\
\mathrm{PA}(\mathrm{g}) \\
\mathrm{PA}(\mathrm{g}) \\
\mathrm{PA}(\mathrm{g})\end{array}$ & $\begin{array}{l}0.02 \\
0.11 \\
0.00 \\
0.00 \\
0.12\end{array}$ & & & $\begin{array}{l}12 \\
12 \\
12 \\
18 \\
12\end{array}$ & & $\begin{array}{l}0.66 \\
0.25 \\
0.84 \\
0.91 \\
0.22\end{array}$ \\
\hline $\begin{array}{l}\text { air T } \\
\text { RH } \\
\text { WS } \\
\text { soil T } \\
\text { soil Hum }\end{array}$ & $\begin{array}{l}\operatorname{DEA}(g) \\
\operatorname{DEA}(g) \\
\operatorname{DEA}(g) \\
\operatorname{DEA}(g) \\
\operatorname{DEA}(g)\end{array}$ & $\begin{array}{l}0.00 \\
0.00 \\
0.03 \\
0.04 \\
0.04\end{array}$ & -0.07 & \pm 0.04 & $\begin{array}{l}79 \\
78 \\
79 \\
79 \\
67\end{array}$ & -1.9 & $\begin{array}{l}0.67 \\
0.57 \\
0.10 \\
0.066 \\
0.11\end{array}$ \\
\hline $\begin{array}{l}\text { air T } \\
\text { RH } \\
\text { WS } \\
\text { soil T } \\
\text { soil Hum }\end{array}$ & $\begin{array}{l}\mathrm{BA}(\mathrm{g}) \\
\mathrm{BA}(\mathrm{g}) \\
\mathrm{BA}(\mathrm{g}) \\
\mathrm{BA}(\mathrm{g}) \\
\mathrm{BA}(\mathrm{g})\end{array}$ & $\begin{array}{l}0.11 \\
0.05 \\
0.04 \\
0.11 \\
0.17\end{array}$ & $\begin{array}{l}-0.006 \\
-0.009 \\
1.1\end{array}$ & \pm 0.003 & $\begin{array}{l}29 \\
29 \\
29 \\
31 \\
28\end{array}$ & $\begin{array}{l}-2.0 \\
2.4\end{array}$ & $\begin{array}{l}0.07 \\
0.24 \\
0.31 \\
0.056 \\
0.024\end{array}$ \\
\hline $\begin{array}{l}\text { air T } \\
\text { RH } \\
\text { WS } \\
\text { soil T } \\
\text { soil Hum } \\
\end{array}$ & $\begin{array}{l}\mathrm{NH}_{3} \\
\mathrm{NH}_{3} \\
\mathrm{NH}_{3} \\
\mathrm{NH}_{3} \\
\mathrm{NH}_{3} \\
\end{array}$ & $\begin{array}{l}0.07 \\
0.04 \\
0.00 \\
0.01 \\
0.00 \\
\end{array}$ & $\begin{array}{l}0.00142 \\
-0.00040\end{array}$ & $\begin{array}{l} \pm 0.00023 \\
\pm 0.00008 \\
\pm 0.00029\end{array}$ & $\begin{array}{l}527 \\
527 \\
527 \\
605 \\
541 \\
\end{array}$ & $\begin{array}{l}6.3 \\
-4.9\end{array}$ & $\begin{array}{l}\text { 6.8E-10 } \\
\mathbf{1 . 3 E}-06 \\
0.39 \\
0.010 \\
0.60 \\
\end{array}$ \\
\hline
\end{tabular}


Table S5. Regression statistics $\left(y=\beta_{1} \mathrm{x}+\beta_{0}\right)$ of amine concentrations in the aerosol phase vs. ambient conditions. Detailed column description as in Table S4.

\begin{tabular}{|c|c|c|c|c|c|c|}
\hline $\mathrm{x}$ & $\mathrm{y}$ & $\mathrm{R}^{2}$ & $\beta_{1} \pm$ s.e. & d.f. & $\mathrm{t}$ & $\mathrm{p}$ \\
\hline air T & MMA(a) & 0.10 & $-0.42 \pm 0.08$ & 235 & -5.2 & 3.5E-07 \\
\hline RH & MMA(a) & 0.09 & $0.11 \pm 0.02$ & 235 & 4.8 & 2.7E-06 \\
\hline WS & MMA(a) & 0.05 & $1.8 \pm 0.5$ & 235 & 3.6 & 4.2E-04 \\
\hline soil T & MMA(a) & 0.10 & $-0.47 \pm 0.09$ & 248 & -5.3 & 2.6E-07 \\
\hline soil Hum & MMA(a) & 0.05 & $26 \pm 8$ & 226 & 3.3 & 0.0012 \\
\hline air $\mathrm{T}$ & DMA(a) & 0.04 & $0.12 \pm 0.03$ & 486 & 4.3 & 2.4E-05 \\
\hline RH & DMA(a) & 0.02 & & 486 & & 0.0020 \\
\hline WS & DMA(a) & 0.03 & $-0.9 \pm 0.2$ & 486 & -3.9 & $1.2 \mathrm{E}-04$ \\
\hline soil T & DMA(a) & 0.04 & $0.17 \pm 0.04$ & 521 & 4.6 & 4.6E-06 \\
\hline soil Hum & DMA(a) & 0.00 & & 487 & & 0.15 \\
\hline air T & $\mathrm{EA}(\mathrm{a})$ & 0.11 & $-0.055 \pm 0.02$ & 70 & -3.0 & 0.0040 \\
\hline RH & $\mathrm{EA}(\mathrm{a})$ & 0.03 & & 70 & & 0.14 \\
\hline WS & EA(a) & 0.07 & $0.4 \pm 0.2$ & 70 & 2.2 & 0.030 \\
\hline soil $\mathrm{T}$ & EA(a) & 0.06 & $-0.12 \pm 0.05$ & 75 & -2.2 & 0.029 \\
\hline soil Hum & $\mathrm{EA}(\mathrm{a})$ & 0.16 & $18 \pm 5$ & 66 & 3.6 & $5.9 \mathrm{E}-04$ \\
\hline air T & TMA(a) & 0.01 & $-0.03 \pm 0.01$ & 372 & -2.3 & 0.019 \\
\hline RH & TMA(a) & 0.00 & & 372 & & 0.90 \\
\hline WS & TMA(a) & 0.00 & & 372 & & 0.85 \\
\hline soil $\mathrm{T}$ & TMA(a) & 0.01 & & 383 & & 0.028 \\
\hline soil Hum & TMA(a) & 0.09 & $5.5 \pm 1.0$ & 342 & 5.8 & 1.7E-08 \\
\hline air $\mathrm{T}$ & PA(a) & 0.01 & & 24 & & 0.64 \\
\hline RH & PA(a) & 0.01 & & 24 & & 0.67 \\
\hline WS & $\mathrm{PA}(\mathrm{a})$ & 0.01 & & 24 & & 0.57 \\
\hline soil $\mathrm{T}$ & $\mathrm{PA}(\mathrm{a})$ & 0.05 & & 28 & & 0.24 \\
\hline soil Hum & PA(a) & 0.10 & & 19 & & 0.16 \\
\hline air $\mathrm{T}$ & DEA(a) & 0.18 & $-0.05 \pm 0.02$ & 22 & -2.2 & 0.038 \\
\hline $\mathrm{RH}$ & DEA(a) & 0.09 & & 22 & & 0.15 \\
\hline WS & DEA(a) & 0.07 & & 22 & & 0.22 \\
\hline soil T & DEA(a) & 0.18 & $-0.07 \pm 0.03$ & 24 & -2.3 & 0.028 \\
\hline soil Hum & DEA(a) & 0.03 & & 18 & & 0.47 \\
\hline air $\mathrm{T}$ & $\mathrm{BA}(\mathrm{a})$ & 0.24 & $-0.020 \pm 0.008$ & 18 & -2.4 & 0.028 \\
\hline RH & $\mathrm{BA}(\mathrm{a})$ & 0.08 & & 18 & & 0.23 \\
\hline WS & $\mathrm{BA}(\mathrm{a})$ & 0.02 & & 18 & & 0.58 \\
\hline soil T & $\mathrm{BA}(\mathrm{a})$ & 0.21 & $-0.03 \pm 0.01$ & 19 & -2.2 & 0.038 \\
\hline soil Hum & $\mathrm{BA}(\mathrm{a})$ & 0.07 & & 14 & & 0.32 \\
\hline air $\mathrm{T}$ & $\mathrm{NH}_{4}^{+}$ & 0.0382 & $-0.007 \pm 0.001$ & 654 & -5.1 & 4.5E-07 \\
\hline $\mathrm{RH}$ & $\mathrm{NH}_{4}^{+}$ & 0.0610 & $0.0031 \pm 0.0005$ & 654 & 6.5 & $1.4 \mathrm{E}-10$ \\
\hline WS & $\mathrm{NH}_{4}^{+}$ & 0.0355 & $0.055 \pm 0.011$ & 654 & 4.9 & $1.2 \mathrm{E}-06$ \\
\hline soil T & $\mathrm{NH}_{4}^{+}$ & 0.0665 & $-0.012 \pm 0.002$ & 732 & -7.2 & $1.3 \mathrm{E}-12$ \\
\hline soil Hum & $\mathrm{NH}_{4}^{+}$ & 0.0221 & $0.58 \pm 0.15$ & 668 & 3.9 & $1.1 E-04$ \\
\hline
\end{tabular}


Table S6. Regression statistics $\left(y=\beta_{1} x+\beta_{0}\right)$ of aerosol number concentrations vs. amine and ammonia concentrations in the gas phase. Detailed column description as in Table 5. $\mathrm{N}_{\text {tot }}$ : aerosol number concentration integrated from the size distributions measured with the DMPS; $\mathrm{N}_{1.1-2 \mathrm{~nm}}$ and $\mathrm{N}_{2-3 \mathrm{~nm}}$ : aerosol number concentrations in the size ranges $1.2-2 \mathrm{~nm}$ and $2-3 \mathrm{~nm}$, measured with the PSM; $\mathrm{N}_{3-25 \mathrm{~nm}}$ : aerosol number concentrations between 3 and $25 \mathrm{~nm}$ of the DMPS. The line of DMA $(\mathrm{g})$ (* was calculated by using only those data that were measured when $\mathrm{RH}>90 \%$.

\begin{tabular}{|c|c|c|c|c|c|c|}
\hline $\mathrm{x}$ & $\mathrm{y}$ & $\mathrm{R}^{2}$ & $\beta_{1} \pm$ s.e. & d.f. & $\mathrm{t}$ & $\mathrm{p}$ \\
\hline $\operatorname{MMA}(\mathrm{g})$ & $\mathrm{N}_{\text {tot }}$ & 0.11 & & 21 & & 0.12 \\
\hline $\operatorname{MMA}(\mathrm{g})$ & $\mathrm{N}_{1.1-2 \mathrm{~nm}}$ & & & 0 & & \\
\hline $\operatorname{MMA}(\mathrm{g})$ & $\mathrm{N}_{2-3 \mathrm{~nm}}$ & & & 0 & & \\
\hline $\operatorname{MMA}(\mathrm{g})$ & $\mathrm{N}_{3-25 \mathrm{~nm}}$ & 0.13 & $145 \pm 83$ & 21 & 1.7 & 0.097 \\
\hline $\operatorname{DMA}(\mathrm{g})$ & $\mathrm{N}_{\text {tot }}$ & 0.16 & $222 \pm 47$ & 115 & 4.7 & $6.1 \mathrm{E}-06$ \\
\hline DMA $(\mathrm{g})$ & $\mathrm{N}_{1.1-2 \mathrm{~nm}}$ & 0.06 & $229 \pm 166$ & 31 & 1.4 & 0.18 \\
\hline$D M A(\mathrm{~g}){ }^{*}$ & $N_{l .1-2 \mathrm{~nm}}$ & 0.63 & $481 \pm 130$ & 8 & 3.7 & 0.0061 \\
\hline $\mathrm{DMA}(\mathrm{g})$ & $\mathrm{N}_{2-3 \mathrm{~nm}}$ & 0.00 & & 34 & & 0.95 \\
\hline $\operatorname{DMA}(\mathrm{g})$ & $\mathrm{N}_{3-25 \mathrm{~nm}}$ & 0.04 & $58 \pm 27$ & 115 & 2.1 & 0.034 \\
\hline $\mathrm{EA}(\mathrm{g})$ & $\mathrm{N}_{\text {tot }}$ & 0.01 & & 57 & & 0.58 \\
\hline $\mathrm{EA}(\mathrm{g})$ & $\mathrm{N}_{1.1-2 \mathrm{~nm}}$ & 0.05 & & 41 & & 0.16 \\
\hline $\mathrm{EA}(\mathrm{g})$ & $\mathrm{N}_{2-3 \mathrm{~nm}}$ & 0.07 & $-80 \pm 44$ & 43 & -1.8 & 0.08 \\
\hline $\mathrm{EA}(\mathrm{g})$ & $\mathrm{N}_{3-25 \mathrm{~nm}}$ & 0.03 & & 57 & & 0.23 \\
\hline TMA(g) & $\mathrm{N}_{\text {tot }}$ & 0.00 & & 309 & & 0.23 \\
\hline TMA $(\mathrm{g})$ & $\mathrm{N}_{1.1-2 \mathrm{~nm}}$ & 0.01 & & 187 & & 0.12 \\
\hline TMA(g) & $\mathrm{N}_{2-3 \mathrm{~nm}}$ & 0.00 & & 207 & & 0.58 \\
\hline TMA $(\mathrm{g})$ & $\mathrm{N}_{3-25 \mathrm{~nm}}$ & 0.00 & & 309 & & 0.66 \\
\hline $\mathrm{PA}(\mathrm{g})$ & $\mathrm{N}_{\text {tot }}$ & 0.03 & & 18 & & 0.45 \\
\hline $\mathrm{PA}(\mathrm{g})$ & $\mathrm{N}_{1.1-2 \mathrm{~nm}}$ & 0.18 & & 3 & & 0.48 \\
\hline $\mathrm{PA}(\mathrm{g})$ & $\mathrm{N}_{2-3 \mathrm{~nm}}$ & 0.01 & & 6 & & 0.84 \\
\hline PA(g) & $\mathrm{N}_{3-25 \mathrm{~nm}}$ & 0.04 & & 18 & & 0.40 \\
\hline $\mathrm{DEA}(\mathrm{g})$ & $\mathrm{N}_{\text {tot }}$ & 0.00 & & 73 & & 0.96 \\
\hline $\mathrm{DEA}(\mathrm{g})$ & $\mathrm{N}_{1.1-2 \mathrm{~nm}}$ & & & 1 & & \\
\hline $\mathrm{DEA}(\mathrm{g})$ & $\mathrm{N}_{2-3 \mathrm{~nm}}$ & & & 1 & & \\
\hline $\operatorname{DEA}(\mathrm{g})$ & $\mathrm{N}_{3-25 \mathrm{~nm}}$ & 0.00 & & 79 & & 0.59 \\
\hline $\mathrm{BA}(\mathrm{g})$ & $\mathrm{N}_{\text {tot }}$ & 0.10 & $2234 \pm 1230$ & 31 & 1.8 & 0.08 \\
\hline $\mathrm{BA}(\mathrm{g})$ & $\mathrm{N}_{1.1-2 \mathrm{~nm}}$ & 0.01 & & 16 & & 0.74 \\
\hline $\mathrm{BA}(\mathrm{g})$ & $\mathrm{N}_{2-3 \mathrm{~nm}}$ & 0.16 & & 17 & & 0.09 \\
\hline $\mathrm{BA}(\mathrm{g})$ & $\mathrm{N}_{3-25 \mathrm{~nm}}$ & 0.01 & & 31 & & 0.63 \\
\hline $\mathrm{NH}_{3}$ & $\mathrm{~N}_{\text {tot }}$ & 0.00 & & 605 & & 0.93 \\
\hline $\mathrm{NH}_{3}$ & $\mathrm{~N}_{1.1-2 \mathrm{~nm}}$ & 0.13 & $10853 \pm 1710$ & 272 & 6.3 & 9.1E-10 \\
\hline $\mathrm{NH}_{3}$ & $\mathrm{~N}_{2-3 \mathrm{~nm}}$ & 0.03 & $2154 \pm 656$ & 336 & 3.3 & 0.0011 \\
\hline $\mathrm{NH}_{3}$ & $\mathrm{~N}_{3-25 \mathrm{~nm}}$ & 0.00 & & 605 & & 0.33 \\
\hline
\end{tabular}


Table S7. Regression statistics $\left(y=\beta_{1} x+\beta_{0}\right)$ of aerosol number concentrations vs. amine concentrations in the aerosol phase. Detailed column description as in Tables S4 - S6. The line of DMA(a) (* was calculated by using only those data that were measured when $\mathrm{RH}>90 \%$.

\begin{tabular}{|c|c|c|c|c|c|c|}
\hline $\mathrm{x}$ & $\mathrm{y}$ & $\mathrm{R}^{2}$ & $\beta_{1} \pm$ s.e. & d.f. & $\mathrm{t}$ & $\mathrm{p}$ \\
\hline MMA(a) & $\mathrm{N}_{\text {tot }}$ & 0.04 & $53 \pm 15$ & 248 & 3.4 & $7.9 \mathrm{E}-04$ \\
\hline MMA(a) & $\mathrm{N}_{1.1-2 \mathrm{~nm}}$ & 0.05 & $-335 \pm 159$ & 77 & -2.1 & 0.038 \\
\hline MMA(a) & $\mathrm{N}_{2-3 \mathrm{~nm}}$ & 0.03 & & 77 & & 0.16 \\
\hline MMA(a) & $\mathrm{N}_{3-25 \mathrm{~nm}}$ & 0.02 & & 247 & & 0.019 \\
\hline DMA(a) & $\mathrm{N}_{\text {tot }}$ & 0.00 & & 521 & & 0.48 \\
\hline $\operatorname{DMA}(\mathrm{a})$ & $\mathrm{N}_{1.1-2 \mathrm{~nm}}$ & 0.10 & $99 \pm 20$ & 215 & 4.9 & $1.8 \mathrm{E}-06$ \\
\hline$D M A(a)(*$ & $N_{l .1-2 n m}$ & 0.14 & $59 \pm 23$ & 43 & 2.6 & 0.013 \\
\hline DMA(a) & $\mathrm{N}_{2-3 \mathrm{~nm}}$ & 0.00 & & 217 & & 0.93 \\
\hline DMA(a) & $\mathrm{N}_{3-25 \mathrm{~nm}}$ & 0.00 & & 519 & & 0.21 \\
\hline EA(a) & $\mathrm{N}_{\text {tot }}$ & 0.01 & & 75 & & 0.42 \\
\hline EA(a) & $\mathrm{N}_{1.1-2 \mathrm{~nm}}$ & 0.03 & & 46 & & 0.22 \\
\hline EA(a) & $\mathrm{N}_{2-3 \mathrm{~nm}}$ & 0.01 & & 37 & & 0.51 \\
\hline EA(a) & $\mathrm{N}_{3-25 \mathrm{~nm}}$ & 0.32 & $103 \pm 17$ & 75 & 6.0 & 7.1E-08 \\
\hline TMA(a) & $\mathrm{N}_{\text {tot }}$ & 0.00 & & 383 & & 0.91 \\
\hline TMA(a) & $\mathrm{N}_{1.1-2 \mathrm{~nm}}$ & 0.00 & & 232 & & 0.75 \\
\hline TMA(a) & $\mathrm{N}_{2-3 \mathrm{~nm}}$ & 0.00 & & 204 & & 0.32 \\
\hline TMA(a) & $\mathrm{N}_{3-25 \mathrm{~nm}}$ & 0.00 & & 382 & & 0.74 \\
\hline $\mathrm{PA}(\mathrm{a})$ & $\mathrm{N}_{\text {tot }}$ & 0.00 & & 28 & & 0.93 \\
\hline PA(a) & $\mathrm{N}_{1.1-2 \mathrm{~nm}}$ & & & 1 & & \\
\hline PA(a) & $\mathrm{N}_{2-3 \mathrm{~nm}}$ & & & 0 & & \\
\hline PA(a) & $\mathrm{N}_{3-25 \mathrm{~nm}}$ & 0.01 & & 28 & & 0.53 \\
\hline DEA(a) & $\mathrm{N}_{\text {tot }}$ & 0.02 & & 24 & & 0.47 \\
\hline DEA(a) & $\mathrm{N}_{1.1-2 \mathrm{~nm}}$ & & & 1 & & \\
\hline DEA(a) & $\mathrm{N}_{2-3 \mathrm{~nm}}$ & & & 1 & & \\
\hline DEA(a) & $\mathrm{N}_{3-25 \mathrm{~nm}}$ & 0.02 & & 24 & & 0.54 \\
\hline $\mathrm{BA}(\mathrm{a})$ & $\mathrm{N}_{\text {tot }}$ & 0.03 & & 19 & & 0.44 \\
\hline $\mathrm{BA}(\mathrm{a})$ & $\mathrm{N}_{1.1-2 \mathrm{~nm}}$ & & & 4 & & \\
\hline $\mathrm{BA}(\mathrm{a})$ & $\mathrm{N}_{2-3 \mathrm{~nm}}$ & & & 2 & & \\
\hline $\mathrm{BA}(\mathrm{a})$ & $\mathrm{N}_{3-25 \mathrm{~nm}}$ & 0.00 & & 19 & & 0.80 \\
\hline $\mathrm{NH}_{4}^{+}$ & $\mathrm{N}_{\text {tot }}$ & 0.04 & $1194 \pm 224$ & 732 & 5.3 & 1.3E-07 \\
\hline $\mathrm{NH}_{4}^{+}$ & $\mathrm{N}_{1.1-2 \mathrm{~nm}}$ & 0.00 & & & & 0.99 \\
\hline $\mathrm{NH}_{4}^{+}$ & $\mathrm{N}_{2-3 \mathrm{~nm}}$ & 0.00 & & & & 0.40 \\
\hline $\mathrm{NH}_{4}^{+}$ & $\mathrm{N}_{3-25 \mathrm{~nm}}$ & 0.03 & $-703 \pm 147$ & 732 & -4.8 & 2.12-06 \\
\hline
\end{tabular}




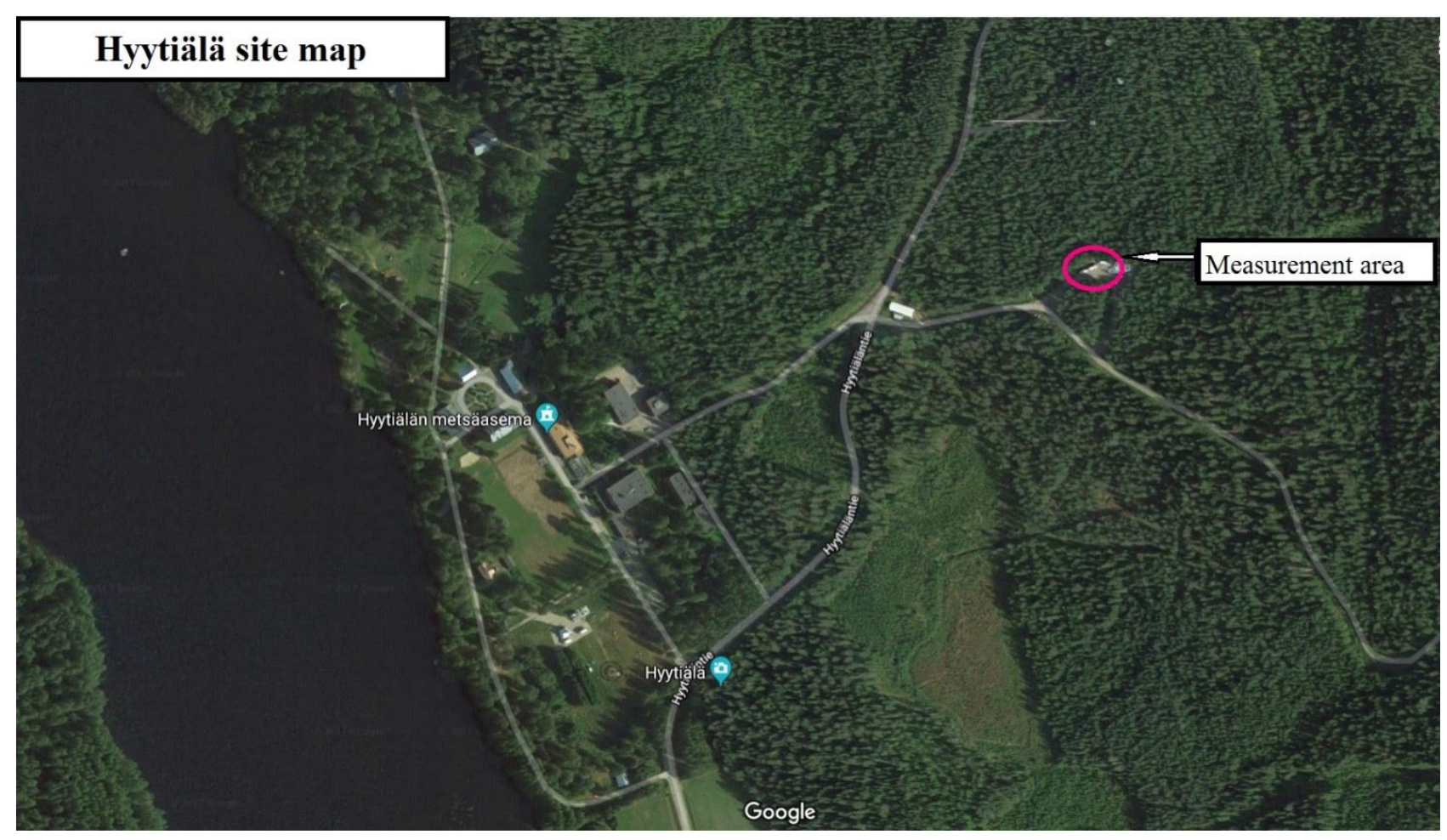

Figure S1. Hyytiälä site map. Imagery @2017 Google, Map data @2017 Google.

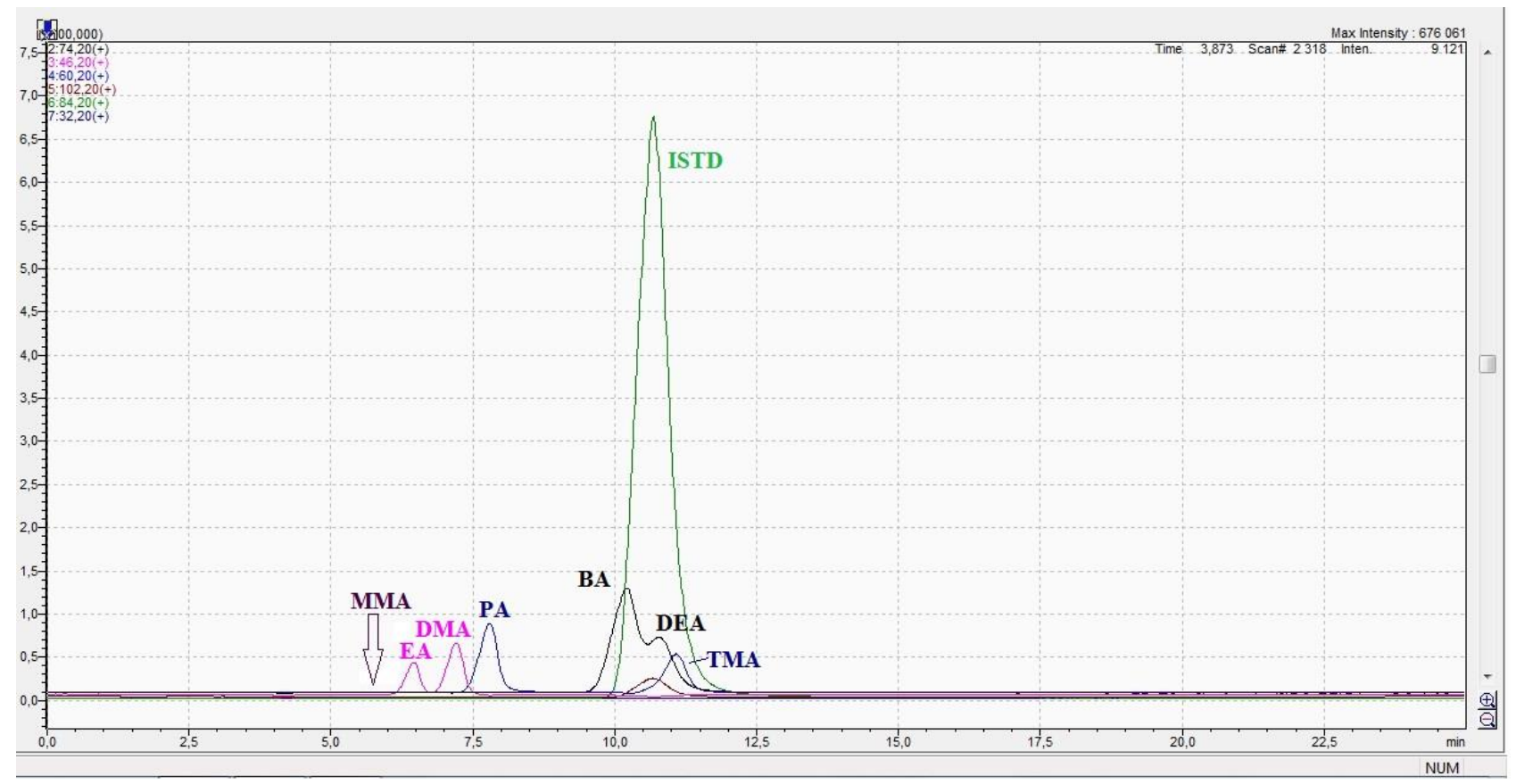

Figure S2. The chromatogram of standard level $50 \mathrm{ng} \mathrm{m}^{-3}$. Other amines than BA and DEA are separating well. Mass 84.20 is the internal standard (ISTD), deuterated diethyl-d10-amine. We were originally also developing method for triethylamine (mass 102.20), but we could not see it. In this chromatogram mass 102.20 is an impurity. 


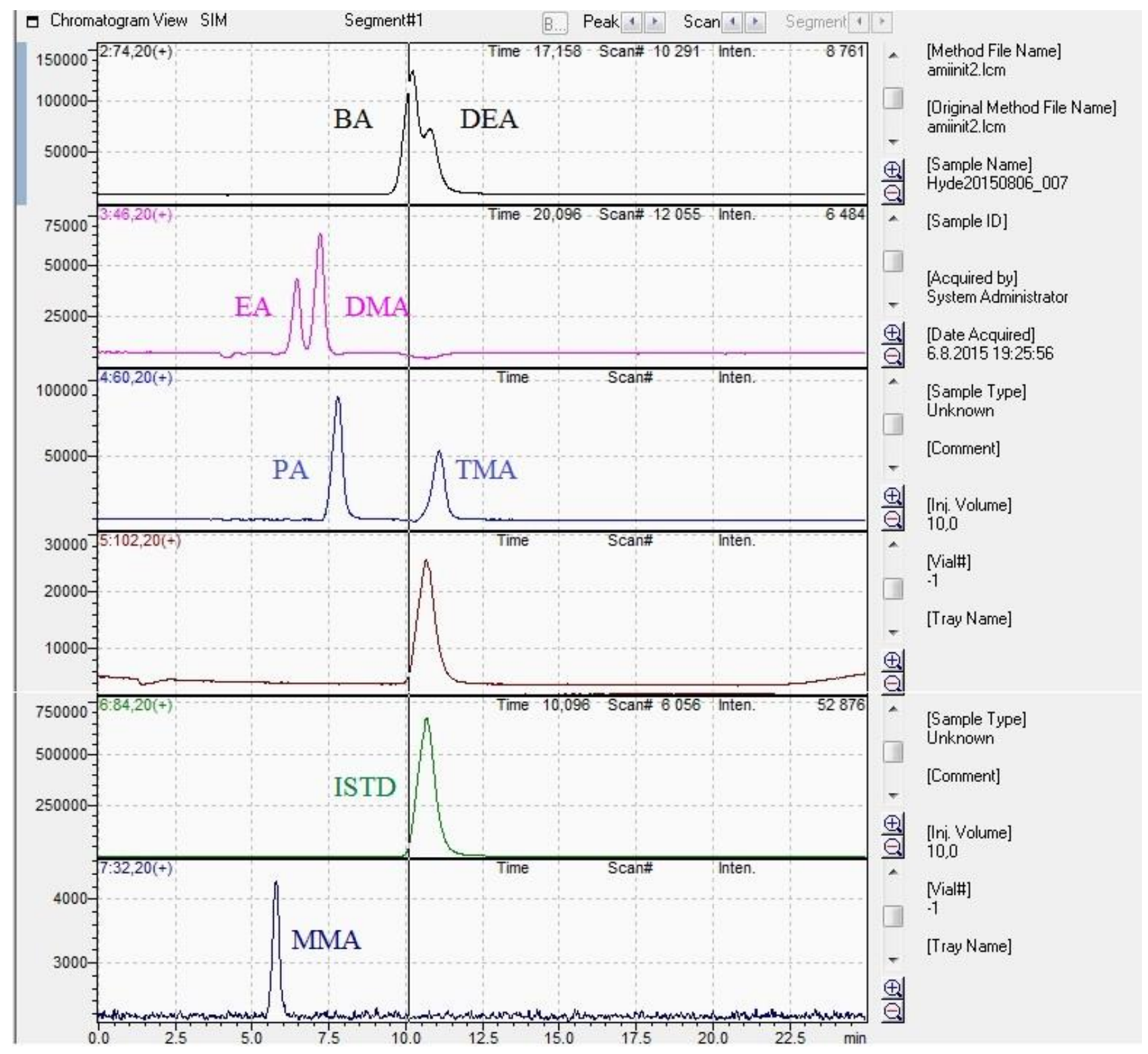

Figure S3. The same chromatogram than in Fig. S2, but different masses are separated.

\section{Particle collection in the denuder of the MARGA}

Theoretical calculations of diffusional losses through an annular tube have been derived, e.g., by Winiwarter (1989). The numerical solution of the diffusional losses in an annular denuder presented by Fan et al. (1996) and Baron and Willeke (2001) were applied to calculate the size-dependent penetration in the denuder of the MARGA. The calculation needs as input the diameter of the inner and outer tubes $(36.4 \mathrm{~mm}$ and $39.9 \mathrm{~mm}$, respectively), the tube length $26.5 \mathrm{~cm}$ and the flow rate $16.7 \mathrm{LPM}$.

The result of the calculation (Fig. S4) shows that 50\% of particles smaller than about $6 \mathrm{~nm}$ are collected in the denuder and get interpreted as gas-phase compounds. It also shows that essentially all particles larger 
than about $20 \mathrm{~nm}$ get transported through the denuder and finally get interpreted correctly as particles. The cluster-mode particles are smaller than $2 \mathrm{~nm}$ and behave primarily like gases and more than $~ 80 \%$ of them do not penetrate the denuder, whereas more than $\sim 85 \%$ of particles larger than $10 \mathrm{~nm}$ go through it. The size of nucleation-mode particles is approximately between $2-10 \mathrm{~nm}$, or up to $\sim 25 \mathrm{~nm}$, depending on the definition of the size ranges, and they appear in the atmosphere mainly during NPF events. During these events they could be found both in the denuder and in the steam-jet aerosol collector, but that does not play an essential role because of their small mass even when the number concentration is high. An estimate of the masses involved can be given by assuming that the number concentration in a nucleation mode is $10000 \mathrm{~cm}^{-}$ ${ }^{3}$, its geometric mean diameter $\mathrm{D}_{\mathrm{g}}=4 \mathrm{~nm}$, and the geometric standard deviation $\sigma_{\mathrm{g}}=1.5$. Assuming that the density of particles is $1.5 \mathrm{~g} \mathrm{~cm}^{-3}$ the mass of that mode is $\sim 1.05 \mathrm{ng} \mathrm{m}^{-3}$. The diffusion losses in the denuder result in a growth of the geometric mean of the size distribution and decrease of mass concentration to $\sim 0.69$ $\mathrm{ng} \mathrm{\textrm {m } ^ { - 3 }}$ which means that $65 \%$ of the mass gets into the SJAC. The fraction of mass penetrating to the SJAC grows with a growing modal diameter so that for a single-mode distribution of $\mathrm{D}_{\mathrm{g}}=10 \mathrm{~nm}$ and $\sigma_{\mathrm{g}}=1.5$ the penetrated mass fraction is $95 \%$.

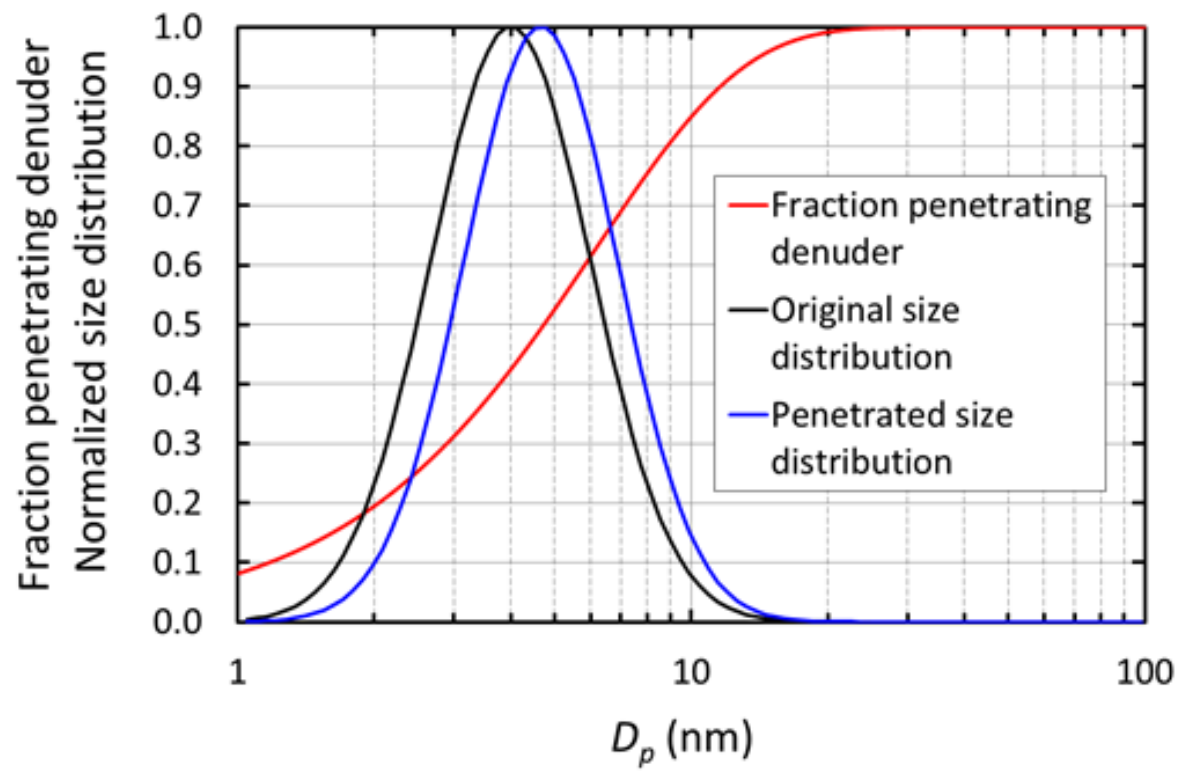

Figure S4. Size-dependent particle penetration probability in the annular denuder of the MARGA and a normalized number size distribution $\left(\mathrm{dN} / \mathrm{d} \log \mathrm{D}_{\mathrm{p}}, \mathrm{D}_{\mathrm{g}}=4 \mathrm{~nm}, \sigma_{\mathrm{g}}=1.5\right)$ of a nucleation mode before and after penetrating the denuder. 


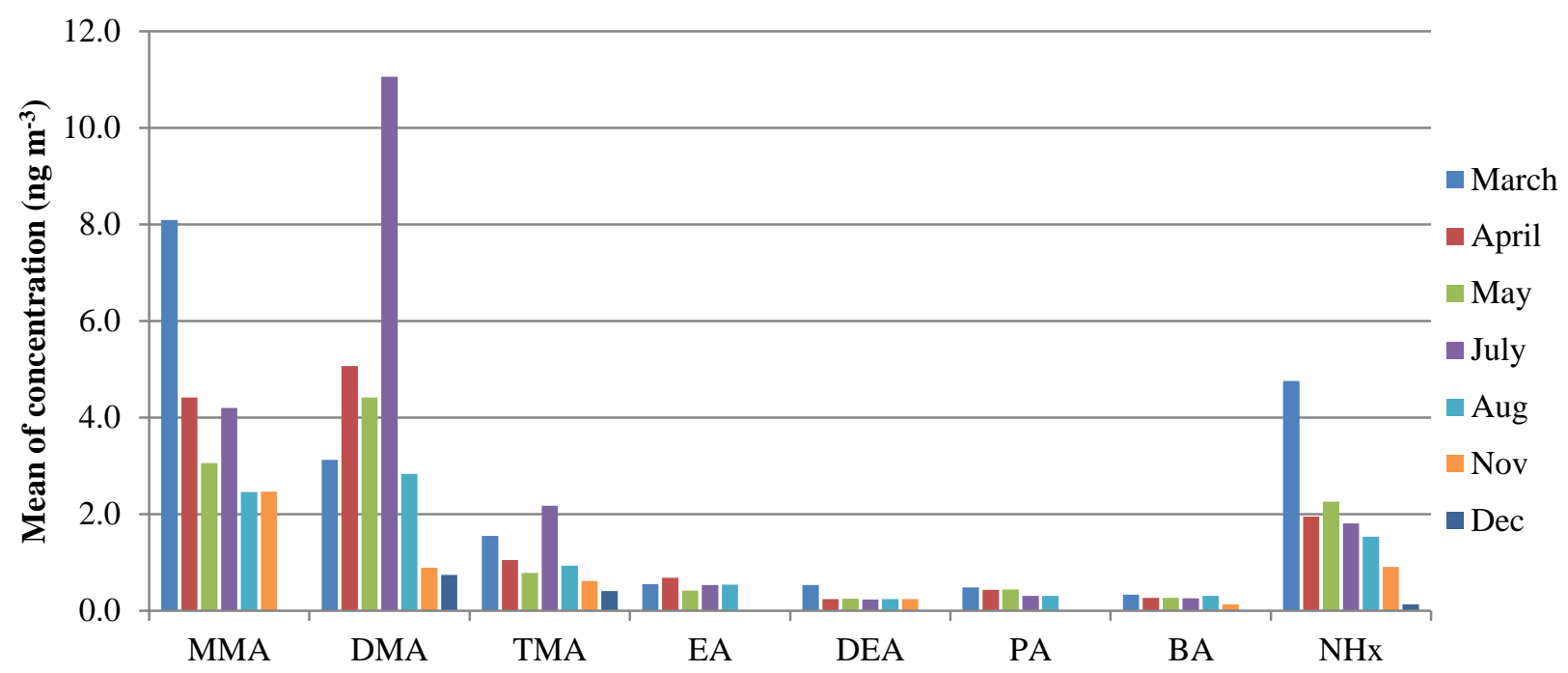

Figure S5. Monthly means of total amine and summed up ammonia and ammonium $\left(\mathrm{NH}_{\mathrm{x}}\right)$ concentrations $\left(\mathrm{ng} / \mathrm{m}^{3}\right) . \mathrm{NH}_{3}+\mathrm{NH}_{4}{ }^{+}$concentrations have been divided by 100 , to fit the scale.

(a)

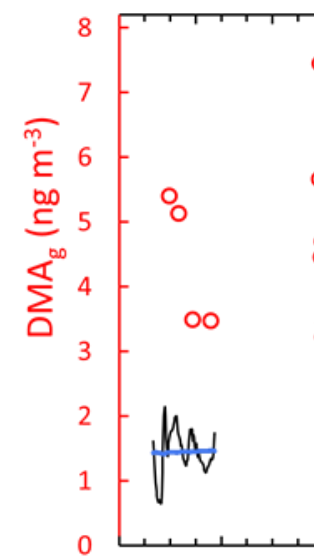

(b)

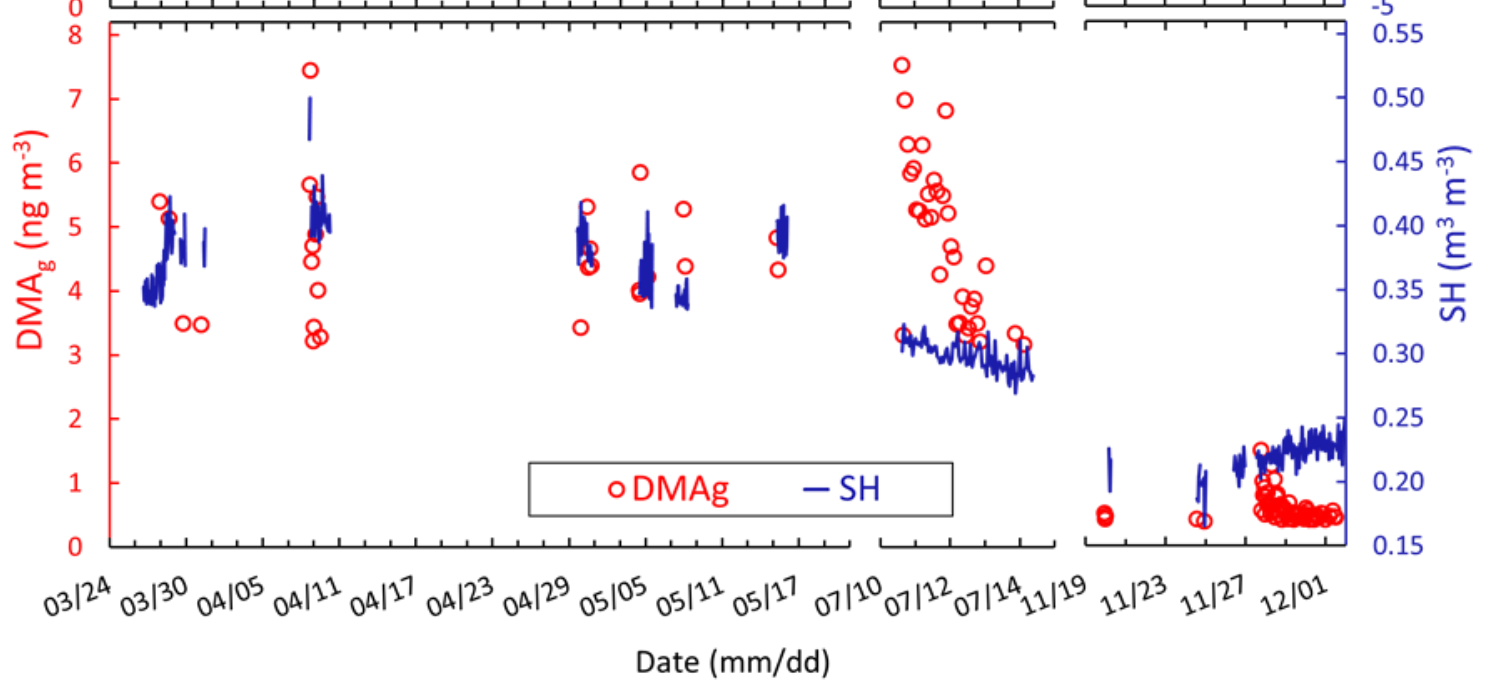

Figure S6. Time series of DMA(g), air temperature (air T), soil temperature (ST) and soil humidity (SH) during the whole measurement period. 

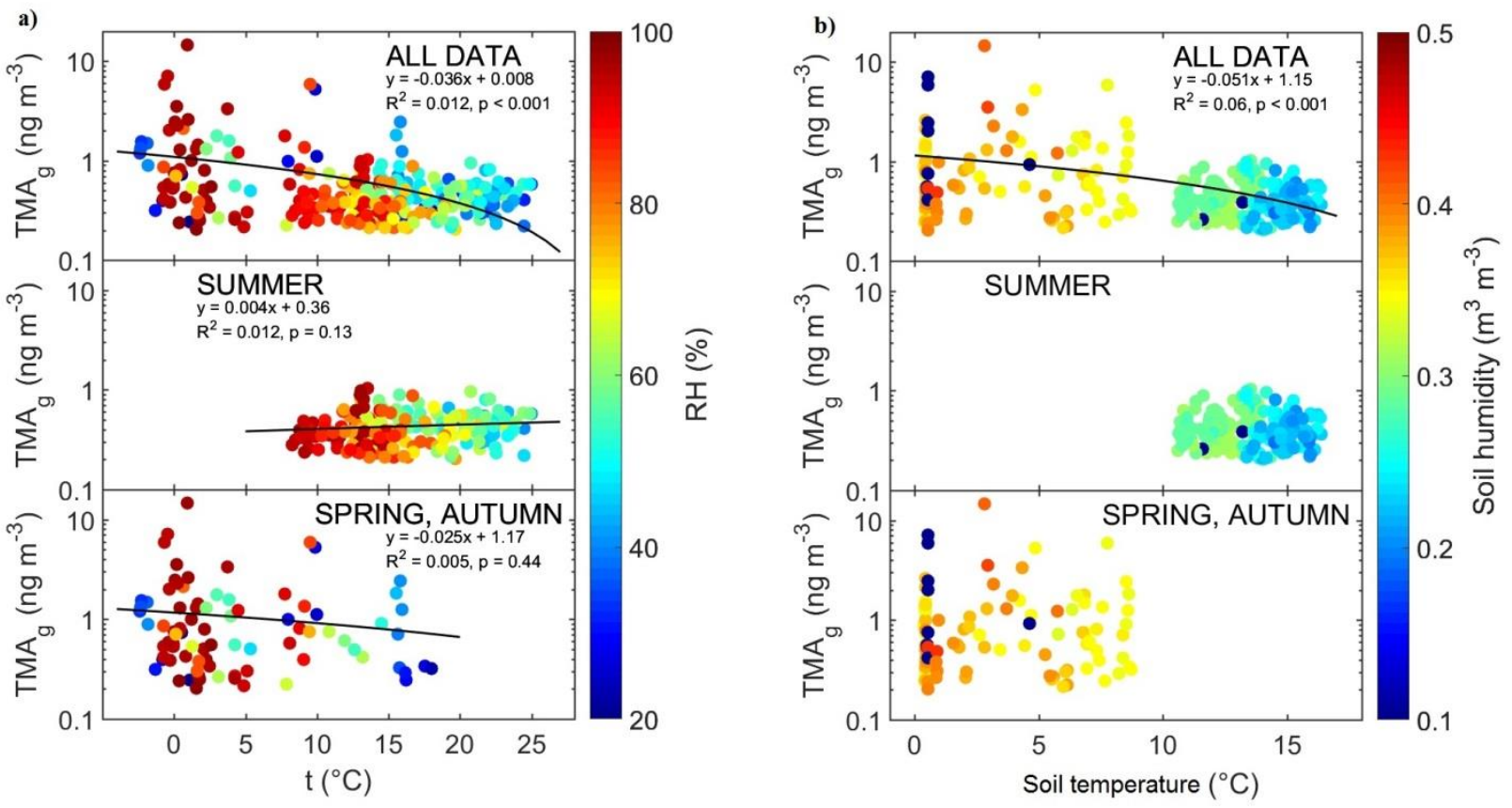

Figure S7. TMA $(\mathrm{g})$ concentration as a function of a) temperature $(\mathrm{RH}=$ relative humidity $)$ and $\mathrm{b})$ Soil temperature.

\section{References}

Baron and Willeke, Aerosol Measurement, 2nd Edition, J Wiley and Sons, 2001.

Fan, B.J., Cheng, Y.S., and Yeh, H.C: Gas Collection Efficiency and Entrance Flow Effect of an Annular Diffusion Denuder, Aerosol Sci. Technol., 25, 113-120, 1996.

Winiwarter, W.: A calculation procedure for the determination of the efficiency in annular denuders. Atmos. Environ. 23, 1997-2002, 1989. 



\title{
Amine and guanidine emissions from a boreal forest floor
}

\author{
Marja Hemmilä ${ }^{1}$, Ulla Makkonen ${ }^{1}$, Aki Virkkula ${ }^{1,2}$, Georgia Panagiotopoulou ${ }^{1}$, Juho Aalto ${ }^{2}$, Markku \\ Kulmala $^{2}$, Tuukka Petäjä ${ }^{2}$, Hannele Hakola ${ }^{1}$, Heidi Hellén ${ }^{1}$ \\ ${ }^{1}$ Finnish Meteorological Institute, P.O. Box 503, 00101 Helsinki, Finland \\ $5 \quad$ Insitute for Atmospheric and Earth System Research / Physics, Faculty of Science, University of Helsinki, Finland
}

Correspondence to: Marja Hemmilä (marja.hemmila@ helsinki.fi)

\begin{abstract}
We measured amine and guanidine emission rates from a boreal forest floor in Finland with 1-h time resolution, using an online ion chromatograph (instrument for Measuring AeRosols and Gases in Ambient air - MARGA) coupled with an electrospray ionization-quadrupole mass spectrometer (MS). MARGA-MS was connected to a closed dynamic flow-

10 through poly(methyl methacrylate) chamber. Chamber recovery for the emission measurements was tested semi-quantitatively for monomethyl-, dimethyl- and trimethylamine (MMA, DMA and TMA), and the results were 19\%, 29\% and 24\%, respectively. MMA, DMA and TMA showed maximum emission rates in July, but the highest emission rates for guanidine were in April, when snow was melting. The MMA, DMA and TMA emission rates also clearly varied diurnally, especially in July with maxima at afternoon. Diethylamine (DEA) also showed higher emission rates, with clear diurnal cycles in July.

15 Other amine emission rates were mostly below the detection limits.

The temperature dependencies of the emissions were studied, and we noted a correlation between the emission rates and chamber temperature $\left(\mathrm{T}_{\text {chamber }}\right)$. Especially in July emission rates of DMA followed $\mathrm{T}_{\text {chamber }}$ measured two hours earlier and guanidine showed a similar pattern. On the other hand, the TMA emission rates correlated with $\mathrm{T}_{\text {chamber }}$ measured at the same time. This could be due to lower vaporizing temperature of TMA. Emission rates of DMA and TMA showed some air temperature $\left(\mathrm{T}_{\text {air }}\right)$ dependency, but for MMA dependency was not as clear.
\end{abstract}

\section{Introduction}

Atmospheric aerosols are important to the climate, because they absorb and scatter solar and thermal radiation, and act as cloud condensation nuclei (IPCC 2013). Amines have been suggested to be key compounds in the secondary aerosol formation by both models (Kurten et al. 2008; Paasonen et al. 2012) and laboratory tests (Angelino et al., 2001; Petäjä et al., 2011; Yu et al., 2012; Almeida et al., 2013; Glasoe et al., 2015). Amines are gaseous bases, whose general formula is $N R_{3}$, where $R$ denotes hydrogen or alkyl or aryl group. Since gas-phase amines cluster efficiently with atmospheric acid clusters (such as sulphuric acid, Kurtén et al. 2011) and therefore participate in neutralization in the atmosphere, it is difficult to detect their true atmospheric concentrations. Gas-phase amine concentrations from boreal forest air have been measured in a few studies (Sellegri et al., 2005; Kieloaho et al., 2013; Kulmala et al., 2013, Sipilä et al., 2015; Hemmilä et al., 2018). In these stu dies, 
and the analysis method used. The main known anthropogenic sources of amines globally are animal husbandry, industry and composting processes, while natural sources are assumed to be oceans, biomass burning, vegetation and soil (Ge et al., 2011; Sintermann et al. 2014). Degradation of organic nitrogen compounds, especially carboxylation of amino acids, may be a source of low-weight alkylamines in soils (Yan et al., 1996). Under aerobic conditions, e.g. proteins, carnitine and choline in soil, could be degraded to trimethylamine (TMA) and further dimethyl- (DMA) and methylamines (MMA) (Rappert and Müller 2005). Amines from soil can probably enter the atmosphere via volatilization (Ge et al., 2011).

However, direct flux measurements of alkylamines are difficult to perform and are very rarely done (Sintermann and Neftel, 2015), due to the high reactivity of amines and the lack of suitable measurement techniques. Amines also are 'sticky', so they are easily lost in the inlets of instruments. In our previous study (Hemmilä et al., 2018) we developed a method for measuring atmospheric amines, using an in situ ion chromatograph (IC) connected to a mass spectrometer (MS), and we measured the ambient concentrations of different amines at the boreal forest site. We found that melting snow and soil may be potential sources of amines, especially MMA and TMA. Kieloaho et al. (2017) estimated the magnitudes of soil-atmosphere fluxes of DMA and diethylamine (DEA), using a gradient-diffusion approximation based on measured concentrations in soil solution and in the canopy air space. They found that boreal forest soil is a possible source of DMA and a sink for DEA. The idea of melting snow and soil as amine sources and also the study by Kieloaho et al. (2017) inspired us to measure boreal forest floor emissions.

Other strong bases can also be relevant to aerosol formation. For example, in a recent model study, the role of a strong organobase, guanidine, was examined in a sulphuric acid-driven new-particle formation (Myllys et al., 2018). The authors concluded that much less guanidine is needed for efficient particle formation than for DMA, which explains why we included

50 guanidine in the study. Guanidine is a catabolite of arginine and has been found in urine (Marescau et al. 1992, Van Pilsum et al., 1956). Arginine concentrations have been detected in a boreal forest in Alaska, USA (Werdin-Pfisterer et al., 2009).

The aim here was to examine amine and guanidine emissions from melting snow and from the boreal forest floor, using a closed dynamic flow-through chamber during different seasons. This method has been commonly used for studying biogenic volatile organic compounds (BVOCs), especially mono- and sesquiterpene and isoprene emissions from boreal forest soil (Hellén et al., 2006; Aaltonen et al., 2011; Mäki et al., 2017).

\section{Experimental}

\subsection{Measurement site}

Forest floor emission measurements were performed at SMEAR II (Station for Measuring Forest Ecosystem-Atmosphere Relations II) station in Hyytiälä, southern Finland (610510`N, 24o170E, 180 m a.s.l., Hari and Kulmala, 2005) from March

60 to September 2018 about 1 week per month. The forest stand at the SMEAR II station is $\sim 60$ years old, $\sim 19 \mathrm{~m}$ height and dominated by Scots pine (Pinus sylvestris L.) (75\% of stand basal area). Also, some Norway spruce (Picea abies (L) H. Karst), aspen (Populus tremula L.) and birch (Betula L.) also grow in the forest. The most common vascular plant species at ground 
level are lingonberry (Vaccinium vitis-idaea L.), bilberry (Vaccintum myrtillus L.), wavy hair-grass (Deschampsia flexuosa (L.) Trin.) and heather (Calluna vulgaris (L.) Hull.), and the most common mosses are Schreber's big red stem moss 65 (Pleurozium schreberi (Brid.) Mitt.) and dicranum moss (Dicranum Hedw.) (Ilvesniemi et al, 2009). The soil above the homogenous bedrock is Haplic podzol on glacial till.

\subsection{Measurement method}

The emissions were measured, using a flow-through technique with a stainless-steel collar, a poly(methyl methacrylate) (PMMA) chamber $(60 \mathrm{~cm} * 60 \mathrm{~cm} * 80 \mathrm{~cm})$ and 12-m-long heated fluorinated ethylene propylene (FEP) tubing.

70 Polytetrafluoroethene and stainless steel were also tested as chamber materials, but PMMA was the most useful. The collar was installed in autumn 2011 close to our container, where the analytical instrumentation was located. Soil surface coverage of the chamber area was determined by visual inspection and photographs (see Fig. S1). Based on this analysis the chamber area included litter, lingonberries, bilberries and a few chickweed-wintergreens (Trientalis europaea L.). Samples from the chamber air were directed to MARGA (Monitor for AeRosols and Gases in Ambient air (Metrohm-Applikon, Schiedam, The

75 Netherlands) (ten Brink et al., 2007), which is an online-IC. Makkonen et al. measured inorganic gases and aerosols with the MARGA instrument, both in urban (2012) and rural (2014) environments. In addition, the MARGA system was connected to an electrospray ionization-quadrupole MS (Shimadzu LCMS-2020, Shimadzu Corporation, Kyoto, Japan) to improve the sensitivity of the amine measurements (Hemmilä et al., 2018). Since July, we also used PM10-cyclone (URG 1032, Tefloncoated) with the inlet tubing.

We measured six different amines and guanidine; the amines included MMA, DMA, TMA, ethylamine (EA), DEA and propylamine (PA), and the detection limits for the analysis system of MARGA-MS were 1.0, 13.4, 14.2, 1.8, 1.2 and 1.6 $\mathrm{ng} \mathrm{m} \mathrm{m}^{-2} \mathrm{~h}^{-1}$, respectively for the amines, and $3.4 \mathrm{ng} \mathrm{m}^{-2} \mathrm{~h}^{-1}$ for guanidine. Calibration for the system was done one to two times per month; see details from Hemmilä et al. (2018). The emission rate (E) was calculated from the MARGA-MS results with equation 1 as follows:

85

$E=\frac{C * F_{\text {in }}}{A}$

where $\mathrm{c}$ is the measured concentration $\left(\mathrm{ng} \mathrm{m}^{-3}\right)$, Fin is the flow to the chamber $\left(\mathrm{m}^{3} \mathrm{~h}^{-1}\right)$ and $\mathrm{A}$ is the enclosed forest floor area $\left(\mathrm{m}^{2}\right)$.

For more detailed description of the amine analysis method, see Hemmilä et al. (2018). Guanidine was included in the previous method, since it is an efficient compound for new particle formation (Myllys et al., 2018). The sampling time was $1 \mathrm{~h}$, sample flow rate was $16.71 \mathrm{~min}^{-1}$ and the sampled air was replaced with amine-free air (flow rate $251 \mathrm{~min}^{-1}$ ). We used an oxalic acid filter to remove bases from the air that went into the chamber. 
The functionality of the chamber was tested with a permeation oven. In this process, air containing 501,630 and 3005 ng $\mathrm{m}^{-3}$ of MMA, DMA and TMA, respectively, was flushed into the chamber at a flow rate of $251 \mathrm{~min}^{-1}$. The concentrations inside the chamber were measured with MARGA-MS and the 12-m long heated FEP inlet tubing. We found that the recoveries of the MMA, DMA and TMA were only 19\%, 29\% and 24\%, respectively, so wall losses were significant in the chamber. The FEP and stainless-steel chambers were also tested, but with the FEP-chamber recovery was poorer and the stainless-steel chamber had a too high background level. Since the recovery test results were only semi-quantitative and made only for MMA, DMA and TMA, we did to not take them into account when showing the emission measurement results. Therefore, the true emissions were expected to be higher than as found in this study.

\subsection{Meteorological conditions}

The meteorological quantities for the chamber system included measurement of relative humidity (RH) sensors (Honeywell HIH-400; Honeywell International Inc., Charlotte, NC, USA and Rotronic Hygroclip XD; Rotronic AG, Bassersdorf, Switzerland), temperature (T) sensors (TI LM35; Texas Instruments, Dallas, TX, USA and Rotronic Hygroclip XD; Rotronic AG ), photosynthetically active radiation (PAR) sensors (Apogee SQ-520; Apogee Instruments Inc., Logan, UT, USA and a Li-cor LI-190R quantum sensor; LI-COR Biosciences Inc., Lincoln, NE, USA). The ambient meteorological quantities for the site were obtained from the SmartSmear AVAA portal (Junninen et al., 2009). SmartSmear is the data portal used for visualization and downloading of continuous atmospheric, flux, soil, tree, physiological and water quality measurements at the SMEAR research stations of the University of Helsinki.

\section{Results and discussion}

\subsection{Emissions of different amines and guanidine}

We measured the amine and guanidine emissions from the boreal forest floor in April, May, July and September in 2018. In Fig. 1 the average emissions in every month are shown. MMA, DMA, TMA, and DEA showed maximum emissions in July,

115 but guanidine already showed the highest emissions in spring. In our previous ambient air study (Hemmilä et al., 2018) we observed that DMA and TMA also showed their maximum ambient air concentrations in July. In that study, MMA showed maximum ambient air concentrations in spring, but here the highest emission rates from the forest floor were measured in summer. The MMA still showed higher emission rates in April than did DMA or TMA, which could be explained by its lower boiling point, so it vaporizes more readily. Sarwar et al. (2005) measured ammonia emissions in a pine forest in Texas and obtained an average result in the summer months of $0.09 \mathrm{~kg} \mathrm{~km}^{-2}$ per month or approximately $12500 \mathrm{ng} \mathrm{m}^{-2} \mathrm{~h}^{-1}$, which is about 35 times higher than our maximum average DMA emissions (320 ng m $\left.\mathrm{m}^{-2} \mathrm{~h}^{-1}\right)$. In taking into account our measurements, $29 \%$ recovery for DMA, the emission rates measured by Sawar et al. were about 10 times higher than ours. Figures 2 and 3 show the diurnal variations in photosyntetically active radiation (PAR), chamber temperature ( $\mathrm{T}_{\text {chamber }}$ ), soil surface temperature $\left(\mathrm{T}_{\text {soil }}\right)$ and soil surface humidity $(\mathrm{SH})$ during measurement periods in April, May, July and September. The diurnal cycles for 
https://doi.org/10.5194/acp-2019-1157

Preprint. Discussion started: 14 January 2020

(c) Author(s) 2020. CC BY 4.0 License.

(c) (i)

125 the environmental conditions and amine and guanidine fluxes were expressed as hourly means on a monthly basis. Due to the MARGA-MS instrument features, some data were shown in zigzag patterns; for more information, see Hemmilä et al. (2018).

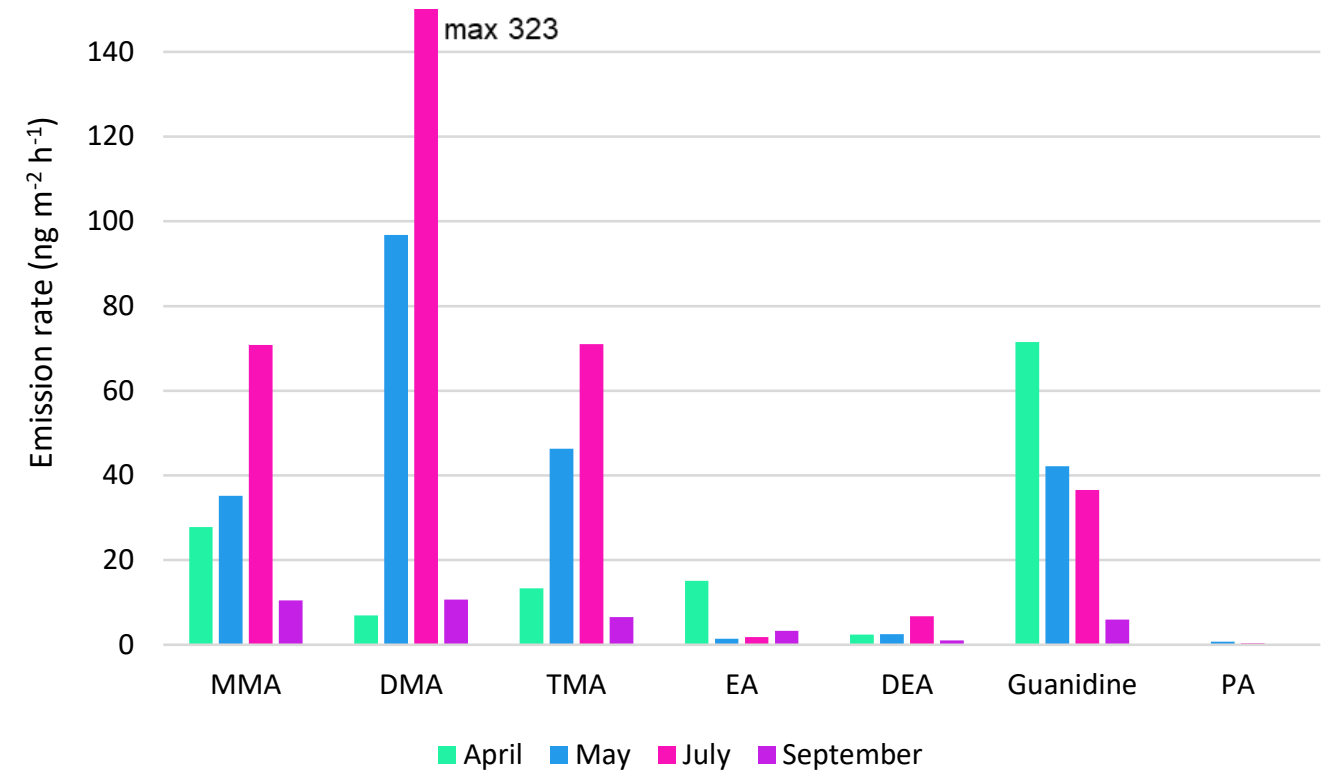

Figure 1: Average monomethyl- (MMA), dimethyl- (DMA), trimethyl- (TMA), ethyl- (EA), diethyl- (DEA) and propylamine (PA) and guanidine emission rates $\left(\mathrm{ng} \mathrm{m}^{-2} \mathrm{~h}^{-1}\right)$ in different months.

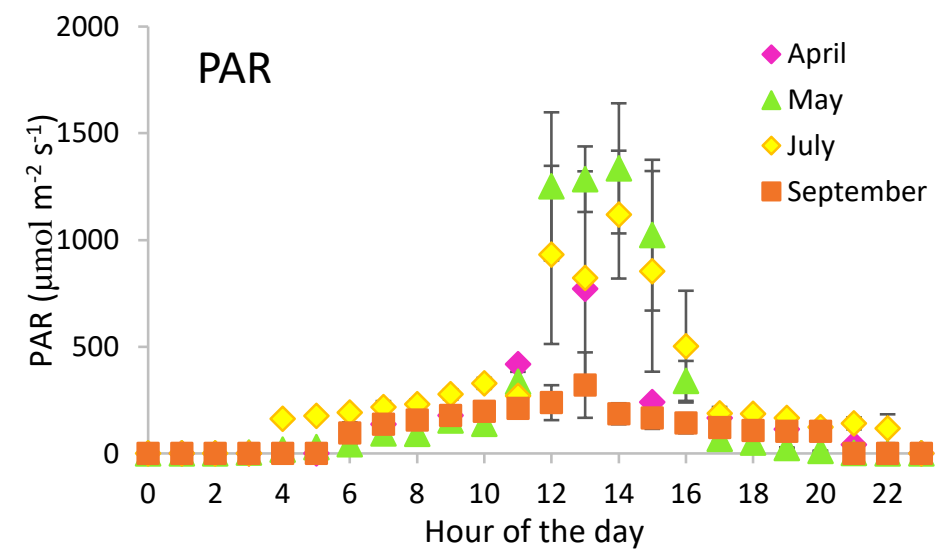

135 Figure 2: Diurnal variation in photosynthetically active radiation (PAR) during measurement periods in April, May, July and September. The error bars show the standard deviation between the measured values. 

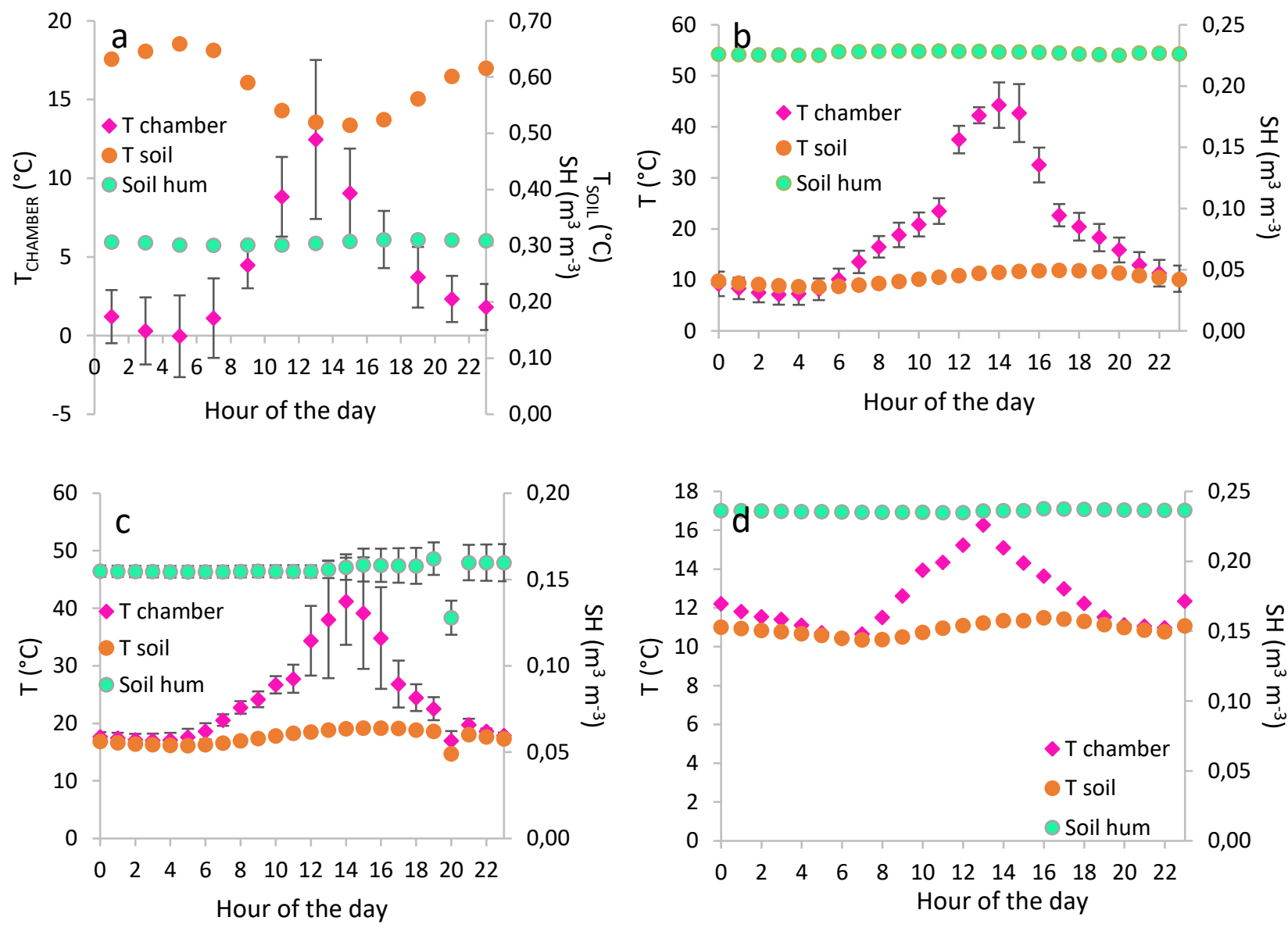

140 Figure 3: Diurnal variations in chamber $\left(\mathbf{T}_{\text {chamber }}\right)$ and soil surface temperature $\left(\mathbf{T}_{\text {soil }}\right)\left({ }^{\circ} \mathbf{C}\right)$ and soil surface humidity $\left(\right.$ soil hum) $\left(\mathbf{m}^{3}\right.$ $\mathbf{m}^{-3}$ ) during measurement periods in April (a), May (b), July (c) and September (d). The error bars show the standard deviation between the measured values. In September, adding the error bar changed the scale so that the variations in diurnal cycle were blurred. Note the difference in emission rate axis length between the figures.

145 Figure 4 shows the mean diurnal variation in emission rates of MMA in April, May, July and September 2018. The emission rates of MMA in April were quite low $\left(\sim 30 \mathrm{ng} \mathrm{m}^{-2} \mathrm{~h}^{-1}\right)$ with no clear diurnal variation, but in May and even more so in July, they increased and showed clear diurnal variation with maxima in the late afternoon and minima in the early morning. In September, the emission rates of MMA were mostly under the detection limits, but again the highest emission rates were in the late afternoon. 

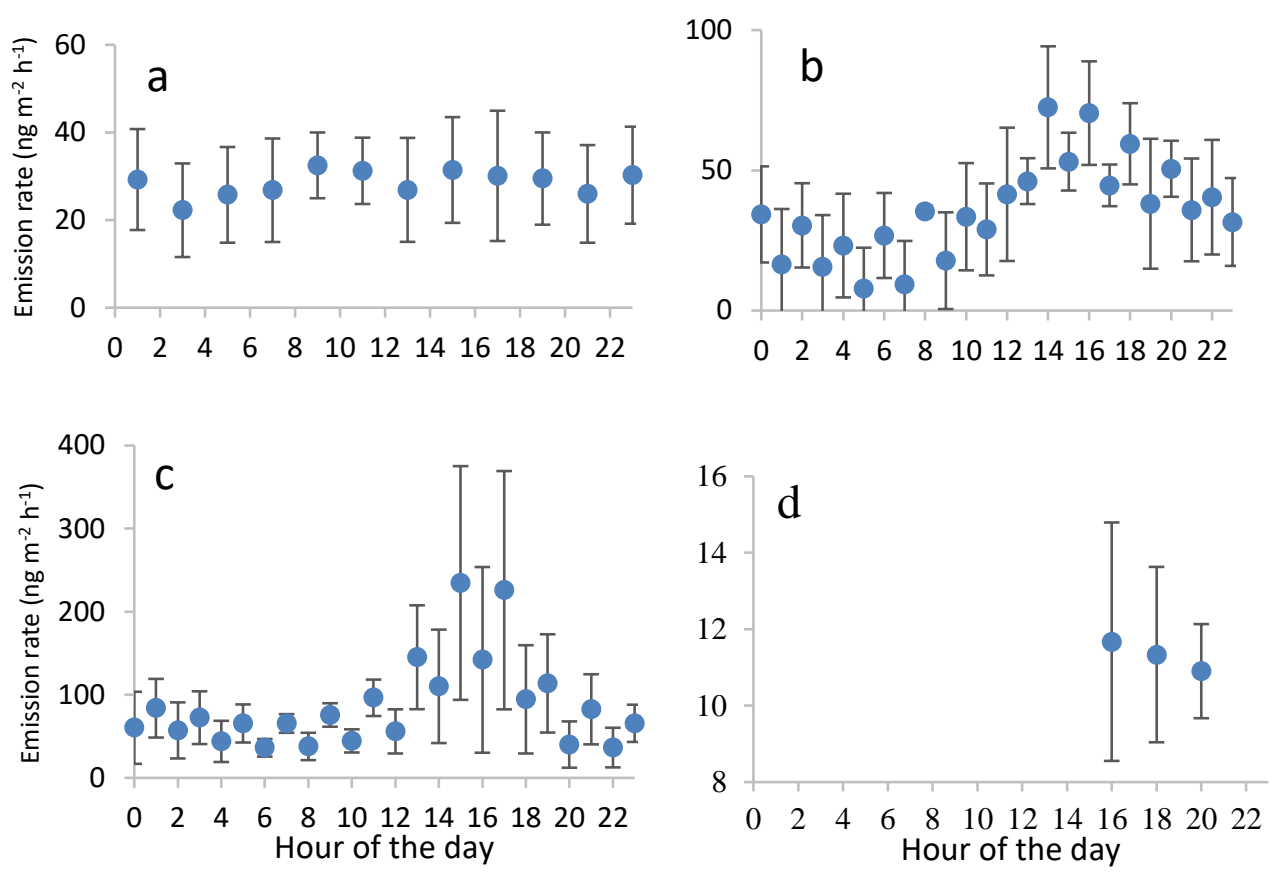

Figure 4: Diurnal variations in monomethylamine emission rates in April (a), May (b), July (c) and September (d). The error bars show the standard deviation between the measured values. Note the difference in emission rate axis length between the figures.

The DMA showed clear diurnal cycles (Fig. 5) in every measurement period, with maxima in the afternoon. In spring, the emission rates were quite modest, but became more intense as summer proceeded. The highest emissions for DMA were in July, when the average afternoon maximum was over $1000 \mathrm{ng} \mathrm{h}^{-1} \mathrm{~m}^{-2}$. In September, the emission rates decreased to even lower values than in April, but they still showed maxima in the afternoon. Kieloaho et al. (2013) also measured at the same site high DMA+EA concentrations in the ambient air during July, but even higher ambient concentrations were measured in autumn. Even though both measurements were conducted at the same site, there were more possible sources, meteorological conditions and removal mechanisms contributing to ambient air concentrations and this may explain the difference in behaviour. Based on the 2013 data and a model, Kieloaho et al. (2017) concluded that boreal forest soil is a source of DMA, and our measurements confirmed this.

The DEA emission rates were generally quite low and diurnal variability was only detected in July with maxima ( $30 \mathrm{ng} \mathrm{h}^{-1} \mathrm{~m}^{-2}$ ) in the afternoon (Fig. 6). Our measurements agree with those of Kieloaho et al. (2013), who also detected the highest DEA concentrations in the ambient air in summer. However, Kieloaho et al. (2017) focused on DEA soil flux dependence on different physical and chemical state variables and noted, that the flux estimates were especially sensitive to soil $\mathrm{pH}$ changes. The typical $\mathrm{pH}$ of boreal forest soil was 5.3, and the compensation point of DEA was 5.7. Based on this,

170 Kieloaho et al. concluded that boreal forest soil could be a possible sink for DEA, whereas our afternoon maxima suggested soil emissions. The soil $\mathrm{pH}$ was not measured, so we do not know if this could have caused the discrepancy. 

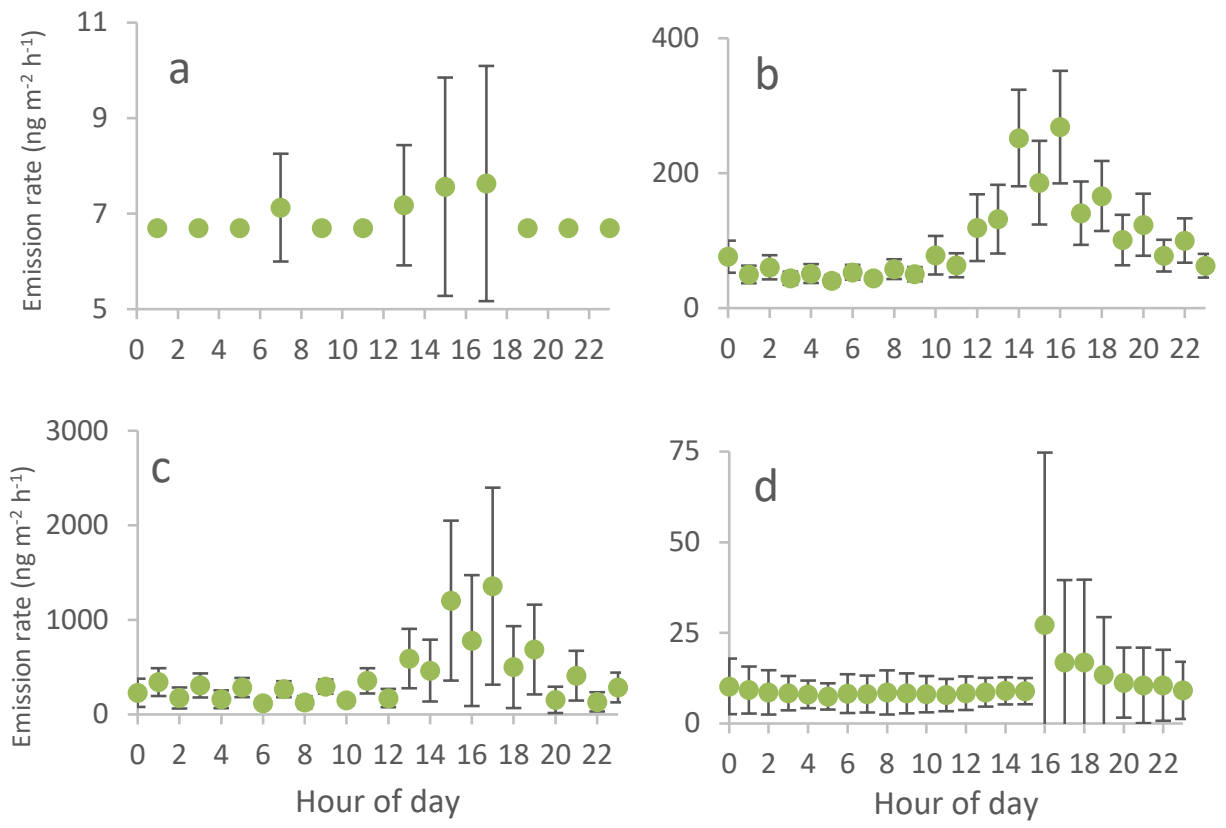

175 Figure 5: Diurnal variations in DMA emission rates in April (a), May (b), July (c) and September (d). The error bars show the standard deviation between the measured values. Note the difference in emission rate axis length between the figures.

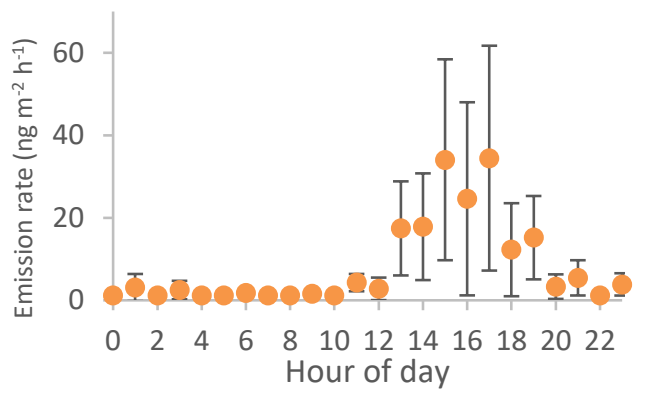

Figure 6: Diurnal variations in diethylamine emission rates in July. The error bars show the standard deviation between the measured values.

The TMA, similar to DMA, showed clear diurnal cycles in every measurement period (Fig. 7). The emission rates were similar to those of DMA in April and September, but in May (maximum $\sim 80 \mathrm{ng} \mathrm{h}^{-1} \mathrm{~m}^{-2}$ ) and July (maximum $\sim 300 \mathrm{ng} \mathrm{h}^{-1} \mathrm{~m}^{-2}$ ) they were significantly lower than the DMA emission rates. However, the emissions of TMA were higher than the MMA emissions in July. The TMA and MMA seemingly showed maxima earlier in the afternoon than DMA, which could be explained by their more ready vaporization. 
https://doi.org/10.5194/acp-2019-1157

Preprint. Discussion started: 14 January 2020

(c) Author(s) 2020. CC BY 4.0 License.

(c) (i)
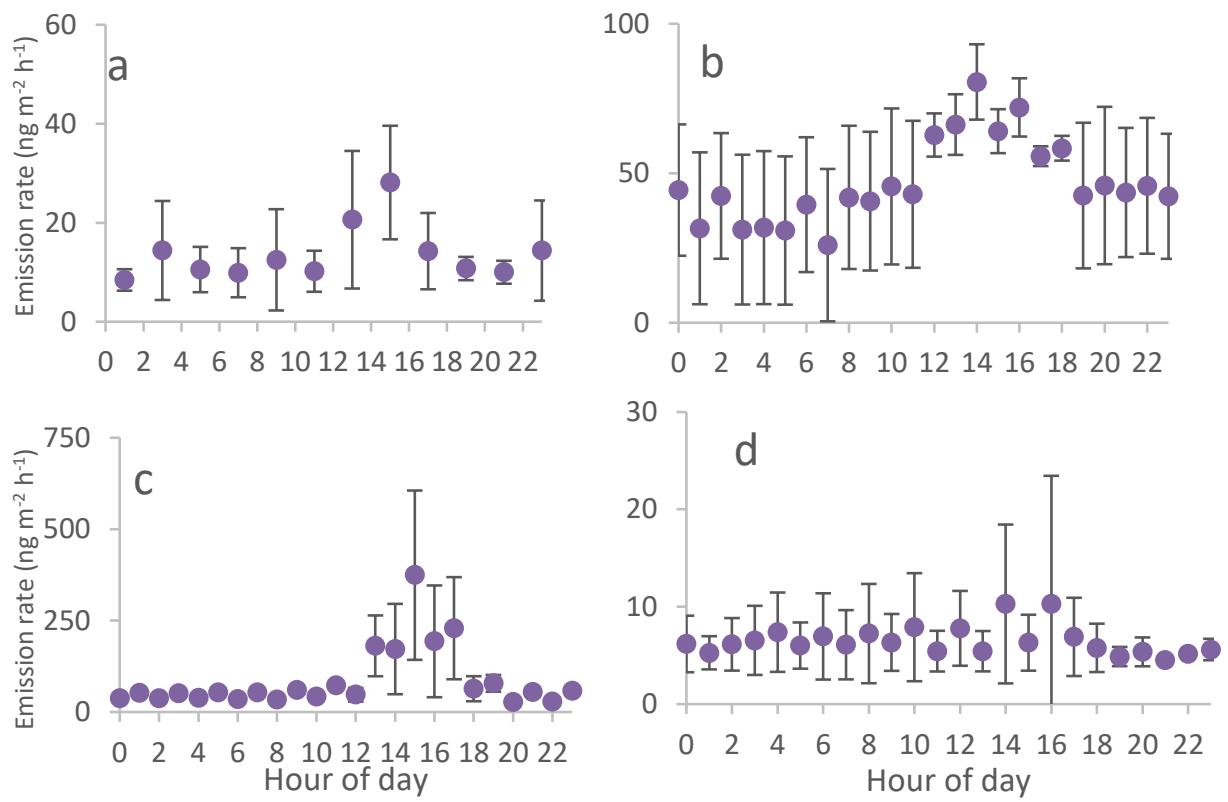

Figure 7: Diurnal variations in trimethylamine emission rates in April (a), May (b), July (c) and September (d). The rror bars show the standard deviation between the measured values. Note the difference in emission rate axis length between the figures.

Guanidine did not show as clear a diurnal variation as did MMA, DMA or TMA (Fig. 8). Unlike the other compounds, guanidine showed the highest emission rates in April, which could indicate it was trapped in snow. 

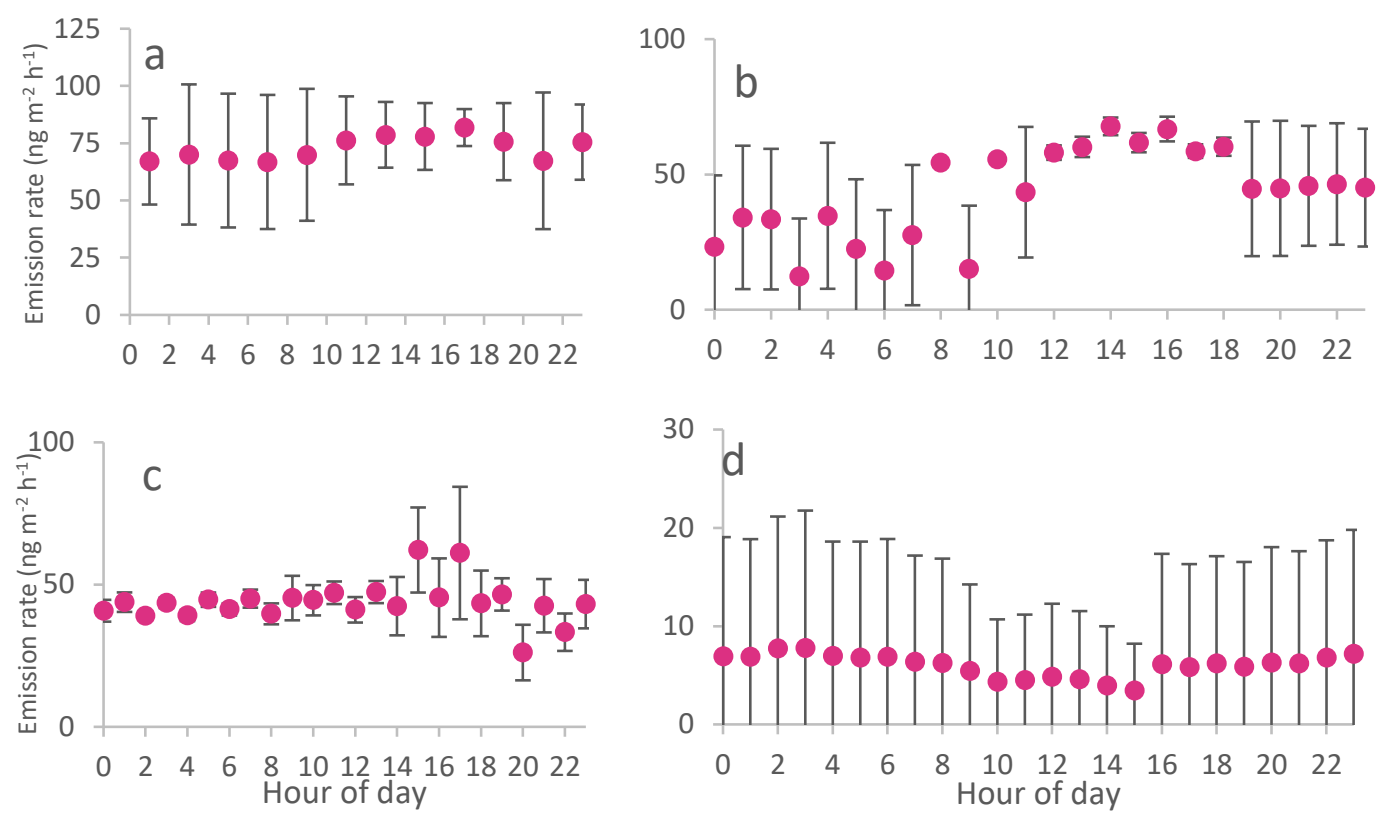

Figure 8: Diurnal variations and error bars of guanidine emission rates in April (a), May (b), July (c) and September (d). The error bars show the standard deviation between the measured values. Note the difference in emission rate axis length between the figures.

\subsection{Temperature dependency of emissions}

In May and July, the diurnal variation in amine emission rates, especially for DMA, followed chamber temperature (Fig. 9a and $b$ ). The $T_{\text {chamber }}$ dependence was best shown when the DMA and guanidine emissions were plotted against $\mathrm{T}_{\text {chamber }}$ measured two hours earlier (Fig. 10, Table 1). Due to the large size of the chamber compared with that of the flow going in, it requires time before the concentration stabilizes to the new level of the emissions. However, for TMA we did not detect as clear a difference, possibly because TMA evaporates more readily than DMA. It may also require possible some time for the DMA emissions to react to the temperature changes of the chamber air. The large size of the chamber could have resulted an hour's delay in the emission rates. For example, the temperature of soil surface layer, which could be a source of these compounds, is expected to follow ambient air temperature changes slowly behind. This also indicates that soil could be the main source of DMA and guanidine, but for TMA the source could be surface vegetation, which respond more readily to the changes in the air temperature.

For DMA $\mathrm{T}_{\text {chamber }}$ dependency was better illustrated with an exponential curve and for TMA and guanidine with a linear curve. Table 1 shows that the daily emission potentials at $30^{\circ} \mathrm{C}$ for DMA were clearly higher in July than in May, whereas the emission potentials of TMA and guanidine remained similar in both months. The $\mathrm{T}_{\text {chamber }}$ and the PAR were well correlated in May and July. Unfortunately, the RH data of the chamber were not collected during July. We believe, that the 
215 higher DMA emission potential in July could have been due to higher activity in the soil processes. The mean monoterpene emission potential (at $30^{\circ} \mathrm{C}$ ) in July of the forest floor at the same site was $6.44 \pm 7.54 \mu \mathrm{g} \mathrm{m}^{2} \mathrm{~h}^{-1}$ and sesquiterpene $0.15 \pm 0.29$ $\mu \mathrm{g} \mathrm{m}^{2} \mathrm{~h}^{-1}$ during the growing season in 2015 (Wang et al., 2018). These emission potentials for monoterpenes were 10-230 times higher and for sesquiterpenes $0.2-5$ times higher than our calculated emission potentials of amines during May and July 2018. The measured recovery from our chamber was $\sim 25 \%$ for amines; therefore, the true emission was expected to be four times higher, but still clearly lower than the monoterpene emissions. In comparison to the emission rates sesquiterpene, the fixed amine emission rates were probably similar.

Even though the diurnal variation in DMA followed the $\mathrm{T}_{\text {chamber }}$ quite well, there were wide variations in the emission rates of different days. For example, in July the emission rates suddenly dropped in the $20^{\text {th }}$ and more dramatically in the $21^{\text {st }}$. Clearly, other important factors affected the emissions. We compared our emission rate data with additional data and noted, that the PAR values were also lower on the $20^{\text {th }}$ and $21^{\text {st }}$ and it was slightly rainy in the evening of $20^{\text {th }}$ and in the early afternoon of $21^{\text {st }}$. The soil surface water content also began increase in the evening of $20^{\text {th }}$. Amines are water-soluble and can therefore be flushed away during the rain or remain on the wet surfaces.
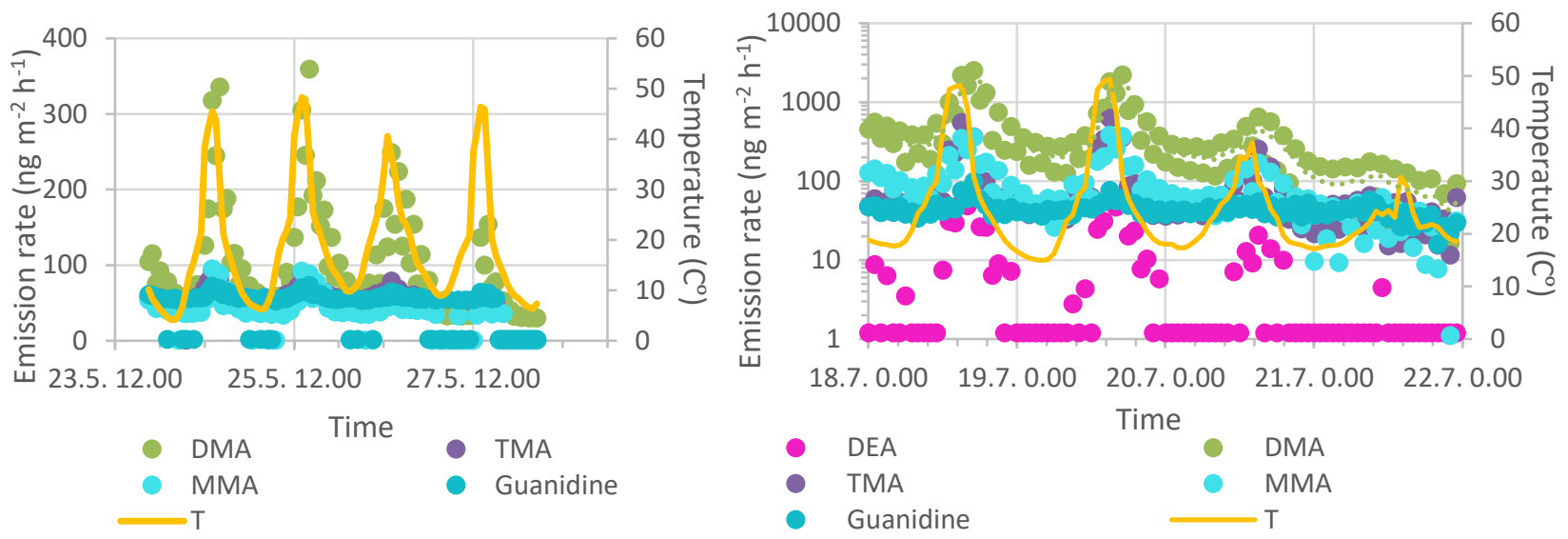

Figure 9: Time series of amine and guanidine emission rates $\left(\mathrm{ng} \mathrm{m}^{-2} \mathbf{h}^{-1}\right)$ and temperature of the chamber $\left({ }^{\circ} \mathrm{C}\right)$ in $\mathrm{May}$ and $\mathrm{July}$ 2018. 


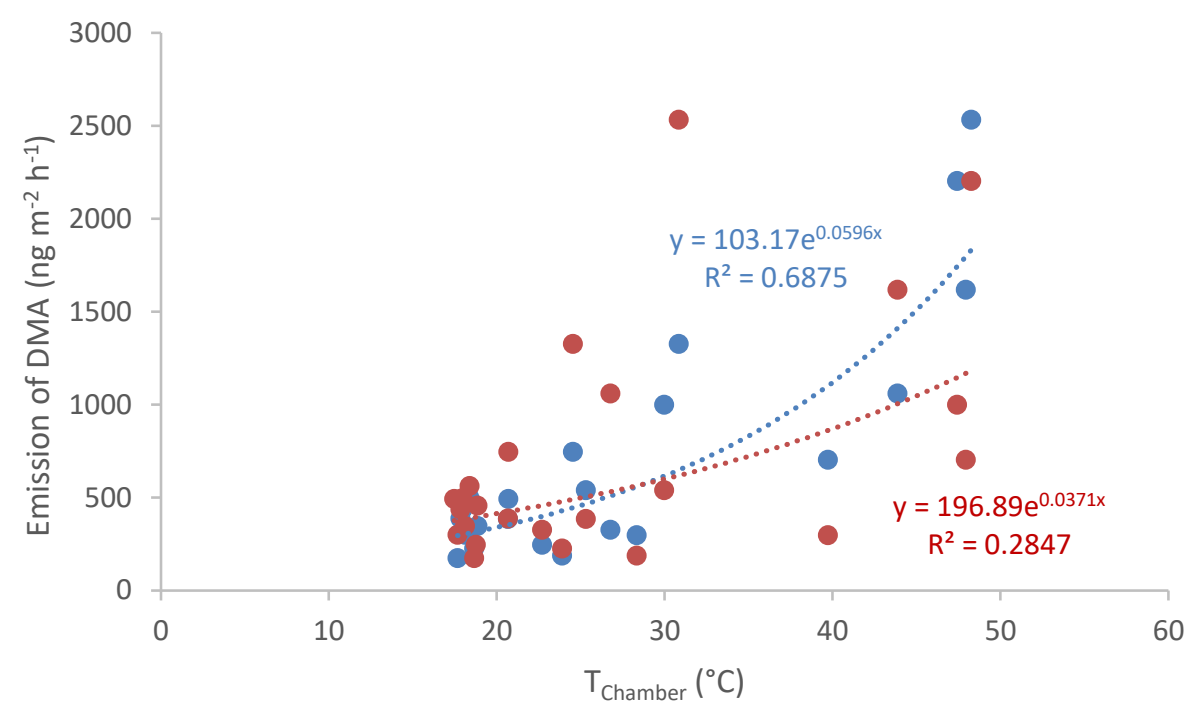

Figure 10: Emissions of DMA 18.7.2018 compared with chamber temperature at the same time (red) and chamber temperature two hours earlier (blue).

Table 1: Calculated emission potentials of DMA (exponential function), TMA and guanidine (linear function) at temperature of 30 ${ }^{\circ} \mathrm{C}$ on different dates. The red values mark that the coefficient of determination $\left(R^{2}\right)$-value was low. Other curve parameters are in Supplement Table ST1.

\begin{tabular}{cccc|cc|ccc}
\hline & \multicolumn{3}{c|}{ DMA } & \multicolumn{2}{c|}{ TMA } & \multicolumn{3}{c}{ Guanidine } \\
\hline Date & $\begin{array}{c}\text { Emission } \\
\text { potential } \\
\left(\mathrm{ng} \mathrm{m}^{-2} \mathrm{~h}^{-1}\right)\end{array}$ & $\mathrm{R}^{2}$ & $\begin{array}{c}\mathrm{R}^{2} \text { without } \\
\text { temperature } \\
\text { move }\end{array}$ & $\begin{array}{c}\text { Emission } \\
\text { potential } \\
\left(\mathrm{ng} \mathrm{m}^{-2} \mathrm{~h}^{-1}\right)\end{array}$ & $\mathrm{R}^{2}$ & $\begin{array}{c}\text { Emission } \\
\text { potential } \\
\left(\mathrm{ng} \mathrm{m}^{-2} \mathrm{~h}^{-1}\right)\end{array}$ & $\mathrm{R}^{2}$ & $\begin{array}{c}\mathrm{R}^{2} \text { without } \\
\text { temperature } \\
\text { move }\end{array}$ \\
\hline 24.5. & 161 & 0.86 & 0.64 & 68 & 0.48 & 61 & 0.28 & 0.18 \\
25.5. & 152 & 0.86 & 0.64 & 65 & 0.72 & 59 & 0.35 & 0.35 \\
26.5. & 149 & 0.70 & 0.50 & 63 & 0.58 & 59 & 0.19 & 0.11 \\
27.5. & 69 & 0.73 & 0.38 & 36 & 0.47 & 42 & 0.37 & 0.41 \\
18.7. & 617 & 0.69 & 0.28 & 147 & 0.58 & 51 & 0.61 & 0.15 \\
19.7. & 506 & 0.78 & 0.41 & 168 & 0.66 & 49 & 0.68 & 0.56 \\
20.7. & 277 & 0.16 & 0.15 & 102 & 0.31 & 45 & 0.057 & 0.097 \\
21.7. & 43 & 0.05 & 0.0055 & 33 & 0.0047 & 28 & 0.17 & 0.0068 \\
\hline
\end{tabular}

The emission rates of amines were also compared with $\mathrm{T}_{\text {chamber }}$ and chamber relative humidity $\mathrm{RH}_{\text {chamber }}$ (Fig. 11a) measured at the same time. With higher $\mathrm{RH}_{\text {chamber }}$ and lower $\mathrm{T}_{\text {chamber, }}$, the emissions of MMA and DMA were lower, while the TMA emissions did not express the same pattern. In Fig. 11a, the highest measured emissions are missing 
because our $\mathrm{RH}_{\text {chamber }}$ sensor was unfortunately out of order in July. In Fig. 11b, the emission rates of MMA, DMA

and TMA were compared with $\mathrm{T}_{\text {air }}$ and air relative humidity $\left(\mathrm{RH}_{\text {air }}\right)$ measured at the same time. For DMA and TMA, the emission rates showed some $T_{\text {air }}$ dependency, but for MMA the dependency was not as clear $\left(\mathrm{R}^{2}=0\right.$. $46, \mathrm{R}^{2}=0.47$ and $\mathrm{R}^{2}=0.26$ for DMA, TMA and MMA, respectively). From the exponential function $\mathrm{y}=\mathrm{E}_{0} \exp (\mathrm{kt})$, it can be seen that $\mathrm{k}_{\mathrm{DMA}}$ is about two times that of $\mathrm{k}_{\mathrm{TMA}}$ and about 15 times that of $\mathrm{k}_{\mathrm{MMA}}$, suggesting that the DMA emissions are two times more sensitive to $\mathrm{T}_{\text {air }}$ changes than the TMA emissions and about 15 times more sensitive than the MMA emissions. The emission rates did not seemingly show any dependency of $\mathrm{RH}_{\text {air. }}$ In our previous study (Hemmilä et al., 2018) we noted that gas-phase DMA concentrations showed $\mathrm{T}_{\text {air }}$ dependency $\left(\mathrm{R}^{2}=0.55\right)$, confirming these results.
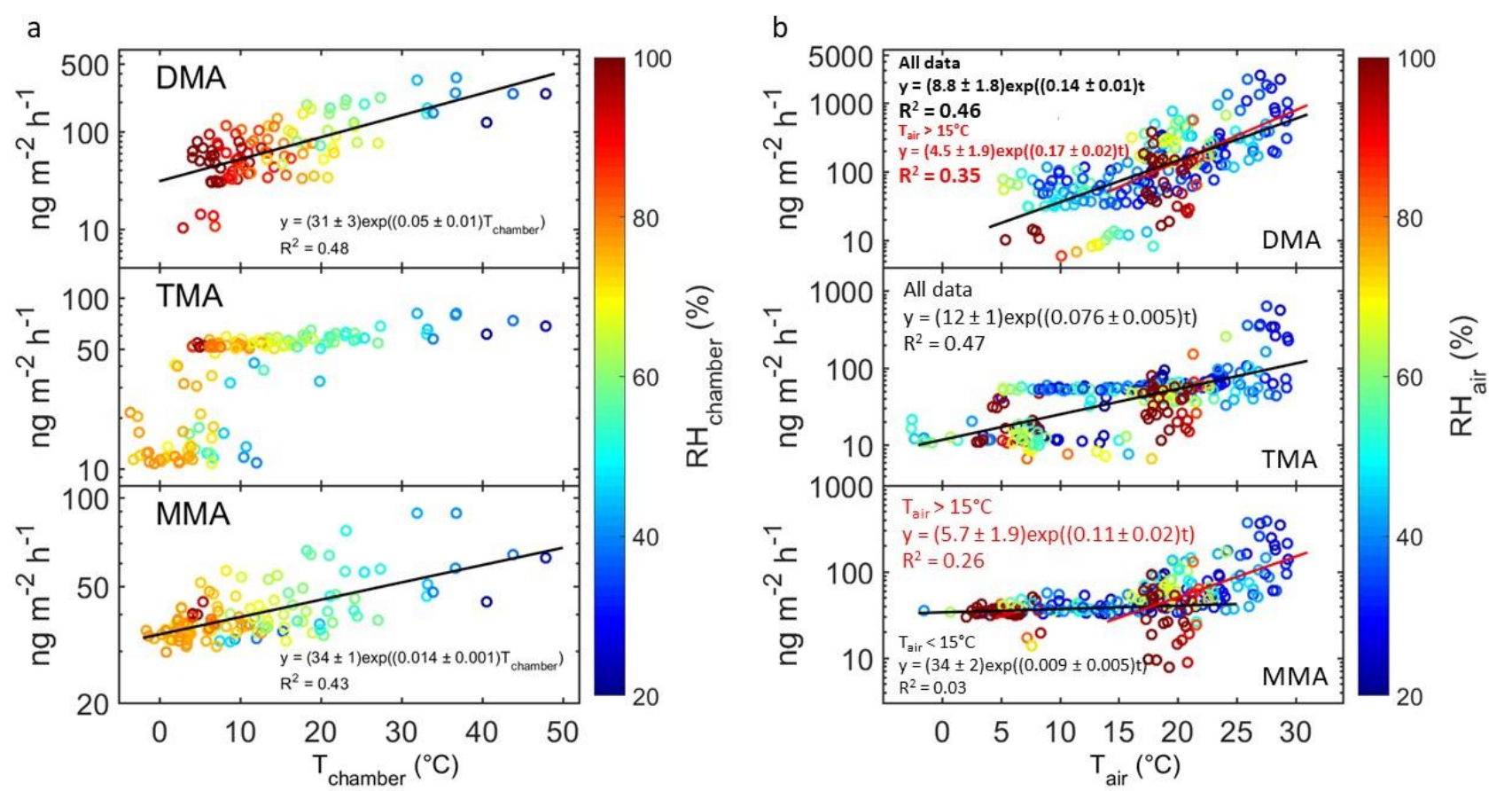

255 Figure 11: Emissions of three amines as a function of a) chamber temperature ( $\mathbf{T}_{\text {chamber }}$ ) and relative humidity (RH $\left.\mathbf{H}_{\text {chamber }}\right)$ and $\left.\mathbf{b}\right)$ outdoor air temperature $\left(\mathrm{T}_{\text {air }}\right)$ and relative humidity $\left(\mathrm{RH}_{\mathrm{air}}\right)$. Note that in a) there are data only until $28^{\text {th }}$ May, due to the malfunctioning of the RH sensor in the chamber, and the highest emissions were observed in July. Note also the different scales in both $x$ and $y$ axes in a) and $b$ ). 


\subsection{Effect of environmental parameters on emission rates}

In Figure 9, we can see that even though the maximum chamber temperatures were similar in both May and July, the emission rates and daily emission potentials were much higher in July. In May, the ambient air and soil surface were colder and the soil surface more humid than in July (Table 2). The colder and moister soil surface could explain the lower emissions in May. We compared emission rates of DMA, TMA and MMA to soil surface temperature $\left(\mathrm{T}_{\text {soil }}\right)$ and soil surface humidity (SH) (Fig. 12) and found that for higher $\mathrm{T}_{\text {soil }}$ and lower $\mathrm{SH}$, emission rates were higher. Such dependence was not found for the other amines and guanidine. The PAR values were also generally lower in May than in July.

The lowest amine emission rates were measured in April and September. Even though chamber, air and soil temperatures were lower and the soil moisture higher in April, the emissions were higher than in September. In April, our measurement chamber was located on melting snow, and this could have been an additional source of amines (Bigg, 2001). Generally, the emission rates were lower during nights, when the chamber, air and soil surface temperature were also lower.

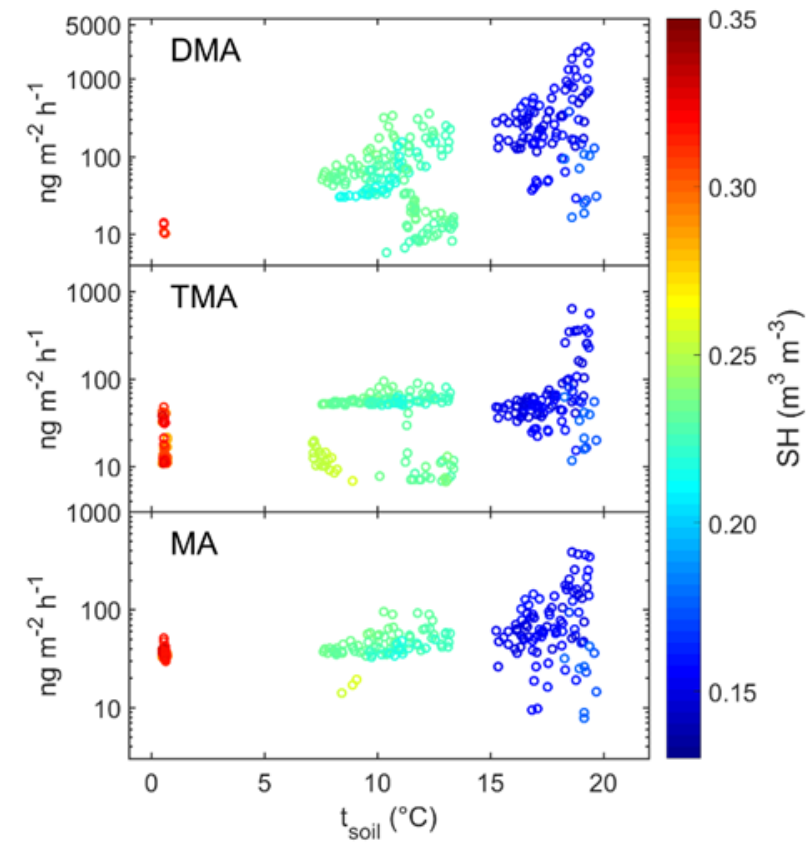

Figure 12: Emission rates of three amines in the chamber as a function of soil surface temperature $\left(t_{\text {soil }},{ }^{\circ} \mathrm{C}\right)$ and soil surface humidity (SH, $\left.\mathbf{m}^{3} \mathbf{m}^{-3}\right)$ (colour-coded). 
For guanidine, the highest emissions were measured in April during the snow-melting period and lowest in September. No clear explanation for the guanidine emission rate behaviour could be found from the chamber or environmental conditions.

Table 2. Average chamber and ambient conditions during the measurement periods.

\begin{tabular}{rllll}
\cline { 2 - 5 } & April & May & July & September \\
\hline $\mathrm{T}_{\text {Chamber }}\left({ }^{\circ} \mathrm{C}\right)$ & 4.0 & 18.4 & 24.3 & 12.5 \\
$\mathrm{RH}_{\text {Chamber }}(\%)$ & 83 & 79.10 & $\mathrm{NaN}$ & $\mathrm{NaN}$ \\
PAR $\left(\mu \mathrm{mol} \mathrm{m}^{-2} \mathrm{~s}^{-1}\right)$ & 160 & 240 & 292 & 102 \\
\hline $\mathrm{T}_{\text {Air }}\left({ }^{\circ} \mathrm{C}\right)$ & 5.8 & 15.1 & 22.1 & 11.5 \\
$\mathrm{~T}_{\text {Soil }}\left({ }^{\circ} \mathrm{C}\right)$ & 0.6 & 10.2 & 17.7 & 10.9 \\
Surface soil water & 0.30 & 0.23 & 0.16 & 0.24 \\
content $\left(\mathrm{m}^{3} \mathrm{~m}^{-3}\right)$ & & & & \\
\hline
\end{tabular}

\subsection{Error sources in the measurements}

Amines are difficult to detect under field conditions, because they are emitted in trace amounts and are highly reactive, so they can be part of chemical reactions and hence removed before they have been sampled and analysed. The recoveries of the chamber system for MMA, DMA and TMA were only 19\%, 29\% and 24\%, respectively; for guanidine we did not test it. The sampling line was also long (12 m), so losses to the walls were likely, even though we tried to minimize them by heating the inlet tubing. All this suggests, that the observed emission rates are potentially underestimating the true emission rates. The sampling time of MARGA-MS is $1 \mathrm{~h}$, so the results represent cumulative emissions over that time, but we chose the instrument because we could use it to separate various amines with the same mass. The potential challenges and limitations of MARGAMS were further discussed in our previous article (Hemmilä et al., 2018).

During the measurements, the temperatures inside the chamber commonly increase, especially if the sampling time is long and the chamber is in direct sunlight. For isoprenoids, increasing the temperature affects the volatility of the compounds and, hence, causes overestimations of their flux rates (Niinemets et al., 2011), which could also be the case for amines. Even though the $\mathrm{T}_{\text {chamber }}$ was usually very close to the ambient temperature (median difference being $1.4{ }^{\circ} \mathrm{C}$ and $66 \%$ of the time < $2{ }^{\circ} \mathrm{C}$ ), in May and July it was very high, especially in the afternoon, maximum difference being $29{ }^{\circ} \mathrm{C}$ and $21{ }^{\circ} \mathrm{C}$ in May and July, respectively. Obviously, the high temperature inside chamber may enhance amine emissions. However, the observed temperature dependency was in general clearly milder than in the case of isoprenoids (Guenther et al., 2012), so the effect of temperature increase is less pronounced in amines than in isoprenoids. Our emission potential estimates (Table 1) are also independent of temperature. The temperature range in our material is very wide (e.g. Fig. 11) which increases the reliability of emission potential estimation. In summary, even though our method likely overestimates the emission rates during summer afternoons, in general the effect of the losses is clearly stronger source of underestimation it is a source of overestimation. 
However, high-latitude microclimates have been observed temperatures as high as $15{ }^{\circ} \mathrm{C}$ above the ambient air temperature and reach values exceeding $30^{\circ} \mathrm{C}$ (Rinnan et al., 2014), but the phenomenon in boreal forests the phenomena is probably not as strong.

\section{Conclusions}

In situ amine and guanidine boreal forest floor emissions were measured at the SMEAR II station (Hyytiälä, Finland) in April, May, July and September 2018, about one week per month with time resolution of $1 \mathrm{~h}$. The recovery of emission measurements was tested semi-quantitatively for MMA, DMA and TMA, and the results were 19\%, 29\% and 24\%, respectively. Based on this experiment, the true emission rates are probably four times higher than those presented here.

MMA, DMA and TMA showed maximum emission rates in July, but the highest emission rates for guanidine were already measured in April when the snow was melting. The MMA, DMA and TMA emission rates showed wide diurnal variation, especially in July, with maxima in the afternoon. The DEA emission rates were generally low, showing clear diurnal cycle only in July.

The temperature dependence of emissions was examined; we found a clear correlation between the emission rates

315 and chamber temperature. Based on the assumption of delay between the chamber headspace temperature and soil temperature, and observed delay between emission rate and chamber headspace temperature, the soil temperature is likely the primary environmental control for the DMA and guanidine emissions. TMA showed similar pattern, but emission rates correlated with chamber temperature measured at the same time. The emissions from snow or vegetation rather than from soil could explain this. The emission rates of MMA, DMA, TMA and DEA were highest, when soil surface temperature was high and soil surface humidity low.

The laboratory work has shown that amines are a crucial component in aerosol formation, particularly through their capacity to stabilize acidic clusters during new particle formation (Kurtén et al., 2008; Petäjä et al., 2011; Almeida et al, 2013; Kulmala et al., 2013). Therefore, the results on the amine emissions from the boreal forest soil obtained in this study can be utilized e.g. in scaling up the climatic role of aerosol formation as the amines are important for the nanoparticle formation and their presence in the boreal environment can enhance aerosol formation and growth rates in this environment.

Data availability. The data sets can be accessed by contacting the corresponding author.

Acknowledgements. The research was supported by the Academy of Finland via the Academy Research Fellow project 330 (Academy of Finland, project 275608) and via Center of Excellence in Atmospheric Sciences (project no. 272041) and European Research Council via ATM-GTP 266 (742206). This research has also received funding from Academy of Finland (project no. 316114 \& 315203) as well as the Doctoral Programme in Atmospheric Sciences at the University of Helsinki. 


\section{References}

Aaltonen, H., Pumpanen, J., Pihlatie, M., Hakola, H., Hellén, H., Kulmala, L., Vesala, T., and Bäck, J.: Boreal pine forest floor biogenic volatile organic compound fluxes peak in early summer and autumn, Agr. Forest Meteorol., 151, 682-691, doi:10.1016/j.agrformet.2010.12.010, 2011.

Almeida, J., Schobesberger, S., Kurten, A., Ortega, I. K., Kupiainen-Maatta, O., Praplan, A. P., Adamov, A., Amorim, A., Bianchi, F., Breitenlechner, M., David, A., Dommen, J., Donahue, N. M., Downard, A., Dunne, E., Duplissy, J., Ehrhart, S., Flagan, R. C., Franchin, A., Guida, R., Hakala, J., Hansel, A.,Heinritzi, M., Henschel, H., Jokinen, T., Junninen, H., Kajos, M., Kangasluoma, J., Keskinen, H., Kupc, A., Kurten, T., Kvashin, A. N., Laaksonen, A., Lehtipalo, K., Leiminger, M., Leppa, J., Loukonen, V., Makhmutov, V., Mathot, S., McGrath, M. J., Nieminen, T., Olenius, T., Onnela, A., Petaja, T., Riccobono, F., Riipinen, I., Rissanen, M., Rondo, L., Ruuskanen, T., Santos, F. D., Sarnela, N., Schallhart, S., Schnitzhofer, R., Seinfeld, J. H., Simon, M., Sipila, M., Stozhkov, Y., Stratmann, F., Tome, A., Trostl, J., Tsagkogeorgas, G., Vaattovaara, P., Viisanen, Y., Virtanen, A., Vrtala, A., Wagner, P. E., Weingartner, E., Wex, H., Williamson, C., Wimmer, D., Ye, P., Yli-Juuti, T., Carslaw, K. S., Kulmala, M., Curtius, J., Baltensperger, U., Worsnop, D. R., Vehkamaki, H., and Kirkby, J.: Molecular Understanding of Sulphuric Acid-Amine Particle Nucleation in the Atmosphere, Nature, 502, 359-363, https://doi.org/10.1038/nature12663, 2013.

Angelino, S., Suess, D. T., and Prather, K. A.: Formation of aerosol particles from reactions of secondary and tertiary alkylamine: characterization by aerosol time-of-flight mass spectrometry, Env iron. Sci. Technol., 35, 3130-3138, 2001.

Bigg, E. K.: The aerosol in a boreal forest in spring, Tellus B, 53, 510-551, https://doi.org/10.3402/tellusb.v53i4.16626, 2001.

Ge, X., Wexler, A. S., and Clegg, S. L.: Atmospheric amines - Part I, A review, Atmos. Environ., 45, 524-546, https://doi.org/10.1016/j.atmosenv.2010.10.012, 2011.

Glasoe, W. A., Volz, K., Panta, B., Freshour, N., Bachman, R., Hanson, D.R., McMurry, P.H. and Jen, C.: Sulfuric acid nucleation: An experimental study of the effect of seven bases, J. Geophys. Res. Atmos., 120, 1933-1950, doi:10.1002/2014JD022730, 2015.

Guenther, AB., Jiang, X., Heald, CL., Sakulyanontvittaya, T., Duhl, T., Emmons, LK., Wang, X.: The Model of Emissions of Gases and Aerosols from Nature version 2.1 (MEGAN2.1): an extended and updated framework for modeling biogenic emissions, Geosci. Model Dev., 5(6), 1471-1492, https ://doi.org/10.5194/gmd-5-1471-2012, 2012.

Hari, P. and Kulmala, M.: Station for measuring ecosystematmosphere relations (SMEAR II), Boreal Environ. Res., 10, 315$322,2005$.

Hellén, H., Hakola, H., Pystynen, K.-H., Rinne, J., Haapanala, S.: C2-C10 hydrocarbon emissions from a boreal wetland and forest floor. Biogeosciences 3, 167-174, 2006.

Hemmilä, M., Hellén, H., Virkkula, A., Makkonen, U., Praplan, A. P., Kontkanen J., Ahonen, L., Kulmala, M. and Hakola, H.: Amines in boreal forest air at SMEAR II station in Finland, Atmos. Chem. Phys., 18, 6367-6380, https://doi.org/10.5194/acp-18-6367-2018, 2018. 
Ilvesniemi, H., Levula, J., Ojansuu, R., Kolari, P., Kulmala, L., Pumpanen, J., Launiainen, S., Vesala, T., and Nikinmaa, E.: Long-term measurements of the carbon balance of a boreal Scots pine dominated forest ecosystem, Boreal Environ. Res., $14,731-753,2009$.

IPCC: Climate Change 2013: The Physical Science Basis. Contribution of Working Group I to the Fifth Assessment Report of the Intergovernmental Panel on Climate Change, edited by: Stocker, T. F., Qin, D., Plattner, G.-K., Tignor, M., Allen, S. K., Boschung, J., Nauels, A., Xia, Y., Bex, V., and Midgley, P. M., Cambridge University Press, Cambridge, United Kingdom and New York, NY, USA, 1535 pp., 2013.

Junninen, H., Lauri, A., Keronen, P., Aalto, P., Hiltunen, V., Hari, P., and Kulmala, M.: Smart-SMEAR: on-line data exploration and visualization tool for SMEAR stations, Boreal Environ. Res., 14, 447-457, 2009.

Kieloaho, A.-J., Hellén, H., Hakola, H., Manninen, H. E., Nieminen, T., Kulmala, M., and Pihlatie, M.: Gas-phase alkylamines in a boreal Scots pine forest air, Atmos. Environ., 80, 369-377, https://doi.org/10.1016/j.atmosenv.2013.08.019, 2013.

Kieloaho, A.-J., Pihlatie, M., Launiainen, S., Kulmala, M., Riekkola, M.-L., Parshintsev, J., Mammarella, I., Vesala, T., and Heinonsalo, J.: Soil concentrations and soil-atmosphere exchange of alkylamines in a boreal Scots pine forest, Biogeosciences, 14, 1075-1091, https://doi.org/10.5194/bg-14-1075-2017, 2017.

Kulmala, M., Kontkanen, J., Junninen, H., Lehtipalo, K., Manninen, H. E., Nieminen, T., Petaja, T., Sipilä, M. J., Schobes-berger, S., Rantala, P., Franchin, A., Jokinen, T., Järvinen, P., Äijälä, M., Kangasluoma, J. P., Hakala, J. P., Aalto, P. P.,Paasonen, P., Mikkilä, J., Vanhanen, J., Aalto, J., Hakola, H.,Makkonen, U., Ruuskanen, T., Mauldin III, R., Duplissy, J.,Vehkamäki, H., Bäck, J., Kortelainen, A., Riipinen, I., Kurten,T. C., Johnston, M., Smith, J., Ehn, M. K., Mentel, T., Lehtinen,K., Laaksonen, A., Kerminen, V.-M., and Worsnop, D.: Directobservations of atmospheric nucleation, Science, 339, 943-946,https://doi.org/10.1126/science.1227385, 2013

Kurtén, T., Loukonen, V., Vehkamäki, H., and Kulmala, M.: Amines are likely to enhance neutral and ion-induced sulfuric acid-water nucleation in the atmosphere more effectively than ammonia, Atmos. Chem. Phys., 8, 4095-4103, https://doi.org/10.5194/acp-8-4095-2008, 2008.

Kurtén, T., Petäjä, T., Smith, J., Ortega, I. K., Sipilä, M., Junninen, H., Ehn, M., Vehkamäki, H., Mauldin, L., Worsnop, D. R., and Kulmala, M.: The effect of $\mathrm{H}_{2} \mathrm{SO}_{4}$ - amine clustering on chemical ionization mass spectrometry (CIMS) measurements of gas-phase sulfuric acid, Atmos. Chem. Phys., 11, 3007-3019, https://doi.org/10.5194/acp-11-3007$2011,2011$.

Makkonen, U., Virkkula, A., Mäntykenttä, J., Hakola, H., Keronen, P., Vakkari, V., and Aalto, P. P.: Semi-continuous gas and inorganic aerosol measurements at a Finnish urban site: comparisons with filters, nitrogen in aerosol and gas phases, and aerosol acidity, Atmos. Chem. Phys., 12, 5617-5631, https://doi.org/10.5194/acp-12-5617-2012, 2012.

Makkonen, U., Virkkula, A., Hellén, H., Hemmilä, M., Mäntykenttä, J., Äijälä, M., Ehn, M., Junninen, H., Keronen, P., Petäjä, T., Worsnop, D. R., Kulmala, M., and Hakola, H.: Semicontinuous gas and inorganic aerosol measurements at a boreal forest site: seasonal and diurnal cycles of $\mathrm{NH}_{3}, \mathrm{HONO}$ and $\mathrm{HNO}_{3}$, Boreal Environ. Res., 19 (suppl. B), 311-328, 2014 .

Marescau, B., Deshmukh, D. R., Kockx, M., Possemiers, I., Qureshi, I. A., Wiechert, P., De Deyn, P. P. Guanidino Compounds in Serum, Urine, Liver, Kidney, and Brain of Man and Some Ureotelic Animals, Metab. Clin. Exp., 41, 526-532, 1992. 
Myllys, N., Ponkkonen, T., Passananti, M., Elm, J., Vehkamäki, H., Olenius, T. Guanidine: A highly efficient stabilizer in atmospheric new-particle formation. J. Phys. Chem. A, 122, 4717-4729, doi:10.1021/acs.jpca.8b02507, 2018.

Mäki, M., Heinonsalo, J., Hellén, H., Bäck, J.: Contribution of understorey vegetation and soil processes to boreal forest isoprenoid exchange. Biogeosciences, 14, 1055-1073, https://doi.org/10.5194/bg-14-1055-2017, 2017.

Niinemets, Ü., Kuhn, U., Harley, P. C., Staudt, M., Arneth, A., Cescatti, A., Ciccioli, P., Copolovici, L., Geron, C., Guenther, A., Kesselmeier, J., Lerdau, M. T., Monson, R. K., and Peñuelas, J.: Estimations of isoprenoid emission capacity from enclosure studies: measurements, data processing, quality and standardized measurement protocols, Biogeosciences, 8 , 2209-2246, doi:10.5194/bg-8-2209-2011, 2011.

Paasonen, P., Olenius, T., Kupiainen, O., Kurtén, T., Petäjä, T., Birmili, W., Hamed, A., Hu, M., Huey, L. G., Plass-Duelmer, C., Smith, J. N., Wiedensohler, A., Loukonen, V., McGrath, M. J., Ortega, I. K., Laaksonen, A., Vehkamäki, H., Kerminen, V.-M., and Kulmala, M.: On the formation of sulphuric acid - amine clusters in varying atmospheric conditions and its influence on atmospheric new particle formation, Atmos. Chem. Phys., 12, 9113-9133, https://doi.org/10.5194/acp-12-9113-2012, 2012.

Petäjä, T., Sipilä, M., Paasonen, P., Nieminen, T., Kurtén, T., Stratmann, F., Vehkamäki, H., Berndt, T. and Kulmala, M.: Experimental observation of strongly bound dimers of sulphuric acid: application to nucleation in the atmosphere, Phys. Rev. Lett. 106, 228302, https://doi.org/10.1103/PhysRevLett.106.228302, 2011.

Rappert, S. and Müller, R.: Microbial degradation of selected odorous substances, Waste Manage., 25, 940-954, 2005.

Rinnan R., Steinke M., McGenity T. and Loreto F.: Plant volatiles inextreme terrestrial and marine environments, Plant, Cell \& Environ., 37, 1776-1789, doi: 10.1111/pce.12320, 2014.

Sarwar, G., Corsi, R. L., Kinney, K. A., Banks, J. A., Torres, V. M., and Schmidt, C.: Measurements of ammonia emissions from oak and pine forests and development of a non-industrial ammonia emissions inventory in Texas, Atmos. Environ., 39, 7137-7153, https://doi.org/10.1016/j.atmosenv.2005.08.016, 2005.

Sellegri, K., Hanke, M., Umann, B., Arnold, F., and Kulmala,M.: Measurements of organic gases during aerosol formationevents in the boreal forest atmosphere during QUEST, At-mos. Chem. Phys., 5, 373-384, https://doi.org/10.5194/acp-5-373-2005, 2005.

Sintermann, J., Schallhart, S., Kajos, M., Jocher, M., Bracher, A., Muenger, A., Johnson, D., Neftel, A. and Ruuskanen, T.: Trimethylamine emissions in animal husbandry, Biogeosciences, 11, 5073-5085, 10.5194/bg-11-5073-2014, 2014.

Sintermann, J. and Neftel, A.: Ideas and perspectives: on the emission of amines from terrestrial vegetation in the context of new atmospheric particle formation, Biogeosciences, 12, 3225-3240, doi:10.5194/bg-12-3225-2015, 2015.

Sipilä, M., Sarnela, N., Jokinen, T., Junninen, H., Hakala, J., Ris-sanen, M. P., Praplan, A., Simon, M., Kürten, A., Bianchi, F.,Dommen, J., Curtius, J., Petäjä, T., and Worsnop, D. R.: Bisul-fate - cluster based atmospheric pressure chemical ionizationmass spectrometer for high-sensitivity $(<100 \mathrm{ppqV})$ detectionof atmospheric dimethyl amine: proof-of-concept and first ambi-ent data from boreal forest, Atmos. Meas. Tech., 8, 40014011,https://doi.org/10.5194/amt-8-4001-2015, 2015. 
https://doi.org/10.5194/acp-2019-1157

Preprint. Discussion started: 14 January 2020

(C) Author(s) 2020. CC BY 4.0 License.

(c) (i)

ten Brink H.M., Otjes R., Jongejan P. \& Slanina S.: An instrument for semi-continuous monitoring of the sizedistribution of nitrate, ammonium, sulphate and chloride in aerosol. Atmos. Environ. 41, 2768-2779, 2007.

Van Pilsum, J. F., Martin, R. P., Kito, E., Hess, J. Determination of Creatine, Creatinine, Arginine, Guanidinoacetic Acid, Guanidine, and Methylguanidine in Biological Fluids, J. Biol. Chem., 222, 225-236, 1956.

440 Wang, M., Schurgers, G., Hellén, H., Lagergren, F., Holst, T.: Biogenic volatile organic compound emissions from a boreal forest floor, Bor. Env. Res., 23, 249-265, 2018.

Werdin-Pfisterer, N.R., Kielland, K, and Boone, R.D.; Soil amino acid composition across a boreal forest successional sequence, Soil Biol. Biochem., 41, 1210-1220, https://doi.org/10.1016/j.soilbio.2009.03.001, 2009.

Yan, F., Schubert, S., and Mengel, K.: Soil pH increase due to biological decarboxylation of organic anions, Soil Biol. Biochem., 28, 617-624, 1996.

Yu, H., McGraw, R., and Shan-Hu, L.: Effects of amines on formation of sub-3 nm particles and their subsequent growth, Geophys. Res. Lett. 39, L02807, doi:10.1029/2011GL050099, 2012. 


\section{Amine and guanidine emissions from a boreal forest floor Supplement}

Marja Hemmilä ${ }^{1}$, Ulla Makkonen ${ }^{1}$, Aki Virkkula ${ }^{1,2}$, Georgia Panagiotopoulou ${ }^{1}$, Juho Aalto ${ }^{2}$, Markku Kulmala ${ }^{2}$, Tuukka Petäjä ${ }^{2}$, Hannele Hakola ${ }^{1}$, Heidi Hellén ${ }^{1}$

${ }^{1}$ Finnish Meteorological Institute, P.O. Box 503, 00101 Helsinki, Finland

${ }^{2}$ Insitute for Atmospheric and Earth System Research / Physics, Faculty of Science, University of Helsinki, Finland

Correspondence to: Marja Hemmilä (marja.hemmila@helsinki.fi)

Table ST1. Line equations (y) for chamber temperature - emission rate -plots. For DMA and guanidine the the $\mathbf{R}^{2}$ values were better, when temperatures were moved 2 hours above. For DMA best fit was with exponential function, and for DMA and guanidine with linear function.

\begin{tabular}{lccccc}
\hline \multicolumn{2}{c}{ DMA } & TMA & \multicolumn{2}{c}{ Guanidine } \\
\hline Date & $\mathrm{y}$ & $\begin{array}{c}\mathrm{y} \text { without } \\
\text { temperature } \\
\text { move }\end{array}$ & $\mathrm{y}$ & $\mathrm{y}$ & $\begin{array}{c}\text { y without } \\
\text { temperature } \\
\text { move }\end{array}$ \\
\hline 24.5. & $47.665 \mathrm{e}^{0.0406 \mathrm{x}}$ & $52.02 \mathrm{e}^{0.0353 \mathrm{x}}$ & $0.8477 \mathrm{x}+43.052$ & $0.8796 \mathrm{x}+34.74$ & $0.7096 \mathrm{x}+37.599$ \\
25.5. & $40.286 \mathrm{e}^{0.0443 \mathrm{x}}$ & $44.375 \mathrm{e}^{0.0388 \mathrm{x}}$ & $0.6173 \mathrm{x}+46.863$ & $0.9563 \mathrm{x}+30.149$ & $0.9791 \mathrm{x}+29.266$ \\
26.5. & $39.267 \mathrm{e}^{0.0445 \mathrm{x}}$ & $45.138 \mathrm{e}^{0.0376 \mathrm{x}}$ & $0.5484 \mathrm{x}+46.319$ & $0.8956 \mathrm{x}+31.927$ & $0.6978 \mathrm{x}+35.948$ \\
27.5. & $25.91 \mathrm{e}^{0.0328 \mathrm{x}}$ & $31.361 \mathrm{e}^{0.0234 \mathrm{x}}$ & $1.4679 \mathrm{x}-7.7149$ & $1.4101 \mathrm{x}-0.652$ & $1.4651 \mathrm{x}-1.203$ \\
18.7. & $103.17 \mathrm{e}^{0.0596 \mathrm{x}}$ & $196.89 \mathrm{e}^{0.0371 \mathrm{x}}$ & $9.5789 \mathrm{x}-140.3$ & $1.0618 \mathrm{x}+18.844$ & $0.5088 \mathrm{x}+34.539$ \\
19.7. & $77.778 \mathrm{e}^{0.0624 \mathrm{x}}$ & $120.57 \mathrm{e}^{0.0454 \mathrm{x}}$ & $10.758 \mathrm{x}-154.65$ & $0.6528 \mathrm{x}+29.577$ & $0.5907 \mathrm{x}+31.155$ \\
20.7. & $84.551 \mathrm{e}^{0.0396 \mathrm{x}}$ & $89.87 \mathrm{e}^{0.0371 \mathrm{x}}$ & $4.7532 \mathrm{x}-40.486$ & $0.2202 \mathrm{x}+38.772$ & $0.2837 \mathrm{x}+37.317$ \\
21.7. & $177.1 \mathrm{e}^{-0.047 \mathrm{x}}$ & $92.12 \mathrm{e}^{-0.016 \mathrm{x}}$ & $-0.3408 \mathrm{x}+43.364$ & $-1.1165 \mathrm{x}+61.042$ & $-0.2303 \mathrm{x}+42.245$ \\
\hline
\end{tabular}



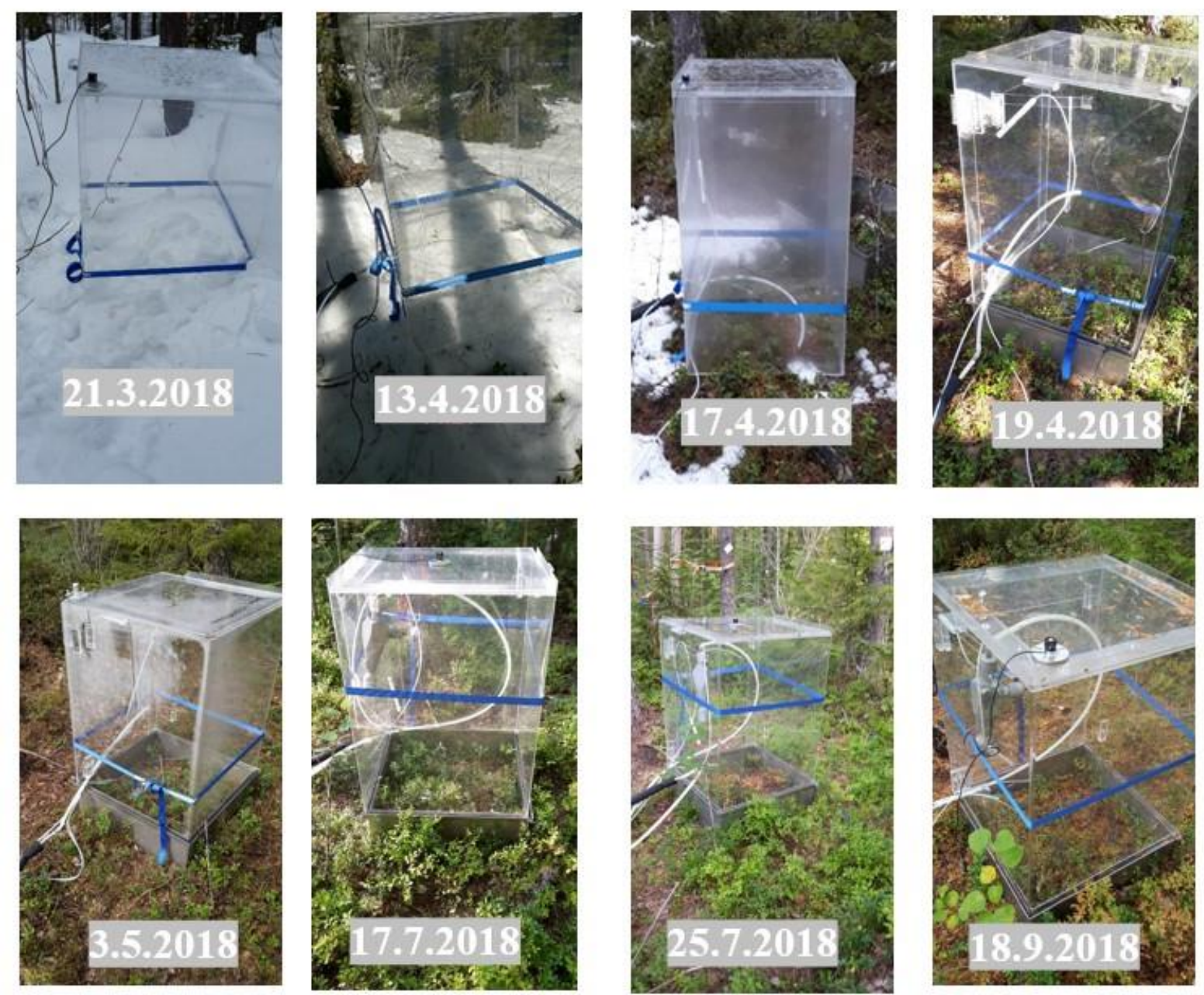

Figure S1. The chamber in different measurement periods. 